Prepared in cooperation with the U.S. Department of Energy, National Nuclear Security Administration Nevada Site Office, Office of Environmental Management under Interagency Agreement, DE-AI52-07NA28100

\title{
Digitally Available Interval-Specific Rock-Sample Data Compiled from Historical Records, Nevada Test Site and Vicinity, Nye County, Nevada
}

\section{Coarse alluvium}

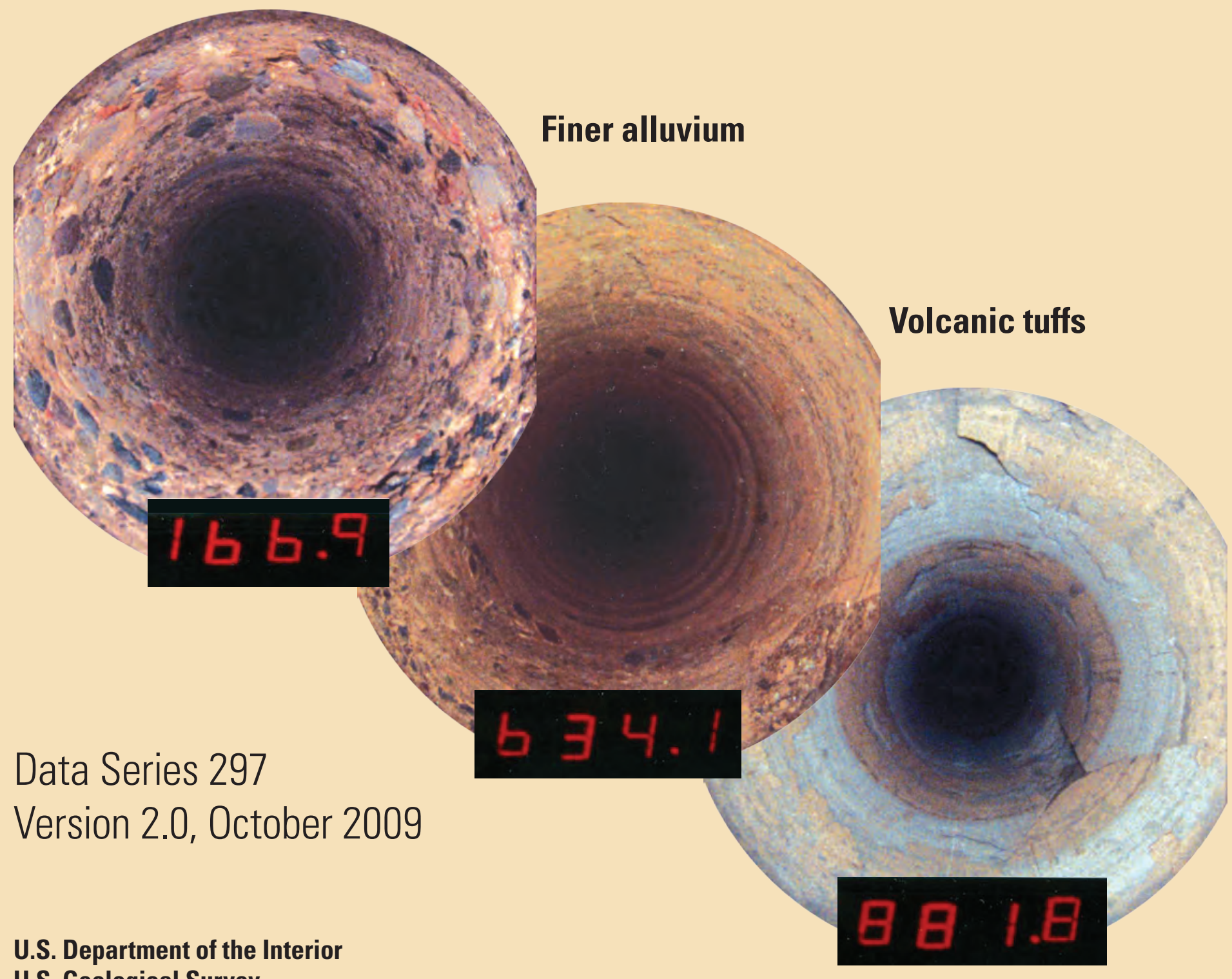




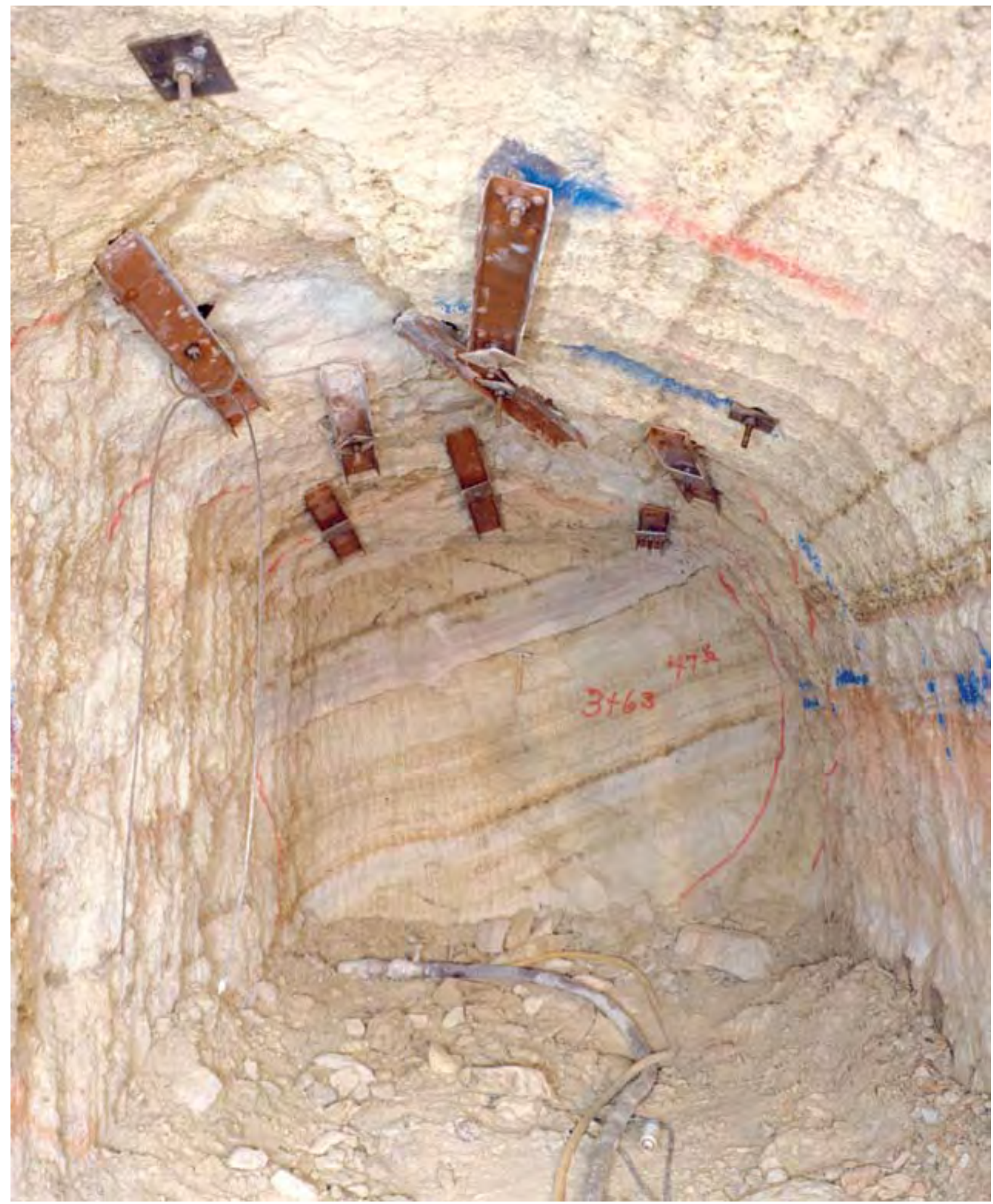

View inside reentry drift U -12n.10 A B shows volcanic tuffs from the Tertiary Tunnel Formation, $4 \mathrm{M}$ ember, beds 4C and 4D (Dean R. Townsend, Fenix and Scisson, Inc., written commun., October 5, 1976). The number 3+63 painted on the face indicates 363 feet from the portal opening. Photograph courtesy of Defense Threat Reduction Information A nalysis Center.

\section{Cover photograph}

Three downhole fish-eye camera views of emplacement hole U-2cs. View from 166.9 feet shows coarse alluvium. View from 634.1 feet shows coarse cobbly alluvium channels cut into finer alluvium. View from 881.8 feet shows a fault in the volcanic tuffs from the Tertiary Paintbrush Group. Photographs courtesy of Gayle A. Pawloski, Lawrence Livermore N ational Laboratory. 


\section{Digitally Available Interval-Specific Rock-Sample Data Compiled from Historical Records, Nevada Test Site and Vicinity, Nye County, Nevada}

By David B. Wood

Prepared in cooperation with the U.S. Department of Energy, National

Nuclear Security Administration Nevada Site Office, Office of Environmental

Management under Interagency Agreement, DE-Al52-07NA28100

Data Series 297

Version 2.0, October 2009 


\title{
U.S. Department of the Interior DIRK KEMPTHORNE, Secretary
}

\section{U.S. Geological Survey \\ Mark D. Myers, Director}

U.S. Geological Survey, Reston, Virginia: 2007

Revised: 2009

For product and ordering information:

World Wide Web: http://www.usgs.gov/pubprod

Telephone: 1-888-ASK-USGS

For more information on the USGS--the Federal source for science about the Earth, its natural and living resources, natural hazards, and the environment:

World Wide Web: http://www.usgs.gov

Telephone: 1-888-ASK-USGS

\begin{abstract}
Any use of trade, product, or firm names is for descriptive purposes only and does not imply endorsement by the U.S. Government.

Although this report is in the public domain, permission must be secured from the individual copyright owners to reproduce any copyrighted materials contained within this report.
\end{abstract}

Suggested citation:

Wood, D.B., 2007, Digitally available interval-specific rock-sample data compiled from historical records, Nevada Test Site and vicinity, Nye County, Nevada: U.S. Geological Survey Data Series 297, rev. 2.00, 96 p. 


\section{Contents}

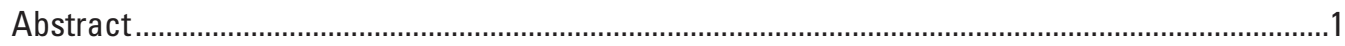

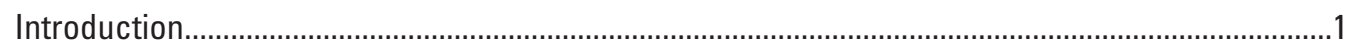

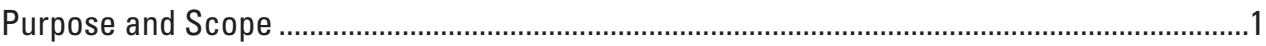

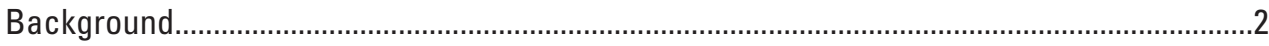

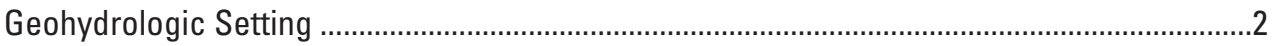

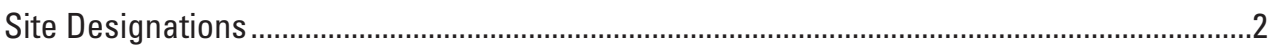

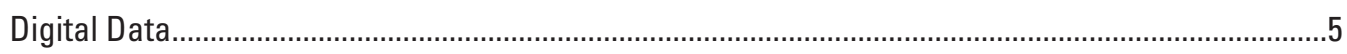

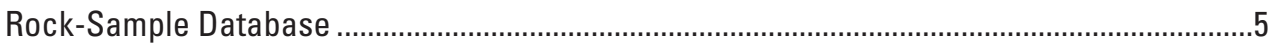

Lithologic-Description Database .......................................................................................

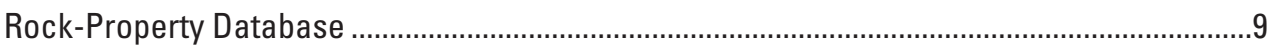

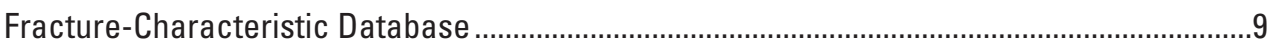

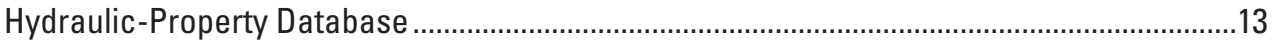

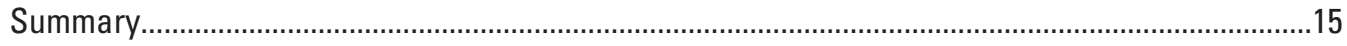

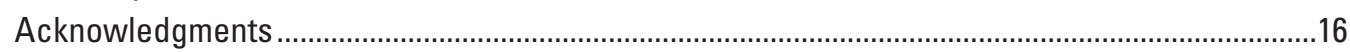

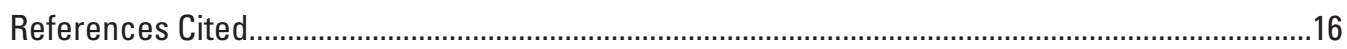

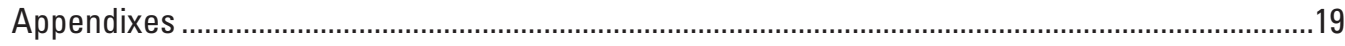

Appendix A. Rock-Sample Database, Nevada Test Site and Vicinity, Nye County, Nevada .......21

Appendix B. Lithologic-Description Database, Nevada Test Site and Vicinity, Nye

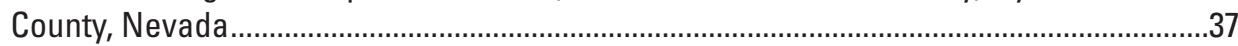

Appendix C. Rock-Property Database, Nevada Test Site and Vicinity, Nye County, Nevada .....51

Appendix D. Fracture-Characteristic Database, Nevada Test Site and Vicinity, Nye

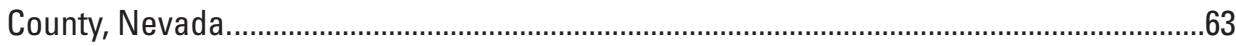

Appendix E. Hydraulic-Property Database, Nevada Test Site and Vicinity, Nye County,

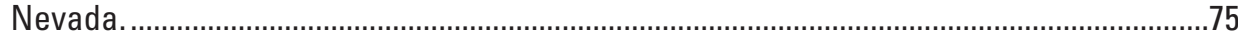

Appendix F. NTS USGS Databases, Nevada Test Site and Vicinity, Nye County, Nevada...........89 


\section{Figures}

Figure 1. Map showing location of Nevada Test Site and pertinent physiographic features, Nye County, Nevada

Figure 2. Map showing generalized distribution of rock types in vicinity of Nevada Test Site, Nye County, Nevada

Figure 3. Map showing areal distribution of rock-sample sites in vicinity of Nevada Test Site, Nye County, Nevada

Figure 4. Photographs showing examples of subsurface core and cuttings collected from exploratory holes at Nevada Test Site, Nye County, Nevada

Figure 5. Map showing areal distribution of lithologic-description sites in vicinity of Nevada Test Site, Nye County, Nevada

Figure 6. Profile showing example of generalized lithologic units in borehole ER-6-1, Nevada Test Site, Nye County, Nevada ....

Figure 7. Map showing areal distribution of rock-property sites in vicinity of Nevada Test Site, Nye County, Nevada

Figure 8. Profiles showing examples of subsurface rock-property data collected at Nevada Test Site, Nye County, Nevada

Figure 9. Map showing areal distribution of fracture-characteristic sites in vicinity of Nevada Test Site, Nye County, Nevada

Figure 10. Photograph showing example of subsurface fracture characteristics in vertical core hole $\mathrm{MH}-2$ in floor of emplacement drift U-12n.10 at 303.77 feet from portal opening, Nye County, Nevada...

Figure 11. Map showinf areal distribution of hydraulic-property sites in vicinity of Nevada Test Site, Nye County, Nevada

Figure 12. Graph showing example of subsurface hydraulic-property data collected at Nevada Test Site, Nye County, Nevada 


\section{Conversion Factors and Datums}

Inch/Pound to SI

\begin{tabular}{|c|c|c|}
\hline Multiply & By & To obtain \\
\hline \multicolumn{3}{|c|}{ Length } \\
\hline inch (in.) & 2.54 & centimeter $(\mathrm{cm})$ \\
\hline inch (in.) & 25.4 & millimeter (mm) \\
\hline foot (ft) & 0.3048 & meter (m) \\
\hline mile (mi) & 1.609 & kilometer (km) \\
\hline \multicolumn{3}{|c|}{ Area } \\
\hline square mile $\left(\mathrm{mi}^{2}\right)$ & 2.590 & square kilometer $\left(\mathrm{km}^{2}\right)$ \\
\hline \multicolumn{3}{|c|}{ Volume } \\
\hline barrel (bbl), (petroleum, 1 barrel =42 gal) & 0.1590 & cubic meter $\left(\mathrm{m}^{3}\right)$ \\
\hline gallon (gal) & 3.785 & liter $(L)$ \\
\hline gallon (gal) & 0.003785 & cubic meter $\left(\mathrm{m}^{3}\right)$ \\
\hline cubic foot $\mathrm{ft}^{3}$ ) & 0.02832 & cubic meter $\left(\mathrm{m}^{3}\right)$ \\
\hline \multicolumn{3}{|c|}{ Flow rate } \\
\hline foot per second (ft/s) & 0.3048 & meter per second (m/s) \\
\hline gallon per minute (gal/min) & 0.06309 & liter per second $(\mathrm{L} / \mathrm{S})$ \\
\hline gallon per day (gal/d) & 0.003785 & cubic meter per day $\left(\mathrm{m}^{3} / \mathrm{d}\right)$ \\
\hline \multicolumn{3}{|c|}{ Mass } \\
\hline ounce, avoirdupois (oz) & 28.35 & $\operatorname{gram}(\mathrm{g})$ \\
\hline pound, avoirdupois (Ib) & 0.4536 & kilogram (kg) \\
\hline \multicolumn{3}{|c|}{ Pressure } \\
\hline bar & 100 & kilopascal (kPa) \\
\hline kilo bar (kb) & 1,000 & kilopascal (kPa) \\
\hline pound per square inch (Ib/in²) & 6.895 & kilopascal (kPa) \\
\hline kilo pounds per square inch (kpsi) & 6.894757 & megapascal (M Pa) \\
\hline \multicolumn{3}{|c|}{ Density } \\
\hline pound per cubic foot $\left(\mathrm{Ib} / \mathrm{ft}^{3}\right)$ & 16.02 & kilogram per cubic meter $\left(\mathrm{kg} / \mathrm{m}^{3}\right)$ \\
\hline pound per cubic foot $\left(\mathrm{Ib} / \mathrm{ft}^{3}\right)$ & 0.01602 & gram per cubic centimeter $\left(\mathrm{g} / \mathrm{cm}^{3}\right)$ \\
\hline pound per cubic foot $\left(\mathrm{Ib} / \mathrm{ft}^{3}\right)$ & 0.01602 & megagram per cubic meter $\left(\mathrm{M} \mathrm{g} / \mathrm{m}^{3}\right)$ \\
\hline \multicolumn{3}{|c|}{ Specific capacity } \\
\hline $\begin{array}{l}\text { gallon per minute per foot } \\
[(\mathrm{gal} / \mathrm{min}) / \mathrm{ft})]\end{array}$ & 0.2070 & liter per second per meter $[(\mathrm{L} / \mathrm{s}) / \mathrm{m}]$ \\
\hline \multicolumn{3}{|c|}{ Electrical conductivity } \\
\hline micromhos per centimeter $(\mu \mathrm{mho} / \mathrm{cm})$ & 1 & M icrosiemens per centimeter $(\mu \mathrm{S} / \mathrm{cm})$ \\
\hline \multicolumn{3}{|c|}{ Velocity } \\
\hline foot per second (ft/s) & 0.0003048 & kilometer per second (km/s) \\
\hline
\end{tabular}




\section{Conversion Factors and Datums-Continued}

Temperature in degrees Celsius $\left({ }^{\circ} \mathrm{C}\right)$ may be converted to degrees Fahrenheit $\left({ }^{\circ} \mathrm{F}\right)$ as follows:

${ }^{\circ} \mathrm{F}=\left(1.8 \mathrm{x}^{\circ} \mathrm{C}\right)+32$.

Temperature in degrees Fahrenheit $\left({ }^{\circ} \mathrm{F}\right)$ may be converted to degrees Celsius $\left({ }^{\circ} \mathrm{C}\right)$ as follows:

${ }^{\circ} \mathrm{C}=\left({ }^{\circ} \mathrm{F}-32\right) / 1.8$.

Datums

Vertical coordinates are referenced to the North American Vertical Datum of 1929 (NGVD29); see altitude at portal opening, altitude of land surface, and reference point elevation in tables.

Horizontal coordinates are referenced to both the North American Datum of 1927 (NAD27) and 1983 (NAD83); see Nevada State Plane coordinates, latitude/longitude, decimal latitude/ longitude, and UTM coordinates in tables.

Altitude, as used in this report, refers to distance above the vertical datum. 


\title{
Digitally Available Interval-Specific Rock-Sample Data Compiled from Historical Records, Nevada Test Site and Vicinity, Nye County, Nevada
}

\author{
By David B. Wood
}

\begin{abstract}
B etween 1951 and 1992, 828 underground tests were conducted on the N evada Test Site, Nye County, N evada. Prior to and following these nuclear tests, holes were drilled and mined to collect rock samples. These samples are organized and stored by depth of borehole or drift at the U.S. Geological Survey Core Library and Data Center at M ercury, N evada, on the N evada Test Site. From these rock samples, rock properties were analyzed and interpreted and compiled into project files and in published reports that are maintained at the Core Library and at the U.S. G eological Survey office in Henderson, $\mathrm{N}$ evada. These rock-sample data include lithologic descriptions, physical and mechanical properties, and fracture characteristics. Hydraulic properties al so were compiled from holes completed in the water table. Rock samples are irreplaceable because pre-test, in-place conditions cannot be recreated and samples can not be recollected from the many holes destroyed by testing. Documenting these data in a published report will ensure availability for future investigators.
\end{abstract}

\section{Introduction}

R ock-sample data are available from both underground (boreholes, shafts, tunnels, and drifts) and surface (mostly outcrops and a few trenches) sites located on and around the N evada Test Site (NTS), Nye C ounty, N evada. These data include rock-sample interval locations, lithologic descriptions, physical and mechanical rock properties, fracture characteristics, and hydraulic properties. A cronyms and abbreviations in common usage at the NTS are described in the auxiliary 'nts_acr_abv' worksheets in the databases (appendixes A-F).

\section{Purpose and Scope}

This report documents rock samples and data derived from these samples in digital spreadsheets. Specifically, this report presents five databases (rock samples, lithologic descriptions, rock properties, fracture characteristics, and hydraulic properties). Data presented in these databases were obtained from rock samples and compiled from paper records contained in the historical files and from published reports located at the U.S. Geological Survey (USGS) Core Library and D ata Center at M ercury (on the NTS) and at the USGS office in Henderson, $\mathrm{N}$ evada.

The many logs and samples presented in this report represent a large investment over many years and are unique, in that in many cases, they cannot be acquired again. Pretest, in-place conditions, as well as conditions that existed prior and during nuclear testing can not be recreated and rock samples (and associated analysis and interpretations) from the many holes destroyed by testing can not be recollected. $M$ easurement techniques continuously evolve over time and the methods of interpretation are constantly being revised as new techniques become available. The application of these new methods often depends on the availability of the original subsurface data and the ability of individuals to understand both how these data were collected and how associated interpretations were developed. Documenting these data in a published report will ensure data availability for posterity. Furthermore, the condition of the original paper records is al ready poor and data are illegible for some records. The continuing deterioration of these records could preclude their availability to future investigators. A II subsurface data, regardless of program or application, needs to be archived for future use at the NTS. Only through publication and archiving, can these data be fully developed and utilized in making sound decisions concerning future activities at the NTS and protection of human heal th and safety. 


\section{Background}

The NTS (fig. 1) was established by the U nited States during the 1950 s as the primary continental proving ground for nuclear testing and peaceful applications of nuclear explosions (U.S. Congress, 1989). The site, which occupies about 1,375 $\mathrm{mi}^{2}$ of south-central N evada, was chosen by the A tomic Energy Commission (A EC, predecessor to the U.S. Department of Energy [DOE ]) primarily because of its remoteness from population centers and because the land was under military control (Fehner and Gosling, 2000). Since 1951, 928 tests have been conducted at the NTS. Of these tests, 828 were detonated underground (U.S. D epartment of Energy, 2000). In addition to the holes used for underground emplacement of nuclear weapons, many auxiliary holes were drilled and mined adjacent to the emplacement holes for collecting supplemental data. The databases presented in this report represent an accumulation of data from each of these holes.

Geologists, geophysicists, hydrologists, and other specialists have worked in cooperation with the DOE, National Nuclear Security A dministration, Nevada Site Office (and its predecessors) and the $N$ ational Laboratories to provide Earth science data since 1956 (P.P. Orkild, U.S. Geological Survey, written commun., 1987). The USGS and AEC agreed to cooperate in geologic, geophysical, and hydrologic investigations at the NTS under a memorandum of understanding (N O. AT (2902)474) dated June 1, 1957. A modification to the memorandum which incorporates the entire agreement (M odification N 0. 3, Schedule 1 to A ppendix A, page 3, item 4), dated A pril 3, 1959 states:

\footnotetext{
"Operation of a Field and Geological Data Repository and Core Library. Maintain field records at a central location at NTS which will have a recurring use for reference purposes. It is intended that the Geological Survey have on file representative logs of significant excavations, and establish and maintain core libraries (exclusive of radiochemical cores) in accordance with mutually agreed USGS-Commission rules and procedures."
}

The U SGS Core Library and Data Center was established in temporary quarters during 1959 at $\mathrm{M}$ ercury, N evada, and a permanent facility was built during the late 1960s (G.L. Dixon, U.S. Geological Survey, written commun., 1983). B ecause the USGS was designated as the caretaker of the rock samples, personnel from the $\mathrm{N}$ ational $\mathrm{L}$ aboratories as well as DOE and Department of Defense (DOD) contractors were continually accessing rock samples at the Core Library. This resulted in the USGS amassing paper copies of many of the preliminary results of the rock-sample analyses and interpretations as well as internal and published reports resulting from this work.

\section{Geohydrologic Setting}

The NTS is entirely within the Great $B$ asin region of the $B$ asin and $R$ ange physiographic province. The region is characterized by mountain ranges with a general northsouth orientation separated by basins (valleys) that are filled by accumulations of unconsolidated to partly consolidated sedimentary deposits and underlain by consolidated rocks that al so form the surrounding ranges (Stewart, 1980). The unconsolidated rocks at the NTS consist of basin fill and volcanic and sedimentary rocks. Consolidated rocks consist of volcanic, metamorphic and intrusive, siliciclastic, and carbonate rocks. The general ized distribution of rock types in the vicinity of the NTS is shown in figure 2 .

The stratigraphic nomenclature at the NTS has evolved over time. The USGS conducted surface-mapping field work between 1958 and 1964 that resulted in the publication of thirty-four 7.5-minute geologic maps (Byers and others, 1989). The stratigraphy and lithology has been continually refined by investigators from various organizations (including DOE/DOD subcontractors, the National Laboratories, and USGS) by inspection of rock samples collected from holes drilled and mined at the NTS and vicinity. This has resulted in many informal units in common usage at the NTS. Volcanic rocks are summarized in Byers and others (1976) and Sawyer and others (1994). Carbonate rocks are summarized in Cole and Cashman (1999). Stratigraphic units are lumped into hydrogeologic units and discussed in IT Corporation (1996a, 1996b), Faunt and others (2004), and Sweetkind and others (2004).

The hydrologic setting of the NTS is similar to that of most of the Basin and Range province. It is characterized by localized aquifers within the alluvial deposits in the eastern, central, and southern parts. R egional aquifers are mostly within complexly folded and faulted limestones and dolomites that underlie the localized aquifers in the eastern and southern parts, but also are within fractured volcanic rocks in the western part of the NTS. M uch of the ground-water flow is interbasin; that is, flow is not strictly controlled by the surface topography that defines surface-water drainage basins (Blankennagel and Weir, 1973; Winograd and Thordarson, 1975; Laczniak and others, 1996; Slate and others, 2000; Potter and others, 2002; Workman and others, 2002).

\section{Site Designations}

R ock-sample sites are identified primarily by the USGS NTS unique number and secondarily by the NTS area (the NTS is comprised of 26 administrative areas [fig. 1]), a Redbook hole number, and USGS National Water Information System (N WIS) site identification number (U.S. Geological Survey, 2005). A unique number is necessary because spatial $(X-Y)$ coordinates are currently not available for some sites. Site designations are described in the tables listed in the appendixes of this report. 


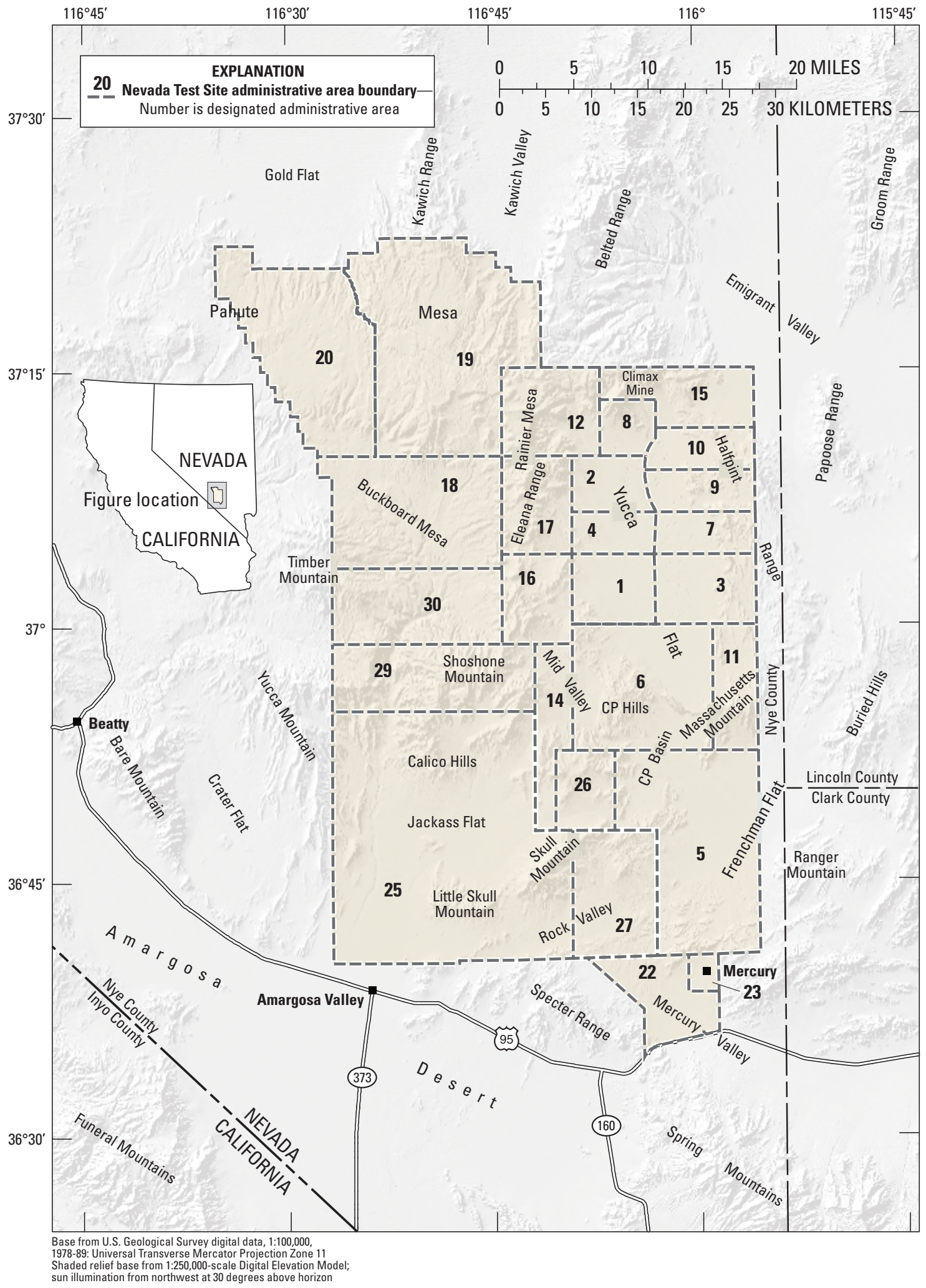

Figure 1. Location of Nevada Test Site and pertinent physiographic features, Nye County, Nevada. 


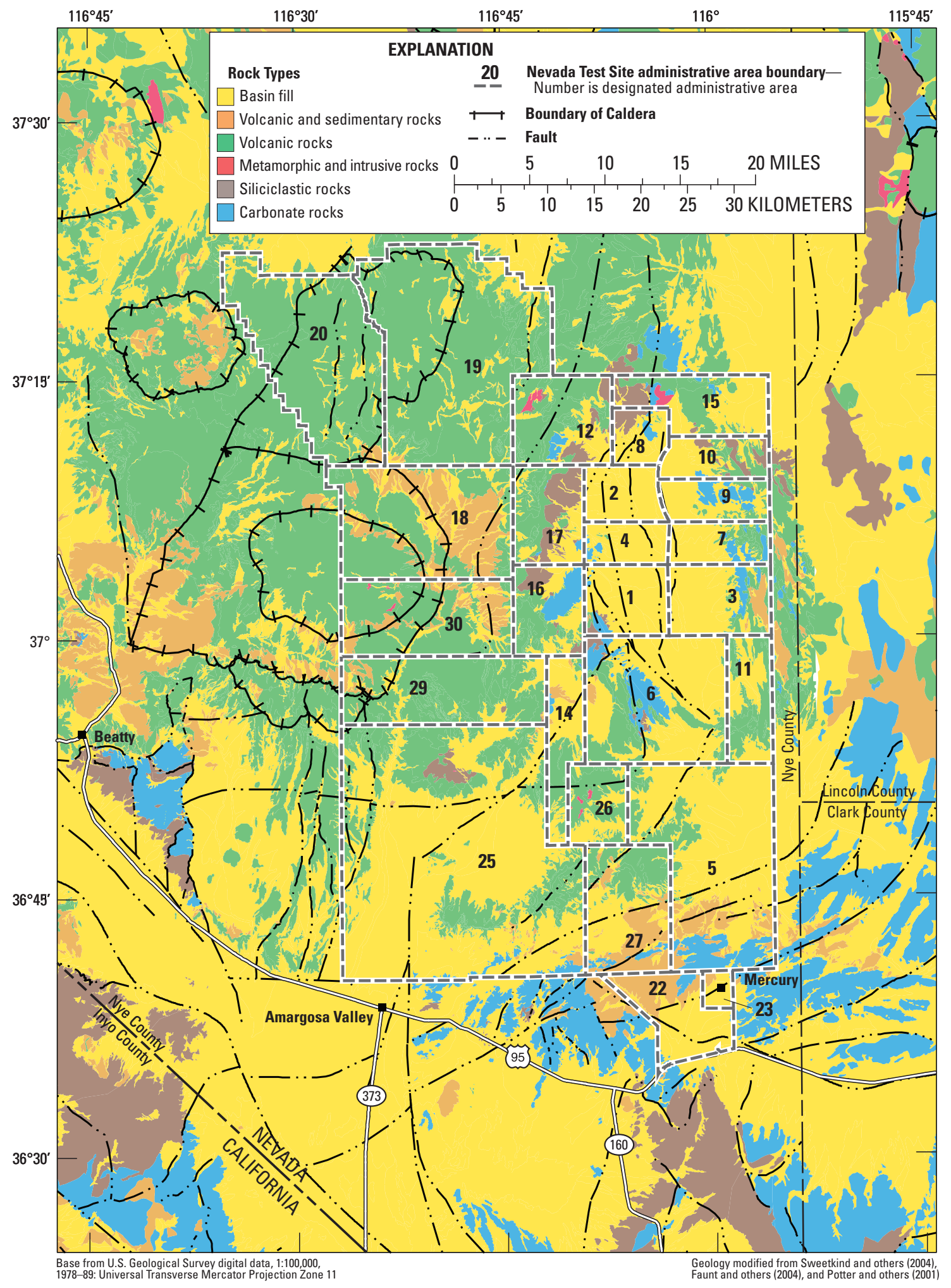

Figure 2. Generalized distribution of rock types in vicinity of Nevada Test Site, Nye County, Nevada. 


\section{Digital Data}

The USG S compiled both M icrosoft ${ }^{\circ}$ Excel spreadsheets and $\mathrm{M}$ icrosoft ${ }^{\circ} \mathrm{A}$ ccess tables, by depth interval, of available rock-sample, thin-section (prepared from rock samples), and aquifer-test data stored at the USGS Core Library and Data Center in M ercury and the USGS office in Henderson, $\mathrm{N}$ evada. These digital spreadsheets and tables are the RockSample database, Lithologic-Description database, RockProperty database, Fracture-C haracteristic database, and Hydraulic-Property database. Records were compiled for vertical (boreholes and shafts) and horizontal (tunnels and drifts) underground sites and for surface locations (mostly outcrops and a few trenches). Rock-sample locations were inventoried by personnel stationed at the M ercury facility. Rock-sample records were compiled by personnel stationed at the Henderson office from paper copies of records contained in the historical files stored at the M ercury and Henderson locations and from paper copies of published reports. Thinsection compilations were provided in el ectronic format. A small percentage of lithologic descriptions, rock properties, and fracture characteristics were provided in electronic format towards the end of the study.

\section{Rock-Sample Database}

The USG S catal ogued interval-specific locations for rock samples and thin sections (prepared from rock samples) collected from both underground and surface sites located on and around the NTS (fig. 3). The Rock-Sample database presents locations of rock samples and thin sections collected by DOE/DOD contracting organizations, the National Laboratories, and USGS and stored at the USGS Core Library. The database is both a digital spreadsheet (appendix A) and table (appendix F). Field-content headings are described in table A 1. L ocations of all rock samples and thin sections stored at the M ercury facility have been compiled. However, rock samples stored at the USGS Yucca M ountain Program (Y M P) sample management facility in NTS A rea 25 (fig. 1) are part of another program and have not been included in this compilation.
A core sample collected from exploratory hole UE-20f and a cuttings sample collected from exploratory hole UE-14b are used to show examples of rock-sample data at the NTS. Hole UE-20f is the deepest hole drilled at the NTS and the core sample collected from the bottom (13,670-13,686 foot) interval of this hole shows an example of welded volcanic tuff. Wooden blocks indicate sections of core removed from the USGS Core Library (fig. 4A). The cuttings sample collected from the 1,120- to 2,160-ft interval of exploratory hole UE-14b shows an example of variations in welded volcanic tuffs (fig. $4 B$ ).

\section{Lithologic-Description Database}

The USGS compiled interval-specific records of lithologic descriptions for both underground and surface sites located on and around the N TS (fig. 5). The LithologicDescription database presents lithologies interpreted and re-interpreted from rock samples and geophysical and video logs in boreholes and shafts and mapped inside tunnels and drifts by investigators from DOE/DOD contracting organizations, the N ational Laboratories, and USGS. The database is both a digital spreadsheet (appendix B) and table (appendix F). Field-content headings are described in table B 1 . $L$ ithologic descriptions have been compiled for sites located in F renchman, Jackass and Yucca Flats, and on B uckboard, Pahute, and Rainier M esas, and parts of the A margosa Desert near the NTS (fig. 1).

The lithologic-description data for borehole E R-6-1 are used to show a graphical example of generalized lithologic units at the NTS (fig. 6). The general units penetrated in this hole are alluvium, nonwelded to welded and bedded tuff, dolomite, and quartzite. The lithology was interpreted by Sigmund L. D rellack, J r. and L ance B. Prothro from National Security Technologies, LLC and by Robert L. M cCall from Stoller-N avarro J oint Venture. 


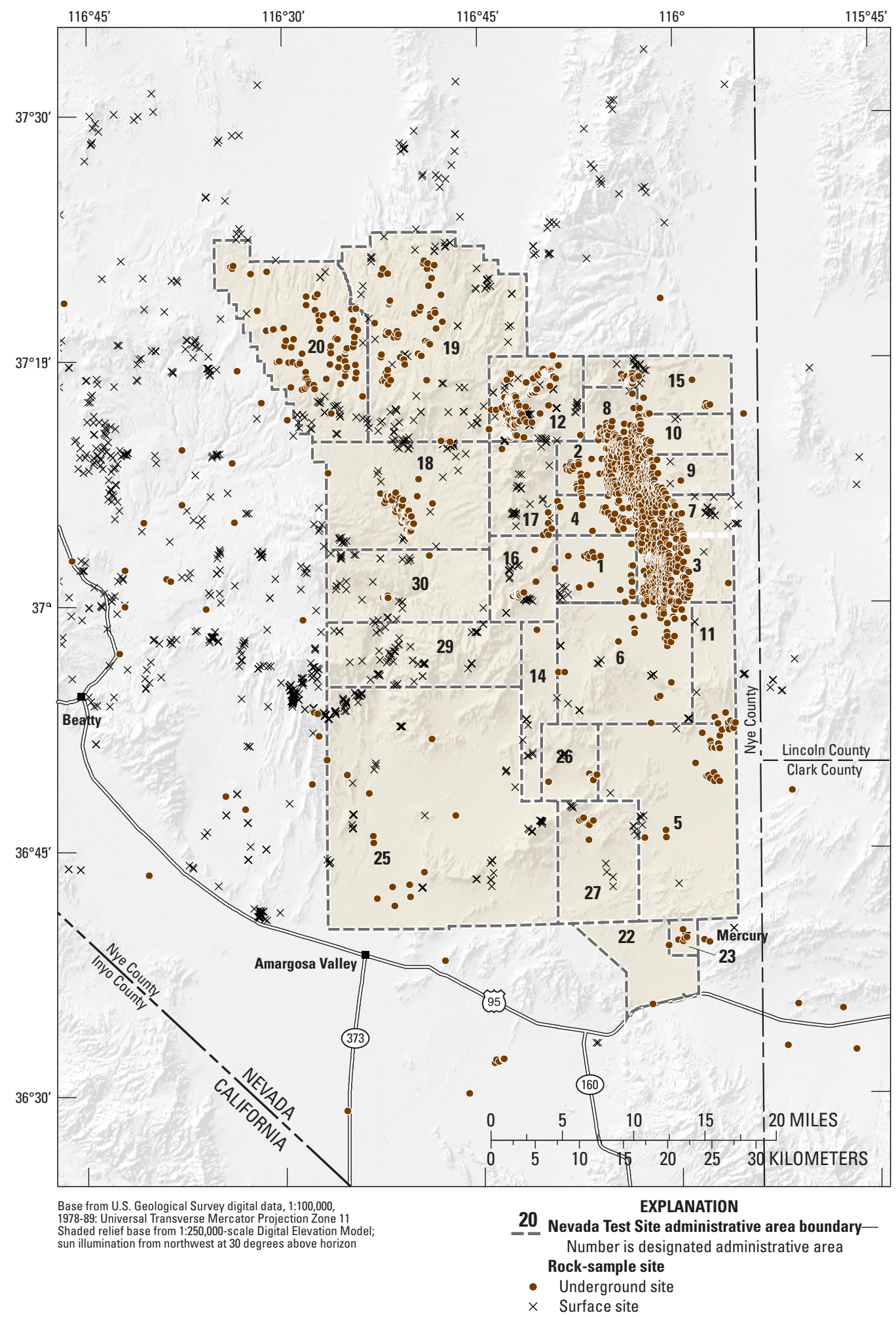

Figure 3. Areal distribution of rock-sample sites in vicinity of Nevada Test Site, Nye County, Nevada. 


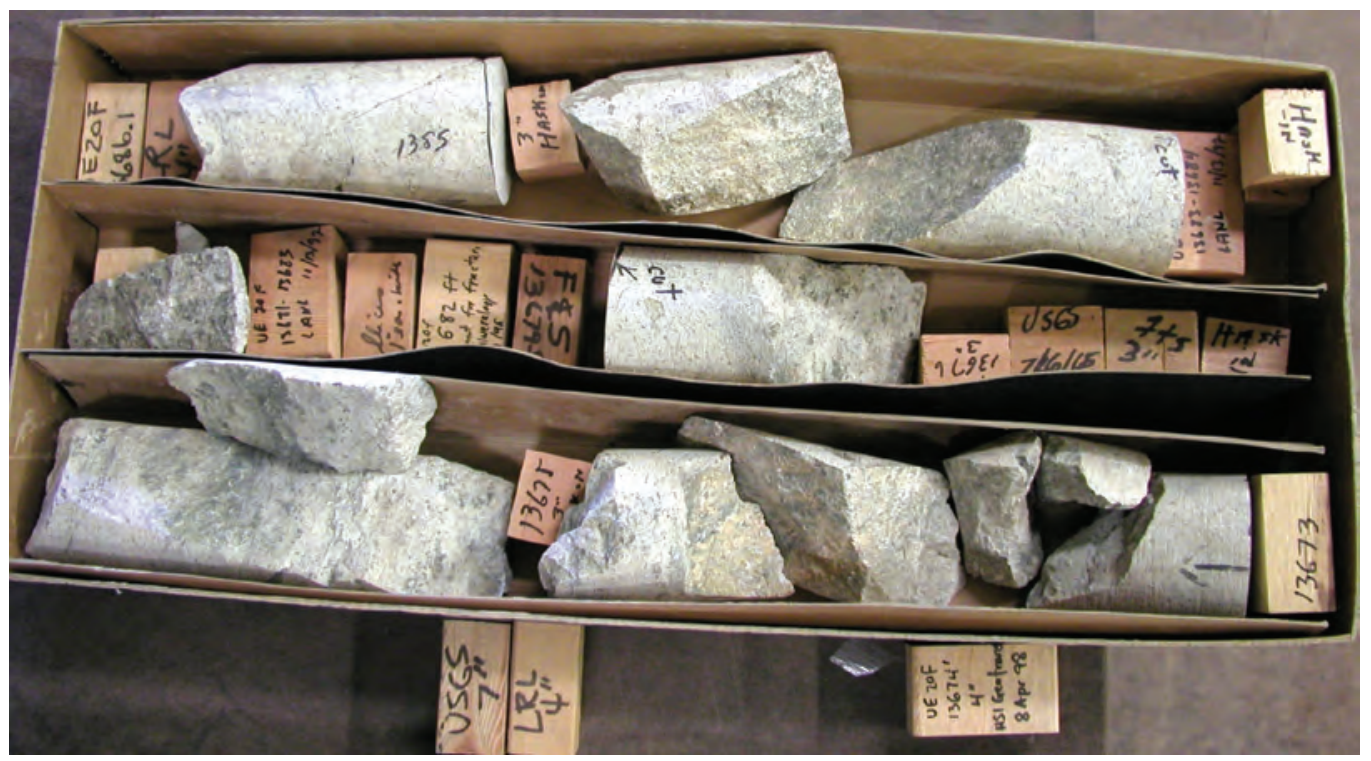

A. Subsurface core collected from bottom interval of exploratory hole UE-20f; deepest hole drilled at Nevada Test Site. Core sample shows welded volcanic tuff from 13,670- to 13,686-foot interval. Wooden blocks indicate sections of core removed from U.S. Geological Survey Core Library. Photograph taken by Jerry Magner, U.S. Geological Survey.

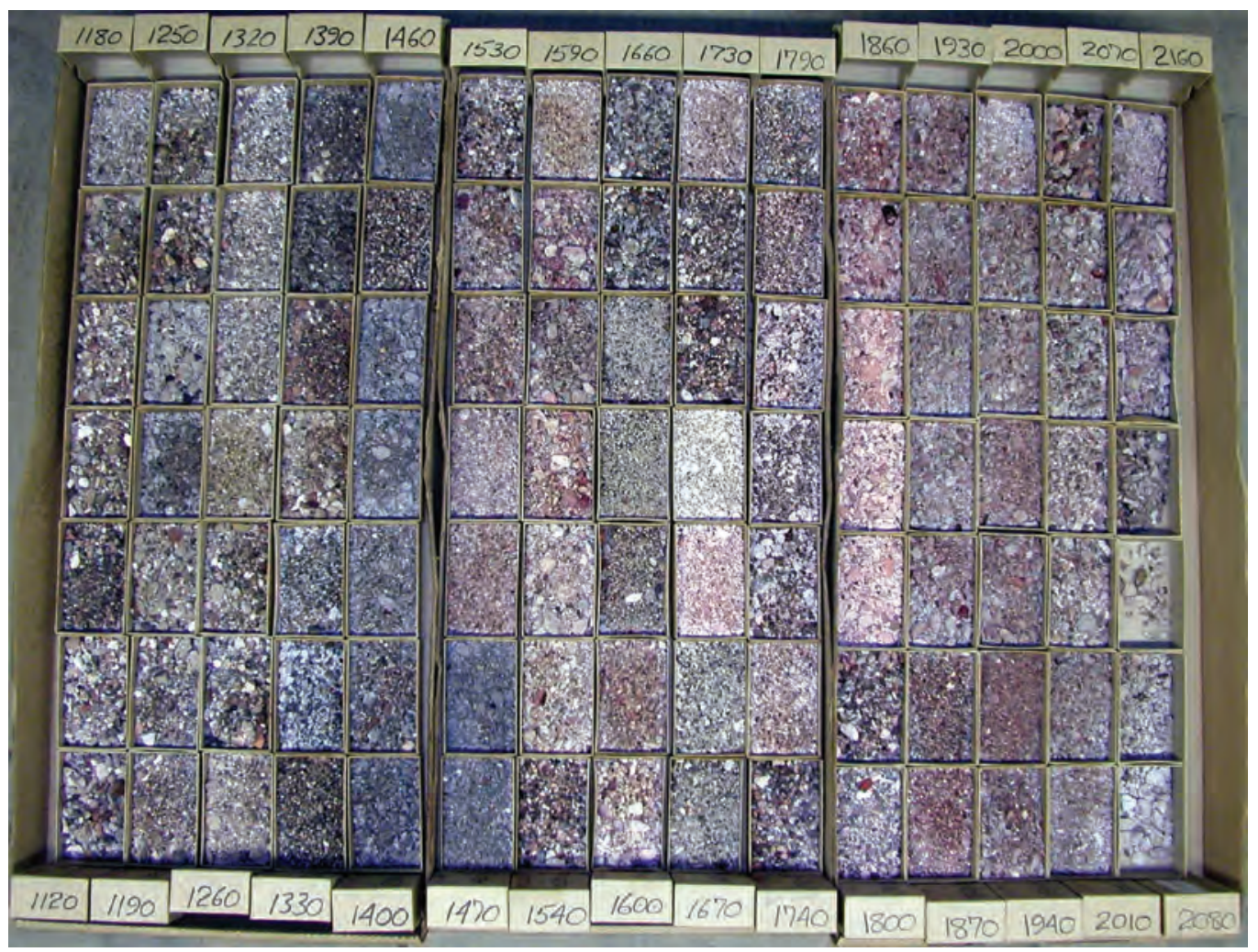

B. Subsurface cuttings collected from exploratory hole UE-14b. Cuttings sample shows variations in welded volcanic tuffs from 1,120- to 2,160-foot interval. Photograph taken by Jerry Magner, U.S. Geological Survey.

Figure 4. Examples of subsurface core and cuttings collected from exploratory holes at Nevada Test Site, Nye County, Nevada. 


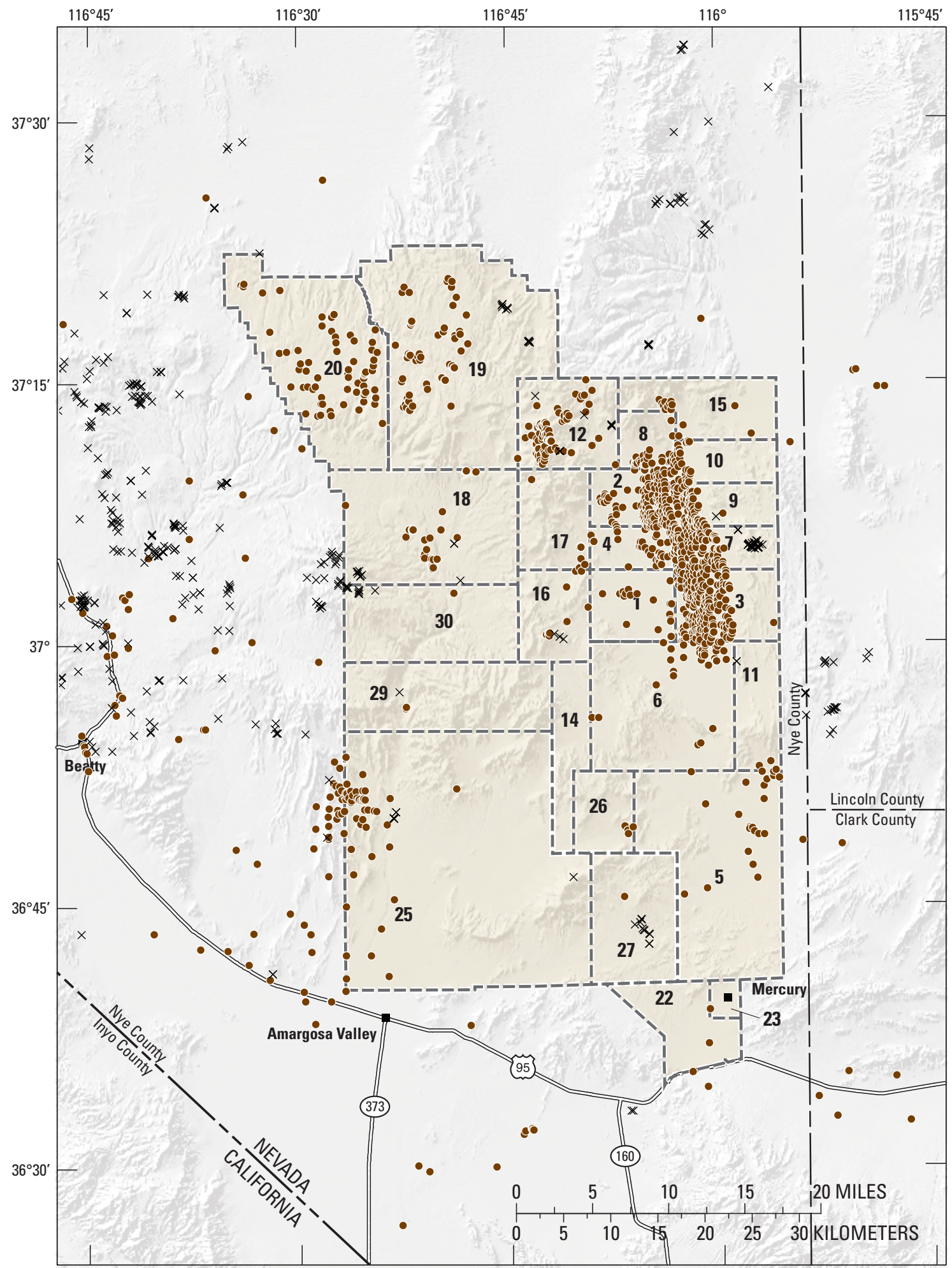

Base from U.S. Geological Survey digital data, 1:100,000, 1978-89: Universal Transverse Mercator Projection Zone 11 Shaded relief base from 1:250,000-scale Digital Elevation Mode

20 Nevada Test Site administrative area boundaryNumber is designated administrative area

Lithologic-description site

- Underground site

$\times$ Surface site

Figure 5. Areal distribution of lithologic-description sites in vicinity of Nevada Test Site, Nye County, Nevada. 


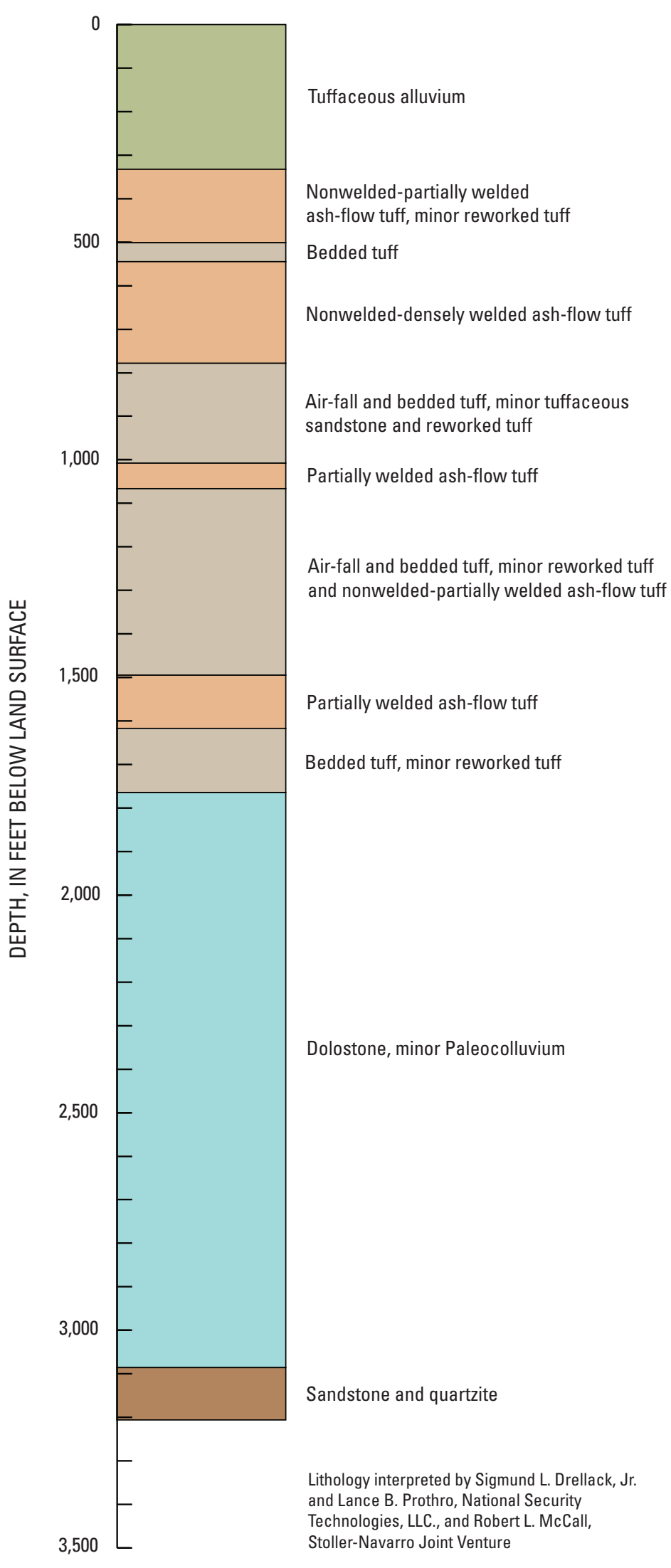

\section{Rock-Property Database}

The USGS compiled interval-specific records of rock-property data for both underground and surface sites located on and around the NTS (fig. 7). The RockProperty database presents physical and mechanical properties analyzed from rock samples by investigators from DOE/DOD contracting organizations, the National L aboratories, and USGS. The database is both a digital spreadsheet (appendix C) and table (appendix F). Fieldcontent headings are described in table $\mathrm{C} 1$. Physical and mechanical rock properties have been compiled for sites located in F renchman and Yucca Flats and on Buckboard, Pahute, and Rainier M esas (fig. 1). Physical and mechanical rock properties are available but have not been compiled for holes located in J ackass Flat (fig. 1).

Samples collected from exploratory hole U $-4 d$ Ex. \#1 and analyses contained in L awrence Livermore $N$ ational L aboratory project files are used to show examples of rock-property data at the NTS. Depth profiles are shown for grain density, wet (natural-state) bulk density, and wet water content by weight from exploratory hole U-4d Ex. \#1 (fig. 8).

\section{Fracture-Characteristic Database}

The USGS compiled interval-specific records of fracture-characteristic data for both underground and surface sites located on and around the NTS (fig. 9). The Fracture-Characteristic database presents locations of fractures interpreted from rock samples and geophysical and video logs in boreholes and shafts and mapped inside tunnels and drifts by investigators from DOE/DOD contracting organizations, the $\mathrm{N}$ ational L aboratories, and USGS. The database is both a digital spreadsheet (appendix D) and table (appendix F). Fieldcontent headings are described in table D 1. F racture characteristics have been compiled for sites located in Frenchman and Yucca Flats, and on B uckboard, Pahute, and Rainier M esas (fig. 1). F racture characteristics are available but have not been compiled for holes located in J ackass Flat (fig. 1).

A core sample collected from the core hole $\mathrm{M} \mathrm{H}-2$, drilled vertically in the invert (floor) of emplacement drift U $-12 n .10$ at $303.77 \mathrm{ft}$ from the portal opening, is used to show an example of fracture-characteristic data at the NTS. Slickensides and black staining on fracture surfaces are indicated at $79 \mathrm{ft}$ (fig. 10).

Figure 6. Example of generalized lithologic units in borehole ER-6-1, Nevada Test Site, Nye County, Nevada. 


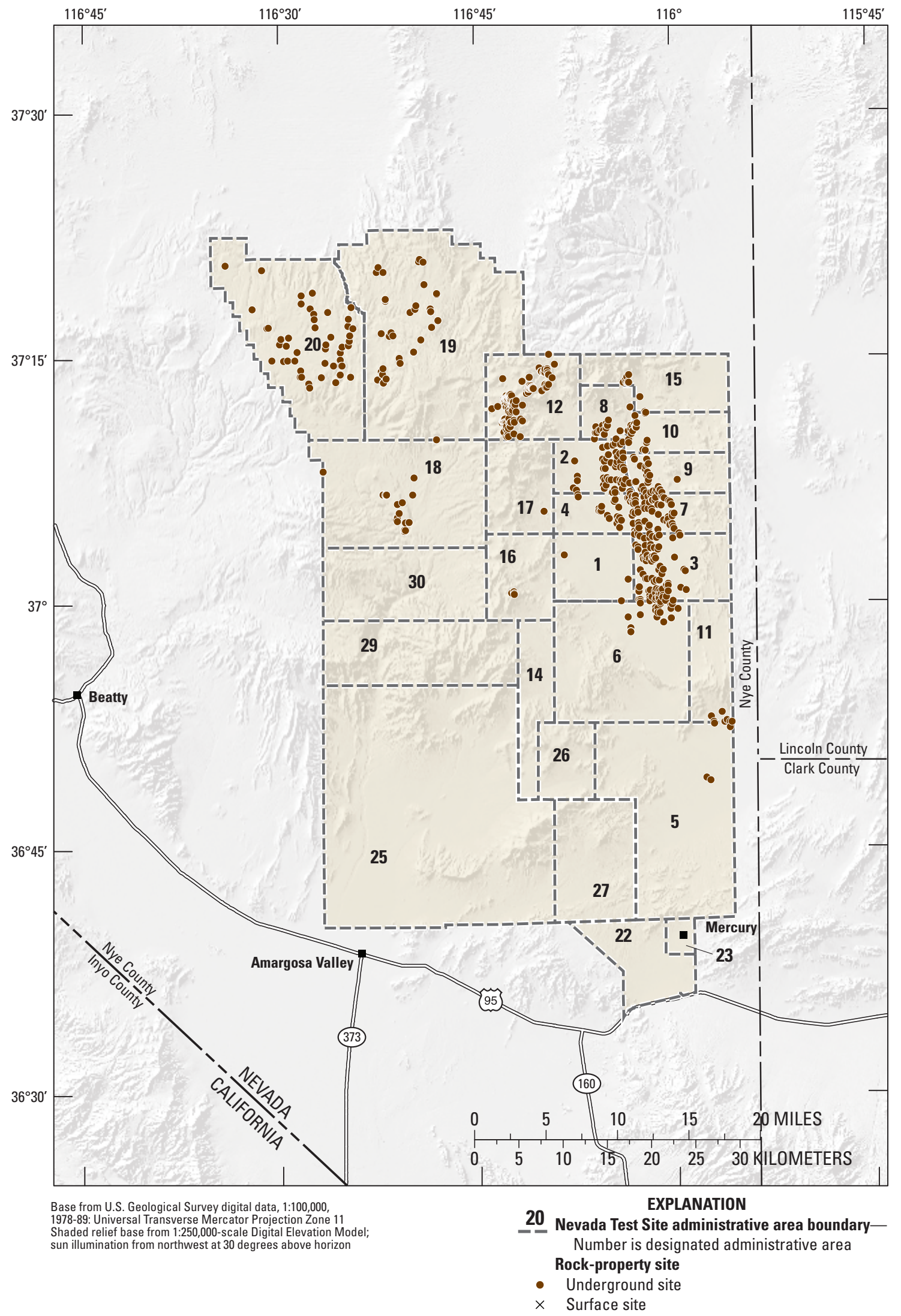

Figure 7. Areal distribution of rock-property sites in vicinity of Nevada Test Site, Nye County, Nevada. 

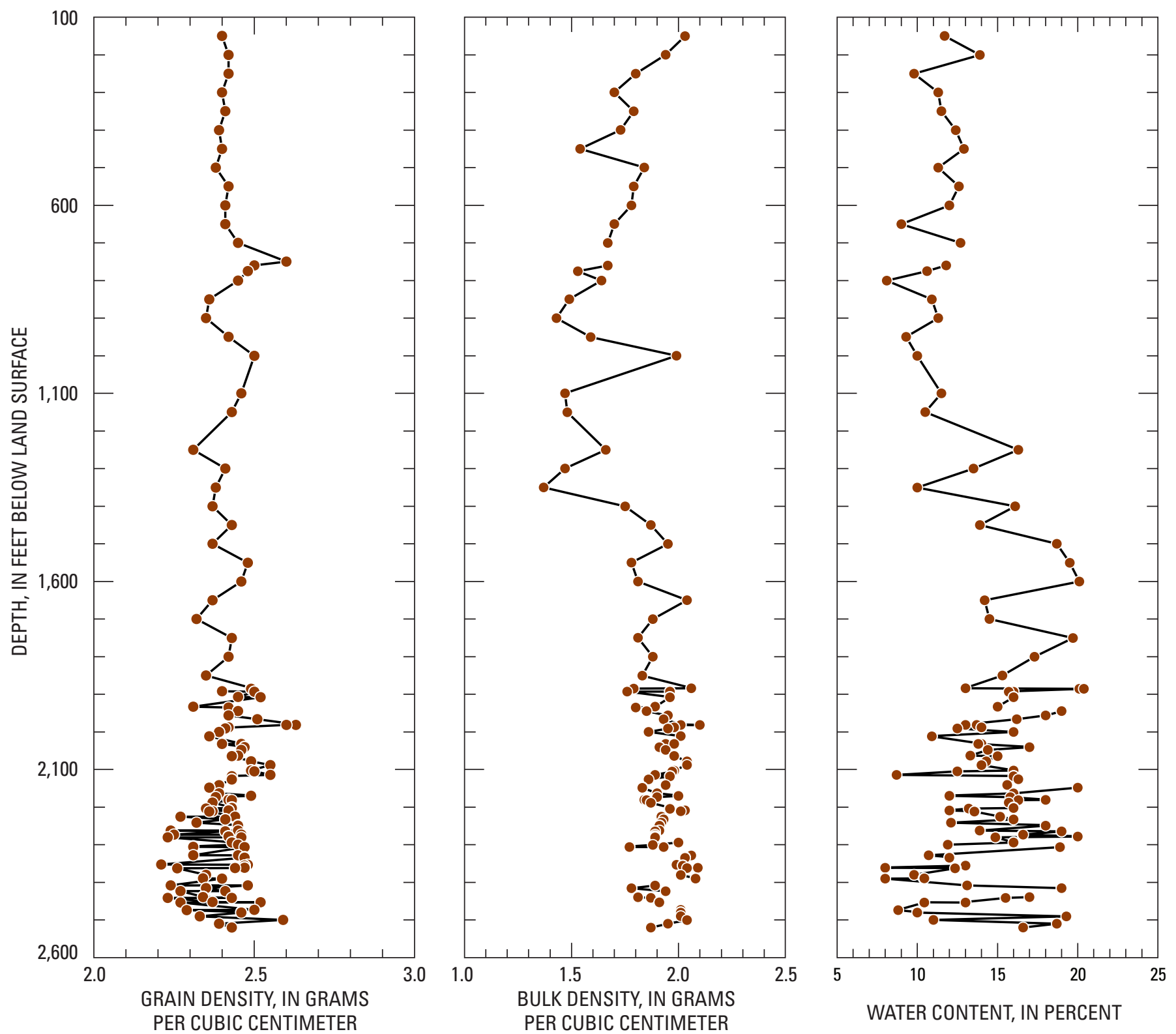

Figure 8. Examples of subsurface rock-property data collected at Nevada Test Site, Nye County, Nevada. Depth profiles of grain density, wet (natural-state) bulk density, and wet water content by weight are from exploratory hole U-4d Ex. \#1. Anomalous values not shown. 


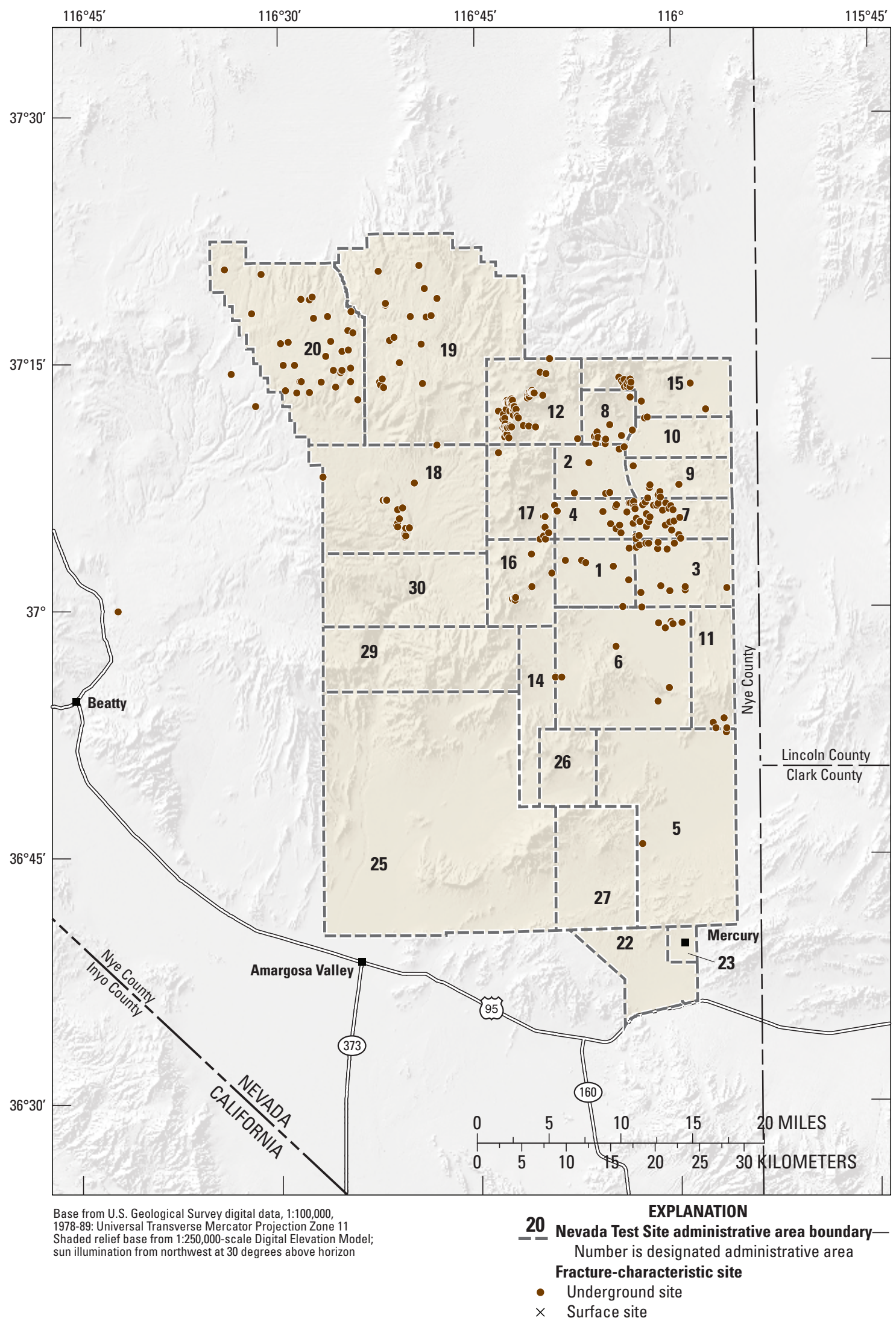

Figure 9. Areal distribution of fracture-characteristic sites in vicinity of Nevada Test Site, Nye County, Nevada. 


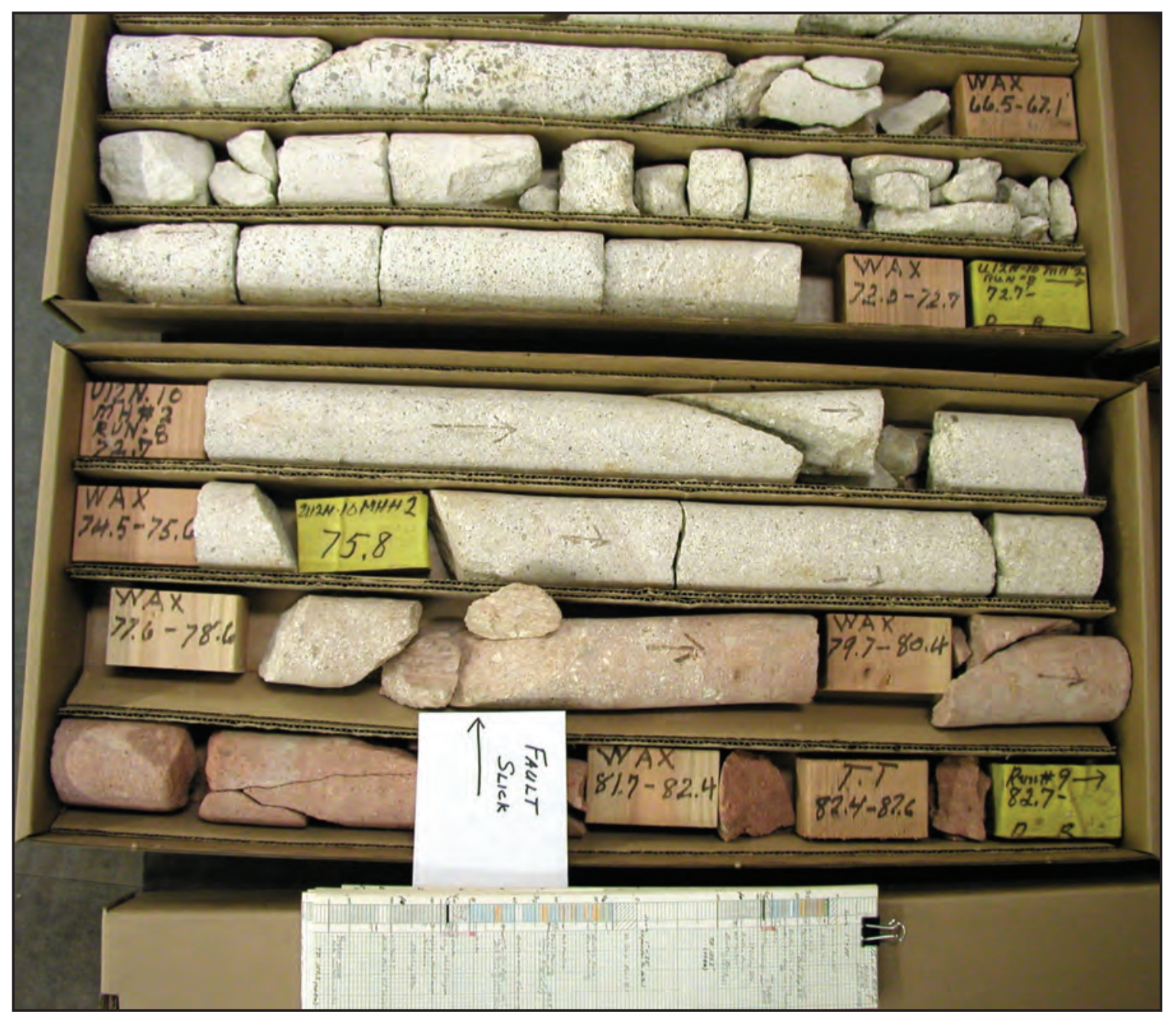

Figure 10. Example of subsurface fracture characteristics in vertical core hole MH-2 in floor of emplacement drift U-12n.10 at 303.77 feet from portal opening, Nye County, Nevada. Core sample shows slickensides and black staining on fracture surfaces at 79 feet. Photograph taken by Jerry Magner, U.S. Geological Survey.

\section{Hydraulic-Property Database}

The USG S compiled interval-specific records of hydraulic-property data for both underground and surface sites located on and around the NTS (fig. 11). The HydraulicProperty database presents water-level response from injection and withdrawal of water during aquifer tests conducted by investigators from DOE/D OD contracting organizations, the $\mathrm{N}$ ational $\mathrm{L}$ aboratories, and USGS. The database is both a digital spreadsheet (appendix E) and table (appendix F).
Field-content headings are described in table E 1. Hydraulic properties have been compiled for sites located in Frenchman and Yucca Flats, and on Buckboard, Pahute, and Rainier M esas (fig. 1). Hydraulic properties are available but have not been compiled for holes located in J ackass Flat (fig. 1).

A quifer testing conducted in water well W W-A and reported in Price and Thordarson (1961) are used to show examples of hydraulic-property data at the NTS. Water-level recovery is shown following bailing tests of $3,000,74$, and 33 gallons, respectively (fig. 12). 


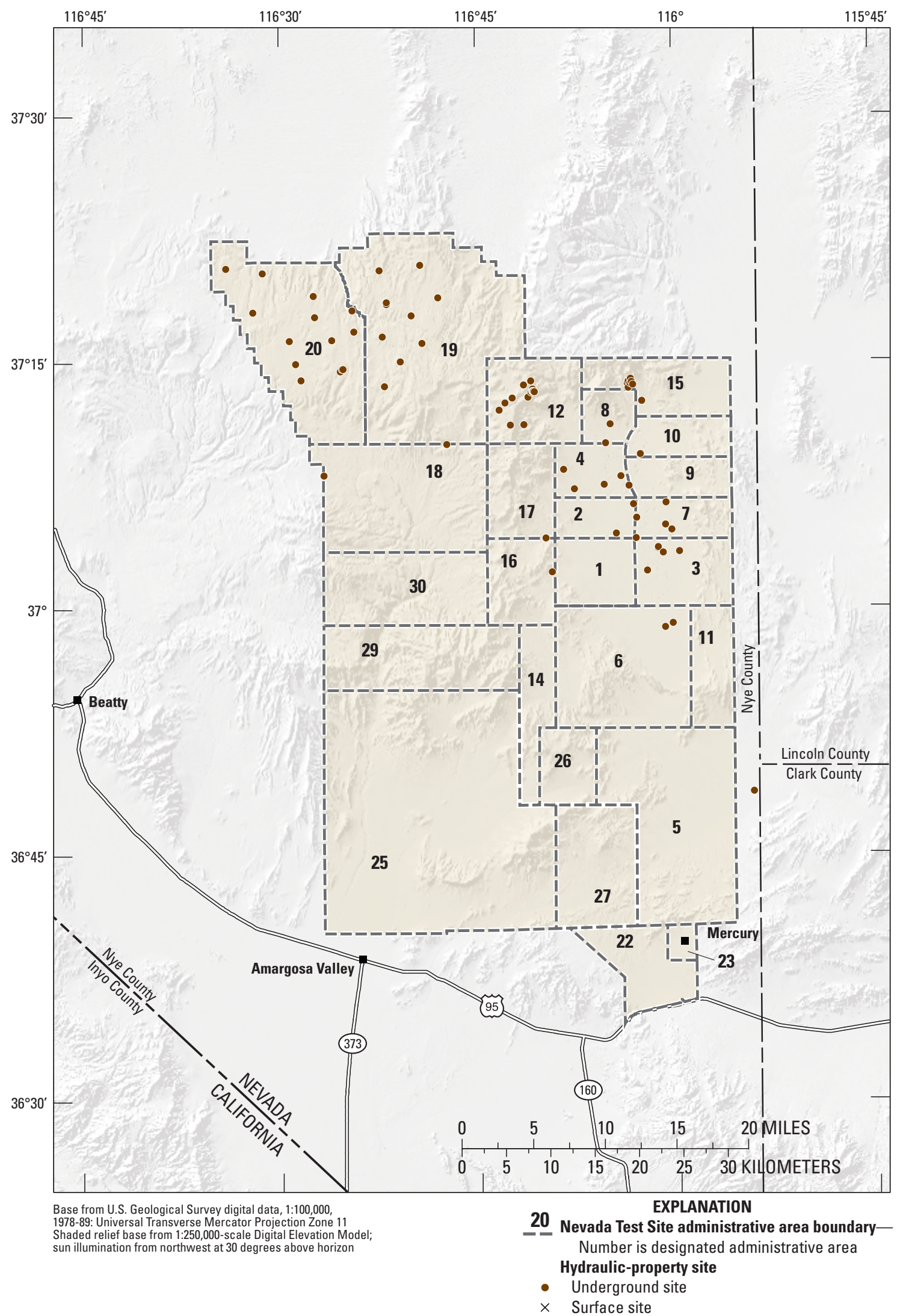

Figure 11. Areal distribution of hydraulic-property sites in vicinity of Nevada Test Site, Nye County, Nevada. 


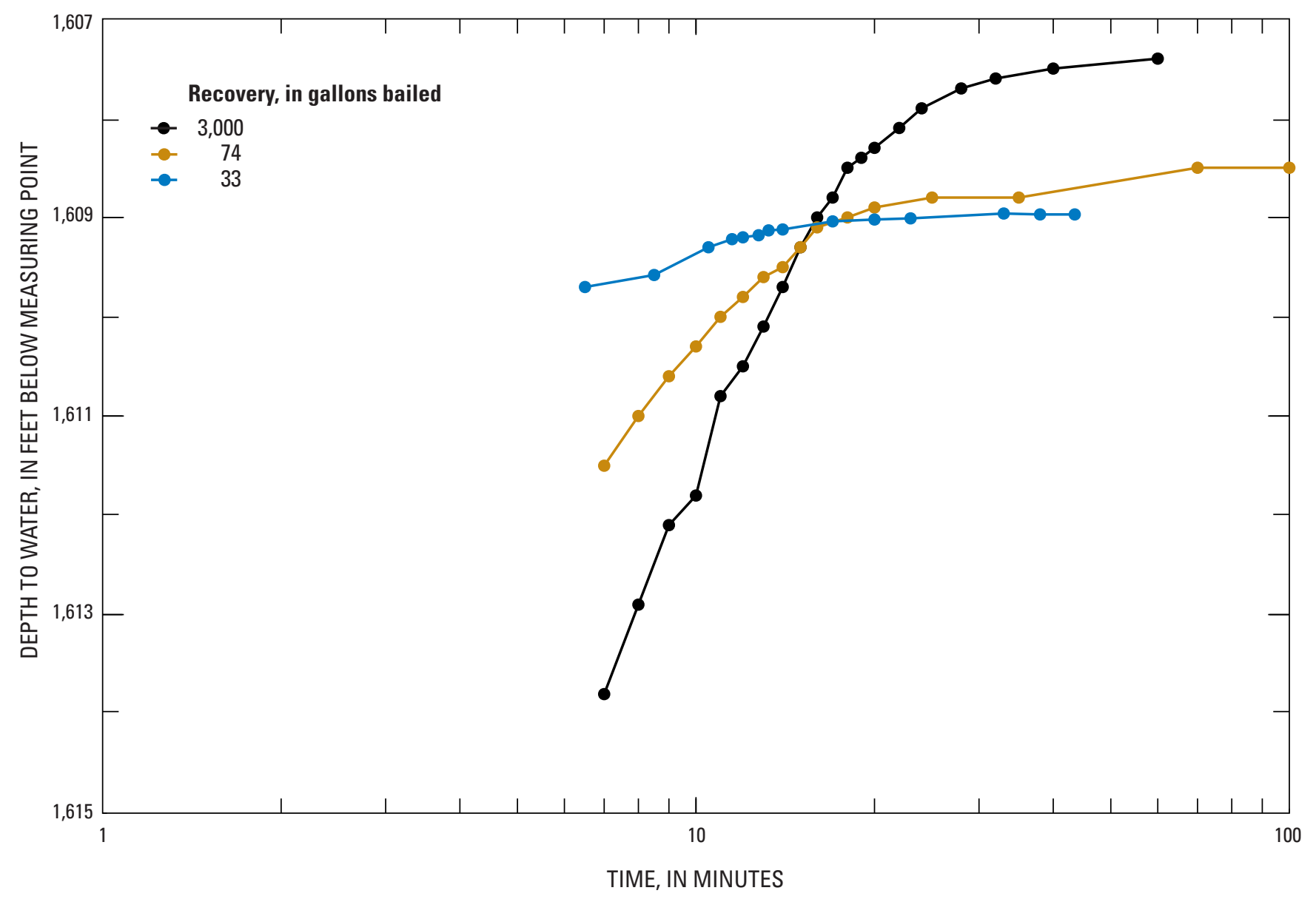

Figure 12. Example of subsurface hydraulic-property data collected at Nevada Test Site, Nye County, Nevada. Recovery shown from three bailing tests conducted in water well WW-A.

\section{Summary}

B etween 1951 and 1992, 828 underground tests were conducted on the N evada Test Site. Prior to and following these nuclear tests, holes (boreholes, shafts, tunnels, and drifts) were drilled and mined for the collection of rock samples. The U.S. Geological Survey has worked in cooperation with U.S. Department of Energy (and its predecessors) and the N ational L aboratories since 1956 and the USGS Core Library and Data Center was established at M ercury, N evada, on the N evada Test Site, through a modification to an existing memorandum of understanding dated A pril 3, 1959. Rock samples collected from these holes are stored in the Core Library and paper copies of records and reports derived from analyses and interpretation of rock samples are stored in the historical files at both the M ercury facility and the USGS office in Henderson, N evada. The understanding of stratigraphy that underlies the NTS and vicinity continues to evolve, through interpretation of rock samples from new holes that are drilled and mined, resulting in a multitude of formal and informal units in common use. Rock samples are irreplaceable because pre-test, in-place conditions cannot be recreated and samples cannot be recollected from the many holes destroyed by testing. The condition of the original paper records is rapidly deteriorating, which makes re-compilation unlikely. Documenting these data in a published report will ensure availability for future investigators.

Rock samples have been catalogued by depth interval for samples stored at the U.S. Geological Survey Core Library. Rock-sample data are compiled from paper records contained in file cabinets and from published reports located at the M ercury facility and at the U.S. Geological Survey Henderson office. R ock samples and thin sections are available for both underground and surface sites located at the N evada Test Site and vicinity. Lithologic descriptions, physical and mechanical properties, fracture characteristics, and hydraulic-property data from aquifer testing are available for sites located in Frenchman and Yucca Flats and on Buckboard, Pahute, and Rainier M esas. Lithologic descriptions also are available for holes located in J ackass Flat. These data have been compiled into five digital spreadsheets. 


\section{Acknowledgments}

The author appreciates the cooperation of Bechtel Nevada; Birdwell Division of Seismograph Service Corporation; Desert Research Institute; Fenix and Scisson of N evada (formerly Fenix and Scisson, Inc.); International Technology Corp.; L os A lamos National Laboratory (formerly L os A lamos Scientific Laboratory); Lawrence Livermore $N$ ational L aboratory (formerly Lawrence Radiation L aboratory); National Security Technologies, LLC; Nevada Division of Water Resources; N evada Testing L aboratories; Pittsburg Testing L aboratory; Raytheon Services N evada; Reynolds Electrical and Engineering $\mathrm{C}$ o.; Sandia $\mathrm{N}$ ational L aboratories; Shaw G roup, Inc.; Stoller-N avarro J oint Venture; Terra Tek, Inc. (a Schlumberger company, sometimes referred to as TerraTek Research); U.S. A ir Force; U.S. A rmy Corps of Engineers Waterways Experiment Station; U.S. D epartment of Energy (formerly Energy Research and Development A dministration; formerly A tomic Energy Commission); U.S. Department of D efense D efense Threat R eduction A gency (formerly D efense Special Weapons A gency; formerly Defense N uclear A gency; formerly D efense A tomic Support A gency); USGS Geologic Division; and U niversity of Illinois Tal bot L aboratory. The author extends special thanks to Gayle A. Pawloski and M avrik Zavarin from Lawrence Livermore National Laboratory; Edward M. K wicklis from L os A lamos National L aboratory; Richard G. Warren from L os A lamos National Laboratory (retired); Sigmond L. Drellack J r., Lance B. Prothro, and M argaret J. Townsend from National Security Technologies, LLC; Charles E. Russell from Desert Research Institute; H arry R. Covington from USGS (retired); Gary L. Dixon from USGS (retired), and J erry E. M agner from USGS (retired).

\section{References Cited}

Blankennagel, R.K., and Weir, J.E., J r., 1973, Geohydrology of the eastern part of Pahute M esa, N evada Test Site, Nye County, N evada: U.S. Geological Survey Professional Paper 712-B, $35 \mathrm{p}$.

Byers, F.M., J r., Carr, W.J ., and Orkild, P.P., 1989, Volcanic centers of Southwestern N evada, Evolution of understanding, 1960-1988: J ournal of Geophysical Research, v. 94, no. B 5, p. 5908-5924.
Byers, F.M ., J r., Carr, W.J ., Orkild, P.P., Quinlivan, W.D., and Sargeant, K.A., 1976, Volcanic suites and related cauldrons of Timber M ountain-Oasis Valley caldera complex, Southern N evada: U.S. Geological Survey Professional Paper 919, $70 \mathrm{p}$.

Cole, J.C., and Cashman, P.H., 1999, Structural relationships of pre-Tertiary rocks in the N evada Test Site region, southern N evada: U.S. Geological Survey Professional Paper 1607, $39 \mathrm{p}$.

Faunt, C.C., D'A gnese, F.A ., and O'B rien, G.M ., 2004, D. Hydrology, in Belcher, W.R., ed., Death Valley regional ground-water flow system, Nevada and California$\mathrm{H}$ ydrogeologic framework and transient ground-water flow model: U.S. Geological Survey Scientific Investigations Report 2004-5205, p. 137-163. On-line at: http://water.usgs. gov/pubs/sir/2004/5205/

Fehner, T.R. and Gosling, F.G., 2000, Origins of the N evada Test Site: U.S. Department of Energy Report DOE/ M A-0518, 95 p.

IT Corporation, 1996a, Underground test area subproject, Phase I, Data analysis task, volume V I-Groundwater flow model data documentation package: $L$ as Vegas, $\mathrm{N}$ ev., Report ITLV /10972-181 prepared for the U.S. Department of Energy, 8 volumes, various pagination.

IT Corporation, 1996b, Underground test area subproject, Phase I, Data analysis task, volume I-Geologic model data documentation package: L as Vegas, N ev., Report ITLV/10972-181 prepared for the U.S. Department of Energy, 8 volumes, variously paginated.

Laczniak, R.J ., Cole, J.C., Sawyer, D.A ., and Trudeau, D .A ., 1996, Summary of hydrogeologic controls on ground-water flow at the N evada Test Site, N ye County, N evada: U.S. Geological Survey Water-Resources Investigations R eport 96-4109, $59 \mathrm{p}$.

Potter, C.J ., Dickerson, R.P., Sweetkind, D.S., Drake II, R.M ., Taylor, E.M., Fridrich, C.J ., San Juan, C.A ., and D ay, W.C., 2002, Geologic map of the Yucca M ountain region, Nye County, Nevada: U.S. Geological Survey Geologic Investigations Series M ap I-2755, 44 p. text, 2 sheets, scale 1:50,000. 
Potter, C.J., Sweetkind, D.S., Dickerson, R.P., and Killgore, M .L., 2001, Hydrostructural map of the Death Valley ground-water basin, Nevada and Cal ifornia: U.S. G eological Survey M iscellaneous Field Studies M ap M F-2372, scale 1:350,000, 2 plates with pamphlet. Available online at: http://greenwood.cr.usgs.gov/pub/mf-maps/mf-2372l

Price, C.E., and Thordarson, William, 1961, Ground water test well A, N evada Test Site, Nye C ounty, N evada-A summary of lithologic data, aquifer tests, and construction: U.S. Geological Survey Trace Elements Investigations Report 800,60 p.

Sawyer, D.A ., Fleck, R.J., L anphere, M .A., Warren, R.G., B roxton, D.E., and Hudson, M.R., 1994, Episodic caldera volcanism in the M iocene southwestern $\mathrm{N}$ evada volcanic field-R evised stratigraphic framework, 40A R/39A R geochronology, and implications from magmatism and extension: Geological Society of A merica Bulletin, v. 106, p. 1304-1318.

Slate, J.L, B erry, M .E., Rowley, P.D., Fridrich, C.J ., M organ, K.S., Workman, J.B., Young, O.D., Dixon, G.L., Williams, V.S., M cK ee, E.H., Ponce, D.A., Hildenbrand, T.G., Swadley, W.C., Lundstrom, S.C., Ekren, E.B., Warren, R.G., Cole, J.C., Fleck, R.J ., L anphere, M .A., Sawyer, D.A ., M inor, S.A., G runwald, D.J ., L aczniak, R.J., M enges, C.M., Yount, J.C., and J ayko, A .S., 2000, Digital geologic map of the N evada Test Site and vicinity, Nye, Lincoln, and Clark Counties, N evada, and Inyo County, California: U.S. Geological Survey Open-File Report 99-554-A, 53 p. text, 2 sheets, scale 1:100,000.

Stewart, J.H., 1980, Geology of Nevada - A discussion to accompany the geologic map of N evada: N evada B ureau of $M$ ines and Geology Special Publication 4, 136 p.
Sweetkind, D.S., B elcher, W.R., Faunt, C.C., and Potter, C.J ., 2004, B. Geology and Hydrogeology, in B elcher, W.R., ed., D eath Valley regional ground-water flow system, $\mathrm{N}$ evada and California- Hydrogeologic framework and transient ground-water flow model: U.S. Geological Survey Scientific Investigations Report 2004-5205, p. 21-98. On-line at: http://water.usgs.gov/pubs/sir/2004/5205/

U.S. Congress, 1989, The containment of underground nuclear explosions: Office of Technology A ssessment, Report OTA ISC-414, $80 \mathrm{p}$.

U.S. Department of Energy, 2000, U nited States N uclear Tests, J uly 1945 through September 1992: N evada Operations Office, Office of External A ffairs, Report NV 0-209, Revision 15, $162 \mathrm{p}$.

U.S. Geological Survey, 2005, U ser's manual for the National Water Information System of the U.S. Geological SurveyGround-Water Site-Inventory System, version 4.4: U.S. Geological Survey O pen-File Report 2005-1251, 274 p.

Warren, R.G, Sawyer, D.A., Byers, F.M ., Jr., and Cole, G.L., 2003, A petrographic, geochemical, and geophysical database, and stratigraphic framework for the southwestern $N$ evada volcanic field: L os A lamos N ational L aboratory Report LA -UR-03-1503, 54 p. Available online at: http:// www.pggdb-swnvf.lanl.gov/

Winograd, I.J., and Thordarson, William, 1975, Hydrogeologic and hydrochemical framework, south-central Great Basin, $\mathrm{N}$ evada-California, with special reference to the N evada Test Site: U.S. G eological Survey Professional Paper 712-C, $126 \mathrm{p}$.

Workman, J.B., M enges, C.M ., Page, W.R., Taylor, E.M., Ekren, E.B., Rowley, P.D., Dixon, G.L., Thompson, R.A., and W right, L.A., 2002, Geologic map of the Death Valley ground-water model area, N evada and California: U.S. Geological Survey M iscellaneous Field Studies M ap M F-2381-A, 26 p., 2 sheets, scale 1:250,000. 
This page left intentionally blank 


\section{Appendixes}

The rock-sample, lithologic-description, rock-property, fracture-characteristic, and hydraulic-property databases distributed with this report are $M$ icrosoft $^{\bullet}$ Excel spreadsheets and listed in the appendixes A-E. Field-content headings are described in tables A 1-E 1 and codes are explained in additional worksheets within each spreadsheet. These databases also are distributed as $\mathrm{M}$ icrosoft ${ }^{\circ} \mathrm{A}$ ccess tables and listed in appendix F. Field-content headings are described in table $\mathrm{F} 1$. . A ppendixes data are available at URL : http://pubs.usgs.gov/ds/2007/297/.

Appendix A. Rock-Sample Database.

Appendix B. Lithologic-Description Database.

Appendix C. Rock-Property Database

Appendix D. Fracture-Characteristic Database.

Appendix E. Hydraulic-Property Database.

Appendix F. NTS USGS Databases. 
This page left intentionally blank 


\section{Appendix A. Rock-Sample Database, Nevada Test Site and Vicinity, Nye County, Nevada}

Rock-sample data were catalogued for rock samples and thin sections (prepared from rock samples) collected from both underground and surface sites on and around the NTS. A ppendix A data are available at URL: http://pubs.usgs.gov/ds/2007/297/.

Table A1. Description of Rock-Sample Database field contents.

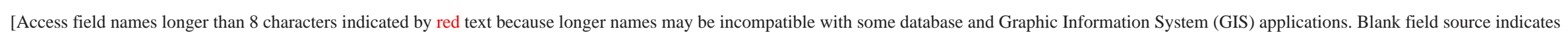

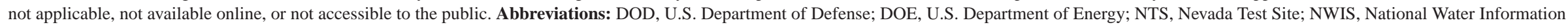
System; USGS, U.S. G eological Survey; ft, foot; -, not applicable]

\begin{tabular}{|c|c|c|c|c|}
\hline Access field name & Excel field name & Field code & Field explanation & Field source \\
\hline SrtOrdUSGS & USGS NTS sort order & - & $\begin{array}{l}\text { Emplacement and exploratory holes typically are displayed together. M any sites also have multiple } \\
\text { completion intervals within the same hole. Therefore, a sort order number is assigned to all USGS } \\
\text { sites associated with DOE and/or DOD projects in N evada. This field is modified as new sites are } \\
\text { added. }\end{array}$ & \\
\hline UnqNoUSGS & $\begin{array}{l}\text { USGS NTS unique } \\
\text { number }\end{array}$ & - & $\begin{array}{l}\text { Spatial }(X-Y) \text { coordinates are unavailable at some locations. Therefore, USGS site identification } \\
\text { numbers cannot be established in the USGS N W IS database Sitefile for these sites. B ecause NWIS } \\
\text { site identification numbers cannot be assigned to all sites, it is necessary to assign a unique site } \\
\text { number to all USGS sites associated with USGS DOE/DOD projects in N evada. A Ithough the } \\
\text { unique numbers were initially assigned in the same order as the USGS NTS sort order, new sites } \\
\text { are assigned the next available sequential number. M ultiple thin section samples at identical UTM } \\
\text { coordinates with identical LAN L PG D Database loc_ids are assigned a common unique number. } \\
\text { M ultiple thin section samples at identical UTM coordinates with different LA N L PGG Database } \\
\text { loc ids are assigned individual unique numbers. Thin section description from Rick Warren } \\
\text { (written commun., Sept. 20, 2008). }\end{array}$ & \\
\hline NTSA rea & NTS area & - & $\begin{array}{l}\text { NTS A dministrative A rea number (see fig. 1). Entries are listed in bold type where sites are located in } \\
\text { areas other than the hole name implies. For example, USG S hole name } \mathbf{U}-\mathbf{2} \mathbf{b w} \text { is actually located } \\
\text { in NTS area } \mathbf{0 9} \text {. }\end{array}$ & \\
\hline HleN meUSGS & USGS hole name & - & $\begin{array}{l}\text { USGS hole name designation. Entries are listed in bold type where sites are located in areas other } \\
\text { than the hole name implies. }\end{array}$ & \\
\hline SmplntNo & $\begin{array}{l}\text { Sample interval } \\
\text { number }\end{array}$ & - & Sequence of sample interval. & \\
\hline SmplntSeq & $\begin{array}{l}\text { Sample interval } \\
\text { sequence number }\end{array}$ & - & Sequence of samples, when multiple samples are reported within a sample interval. & \\
\hline Smpl ntTopft & $\begin{array}{l}\text { Sample interval top } \\
\text { (ft) }\end{array}$ & - & $\begin{array}{l}\text { Depth to top of sample interval; in feet bel ow land surface for boreholes and shafts; in feet from portal } \\
\text { opening for tunnels and drifts. }\end{array}$ & \\
\hline Smpl ntB tmft & $\begin{array}{c}\text { Sample interval } \\
\text { bottom (ft) }\end{array}$ & - & $\begin{array}{l}\text { D epth to bottom of sample interval; in feet bel ow land surface for boreholes and shafts; in feet from } \\
\text { portal opening for tunnels and drifts. }\end{array}$ & \\
\hline
\end{tabular}


Table A1. Description of Rock-Sample Database field contents.-Continued

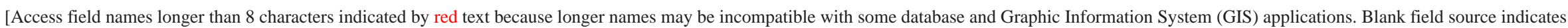

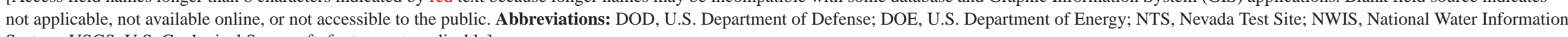
System; USGS, U.S. Geological Survey; ft, foot; -, not applicable]

\begin{tabular}{|c|c|c|c|c|}
\hline Access field name & Excel field name & Field code & Field explanation & Field source \\
\hline NoSmp & Number of samples & - & $\begin{array}{l}\text { N umber of samples for rock-sample interval. Sample types (described below) have a direct bearing } \\
\text { on number of samples reported. A uger, core, and cuttings samples are treated as continuous and the } \\
\text { number of samples is reported as } 1 \text { unless auger or cuttings samples are split into separate boxes for } \\
\text { various preservation and storage types or adjacent core samples are collected from the same depth } \\
\text { interval within a hole. Drill cuttings are normally collected at regular } 10 \text {-foot intervals throughout } \\
\text { the drilling process. H owever, cuttings may be skipped or may be collected at other intervals. } \\
\text { A lso, core often is not fully recovered in the drilling process. These gaps in continuity are noted } \\
\text { by investigators during sample interpretation and analysis. N ormally missing core and cuttings } \\
\text { intervals are minimal and not recorded in this table. }\end{array}$ & \\
\hline SmpTyp & Sample type & - & $\begin{array}{l}\text { Type of sample. M eager field information has been presently accumulated for most thin sections. } \\
\text { For such thin sections, sample types with fairly high probability of correctness are followed by a } \\
\text { question mark enclosed within parentheses [(?)]. Those with moderate probability of correctness } \\
\text { are followed by two question marks enclosed within parentheses [(??)]. Thin section description } \\
\text { from Rick Warren, written commun., July } 25,2009 \text {. }\end{array}$ & \\
\hline SmpTyp & Sample type & A uger & $\begin{array}{l}\text { Collected from a screw-like boring tool and normally collected from unconsolidated material. } \\
\text { A ccuracy is approximate. }\end{array}$ & \\
\hline SmpTyp & Sample type & CF & $\begin{array}{l}\text { Core, not from interval specified. Thin section sample type taken from LAN L Report LA- } \\
\text { UR-03-1503 (2003). }\end{array}$ & $\frac{\text { http://www.pggdb- }}{\text { swnvf.lanl.gov/ }}$ \\
\hline SmpTyp & Sample type & $\mathrm{CL}$ & Lithic from core. Thin section sample type taken from LA NL R eport LA -UR-03-1503 (2003). & $\frac{\text { http://www.pggdb- }}{\text { swnvf.lanl.gov/ }}$ \\
\hline SmpTyp & Sample type & Core & $\begin{array}{l}\text { A cylindrical piece of solid rock taken by a special hollow-type drill bit. Cores are usually about } \\
3 \text { inches in diameter and range from a few inches to several feet in length. Thin section sample type } \\
\text { is "C" in LA NL Report LA-UR-03-1503 (2003). }\end{array}$ & $\frac{\text { http://www.pggdb- }}{\underline{\text { swnvf.lanl.gov/ }}}$ \\
\hline SmpTyp & Sample type & Core, 12 -inch & Core, 12 -inch diameter sample. & \\
\hline SmpTyp & Sample type & Core, 6-inch & Core, 6 -inch diameter sample. & \\
\hline SmpTyp & Sample type & $C P$ & $\begin{array}{l}\text { Single pumice from core. Thin section sample type taken from LA NL Report LA -UR-03-1503 } \\
\text { (2003). }\end{array}$ & $\begin{array}{l}\text { http://www.pggdb- } \\
\text { swnvf.Ianl.gov/ }\end{array}$ \\
\hline SmpTyp & Sample type & Cuttings & $\begin{array}{l}\text { Rock chips or fragments produced by drilling and brought to the surface. Thin section sample type is } \\
\text { "D" in LAN L Report LA -UR-03-1503 (2003). }\end{array}$ & $\frac{\text { http://www.pggdb- }}{\text { swnvf.Ianl.gov/ }}$ \\
\hline SmpTyp & Sample type & $\begin{array}{l}\text { Cuttings, } \\
\text { unwashed }\end{array}$ & Cuttings, unwashed sample. Stored as collected. & \\
\hline SmpTyp & Sample type & $\begin{array}{l}\text { Cuttings, } \\
\text { washed }\end{array}$ & $\begin{array}{l}\text { Cuttings, washed sample. D rill cuttings often contain various forms of debris, drilling mud, and other } \\
\text { contaminants when collected. Samples are placed in a sieve and rinsed with clear running water in } \\
\text { an attempt to remove foreign matter prior to permanent storage. }\end{array}$ & \\
\hline SmpTyp & Sample type & DA & $\begin{array}{l}\text { Cuttings that represent petrographic character of interval. Thin section sample type taken from LANL } \\
\text { Report LA-UR-03-1503 (2003). }\end{array}$ & $\frac{\text { http://www.pggdb- }}{\text { swnvf.lanl.gov/ }}$ \\
\hline
\end{tabular}


Table A1. Description of Rock-Sample Database field contents.-Continued

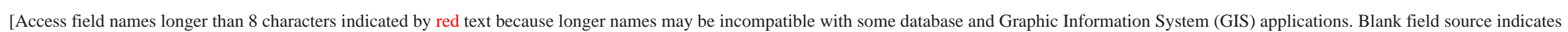

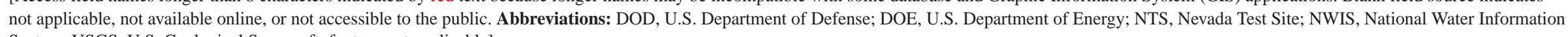
System; USGS, U.S. Geological Survey; ft, foot; - , not applicable]

\begin{tabular}{|c|c|c|c|c|}
\hline Access field name & Excel field name & Field code & Field explanation & Field source \\
\hline SmpTyp & Sample type & DB 1 & $\begin{array}{l}\text { Cuttings enriched in hard components. Thin section sample type taken from LANL Report LA- } \\
\text { UR-03-1503 (2003). }\end{array}$ & $\frac{\text { http://www.pggdb- }}{\text { swnvf.lanl.gov/ }}$ \\
\hline SmpTyp & Sample type & DB2 & $\begin{array}{l}\text { Cuttings from interval different than that drilled. Thin section sample type taken from LANL Report } \\
\text { LA-UR-03-1503 (2003). }\end{array}$ & $\frac{\text { http://www.pggdb- }}{\underline{\text { swnvf.lanl.gov/ }}}$ \\
\hline SmpTyp & Sample type & DB3 & $\begin{array}{l}\text { Cuttings with combined characters of DB1 and DB2. Thin section sample type taken from LANL } \\
\text { Report LA-UR-03-1503 (2003). }\end{array}$ & $\frac{\text { http://www.pggdb- }}{\underline{\text { swnvf.lanl.gov/ }}}$ \\
\hline SmpTyp & Sample type & DB 4 & $\begin{array}{l}\text { Cuttings that are intimate mixture of units. Thin section sample type taken from LANL Report LA- } \\
\text { UR-03-1503 (2003). }\end{array}$ & $\begin{array}{l}\text { http://www.pggdb- } \\
\text { swnvf.lanl.gov/ }\end{array}$ \\
\hline SmpTyp & Sample type & $\mathrm{DL}$ & $\begin{array}{l}\text { Separate of lithics from cuttings. Thin section sample type taken from LA NL R eport LA -UR-03-1503 } \\
\text { (2003). }\end{array}$ & $\frac{\text { http://www.pggdb- }}{\text { swnvf.lanl.gov/ }}$ \\
\hline SmpTyp & Sample type & DM & $\begin{array}{l}\text { Separated mineral from cuttings. Thin section sample type taken from LA NL R eport LA -UR-03-1503 } \\
(2003) .\end{array}$ & $\begin{array}{l}\text { http://www.pggdb- } \\
\text { swnvf.lanl.gov/ }\end{array}$ \\
\hline SmpTyp & Sample type & DP & $\begin{array}{l}\text { Separate of pumice from cuttings. Thin section sample type taken from LANL R eport LA - } \\
\text { UR-03-1503 (2003). }\end{array}$ & $\frac{\text { http://www.pggdb- }}{\text { swnvf.lanl.gov/ }}$ \\
\hline SmpTyp & Sample type & Drill-bit & $\begin{array}{l}\text { Drill-bit sample collected by gouging out rock chips or mud from the cutting parts of a drill bit while } \\
\text { the bit is out of the hole. }\end{array}$ & \\
\hline SmpTyp & Sample type & $F$ & Float. Thin section sample type taken from LA N L R eport LA -UR-03-1503 (2003). & $\frac{\text { http://www.pggdb- }}{\text { swnvf.lanl.gov/ }}$ \\
\hline SmpTyp & Sample type & Grab & $\begin{array}{l}\text { These fist-sized samples come from shafts and tunnels. Samples pried from walls are accurate to } \\
\text { about a foot. Samples taken from debris piles are accurate to about } 10 \mathrm{ft} .\end{array}$ & \\
\hline SmpTyp & Sample type & HL & $\begin{array}{l}\text { Lithic from Hunt sidewall. Thin section sample type taken from LANL Report L A-UR-03-1503 } \\
\text { (2003). }\end{array}$ & $\frac{\text { http://www.pggdb- }}{\text { swnvf.lanl.gov/ }}$ \\
\hline SmpTyp & Sample type & HS & $\begin{array}{l}\text { Hunt sidewall that represents petrographic character of interval. Thin section sample type taken from } \\
\text { LANL Report LA-UR-03-1503 (2003). }\end{array}$ & $\frac{\text { http://www.pggdb- }}{\text { swnvf.lanl.gov/ }}$ \\
\hline SmpTyp & Sample type & HS1 & $\begin{array}{l}\text { Hunt sidewall enriched in hard components. Thin section sample type taken from LA NL R eport LA - } \\
\text { UR-03-1503 (2003). }\end{array}$ & $\frac{\text { http://www.pggdb- }}{\text { swnvf.lanl.gov/ }}$ \\
\hline SmpTyp & Sample type & HW & $\begin{array}{l}\text { Hunt sidewall, wallcake agglomerate of cuttings. Thin section sample type taken from LANL Report } \\
\text { LA-UR-03-1503 (2003). }\end{array}$ & $\frac{\text { http://www.pggdb- }}{\text { swnvf.lanl.gov/ }}$ \\
\hline SmpTyp & Sample type & None & No samples. & \\
\hline SmpTyp & Sample type & 0 & Outcrop. Thin section sample type taken from LAN L Report LA-UR-03-1503 (2003). & $\frac{\text { http://www.pggdb- }}{\text { swnvf.lanl.gov/ }}$ \\
\hline SmpTyp & Sample type & $\mathrm{OL}$ & Lithic from outcrop. Thin section sample type taken from LANL R eport LA-UR-03-1503 (2003). & $\begin{array}{l}\text { http://www.pggdb- } \\
\text { swnvf.lanl.gov/ }\end{array}$ \\
\hline SmpTyp & Sample type & OM & $\begin{array}{l}\text { M ineral separate from outcrop. Thin section sample type taken from LA NL R eport LA-U R-03-1503 } \\
\text { (2003). }\end{array}$ & $\frac{\text { http://www.pggdb- }}{\text { swnvf.lanl.gov/ }}$ \\
\hline
\end{tabular}




\section{Digitally Available Interval-Specific Rock-Sample Data Compiled from Historical Records, Nevada Test Site, Nevada}

Table A1. Description of Rock-Sample Database field contents.-Continued

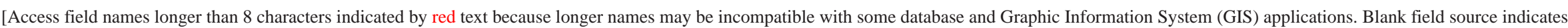

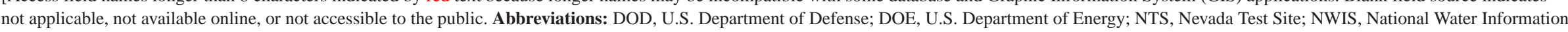
System; USGS, U.S. Geological Survey; ft, foot; -, not applicable]

\begin{tabular}{|c|c|c|c|c|}
\hline Access field name & Excel field name & Field code & Field explanation & Field source \\
\hline SmpTyp & Sample type & OP & $\begin{array}{l}\text { Single pumice or bomb from outcrop. Thin section sample type taken from LA NL Report LA - } \\
\text { UR-03-1503 (2003). }\end{array}$ & $\frac{\text { http://www.pggdb- }}{\text { swnvf.Ianl.gov/ }}$ \\
\hline SmpTyp & Sample type & OPC & $\begin{array}{l}\text { Combined pumices from outcrop. Thin section sample type taken from LAN L Report LA- } \\
\text { UR-03-1503 (2003). }\end{array}$ & $\frac{\text { http://www.pggdb- }}{\text { swnvf.Ianl.gov/ }}$ \\
\hline SmpTyp & Sample type & OPM & $\begin{array}{l}\text { M ineral separate from outcropping pumice. Thin section sample type taken from LANL R eport LA- } \\
\text { UR-03-1503 (2003). }\end{array}$ & $\frac{\text { http://www.pggdb- }}{\underline{\text { swnvf.lanl.gov/ }}}$ \\
\hline SmpTyp & Sample type & P & Trench or pit. Thin section sample type taken from LAN L Report LA-UR-03-1503 (2003). & $\begin{array}{l}\text { http://www.pggdb- } \\
\text { swnvf.Ianl.gov/ }\end{array}$ \\
\hline SmpTyp & Sample type & PP & $\begin{array}{l}\text { Single pumice or bomb from percussion sidewall. Thin section sample type taken from LA NL Report } \\
\text { LA -U R-03-1503 (2003). }\end{array}$ & $\frac{\text { http://www.pggdb- }}{\underline{\text { swnvf.lanl.gov/ }}}$ \\
\hline SmpTyp & Sample type & PS & Percussion sidewall. Thin section sample type taken from LANL Report LA-UR-03-1503 (2003). & $\begin{array}{l}\text { http://www.pggdb- } \\
\text { swnvf.lanl.gov/ }\end{array}$ \\
\hline SmpTyp & Sample type & SC & Sidewall core. Thin section sample type taken from LA N L Report LA -UR-03-1503 (2003). & $\frac{\text { http://www.pggdb- }}{\underline{\text { swnvf.lanl.gov/ }}}$ \\
\hline SmpTyp & Sample type & $\mathrm{SH}$ & Shaft wall. Thin section sample type taken from LANL R eport LA-UR-03-1503 (2003). & $\begin{array}{l}\text { http://www.pggdb- } \\
\text { swnvf.lanl.gov/ }\end{array}$ \\
\hline SmpTyp & Sample type & Sidewall & $\begin{array}{l}\text { These finger-sized samples are collected by shooting or drilling a plug of rock from the wall of an } \\
\text { uncased hole. A ccuracy is about a foot. }\end{array}$ & \\
\hline SmpTyp & Sample type & SL & $\begin{array}{l}\text { Lithic from sidewall core. Thin section sample type taken from LA NL R eport LA -UR-03-1503 } \\
\text { (2003). }\end{array}$ & $\frac{\text { http://www.pggdb- }}{\text { swnvf.Ianl.gov/ }}$ \\
\hline SmpTyp & Sample type & T & Tunnel wall. Thin section sample type taken from LA NL Report LA -UR-03-1503 (2003). & \begin{tabular}{|l} 
http://www.pggdb- \\
swnvf.Ianl.gov/
\end{tabular} \\
\hline SmpTyp & Sample type & V & Vertical hole. Thin section sample type taken from LA NL Report LA -UR-03-1503 (2003). & $\frac{\text { http://www.pggdb- }}{\text { swnvf.Ianl.gov/ }}$ \\
\hline SmpTyp & Sample type & Wax & $\begin{array}{l}\text { Core samples are coated with wax in an attempt to preserve natural-state conditions. Samples are } \\
\text { wrapped with heavy gage aluminum foil then dipped in melted bee's wax. Wax is usually built up in } \\
\text { several layers to about } 1 / 16 \text { inch. }\end{array}$ & \\
\hline SmpOwn & Sample owner & - & $\begin{array}{l}\text { These organizations collected and have proprietary interest in the samples. E ach organization must } \\
\text { be contacted for permission to view and/or analyze their samples. }\end{array}$ & \\
\hline SmpOwn & Sample owner & DOE & DOE. & \\
\hline SmpOwn & Sample owner & DOE/NSTeC & $\begin{array}{l}\text { DOE/National Security Technologies, LLC (NSTec; formerly owned by B echtel, N evada (BN); } \\
\text { formerly owned by Reynolds Electrical and Engineering Co. (REECo)). }\end{array}$ & \\
\hline SmpOwn & Sample owner & $\mathrm{DOE} / \mathrm{ER}$ & DOE/Environmental Restoration Program (ER). & \\
\hline SmpOwn & Sample owner & DTRA & DOD, D efense Threat Reduction A gency (DTRA). & \\
\hline SmpOwn & Sample owner & LANL & Los A lamos N ational Laboratory (LA NL). & \\
\hline
\end{tabular}


Table A1. Description of Rock-Sample Database field contents.-Continued

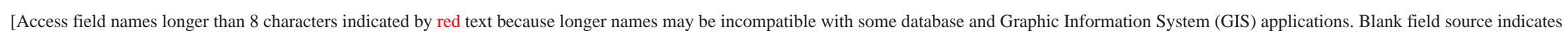

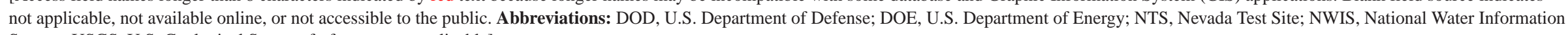
System; USGS, U.S. Geological Survey; ft, foot; -, not applicable]

\begin{tabular}{|c|c|c|c|c|}
\hline Access field name & Excel field name & Field code & Field explanation & Field source \\
\hline SmpOwn & Sample owner & LANL/JVE & LANL/J oint Verification Experiment (JVE). & \\
\hline Smp0wn & Sample owner & LLNL & L aw rence L ivermore National Laboratory (L LNL). & \\
\hline SmpOwn & Sample owner & $\begin{array}{l}\text { LLNL and } \\
\text { DTRA }\end{array}$ & LLNL and DTRA. & \\
\hline SmpOwn & Sample owner & LLNL/SNL & LLNL/Sandia N ational Laboratories (SNL). & \\
\hline Smp0wn & Sample owner & PD & Public Display (PD). & \\
\hline SmpOwn & Sample owner & USGS & USGS. & \\
\hline Comments & Comments & - & Comments pertaining to rock-sample interval. & \\
\hline Comments & Comments & $\begin{array}{l}\text { Bottom hole } \\
\text { core }\end{array}$ & $\begin{array}{l}\text { A rock chip or core sample taken from bottom of borehole. Used to confirm rock unit where hole } \\
\text { bottomed. }\end{array}$ & \\
\hline Comments & Comments & $\begin{array}{l}\text { Rubber } \\
\text { sleeve core }\end{array}$ & $\begin{array}{l}\text { A thick-walled rubber cylinder is used as a "core catcher" to collect unconsolidated material while } \\
\text { using a core bit. The rubber sleeve confines the material keeping it in the order collected. }\end{array}$ & \\
\hline Comments & Comments & Paleo & Refers to drill cuttings collected for pal eontological age dating studies. & \\
\hline AddSmpCol & $\begin{array}{l}\text { A dditional sample } \\
\text { collection }\end{array}$ & - & Samples collected following initial drilling or excavation. & \\
\hline SmpRngTopft & Sample range top (ft) & - & $\begin{array}{l}\text { D epth to top of first sample interval; in feet below land surface for boreholes and shafts; in feet from } \\
\text { portal opening for tunnels and drifts. }\end{array}$ & \\
\hline SmpRngB tmft & $\begin{array}{l}\text { Sample range bottom } \\
(\mathrm{ft})\end{array}$ & - & $\begin{array}{l}\text { D epth to bottom of last sample interval; in feet bel ow land surface for boreholes and shafts; in feet } \\
\text { from portal opening for tunnels and drifts. }\end{array}$ & \\
\hline NoBx & Number of boxes & - & $\begin{array}{l}\text { Total number of standard sample boxes for hole. Standard sample box dimensions are } 13 \text { inches wide } \\
\text { by } 2 \text { feet } 6 \text { inches deep. Height ranges from } 21 / 2 \text { to } 33 / 4 \text { inches. Cardboard core-sample liners are } \\
3 \text { inches ( } 4 \text { per standard storage box), } 31 / 2 \text { inches ( } 3 \text { per standard storage box), and } \\
51 / 4 \text { inches ( } 2 \text { per standard storage box) in height. Therefore, standard storage box heights can } \\
\text { increase to } 51 / 2 \text { inches. M ost cuttings-sample boxes are } 21 / 2 \text { inches wide by } 37 / 8 \text { inches deep } \\
\text { by } 13 / 8 \text { inches high. Standard storage boxes will accommodate } 70 \text { cuttings-sample boxes ( } 5 \text { rows } \\
\text { by } 7 \text { rows, stacked } 2 \text { high). B ecause the majority of cuttings samples are collected every } 10 \text { feet, } \\
\text { this represents } 700 \text { feet of hole. Cuttings-sample boxes used for Environmental Restoration Project } \\
\text { (ER) holes are } 41 / 4 \text { inches wide by } 41 / 4 \text { inches deep by } 2 \text { inches high. Standard storage boxes } \\
\text { will accommodate } 42 \text { ER cuttings-sample boxes ( } 3 \text { rows by } 7 \text { rows, stacked } 2 \text { high). Furthermore, } \\
\text { oversized } 6 \text { - and } 12 \text {-inch cores are stored in wooden crates. }\end{array}$ & \\
\hline SmpBxNme & Sample box name & - & $\begin{array}{l}\text { Name written on sample box located at USGS Core Library in M ercury, N evada. Entries are listed in } \\
\text { bold type where sites are located in areas other than the hole name implies. }\end{array}$ & \\
\hline
\end{tabular}


Table A1. Description of Rock-Sample Database field contents.-Continued

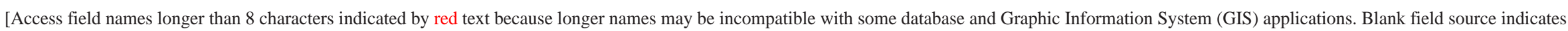

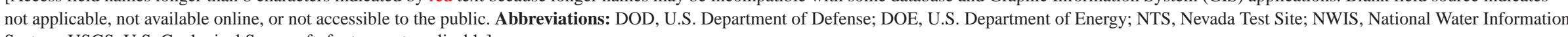
System; USGS, U.S. Geological Survey; ft, foot; - , not applicable]

\begin{tabular}{|c|c|c|c|c|}
\hline Access field name & Excel field name & Field code & Field explanation & Field source \\
\hline SmpRkCISh & $\begin{array}{l}\text { Sample rack-column- } \\
\text { shelf number }\end{array}$ & - & $\begin{array}{l}\text { Samples are stored in two types of storage racks. Rack number } 1 \text { was removed, so racks are numbered } \\
\text { from } 2-99 \text {. Open racks are } 7 \text { bays high and have bay openings that are } 14 \text { inches wide by } 18 \text { inches } \\
\text { high by } 2 \text { feet } 6 \text { inches deep to accommodate standard storage boxes. Samples are ordered in bays } \\
\text { from left to right as A-Z and A A-RR and from bottom to top as } 1-7 \text {. Examples of open rack numbers } \\
\text { are: } 02-A-1 \text { (bottom bay on left side of rack number } 2 \text { ) and } 91-R R-6 \text { (bay } 6 \text { on right side of rack } 91 \text { ). } \\
\text { M ost pallet racks are } 3 \text { bays high and have bay openings that are } 46 \text { inches wide and accommodate } \\
1 \text { pallet containing } 3 \text { standard storage boxes side by side. However some pallet racks are } 4 \text { bays high } \\
\text { and newer pallet racks are } 91 \text { inches wide and accommodate } 2 \text { pallets containing } 6 \text { standard storage } \\
\text { boxes side by side. Height ranges from } 36-54 \text { inches high and depth is over } 5 \text { feet to accommodate } 2 \\
\text { pallets (one behind the other). Samples are ordered on pall ets in bays from left to right as } 1-14 \text { and } \\
\text { from bottom to top as A-D. Examples of pallet rack numbers are: } 89-1-A-R \text { (bottom rear bay in bay } \\
1 \text { on left side of rack } 89 \text { ) and } 83-8-D-F \text { (top front bay in bay } 8 \text { of rack } 83 \text { ). Furthermore, a few odd } \\
\text { sized samples are located on pallets or in wooden crates and stored on the floor at the end of the open } \\
\text { or pallet racks. These locations are given an imaginary bay notation. For example rack } 14 \text { ends at } \\
\text { bay K and rack } 85 \text { ends at bay } 11 \text {. The space between the end of these racks and the building wall is } \\
\text { denoted as an additional bay: } 14-\mathrm{L}-1 \text { or } 85-12-A-F \text {. }\end{array}$ & \\
\hline SmpPalNo & Sample pallet number & - & $\begin{array}{l}\text { Sample pallets are of sufficient width to accommodate } 3 \text { standard storage boxes and number of boxes } \\
\text { varies by height of bay opening. Samples collected at the N evada Test Site (NTS) are numbered by } \\
\text { A dministrative A rea N umber preceded by an "A " followed by the number of pallets for that area. } \\
\text { However, samples collected from tunnels and drifts at A rea } 12 \text { designate the letter of the particular } \\
\text { tunnel following the A dministrative A rea N umber. Samples collected in N evada, but not at the N TS, } \\
\text { are designated as "CNV" (Central N evada) for samples associated with the Faultless project and by } \\
\text { County (CIk, Clark; N ye) for other samples followed by the number of pallets. Samples collected } \\
\text { outside N evada are designated as "A M CH" for samples associated with the A mchitka project in } \\
\text { A laska and by State (Colo, Colorado; M ISS, M ississippi; N M ex, N ew M exico) for other samples } \\
\text { followed by the pallet number. Furthermore, a few samples from California, M ontana, and N ew York } \\
\text { are simply designated as "basket." }\end{array}$ & \\
\hline SmpB xNo & Sample box number & - & $\begin{array}{l}\text { Standard sample boxes are numbered as total per rack bay. The number of storage boxes is normally } \\
\text { shown as the total number of standard storage boxes per sample type per hole, but in cases where } \\
\text { the storage location is not continuous (usually broken by pallet capacity) the total is shown as the } \\
\text { number of boxes on the given pallet or, in a very few cases, storage rack location. }\end{array}$ & \\
\hline LocIDLANL & $\begin{array}{l}\text { LA NL PGG Database } \\
\text { loc_id }\end{array}$ & - & $\begin{array}{l}\text { This unique symbol within the LANL PGG database represents a specific, usually unique location on } \\
\text { the surface, or a specific, usually unique location within a tunnel. The dash character (-) is reserved } \\
\text { for sample IDs and therefore dashes in published locations are converted to a foreslash (/). Thus } \\
\text { 11/102/7A is the loc id for a sample identified by its collector as 11-102-7-A. Description updated } \\
\text { from LAN L Report LA-UR-03-1503 (2003). }\end{array}$ & $\frac{\text { http://www.pggdb- }}{\underline{\text { swnvf.lanl.gov/ }}}$ \\
\hline
\end{tabular}


Table A1. Description of Rock-Sample Database field contents.-Continued

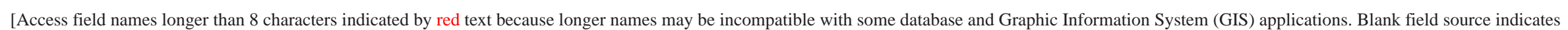

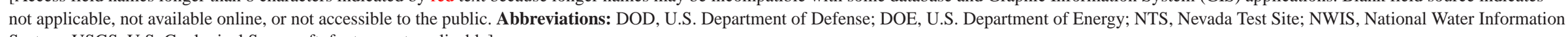
System; USGS, U.S. G eological Survey; ft, foot; - , not applicable]

\begin{tabular}{|c|c|c|c|c|}
\hline Access field name & Excel field name & Field code & Field explanation & Field source \\
\hline SamIDLANL & $\begin{array}{l}\text { LA NL_PGG Database } \\
\text { sam_id }\end{array}$ & - & $\begin{array}{l}\text { This unique symbol within the L AN L PGG database represents up to a few kilograms of contiguous } \\
\text { material from the surface or subsurface. The dash special character (-) designates multiple samples } \\
\text { from a single location, and a left parenthesis '(' designates multiple splits from a single sample. } \\
\text { Samples from vertical drill holes will al ways have sam_id's represented by the location, which is } \\
\text { the drill hole name, followed by a dash (-) and the sample depth in feet, for example, USW G2-770. } \\
\text { Sample depths in meters attach "M " following the metric depth, for example, U SW G2-506.65M. } \\
\text { M ultiple samples from the same location, for example a whole-rock sample and several lithic and } \\
\text { pumice separates, will al ways have sam_id's represented by the location followed by a dash (-) } \\
\text { and a character string, for example RW 18B 3-WR, RW 18B 3-PU 1, and RW 18B 3-PU2. Description } \\
\text { updated from LA NL R eport LA-UR-03-1503 (2003). }\end{array}$ & $\frac{\text { http://www.pggdb- }}{\text { swnvf.lanl.gov/ }}$ \\
\hline SpIIDLANL & $\begin{array}{l}\text { LA NL_PGG Database } \\
\text { spl_id }\end{array}$ & - & $\begin{array}{l}\text { This unique symbol within the LA N L PGG database represents a split of a sample for analysis. } \\
\text { A split represents analysis for one or more element or component that is performed by a single } \\
\text { laboratory. Usually, a few grams are split from the sample and specially prepared for the analytical } \\
\text { procedure, such as a glass-covered thin section for petrographic analysis or pulverized rock for } \\
\text { chemical analysis. Each thin section and each laboratory's chemical analysis represents a separate } \\
\text { split, even if the analyses are performed by different analysts on widely separated dates. Each thin } \\
\text { section represents a split, but each batch of sample pulverized for chemical analysis does not. A } \\
\text { left parenthesis '(' designates each split from a single sample, such as B H 86N/33(B, a polished } \\
\text { thin section for sample B H 86N/33. M ultiple chemical analyses of the same sample by the same } \\
\text { laboratory and multiple analyses of the same thin section are considered to represent replicate } \\
\text { analyses. To represent split analyses, replicate chemical analyses are averaged, weighted by the } \\
\text { inverse square of their analytical uncertainties. Replicate petrographic analyses are ranked; analyses } \\
\text { of the same rank are averaged, weighted by the number of points counted. Individual replicate } \\
\text { analyses are not stored within the database, but analysts and analytical dates and other information } \\
\text { are provided with the analytical data. Description updated from LA L R Report LA-UR-03-1503 } \\
\text { (2003). }\end{array}$ & $\frac{\text { http://www.pggdb- }}{\text { swnvf.lanl.gov/ }}$ \\
\hline SplTypCdL A NL & $\begin{array}{l}\text { LANL PGG Database } \\
\text { split_type_code }\end{array}$ & - & $\begin{array}{l}\text { This symbol identifies the type of sample split analyzed within the LA NL PGG database. A Imost all } \\
\text { petrographic analyses employ a glass-covered or a polished thin section. Allowed symbols below } \\
\text { represent a partial extract from PGG database table split_type_list. Description updated from } \\
\text { LAN L Report LA-UR-03-1503 (2003). }\end{array}$ & $\frac{\text { http://www.pggdb- }}{\text { swnvf.lanl.gov/ }}$ \\
\hline SplTypCdLA NL & $\begin{array}{l}\text { LANL PGG Database } \\
\text { split_type_code }\end{array}$ & 0 & None. & \\
\hline SplTypCdLANL & $\begin{array}{l}\text { LANL PGG Database } \\
\text { split_type_code }\end{array}$ & GCTS & Glass-covered thin section. & \\
\hline SplTypCdLA NL & $\begin{array}{l}\text { LANL PGG Database } \\
\text { split_type_code }\end{array}$ & PTS & Polished section. & \\
\hline
\end{tabular}


Digitally Available Interval-Specific Rock-Sample Data Compiled from Historical Records, Nevada Test Site, Nevada

Table A1. Description of Rock-Sample Database field contents.-Continued

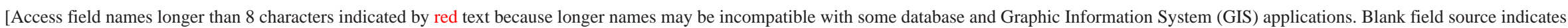

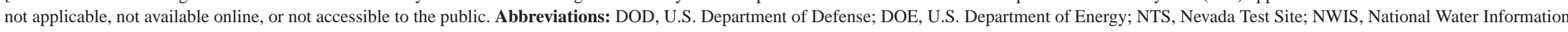
System; USGS, U.S. Geological Survey; ft, foot; -, not applicable]

\begin{tabular}{|c|c|c|c|c|}
\hline Access field name & Excel field name & Field code & Field explanation & Field source \\
\hline SplTypCdLANL & $\begin{array}{l}\text { LA N L PGG Database } \\
\text { split_type_code }\end{array}$ & RLS & R eflected light section. & \\
\hline SplTypCdLANL & $\begin{array}{l}\text { LA NL PGG Database } \\
\text { split_type_code }\end{array}$ & SEM /PTS & Polished section from scanning electron microscope mount. & \\
\hline SplTypCdLANL & $\begin{array}{l}\text { LA NL PGG Database } \\
\text { split_type_code }\end{array}$ & UCTS & Uncovered/unpolished thin section. & \\
\hline SplTypCdLANL & \begin{tabular}{|c}
$\begin{array}{l}\text { LA NL PGG Database } \\
\text { split type_code }\end{array}$ \\
\end{tabular} & UTS & Unknown type of thin section. & \\
\hline ThnSecLbl & Thin section label & - & $\begin{array}{l}\text { L abel permanently inscribed on glass slide. Permanent labels for the great majority of slides are } \\
\text { permanently etched, or for a small fraction are inked onto thick paper that is glued on. Unless it is } \\
\text { the sole identification on a slide, a label inked directly onto a slide is considered temporary. The } \\
\text { comments column provides all inked labels. N ote that a label can be affected by breakage of slides } \\
\text { and a multitude of inscription errors; the label in this column provides the label read from the slide } \\
\text { during inventory. The comments column provides a label corrected for breakage and inscription } \\
\text { errors, usually from notes within the thin section box written by the original users of the slide. } \\
\text { Description from Rick Warren (written commun., A ug. 31, 2008). }\end{array}$ & \\
\hline ThnSecBxID & Thin section box_id & - & $\begin{array}{l}\text { Identification number for box containing the glass slide. A Imost all boxes are standard for the } \\
\text { industry, } 9 \text { to } 9.5 \text { inches long, } 5 \text { to } 5.5 \text { inches wide, and approximately } 1.3 \text { inches high. Each such } \\
\text { box contains } 2 \text { columns of } 50 \text { slots to accommodate } 100 \text { standard glass slides, each } 27 \text { mm by } \\
46 \text { mm by } 1 \mathrm{~mm} \text {. A few smaller cardboard boxes contain } 25 \text { standard glass slides. A single "box" } \\
\text { designates a collection of glass slides or polished thick sections with dimensions different from } \\
\text { those of standard glass slides. Some slides with this "box" had been broken and were repaired by } \\
\text { gluing a reinforcing glass cover slip or second slide and thus too thick to fit within an individual } \\
\text { slot, others were created greatly oversize. Description from Rick Warren (written commun., A ug. } \\
\text { 31, 2008). }\end{array}$ & \\
\hline
\end{tabular}


Table A1. Description of Rock-Sample Database field contents. - Continued

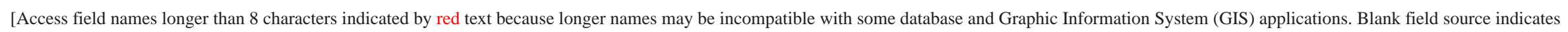

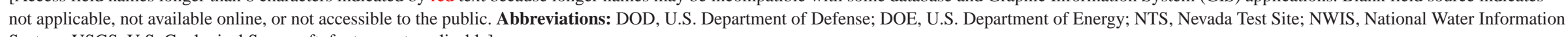
System; USGS, U.S. Geological Survey; ft, foot; - , not applicable]

\begin{tabular}{|c|c|c|c|c|}
\hline Access field name & Excel field name & Field code & Field explanation & Field source \\
\hline ThnSecSIt & Thin section slot & - & 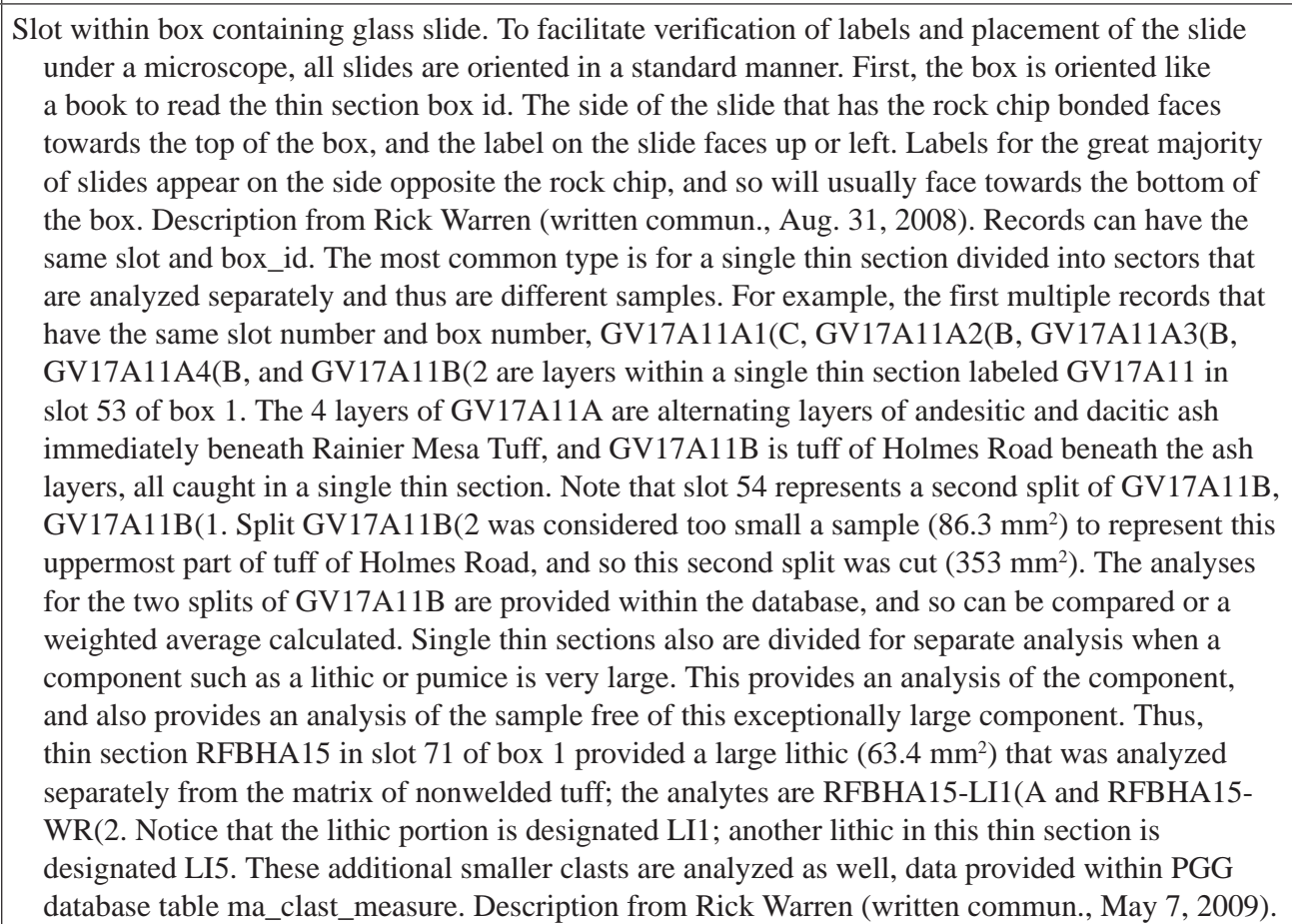 & \\
\hline ThnSecCom & Thin section comments & - & $\begin{array}{l}\text { Comments are taken from sources closely associated with the thin section itself. M ost important } \\
\text { are notes and comments inscribed within the thin section box. These are usually cryptic due to } \\
\text { lack of space, and reproduced as faithfully as legibility allowed. In a very few cases, the original } \\
\text { petrographer included a page of notes within the box describing the thin sections. Comments } \\
\text { describe conspicuous features such as breaks, fractures, and other types of physical degradation of } \\
\text { each slide, and any label additions or modifications made by the original petrographers. Comments } \\
\text { also include information from requisition forms for the thin sections where available. Description } \\
\text { from Rick Warren (written commun., Aug. 31, 2008). }\end{array}$ & \\
\hline SamEIvAvLA NL & $\begin{array}{l}\text { LA NL PGG Database } \\
\text { sam_elev_av }\end{array}$ & - & $\begin{array}{l}\text { This value provides the sample el evation above mean sea level, or the average from uppermost and } \\
\text { low ermost bounds, if available. All values are in feet, but are instead in meters within the LA NL } \\
\text { PGG database. }\end{array}$ & $\frac{\text { http://www.pggdb- }}{\text { swnvf.lanl.gov/ }}$ \\
\hline
\end{tabular}


Table A1. Description of Rock-Sample Database field contents.-Continued

[A ccess field names longer than 8 characters indicated by red text because longer names may be incompatible with some database and Graphic Information System (GIS) applications. Blank field source indicates not applicable, not available online, or not accessible to the public. Abbreviations: DOD, U.S. Department of D efense; DOE, U.S. Department of Energy; NTS, Nevada Test Site; NW IS, National Water Information System; USGS, U.S. Geological Survey; ft, foot; -, not applicable]

\begin{tabular}{|c|c|c|c|c|}
\hline Access field name & Excel field name & Field code & Field explanation & Field source \\
\hline SamEIvU ncL ANL & $\begin{array}{l}\text { LA NL_PGG Database } \\
\text { sam_elev_unc }\end{array}$ & - & $\begin{array}{l}\text { This value provides the uncertainty for sample elevation, or one-half the difference between } \\
\text { uppermost and lowermost bounds, if available. All values are in feet, but are instead in meters } \\
\text { within the LA NL PG database. Description updated from LANL Report LA-UR-03-1503 (2003). }\end{array}$ & $\frac{\text { http://www.pggdb- }}{\text { swnvf.lanl.gov/ }}$ \\
\hline EntDtLANL & $\begin{array}{l}\text { LANL PGG Database } \\
\text { entry_date }\end{array}$ & - & $\begin{array}{l}\text { This date indicates the day in which the data entry was created for loading into the LANL database. } \\
\text { This entry within the LA NL PGG database requires a four-digit year specifier; e.g. 05-JUN-1998. } \\
\text { Description updated from LANL Report LA-UR-03-1503 (2003). }\end{array}$ & $\begin{array}{l}\text { http://www.pggdb- } \\
\text { swnvf.lanl.gov/ }\end{array}$ \\
\hline M apUntSym & M ap unit symbol & - & $\begin{array}{l}\text { A list of map unit symbols commonly used at the NTS and vicinity are provided. For example: [QTa } \\
\text { - middle Pleistocene to late Tertiary alluvial deposits; Tac - M iocene Calico Hills Formation; Tbgr } \\
\text { - Tertiary crystal-rich Grouse Canyon Tuff; T T cpk - Tertiary R Ryolite of Kearsarge; TnA BCD - } \\
\text { Tertiary Tunnel Formation, } 4 \text { M ember, beds } 4 A, 4 B, 4 C \text {, and } 4 D ; O \text { aa - Ordovician A ntelope Valley } \\
\text { Limestone, Aysees Peak M ember; and Dg - upper and middle Devonian G uilmette Formation]. } \\
\text { A complete list of codes is included in the map_unt worksheet in the nts_rck_smp spreadsheet } \\
\text { (appendix A). }\end{array}$ & \\
\hline RecLoc & Record location & - & Physical location of rock-sample record. & \\
\hline HleTyp & Hole type & - & Type of vertical or horizontal drilling or excavation. & \\
\hline HleTyp & Hole type & Borehole & Vertical surface location; includes wells and vertical test holes. & \\
\hline HleTyp & Hole type & Crater & Vertical surface location. & \\
\hline HleTyp & Hole type & Drift & Horizontal underground location; includes tunnels and horizontal test holes. & \\
\hline HleTyp & Hole type & $\begin{array}{l}\text { Multiple } \\
\text { Wells }\end{array}$ & M ultiple wells. & \\
\hline HleTyp & Hole type & Outcrop & Surface location. & \\
\hline HleTyp & Hole type & Shaft & Vertical surface location. & \\
\hline HleTyp & Hole type & Spring & Spring. & \\
\hline HleTyp & Hole type & Streambed & Streambed. & \\
\hline HleTyp & Hole type & Surface & Surface location. & \\
\hline HleTyp & Hole type & Trench & Horizontal surface location. & \\
\hline HleTyp & Hole type & Unknown & Hole type not known. & \\
\hline TnlDftConSta & $\begin{array}{c}\text { Tunnel or drift } \\
\text { construction station }\end{array}$ & - & $\begin{array}{l}\text { Construction station at collar location (portal opening), for tunnels and drifts (i.e. - } 9+17 \text { is } 917 \mathrm{ft} \text {; } \\
10+72,195 \text { ' is a } 195 \mathrm{ft} \text { hole at the } 1,072 \mathrm{ft} \text { station; etc.). }\end{array}$ & \\
\hline ConStaR mk & $\begin{array}{l}\text { Construction station } \\
\text { remarks }\end{array}$ & - & $\begin{array}{l}\text { Remarks concerning the portal opening (collar location), for tunnels and drifts (i.e. - In U-12e.14 } \\
\text { main drift; A Icove; Face; Invert; Lft Rib; Rt Rib; etc.). }\end{array}$ & \\
\hline NV SPE 27 & $\begin{array}{l}\text { Nevada SPCS Easting } \\
\text { NAD } 27\end{array}$ & - & $\begin{array}{l}\text { N evada State plane coordinates (SPCS), Easting, central zone, in feet; North A merican D atum of } \\
1927 \text { (NAD 27). }\end{array}$ & \\
\hline
\end{tabular}


Table A1. Description of Rock-Sample Database field contents. - Continued

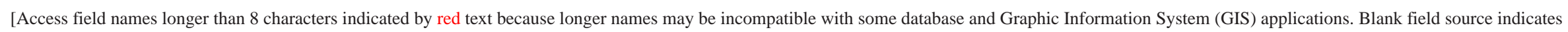

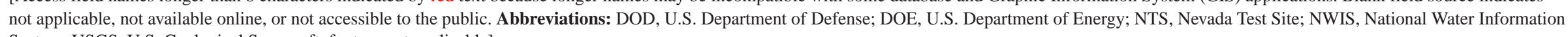
System; USGS, U.S. Geological Survey; ft, foot; - , not applicable]

\begin{tabular}{|c|c|c|c|c|}
\hline Access field name & Excel field name & Field code & Field explanation & Field source \\
\hline NVSPN 27 & $\begin{array}{l}\text { N evada SPCS } \\
\text { N orthing NA D } 27\end{array}$ & - & $\begin{array}{l}\text { N evada State plane coordinates (SPCS), N orthing, central zone, in feet; N orth A merican Datum of } \\
1927 \text { (NA D 27). }\end{array}$ & \\
\hline NVSPErr & SPCS error & - & SPCS error, in feet. Blank if unknown. & \\
\hline AltPorOpn29ft & $\begin{array}{l}\text { A ltitude at portal } \\
\text { opening NGVD } 29 \\
\text { (ft) }\end{array}$ & - & $\begin{array}{l}\text { A ltitude at the collar location of the portal opening, for tunnels and drifts; in feet above mean sea } \\
\text { level; N ational G eodetic Vertical Datum of } 1929 \text { (N GV D 29). }\end{array}$ & \\
\hline BngPorOpnDeg & $\begin{array}{l}\text { B earing from portal } \\
\text { opening (degrees) }\end{array}$ & - & $\begin{array}{l}\text { B earing from the portal opening, for tunnels and drifts; in degrees, minutes, and seconds or decimal } \\
\text { degrees (i.e. - S0720958W is South, } 72 \text { degrees, } 9 \text { minutes, } 58 \text { seconds West; N 0325529E is N orth, } \\
32 \text { degrees, } 55 \text { minutes, } 29 \text { seconds East; N 052.75W is N orth } 52 \text { and three-quarter degrees West; } \\
\text { etc.) }\end{array}$ & \\
\hline IncPorO pnD eg & $\begin{array}{l}\text { Inclination from portal } \\
\text { opening (degrees) }\end{array}$ & - & $\begin{array}{l}\text { Inclination from the portal opening, for tunnels and drifts; in degrees, minutes, and seconds or } \\
\text { decimal degrees (i.e. - } 0045825 \text { is a hole } 4 \text { degrees, } 58 \text { minutes, } 25 \text { seconds above horizontal; } \\
2700000 \text { is a vertical hole bel ow horizontal; } 0900000 \text { is a vertical hole above horizontal; } 0000000 \\
\text { and } 1800000 \text { are horizontal holes; } 0150000 \text { and } 1650000 \text { are holes } 15 \text { degrees up (above } \\
\text { horizontal); } 3150000 \text { and } 2250000 \text { are holes } 45 \text { degrees down (below horizontal); } 356.5 \text { is a hole } \\
3 \text { and one-half degrees below horizontal; } 170.25 \text { is } 9 \text { and three-quarter degrees above horizontal; } \\
\text { etc.). Inclinations are linked to bearings, so values near horizontal for holes bearing north or east } \\
\text { would be added to zero for holes inclined above horizontal and subtracted from } 360 \text { for holes below } \\
\text { horizontal; conversely, values near horizontal for holes bearing south or west would be subtracted } \\
\text { from } 180 \text { for holes inclined above horizontal and added to } 180 \text { for holes bel ow horizontal. }\end{array}$ & \\
\hline AltL ndSur29ft & $\begin{array}{l}\text { A ltitude of land } \\
\text { surface N GV D29 } \\
\text { (ft) }\end{array}$ & - & $\begin{array}{l}\text { A ltitude of land surface within a reasonable proximity of the site; in feet above mean sea level; } \\
\text { National Geodetic Vertical Datum of } 1929 \text { (N GV D 29). This is an average of the surrounding } \\
\text { ground-surface el evation. If the original surface has been altered, estimate the altitude based on } \\
\text { nearby unaltered terrain. }\end{array}$ & \\
\hline AltM th & A ltitude method & - & M ethod used to determine altitude of Iand surface. & \\
\hline AltM th & A ltitude method & A & Altimeter. & \\
\hline AltM th & Altitude method & D & Differentially corrected Global Positioning System (DGPS). & \\
\hline AltM th & Altitude method & G & Global Positioning System (GPS). & \\
\hline AltM th & Altitude method & I & Interferometric Synthetic A perture R adar (IfSA R), airplane. & \\
\hline AltM th & Altitude method & J & Light D etection A nd Ranging (LiDA R), airplane. & \\
\hline AltM th & Altitude method & $\mathrm{L}$ & Level or other surveying method. & \\
\hline AltM th & Altitude method & M & $\begin{array}{l}\text { Interpolated from topographic map [report accuracy as } \pm \text { one-half the contour interval (or } \\
\text { supplementary contour interval) specified on the quadrangle]. }\end{array}$ & \\
\hline AltM th & Altitude method & $\mathrm{N}$ & Interpolated from digital el evation model (DEM ). & \\
\hline AltM th & Altitude method & $\mathrm{R}$ & Reported. & \\
\hline
\end{tabular}


Digitally Available Interval-Specific Rock-Sample Data Compiled from Historical Records, Nevada Test Site, Nevada

Table A1. Description of Rock-Sample Database field contents.-Continued

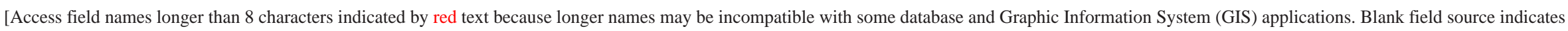

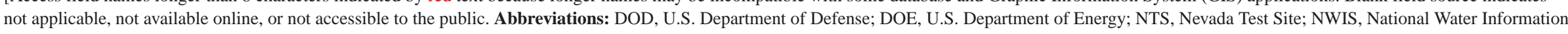
System; USGS, U.S. Geological Survey; ft, foot; -, not applicable]

\begin{tabular}{|c|c|c|c|c|}
\hline Access field name & Excel field name & Field code & Field explanation & Field source \\
\hline AltM th & Altitude method & $\mathrm{U}$ & Unknown. & \\
\hline AltACC & A ltitude accuracy & - & Altitude accuracy; in feet (decimal values for accuracies less than $1 \mathrm{ft}$ ). & \\
\hline AltACC & Altitude accuracy & U & Unknown. & \\
\hline SitCmpDt & Site completion date & - & Date hole construction completed. & \\
\hline HleDthft & Hole depth (ft) & - & $\begin{array}{l}\text { Hole depth; in feet below land surface for boreholes and shafts; in feet from portal opening for tunnels } \\
\text { and drifts. }\end{array}$ & \\
\hline RedBkHleNo & Redbook hole number & - & $\begin{array}{l}\text { Redbook hole numbers are currently assigned to new holes completed at the NTS by National } \\
\text { Security Technologies, LLC (N STec). Entries are listed in bold type where sites are located in areas } \\
\text { other than the hole name implies. }\end{array}$ & \\
\hline RedBkHleNo & Redbook hole number & - & $\begin{array}{l}\text { Redbook hole numbers listed in the Raytheon Services N evada (RSN) N evada Test Site D rilling } \\
\text { and M ining Summary (last updated 12-31-90) and previously in the Fenix and Scisson of N evada } \\
\text { NTS D rilling and M ining Summary (last updated 6-30-89; formerly Fenix and Scisson, Inc.) were } \\
\text { assigned according to the type of hole drilled or mined, site location (NTS area), and sequence code } \\
\text { for the consecutive order in which the hole was drilled, mined, or recompleted. E mplacement holes } \\
\text { for nuclear weapons tests begin with the letter U, followed by a dash (-), NTS area number (fig. 1), } \\
\text { and sequence code (letters a-Z, aa-az, ba-bz, ..., za-zz). Exploratory holes follow the same naming } \\
\text { convention as emplacement holes, but begin with the letters UE. Holes that begin with the letter U but } \\
\text { were drilled or mined specifically to provide data that could not be collected from an emplacement } \\
\text { hole follow the emplacement hole naming convention, but are assigned incremental letters or } \\
\text { numbers, or both following the sequence code. The suffix letters indicate: [\#, satellite hole; CH, cable } \\
\text { hole; Ex. or Expl., exploratory hole; HTH, hydrologic test hole; Inst., instrument hole; ITS, integrated } \\
\text { test system; PPS, pre-postshot hole; PS, post-shot hole; R N M, radionuclide migration hole; RW M S, } \\
\text { radioactive waste management site; and S, substitute hole]. There are numerous exceptions to the } \\
\text { standard naming convention. The prefix letters indicate: [HTH, hydrologic test hole; J, Jackass Flat; } \\
\text { and R N M radionuclide migration]. N umbers and letters following the dash in the exceptions represent } \\
\text { sequence of site drilling or mining, not NTS location. Hole type al so is commonly listed after the hole } \\
\text { designation. For example: [A ccess Shaft; Cable Hole; Expl. Hole; Instrument; LOS (L ine Of Sight) } \\
\text { Drift; Sidetrack; R eentry M ining; Tunnel; Vent Hole; and Zero Station]. }\end{array}$ & \\
\hline RedB kHleNo & Redbook hole number & - & $\begin{array}{l}\text { USGS DOE project-related holes in Central N evada follow a similar naming convention. However, } \\
\text { emplacement holes begin with the letters UC and exploratory holes begin with the letters UCE. }\end{array}$ & \\
\hline RedB kHleNo & Redbook hole number & - & $\begin{array}{l}\text { USGS Yucca M ountain Project (Y M P) holes at the NTS follow the exploratory hole naming convention. } \\
\text { Offsite Y M P holes begin with the letters USW to indicate underground southern N evada waste. } \\
\text { The suffix letters indicate: [G, geologic hole; GA, geologic angle hole; GU, geologic unsaturated } \\
\text { zone hole; H, hydrologic hole; M X, missile-experimental hole (drilled for U.S. A ir Force [USA F ] } \\
\text { MX M issile-Siting Investigation); N, neutron hole; p, Paleozoic or pre-Tertiary hole; RF, repository } \\
\text { facility hole; UZ, unsaturated zone hole; V, volcanic hole; VSE, vertical shelter exploratory hole } \\
\text { (drilled for USA F M X M issile-Siting Investigation); and WT, water table hole]. }\end{array}$ & \\
\hline
\end{tabular}


Table A1. Description of Rock-Sample Database field contents.-Continued

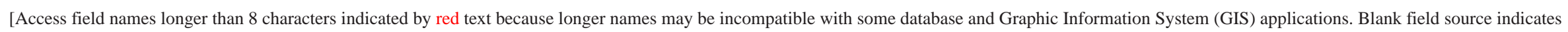

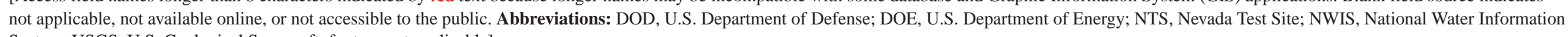
System; USGS, U.S. Geological Survey; ft, foot; - , not applicable]

\begin{tabular}{|c|c|c|c|c|}
\hline Access field name & Excel field name & Field code & Field explanation & Field source \\
\hline RedB kHleNo & Redbook hole number & - & $\begin{array}{l}\text { Environmental Restoration Program (ERP) holes at the NTS begin with the letters ER, followed by a } \\
\text { dash, NTS area number (fig. 1), a dash, and an incremental sequence number. The NTS area number } \\
\text { is replaced by suffix letters for ERP holes located offsite. The suffix letters indicate: [EC, area at the } \\
\text { USAF N ellis A ir Force B ase R ange (NAFBR) where the holes were drilled; and OV, O asis Valley]. }\end{array}$ & \\
\hline RedB kHleNo & Redbook hole number & - & 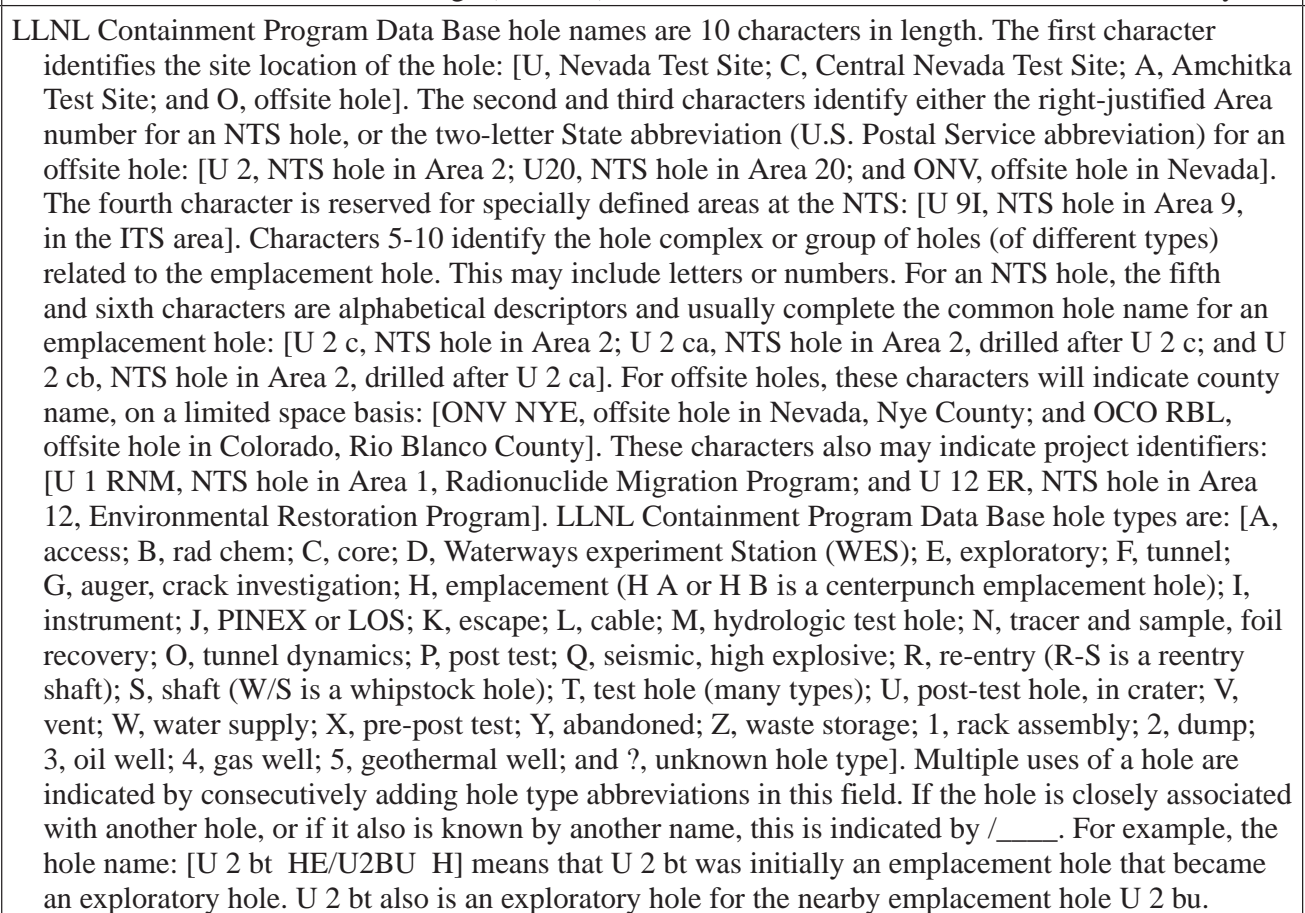 & \\
\hline FmrOthHleN me & $\begin{array}{l}\text { Former or other hole } \\
\text { name }\end{array}$ & - & Former or other names utilized for holes. & \\
\hline A gyCdU SGSN WIS & NWIS agency code & USGS & $\begin{array}{l}\text { USGS N W IS code to indicate the reporting agency. All sites currently populated in the rock-sample } \\
\text { database are assigned as USGS. }\end{array}$ & \\
\hline SitIDNoUSGSNWIS & $\begin{array}{l}\text { NWIS site } \\
\text { identification } \\
\text { number }\end{array}$ & - & USGS NWIS site identification number. & \\
\hline
\end{tabular}




\section{Digitally Available Interval-Specific Rock-Sample Data Compiled from Historical Records, Nevada Test Site, Nevada}

Table A1. Description of Rock-Sample Database field contents.-Continued

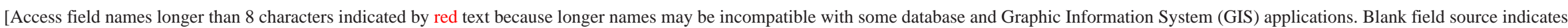

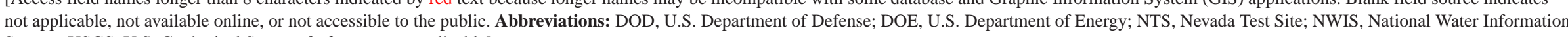
System; USGS, U.S. Geological Survey; ft, foot; -, not applicable]

\begin{tabular}{|c|c|c|c|c|}
\hline Access field name & Excel field name & Field code & Field explanation & Field source \\
\hline Sitl D N oU SG SN WIS & $\begin{array}{l}\text { NWIS site } \\
\text { identification } \\
\text { number }\end{array}$ & - & $\begin{array}{l}\text { D ownstream order numbers are assigned for surface-water, on-stream, sites. The first two digits of the } \\
\text { station number indicate the part or major drainage system formerly used for USGS Water-Supply } \\
\text { Papers entitled "Surface Water Supply of the U nited States" and the remaining digits indicate } \\
\text { the downstream order within the part. This site number is left-justified. A lthough downstream } \\
\text { identification numbers have been converted to a variable length format, with up to } 14 \text { digits } \\
\text { available, } 8 \text { digits are normally assigned. }\end{array}$ & \\
\hline SitI DN oU SGSN WIS & $\begin{array}{l}\text { NWIS site } \\
\text { identification } \\
\text { number }\end{array}$ & - & $\begin{array}{l}\text { Numbering system for sites on open water bodies, off-channel sites, wells, springs, etc., is based on } \\
\text { the grid system of latitude and longitude. Although this number is initially determined from the best } \\
\text { known latitude/longitude location, plus a 2-digit sequence number for the number of sites located } \\
\text { at those coordinates, it retains no locational relevance once the site is created in the database. The } \\
\text { overall designation consists of } 15 \text { digits. The values of latitude and longitude are updated as better } \\
\text { coordinates become available, and should always be used for locating sites or plotting locations. }\end{array}$ & \\
\hline Lat27 & Latitude NAD 27 & - & $\begin{array}{l}\text { L atitude; in degrees, minutes, and seconds [two digits are available for decimal seconds]; North } \\
\text { A merican Datum of } 1927 \text { (NA D 27). }\end{array}$ & \\
\hline Lng27 & Longitude NA D27 & - & $\begin{array}{l}\text { L ongitude; in degrees, minutes, and seconds [two digits are available for decimal seconds]; North } \\
\text { A merican Datum of } 1927 \text { (NA D27). }\end{array}$ & \\
\hline LocM th & Location method & - & M ethod used to determine latitude and longitude coordinates. & \\
\hline LocM th & Location method & A & $\begin{array}{l}\text { A pproximate: location estimated long after sampling. Thin section location method taken from LA NL } \\
\text { R eport LA -UR-03-1503 (2003). }\end{array}$ & $\frac{\text { http://www.pggdb- }}{\underline{\text { swnvf.Ianl.gov/ }}}$ \\
\hline LocM th & Location method & B & $\begin{array}{l}\text { Digitized from master map, generally stable base. Thin section location method is "S" in LA NL } \\
\text { Report LA -U R-03-1503 (2003); description taken from report. }\end{array}$ & $\frac{\text { http://www.pggdb- }}{\text { swnvf.lanl.gov/ }}$ \\
\hline LocM th & Location method & C & Calculated from land net. & \\
\hline LocM th & Location method & $\mathrm{D}$ & Differentially corrected G lobal Positioning System (D GPS). & \\
\hline LocM th & Location method & $\mathrm{F}$ & $\begin{array}{l}\text { Digitized from field map. Thin section location method is "D" in LA NL Report LA -UR-03-1503 } \\
\text { (2003); description taken from report. }\end{array}$ & $\begin{array}{l}\text { http://www.pggdb- } \\
\text { swnvf.Ianl.gov/ }\end{array}$ \\
\hline LocM th & Location method & G & $\begin{array}{l}\text { Global positioning system (GPS), uncorrected [Standard Positioning Service (SPS) and Precise } \\
\text { Positioning Service (PPS)]. }\end{array}$ & \\
\hline LocM th & Location method & H & $\begin{array}{l}\text { Hand-calculated from location plotted during sampling. Thin section location method taken from } \\
\text { LA NL R eport LA -UR-03-1503 (2003). }\end{array}$ & $\frac{\text { http://www.pggdb- }}{\text { swnvf.lanl.gov/ }}$ \\
\hline LocM th & Location method & $\mathrm{L}$ & L ong-range navigation (L oran) system. & \\
\hline LocM th & Location method & M & Interpolated from map. & \\
\hline LocM th & L ocation method & $\mathrm{N}$ & Interpolated from digital map. & \\
\hline LocM th & Location method & $\mathrm{P}$ & Published. Thin section location method taken from LA N L Report LA-UR-03-1503 (2003). & $\begin{array}{l}\text { http://www.pggdb- } \\
\text { swnvf.lanl.gov/ }\end{array}$ \\
\hline LocM th & Location method & $\mathrm{R}$ & Reported. & \\
\hline
\end{tabular}


Table A1. Description of Rock-Sample Database field contents.-Continued

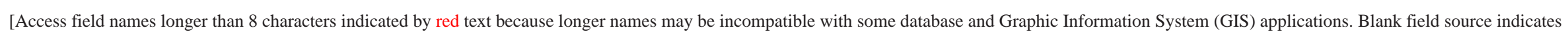

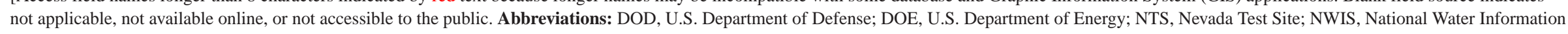
System; USGS, U.S. Geological Survey; ft, foot; - , not applicable]

\begin{tabular}{|c|c|c|c|c|}
\hline Access field name & Excel field name & Field code & Field explanation & Field source \\
\hline LocM th & Location method & S & $\begin{array}{l}\text { Transit, theodolite, or other surveying method. Thin section location method is "M " in LA NL R eport } \\
\text { LA-UR-03-1503 (2003). }\end{array}$ & $\frac{\text { http://www.pggdb- }}{\text { swnvf.lanl.gov/ }}$ \\
\hline LocM th & Location method & T & $\begin{array}{l}\text { Specific location within 7.5' (1:24,000 scale) topographic quadrangle unknown. Thin section location } \\
\text { method is "N" in LA NL R eport LA - UR-03-1503 (2003); description taken from report. }\end{array}$ & $\frac{\text { http://www.pggdb- }}{\text { swnvf.lanl.gov/ }}$ \\
\hline LocM th & Location method & U & Unknown. Thin section location method is “0” in LA NL Report LA-UR-03-1503 (2003). & $\frac{\text { http://www.pggdb- }}{\text { swnvf.lanl.gov/ }}$ \\
\hline LOCACC & Location accuracy & - & A ccuracy of latitude and longitude coordinates. & \\
\hline LOCACC & Location accuracy & $\mathrm{H}$ & Hundredth second. & \\
\hline LOCACC & Location accuracy & 1 & Tenth second. & \\
\hline LOCACC & Location accuracy & 5 & Half second. & \\
\hline LOCACC & Location accuracy & $\mathrm{S}$ & Second. & \\
\hline LOCACC & Location accuracy & $\mathrm{R}$ & Three seconds. & \\
\hline LOCACC & Location accuracy & $\mathrm{F}$ & Five seconds. & \\
\hline L OCA CC & Location accuracy & $\mathrm{T}$ & Ten seconds. & \\
\hline LOCA CC & L ocation accuracy & M & M inute. & \\
\hline LOCACC & Location accuracy & $\mathrm{U}$ & Unknown. & \\
\hline DecL at83 & $\begin{array}{l}\text { Decimal latitude } \\
\text { NAD } 83\end{array}$ & - & $\begin{array}{l}\text { Latitude, in decimal degrees [automatically generated by the N W IS system software]; N orth } \\
\text { A merican Datum of } 1983 \text { (NAD 83). }\end{array}$ & \\
\hline DecL ng83 & $\begin{array}{l}\text { Decimal longitude } \\
\text { NAD } 83\end{array}$ & - & $\begin{array}{l}\text { L ongitude, in decimal degrees [automatically generated by NW IS system software]; N orth A merican } \\
\text { Datum of } 1983 \text { (NA D 83). }\end{array}$ & \\
\hline UTME27m & $\begin{array}{l}\text { UTM Easting NAD27 } \\
\text { (meters) }\end{array}$ & - & $\begin{array}{l}\text { U niversal Transverse M ercator coordinates, Easting, zone 11, in meters; N orth A merican D atum of } \\
1927 \text { (NAD 27). }\end{array}$ & \\
\hline UTM N 27m & $\begin{array}{l}\text { UTM Northing } \\
\text { NAD27 (meters) } \\
\end{array}$ & - & $\begin{array}{l}\text { U niversal Transverse M ercator coordinates, N orthing, zone 11, in meters; N orth A merican Datum of } \\
1927 \text { (NA D 27). }\end{array}$ & \\
\hline UTMErr & UTM error & - & $\begin{array}{l}\text { UTM error, in meters. Blank if unknown. [This value within the LANL PGG database is the combined } \\
\text { uncertainty in meters for easting and northing. Thin section UTM error updated from LANL Report } \\
\text { LA-UR-03-1503 (2003)]. }\end{array}$ & $\frac{\text { http://www.pggdb- }}{\text { swnvf.lanl.gov/ }}$ \\
\hline R mk & Remarks & - & Pertinent remarks pertaining to the rock sample. & \\
\hline DtRcdL stUpd & $\begin{array}{l}\text { Date record last } \\
\text { updated }\end{array}$ & - & $\begin{array}{l}\text { Date of data entry (compiled into electronic format) is listed if a row of record has not been modified. } \\
\text { The date of last (most recent) update is listed if a row of record has been modified. This date does } \\
\text { not indicate which columns of data have been modified; only that records have been updated within } \\
\text { a particular row. Dates are listed as yyyymmdd (4-digit year; 2-digit month; } \\
\text { 2-digit day). }\end{array}$ & \\
\hline URLAdr & URL address & - & Link to online website and database. & \\
\hline
\end{tabular}


Digitally Available Interval-Specific Rock-Sample Data Compiled from Historical Records, Nevada Test Site, Nevada

This page left intentionally blank 


\section{Appendix B. Lithologic-Description Database, Nevada Test Site and Vicinity, Nye County, Nevada}

L ithologic-description data were compiled for both underground and surface sites located on and around the NTS. A ppendix B data are available at URL: http://pubs. usgs.gov/ds/2007/297/.

Table B1. Description of Lithologic-Description Database field contents.

[A ccess field names longer than 8 characters indicated by red text because longer names may be incompatible with some database and Graphic Information System (GIS) applications. Blank field source indicates not applicable, not available online, or not accessible to the public. Abbreviations: DOD, U.S. Department of Defense; DOE, U.S. Department of Energy; NTS, N evada Test Site; NWIS, N ational Water Information System; USGS, U.S. Geological Survey; ft, foot; -, not applicable]

\begin{tabular}{|c|c|c|c|c|}
\hline Access field name & Excel field name & Field code & Field explanation & Field source \\
\hline SrtOrdUSGS & USGS NTS sort order & - & $\begin{array}{l}\text { E mplacement and exploratory holes typically are displayed together. M any sites also have multiple } \\
\text { completion intervals within the same hole. Therefore, a sort order number is assigned to all USGS } \\
\text { sites associated with DOE and/or DOD projects in Nevada. This field is modified as new sites are } \\
\text { added. }\end{array}$ & \\
\hline UnqNoUSGS & $\begin{array}{l}\text { USGS NTS unique } \\
\text { number }\end{array}$ & - & $\begin{array}{l}\text { Spatial }(X-Y) \text { coordinates are unavailable at some locations. Therefore, USG S site identification } \\
\text { numbers cannot be established in the USGS NWIS database Sitefile for these sites. B ecause N WIS } \\
\text { site identification numbers cannot be assigned to all sites, it is necessary to assign a unique site } \\
\text { number to all USGS sites associated with USGS DOE/D OD projects in Nevada. A lthough the } \\
\text { unique numbers were initially assigned in the same order as the USGS NTS sort order, new sites } \\
\text { are assigned the next available sequential number. }\end{array}$ & \\
\hline NTSA rea & NTS area & - & $\begin{array}{l}\text { NTS A dministrative A rea number (see fig. 1). Entries are listed in bold type where sites are located in } \\
\text { areas other than the hole name implies. For example, USGS hole name UE -17c E leana is actually } \\
\text { located in NTS area } 04 \text {. }\end{array}$ & \\
\hline HleN meUSGS & USGS hole name & - & $\begin{array}{l}\text { USGS hole name designation. Entries are listed in bold type where sites are located in areas other } \\
\text { than the hole name implies. }\end{array}$ & \\
\hline LthlntNo & $\begin{array}{l}\text { Lithologic interval } \\
\text { number }\end{array}$ & - & Sequence of lithologic interval. & \\
\hline L thlntSeq & $\begin{array}{l}\text { Lithologic interval } \\
\text { sequence number }\end{array}$ & - & Sequence of descriptions, when multiple descriptions are reported within a lithologic interval. & \\
\hline Lthl ntTopft & $\begin{array}{l}\text { Lithologic interval } \\
\text { top (ft) }\end{array}$ & - & $\begin{array}{l}\text { D epth to top of lithologic interval; in feet below land surface for boreholes and shafts; in feet from } \\
\text { portal opening for tunnels and drifts. }\end{array}$ & \\
\hline Lthl ntB tmft & $\begin{array}{l}\text { Lithologic interval } \\
\text { bottom (ft) }\end{array}$ & - & $\begin{array}{l}\text { D epth to bottom of lithologic interval; in feet below land surface for boreholes and shafts; in feet } \\
\text { from portal opening for tunnels and drifts. }\end{array}$ & \\
\hline SmpLogTyp & Sample or log type & - & Type of sample or log that lithologic description is based upon. & \\
\hline SmpL ogTyp & Sample or log type & B asket & - & \\
\hline SmpL ogTyp & Sample or log type & $\begin{array}{c}\text { Binocular } \\
\text { microscope }\end{array}$ & - & \\
\hline
\end{tabular}


38 Digitally Available Interval-Specific Rock-Sample Data Compiled from Historical Records, Nevada Test Site, Nevada

Table B1. Description of Lithologic-Description Database field contents.-Continued

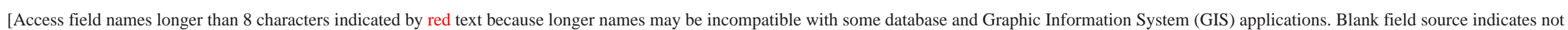

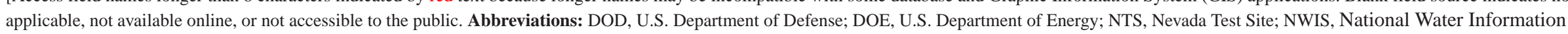
System; USGS, U.S. Geological Survey; ft, foot; - , not applicable]

\begin{tabular}{|c|c|c|c|c|}
\hline Access field name & Excel field name & Field code & Field explanation & Field source \\
\hline SmpL ogTyp & Sample or log type & Bit & - & \\
\hline SmpL ogTyp & Sample or log type & Core & - & \\
\hline SmpL ogTyp & Sample or log type & \begin{tabular}{|c|}
$\begin{array}{c}\text { Core and } \\
\text { Cuttings }\end{array}$ \\
\end{tabular} & - & \\
\hline SmpL ogTyp & Sample or log type & $\begin{array}{l}\text { Core and } \\
\text { Geophysical } \\
\log \end{array}$ & - & \\
\hline SmpL ogTyp & Sample or log type & $\begin{array}{c}\text { Core and M ovie } \\
\log \end{array}$ & - & \\
\hline SmpL ogTyp & Sample or log type & \begin{tabular}{|c|}
$\begin{array}{c}\text { Core and } \\
\text { Sidewall }\end{array}$ \\
\end{tabular} & - & \\
\hline SmpL ogTyp & Sample or log type & $\begin{array}{r}\text { Core, Sidewall, } \\
\text { and Cuttings }\end{array}$ & - & \\
\hline SmpL ogTyp & Sample or log type & Cuttings & - & \\
\hline SmpL ogTyp & Sample or log type & $\begin{array}{l}\text { Cuttings and } \\
\text { Geophysical } \\
\log \end{array}$ & - & \\
\hline SmpL ogTyp & Sample or log type & $\begin{array}{r}\text { Cuttings and } \\
\text { M ovie log }\end{array}$ & - & \\
\hline SmpL ogTyp & Sample or log type & Field notes & - & \\
\hline SmpL ogTyp & Sample or log type & Geophysical log & - & \\
\hline SmpL ogTyp & Sample or log type & Grab & - & \\
\hline SmpL ogTyp & Sample or log type & Movie log & - & \\
\hline SmpL ogTyp & Sample or log type & None & - & \\
\hline SmpL ogTyp & Sample or log type & Sidewall & - & \\
\hline SmpL ogTyp & Sample or log type & $\begin{array}{r}\text { Sidewall \& } \\
\text { Cuttings } \\
\end{array}$ & - & \\
\hline SmpL ogTyp & Sample or log type & $\begin{array}{l}\text { Sidewall \& } \\
\text { Geophysical } \\
\log \end{array}$ & - & \\
\hline SmpL ogTyp & Sample or log type & $\begin{array}{l}\text { Sidewall \& } \\
\text { M ovie log }\end{array}$ & - & \\
\hline SmpL ogTyp & Sample or log type & Thin section & - & \\
\hline
\end{tabular}


Table B1. Description of Lithologic-Description Database field contents.-Continued

[A ccess field names longer than 8 characters indicated by red text because longer names may be incompatible with some database and Graphic Information System (GIS) applications. Blank field source indicates not applicable, not available online, or not accessible to the public. Abbreviations: DOD, U.S. Department of Defense; DOE, U.S. Department of Energy; NTS, N evada Test Site; NWIS, N ational Water Information System; USGS, U.S. Geological Survey; ft, foot; - , not applicable]

\begin{tabular}{|c|c|c|c|c|}
\hline Access field name & Excel field name & Field code & Field explanation & Field source \\
\hline SmpL ogTyp & Sample or log type & Unknown & - & \\
\hline LthDsc & Lithologic description & - & $\begin{array}{l}\text { Entire lithologic description verbatim. The intent is to offer the most comprehensive (usually the } \\
\text { original) description available. Core and sidewall samples always take precedence over cuttings } \\
\text { descriptions. M ultiple descriptions exist for many holes. How ever, subsequent descriptions are } \\
\text { abridged and important alteration and structural inferences are lost. A lthough stratigraphic units } \\
\text { are frequently updated and lithologies are occasionally modified, original descriptions still take } \\
\text { precedence because cuttings samples were interpreted with the aid of binocular microscopes and } \\
\text { questionable core samples were interpreted from thin sections utilizing petrographic microscopes } \\
\text { (and occasionally spectrographic analysis). }\end{array}$ & \\
\hline GeoUntUSGSNWIS & $\begin{array}{l}\text { USGS NWIS geologic } \\
\text { unit }\end{array}$ & - & $\begin{array}{l}\text { G eologic unit or aquifer name code stored in the G round-Water Information System (GW SI) } \\
\text { subsystem of the USGS N W IS Ingress database. For example: [110V L FL - Q uaternary valley } \\
\text { fill; 121A M TK - Tertiary A mmonia Tanks M ember; 121RR M S - Tertiary Rainier M esa M ember; } \\
\text { 122PBRS - Tertiary Paintbrush Tuff; 327ELEN - Pennsylvanian Eleana Formation; 331CN M N - } \\
\text { M ississippian Chainman Shale; 344NEV D - D evonian N evada Formation; 361EURK - Ordovician } \\
\text { Eureka Q uartzite; and 400SR LG - Precambrian Stirling Quartzite]. A complete list of codes is } \\
\text { included in the nv_geo_unt worksheet in the nts_Ith_dsc spreadsheet (appendix B). }\end{array}$ & \\
\hline L thU ntU SGSN WIS & $\begin{array}{l}\text { USGS NWIS } \\
\text { lithologic unit }\end{array}$ & - & $\begin{array}{l}\text { L ithologic unit code stored in the GWSI database. For example: [A LVM - alluvium; CLAY - clay; } \\
\text { DLM T - dolomite; GRVL - gravel; LM SN - limestone; QRTZ - quartzite; SA ND - sand; } \\
\text { SHLE - shale; and TUFF - tuff]. A complete list of codes is included in the lith_unt worksheet in } \\
\text { the nts_Ith_dsc spreadsheet (appendix B). }\end{array}$ & \\
\hline CntUntUSGSNWIS & \begin{tabular}{|l}
$\begin{array}{l}\text { USGS NWIS } \\
\text { contributing unit }\end{array}$ \\
\end{tabular} & - & Contributing unit code stored in the GWSI database. & \\
\hline CntU ntU SGSNWIS & $\begin{array}{l}\begin{array}{l}\text { USGS NWIS } \\
\text { contributing unit }\end{array} \\
\end{array}$ & $\mathrm{N}$ & Contributes no water. & \\
\hline CntU ntU SGSNWIS & $\begin{array}{l}\text { USGS NWIS } \\
\text { contributing unit }\end{array}$ & $P$ & Principal contributing aquifer (only one per site). & \\
\hline CntU ntU SGSN WIS & $\begin{array}{l}\text { USGS NWIS } \\
\text { contributing unit }\end{array}$ & Q & A ggregate of lithologic units. & \\
\hline CntU ntU SGSNWIS & $\begin{array}{l}\text { USGS NWIS } \\
\text { contributing unit }\end{array}$ & $\mathrm{S}$ & Secondary contributing aquifer. & \\
\hline CntU ntU SGSNWIS & $\begin{array}{l}\text { USGS NWIS } \\
\text { contributing unit }\end{array}$ & U & Unknown contribution. & \\
\hline
\end{tabular}


Table B1. Description of Lithologic-Description Database field contents.-Continued

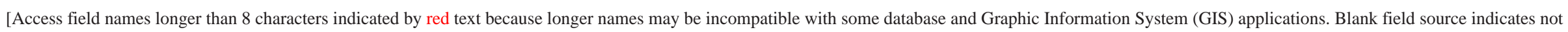

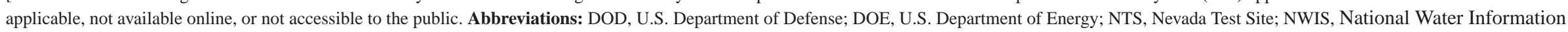
System; USGS, U.S. Geological Survey; ft, foot; -, not applicable]

\begin{tabular}{|c|c|c|c|c|}
\hline Access field name & Excel field name & Field code & Field explanation & Field source \\
\hline M apUntSym & M ap unit symbol & - & $\begin{array}{l}\text { A list of map unit symbols commonly used at the NTS and vicinity are provided. For example: } \\
\text { [QTa - middle Pleistocene to late Tertiary alluvial deposits; Tac - M iocene Calico Hills Formation; } \\
\text { Tbgr - Tertiary crystal-rich Grouse Canyon Tuff; Tcpk - Tertiary R hyolite of K earsarge; TnA BCD } \\
\text { - Tertiary Tunnel Formation, } 4 \text { M ember, beds 4A, 4B, 4C, and 4D; Oaa - Ordovician A ntelope } \\
\text { Valley Limestone, Aysees Peak M ember; and Dg - upper and middle Devonian Guilmette } \\
\text { Formation]. A complete list of codes is included in the map_unt worksheet in the nts_lith_dsc } \\
\text { spreadsheet (appendix B). }\end{array}$ & \\
\hline LthGrp & Lithologic group & - & $\begin{array}{l}\text { A list of one-three character codes is provided to specify general rock types. For example: [lim - } \\
\text { igneous, intrusive, mafic; Sc - sedimentary, consolidated; and M - M etamorphic]. A complete list } \\
\text { of codes is included in the lith_grp worksheet in the nts_lith_dsc spreadsheet (appendix B). }\end{array}$ & \\
\hline LthDscUnt & $\begin{array}{l}\text { Lithologic description } \\
\text { unit }\end{array}$ & - & $\begin{array}{l}\text { A list of three-character codes and modifiers are provided to specify detailed descriptions or } \\
\text { subdivisions of lithologic units. Codes are restricted to important features and added by } \\
\text { significance (usually order listed). M odifier usage is also minimized because fields are parsed } \\
\text { to construct graphical plots. O ne- to two-character codes are followed by one or two spaces to } \\
\text { maintain the three-character length. For example: [air - air-fall/ash-fall tuff; ash - ash-flow tuff; bed } \\
\text { - bedded tuff; dwt - densely welded tuff; fls - felsite; nwt - nonwelded tuff; lac - lacustrine deposits; } \\
\text { pd - playa deposits; pum - pumice; and vtp - vitrophyre]. A complete list of codes is included in the } \\
\text { lith dsc worksheet in the nts Ith dsc spreadsheet (appendix B). }\end{array}$ & \\
\hline L thChrUnt & $\begin{array}{l}\text { Lithologic } \\
\text { characteristics unit }\end{array}$ & - & $\begin{array}{l}\text { A list of three-character codes and modifiers are provided to specify diagnostic features of lithologic } \\
\text { units. Codes are restricted to important features and added by significance (usually order listed). } \\
\text { M odifier usage is also minimized because fields are parsed to construct graphical plots. O ne- to } \\
\text { two-character codes are followed by one or two spaces to maintain the three-character length. For } \\
\text { example: [arz - argillaceous; chl - chloritic; dvt - devitrified; fct - fractured; hxt - holocrystalline; } \\
\text { ind - indurated; mrd - mordenite; Ol - Olivine; slc - silicic; vit - vitric; and zeo - zeolitic]. A } \\
\text { complete list of codes is included in the lith_chr worksheet in the nts_lth_dsc spreadsheet } \\
\text { (appendix B). }\end{array}$ & \\
\hline LthHydUnt & Lithohydrologic unit & - & $\begin{array}{l}\text { A list of codes is provided to specify general terms for aquifers or confining units. For example: [ICA } \\
\text { - lower-carbonate aquifer; ICICU - lower-clastic confining unit; ucICU - upper-clastic confining } \\
\text { unit; vA - volcanic aquifer; vCU - volcanic confining unit; and vfA - valley-fill aquifer]. A } \\
\text { complete list of codes is included in the lith_hyd_unt worksheet in the nts_Ith_dsc spreadsheet } \\
\text { (appendix B). }\end{array}$ & \\
\hline L thR mk & Lithologic remarks & - & $\begin{array}{l}\text { Comments pertaining to lithologic-interval descriptions. Currently used mostly to house } \\
\text { stratigraphic/lithologic references included with written descriptions; these data are utilized as } \\
\text { an aid for populating the USGS NW IS geologic unit, USGS NW IS lithologic unit, USGS NWIS } \\
\text { contributing unit, M ap unit symbol, L ithologic description unit, L ithologic characteristics unit, and } \\
\text { Lithohydrologic unit fields. }\end{array}$ & \\
\hline
\end{tabular}


Table B1. Description of Lithologic-Description Database field contents.—Continued

[A ccess field names longer than 8 characters indicated by red text because longer names may be incompatible with some database and Graphic Information System (GIS) applications. Blank field source indicates not applicable, not available online, or not accessible to the public. A bbreviations: DOD, U.S. Department of Defense; DOE, U.S. Department of Energy; NTS, Nevada Test Site; NWIS, National Water Information System; USGS, U.S. Geological Survey; ft, foot; - , not applicable]

\begin{tabular}{|c|c|c|c|c|}
\hline Access field name & Excel field name & Field code & Field explanation & Field source \\
\hline OFROrdUSGS97139 & $\begin{array}{l}\text { USGS O pen-File } \\
\text { Report 97-139 } \\
\text { order }\end{array}$ & - & N umerical order site is listed in USGS O pen-File Report 97-139. & \\
\hline OFRHIelDUSGS97139 & $\begin{array}{l}\text { USGS O pen-File } \\
\text { Report 97-139 Hole } \\
\text { ID }\end{array}$ & - & $\begin{array}{l}\text { Hole name listed in USGS Open-File Report 97-139. Entries are listed in bold type where sites are } \\
\text { located in areas other than the hole name implies. }\end{array}$ & \\
\hline DatSrc & Data source & - & A gency that reported lithologic-description data. & \\
\hline DatSrc & Data source & AML & A nalytical M aterials L aboratory (A M L), 3463 State Street, \#349, Santa B arbara, California. & \\
\hline DatSrc & Data source & $\mathrm{BN}$ & B echtel N evada (BN). & \\
\hline DatSrc & Data source & DTRA & D OD, Defense Threat Reduction A gency (DTRA). & \\
\hline DatSrc & Data source & $F \& S$ & Fenix and Scisson, Inc. (F\&S). & \\
\hline DatSrc & Data source & FSN & Fenix and Scisson of Nevada (FSN). & \\
\hline DatSrc & Data source & IT Corp. & International Technology Corporation (IT Corp., purchased by Shaw Group, Inc.). & \\
\hline DatSrc & Data source & LANL & L os A lamos National Laboratory (LANL). & \\
\hline DatSrc & Data source & LLNL & L awrence Livermore N ational L aboratory (LLNL). & \\
\hline DatSrc & Data source & NDWR & $\begin{array}{l}\text { State of N evada, D epartment of Conservation and Natural Resources, Division of Water Resources } \\
\text { (State Engineer). }\end{array}$ & \\
\hline DatSrc & Data source & NSTec & National Security Technologies, LLC (NSTec). & \\
\hline DatSrc & Data source & RSN & Raytheon Services Nevada (RSN). & \\
\hline DatSrc & Data source & SNJV & Stoller-N avarro J oint Venture (SNJV). & \\
\hline DatSrc & Data source & USGS & USGS. & \\
\hline RcdTypDsc & $\begin{array}{c}\text { Record type or } \\
\text { description }\end{array}$ & - & Record description and/or document type. & \\
\hline RcdTypDsc & $\begin{array}{l}\text { Record type or } \\
\text { description }\end{array}$ & $\mathrm{BN} / \mathrm{PF}$ & Bechtel Nevada (BN) Project Files (PF). & \\
\hline RcdTypDsc & $\begin{array}{l}\text { Record type or } \\
\text { description }\end{array}$ & DTRA/PF & D OD, Defense Threat Reduction A gency (DTRA) Project Files (PF). & \\
\hline RcdTypDsc & $\begin{array}{l}\text { Record type or } \\
\text { description }\end{array}$ & $F \& S / P F$ & Fenix and Scisson, Inc. (F\&S) Project Files (PF). & \\
\hline RcdTypDsc & $\begin{array}{c}\text { Record type or } \\
\text { description }\end{array}$ & FSN/PF & Fenix and Scisson of Nevada (FSN) Project Files (PF). & \\
\hline RcdTypDsc & $\begin{array}{l}\text { Record type or } \\
\text { description }\end{array}$ & IT Corp./PF & International Technology Corporation (IT Corp.) Project Files (PF). & \\
\hline
\end{tabular}


Table B1. Description of Lithologic-Description Database field contents._Continued

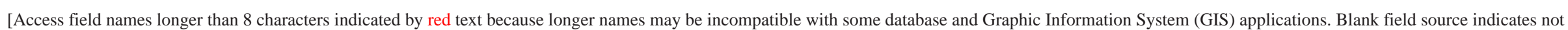

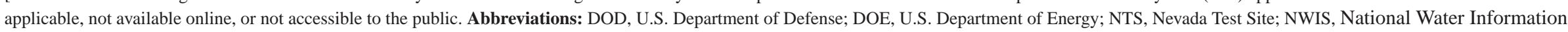
System; USGS, U.S. Geological Survey; ft, foot; -, not applicable]

\begin{tabular}{|c|c|c|c|c|}
\hline Access field name & Excel field name & Field code & Field explanation & Field source \\
\hline RcdTypDsc & $\begin{array}{c}\text { Record type or } \\
\text { description }\end{array}$ & LANL/PF & Los A lamos N ational Laboratory (LA NL) Project Files (PF); referred to as "Blue Folders." & \\
\hline RcdTypDsc & $\begin{array}{c}\text { Record type or } \\
\text { description }\end{array}$ & LLNL/PF & Lawrence Livermore National Laboratory (LLNL) Project Files (PF). & \\
\hline RcdTypDsc & $\begin{array}{c}\text { Record type or } \\
\text { description }\end{array}$ & NDWR/WDR & State of Nevada, Division of Water Resources, Well Driller's Report (Well Log). & \\
\hline RcdTypDsc & $\begin{array}{c}\text { Record type or } \\
\text { description }\end{array}$ & NSTec/PF & National Security Technologies, LLC. (NSTec) Project Files (PF). & \\
\hline RcdTypDsc & $\begin{array}{c}\text { Record type or } \\
\text { description }\end{array}$ & RSN/PF & Raytheon Services N evada (RSN) Project Files (PF). & \\
\hline RcdTypDsc & $\begin{array}{c}\text { Record type or } \\
\text { description }\end{array}$ & SNJV/PF & Stoller-N avarro J oint Venture (SNJV) Project Files (PF). & \\
\hline RcdTypDsc & $\begin{array}{c}\text { Record type or } \\
\text { description }\end{array}$ & USGS/PF & USGS Project Files (PF). & \\
\hline RptR ef & Report reference & - & $\begin{array}{l}\text { Published report that contains lithologic-description data. A complete list of acronyms and } \\
\text { abbreviations used in USGS and other reports is included in the usgs_rpt and nts_acr_abv } \\
\text { worksheets in the nts_Ith_dsc spreadsheet (appendix B). NOTE : [USG S Technical Letters } \\
\text { are considered internal correspondence and are not available for public release unless the } \\
\text { report has been assigned a USG S O pen-F ile Report number. Technical Letters prepared } \\
\text { under the USG S Hydrologic R esource M anagement Program (HR M P, formerly Hydrology/ } \\
\text { R adionuclide M igration Program) and assigned "blanket open-file status" are designated } \\
\text { "USG S-474-number." Technical Letters prepared under the USG S Yucca M ountain Program } \\
\text { (Y M P) and assigned "blanket open-file status" are designated "USG S-1543-number." } \\
\text { Furthermore, some reports prepared by the National L aboratories and the various DOE } \\
\text { and DOD subcontractors also may be considered internal correspondence and not available } \\
\text { for public release. Users interested in these reports must check with the source agency to } \\
\text { determine availability.] }\end{array}$ & \\
\hline Invst & Investigators & - & A uthors and/or investigators. & \\
\hline LocIDLANL & $\begin{array}{l}\text { LA NL PGG Database } \\
\text { loc_id }\end{array}$ & - & $\begin{array}{l}\text { This unique symbol within the LANL PGG database represents a specific, usually unique location on } \\
\text { the surface, or a specific, usually unique location within a tunnel. The dash character (-) is reserved } \\
\text { for sample IDs and therefore dashes in published locations are converted to a foreslash (/). Thus } \\
\text { 11/102/7A is the loc_id for a sample identified by its collector as 11-102-7-A. Description updated } \\
\text { from LANL Report LA-UR-03-1503 (2003). }\end{array}$ & $\frac{\text { http://www.pggdb- }}{\text { swnvf.lanl.gov/ }}$ \\
\hline
\end{tabular}


Table B1. Description of Lithologic-Description Database field contents.-Continued

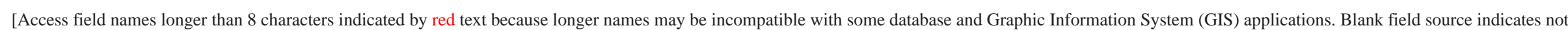

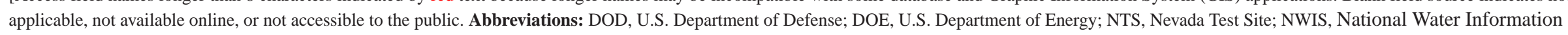
System; USGS, U.S. Geological Survey; ft, foot; -, not applicable]

\begin{tabular}{|c|c|c|c|c|}
\hline Access field name & Excel field name & Field code & Field explanation & Field source \\
\hline SamIDLANL & $\begin{array}{l}\text { LANL_PGG Database } \\
\text { sam_id }\end{array}$ & - & $\begin{array}{l}\text { This unique symbol within the LA NL PGG database represents up to a few kilograms of contiguous } \\
\text { material from the surface or subsurface. The dash special character (-) designates multiple samples } \\
\text { from a single location, and a left parenthesis '(' designates multiple splits from a single sample. } \\
\text { Samples from vertical drill holes will always have sam_id's represented by the location, which is } \\
\text { the drill hole name, followed by a dash (-) and the sample depth in feet, for example, USW G2-770. } \\
\text { Sample depths in meters attach "M " following the metric depth, for example, U SW G-506.65M. } \\
\text { M ultiple samples from the same location, for example a whole-rock sample and several lithic and } \\
\text { pumice separates, will always have sam_id's represented by the location follow ed by a dash (-) } \\
\text { and a character string, for example RW 18B 3-WR, RW 18B 3-PU 1, and RW 18B 3-PU2. D escription } \\
\text { updated from LA N R Report LA-UR-03-1503 (2003). }\end{array}$ & $\frac{\text { http://www.pggdb- }}{\underline{\text { swnvf.lanl.gov/ }}}$ \\
\hline SpIIDLANL & $\begin{array}{l}\text { LANL_PGG Database } \\
\text { spl_id }\end{array}$ & - & $\begin{array}{l}\text { This unique symbol within the LA NL PGG database represents a split of a sample for analysis. } \\
\text { A split represents analysis for one or more element or component that is performed by a single } \\
\text { laboratory. U sually, a few grams are split from the sample and specially prepared for the analytical } \\
\text { procedure, such as a glass-covered thin section for petrographic analysis or pulverized rock for } \\
\text { chemical analysis. Each thin section and each laboratory's chemical analysis represents a separate } \\
\text { split, even if the analyses are performed by different analysts on widely separated dates. Each thin } \\
\text { section represents a split, but each batch of sample pulverized for chemical analysis does not. A } \\
\text { left parenthesis '(' designates each split from a single sample, such as B H 86N/33(B, a polished } \\
\text { thin section for sample B H86N/33. M ultiple chemical analyses of the same sample by the same } \\
\text { laboratory and multiple analyses of the same thin section are considered to represent replicate } \\
\text { analyses. To represent split analyses, replicate chemical analyses are averaged, weighted by } \\
\text { the inverse square of their analytical uncertainties. Replicate petrographic analyses are ranked; } \\
\text { analyses of the same rank are averaged, weighted by the number of points counted. Individual } \\
\text { replicate analyses are not stored within the database, but analysts and analytical dates and other } \\
\text { information are provided with the analytical data. Description updated from LANL Report LA- } \\
\text { UR-03-1503 (2003). }\end{array}$ & $\frac{\text { http://ww w.pggdb- }}{\text { swnvf.lanl.gov/ }}$ \\
\hline RecL OC & Record location & - & Physical location of lithologic-description record. & \\
\hline HleTyp & Hole type & - & Type of vertical or horizontal drilling or excavation. & \\
\hline HleTyp & Hole type & Borehole & Vertical surface location; includes wells and vertical test holes. & \\
\hline HleTyp & Hole type & Crater & Vertical surface location. & \\
\hline HleTyp & Hole type & Drift & Horizontal underground location; includes tunnels and horizontal test holes. & \\
\hline HleTyp & Hole type & M ultiple wells & M ultiple wells. & \\
\hline HleTyp & Hole type & Outcrop & Surface location. & \\
\hline HleTyp & Hole type & Shaft & Vertical surface location. & \\
\hline HleTyp & Hole type & Spring & Spring. & \\
\hline HleType & Hole type & Streambed & Streambed. & \\
\hline
\end{tabular}


Table B1. Description of Lithologic-Description Database field contents.-Continued

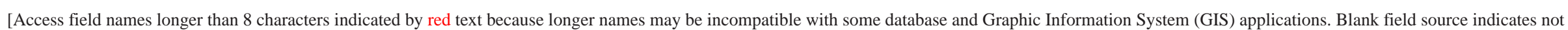

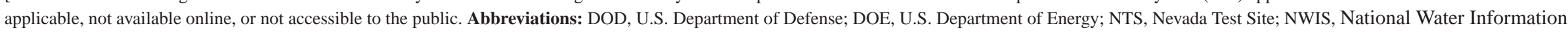
System; USGS, U.S. Geological Survey; ft, foot; - , not applicable]

\begin{tabular}{|c|c|c|c|c|}
\hline Access field name & Excel field name & Field code & Field explanation & Field source \\
\hline HleTyp & Hole type & Surface & Surface location. & \\
\hline HleTyp & Hole type & Trench & Horizontal surface location. & \\
\hline HleTyp & Hole type & Unknown & Hole type not known. & \\
\hline TnlDftConSta & $\begin{array}{l}\text { Tunnel or drift } \\
\text { construction station }\end{array}$ & - & $\begin{array}{l}\text { Construction station at collar location (portal opening), for tunnels and drifts (i.e. - } 9+17 \text { is } 917 \mathrm{ft} \text {; } \\
10+72,195 \text { ' is a } 195 \mathrm{ft} \text { hole at the } 1,072 \mathrm{ft} \text { station; etc.). }\end{array}$ & \\
\hline ConStaRmk & $\begin{array}{l}\text { Construction station } \\
\text { remarks }\end{array}$ & - & $\begin{array}{l}\text { Remarks concerning the portal opening (collar location), for tunnels and drifts (i.e. - In U -12e.14 } \\
\text { main drift; Alcove; Face; Invert; Lft Rib; Rt Rib; etc.). }\end{array}$ & \\
\hline NVSPE 27 & $\begin{array}{l}\text { Nevada SPC S Easting } \\
\text { NAD } 27\end{array}$ & - & $\begin{array}{l}\text { N evada state plane coordinates (SPCS), Easting, central zone, in feet; N orth A merican Datum of } 1927 \\
\text { (NAD 27). }\end{array}$ & \\
\hline NVSPN 27 & $\begin{array}{l}\text { N evada SPCS } \\
\text { N orthing NA D } 27\end{array}$ & - & $\begin{array}{l}\text { N evada state plane coordinates (SPCS), N orthing, central zone, in feet; N orth A merican D atum of } \\
1927 \text { (NA D27). }\end{array}$ & \\
\hline NVSPErr & SPCS error & - & SPCS error, in feet. Blank if unknown. & \\
\hline AltPorOpn29ft & $\begin{array}{l}\text { A ltitude at portal } \\
\text { opening NGVD } 29 \\
\text { (ft) }\end{array}$ & - & $\begin{array}{l}\text { A Ititude at the collar location of the portal opening, for tunnels and drifts; in feet above mean sea } \\
\text { level; N ational G eodetic Vertical Datum of } 1929 \text { (N GV D 29). }\end{array}$ & \\
\hline BngPorOpnDeg & $\begin{array}{l}\text { B earing from portal } \\
\text { opening (degrees) }\end{array}$ & - & $\begin{array}{l}\text { B earing from the portal opening, for tunnels and drifts; in degrees, minutes, and seconds or decimal } \\
\text { degrees (i.e. - S0720958W is South, } 72 \text { degrees, } 9 \text { minutes, } 58 \text { seconds West; N 0325529E is N orth, } \\
32 \text { degrees, } 55 \text { minutes, } 29 \text { seconds East; N 052.75W is North } 52 \text { and three-quarter degrees West; } \\
\text { etc.) }\end{array}$ & \\
\hline IncPorOpnD eg & $\begin{array}{c}\text { Inclination from portal } \\
\text { opening (degrees) }\end{array}$ & - & $\begin{array}{l}\text { Inclination from the portal opening, for tunnels and drifts; in degrees, minutes, and seconds or } \\
\text { decimal degrees (i.e. - } 0045825 \text { is a hole } 4 \text { degrees, } 58 \text { minutes, } 25 \text { seconds above horizontal; } \\
2700000 \text { is a vertical hole below horizontal; } 0900000 \text { is a vertical hole above horizontal; } 0000000 \\
\text { and } 1800000 \text { are horizontal holes; } 0150000 \text { and } 1650000 \text { are holes } 15 \text { degrees up (above } \\
\text { horizontal); } 3150000 \text { and } 2250000 \text { are holes } 45 \text { degrees down (bel ow horizontal); } 356.5 \text { is a hole } \\
3 \text { and one-half degrees below horizontal; } 170.25 \text { is } 9 \text { and three-quarter degrees above horizontal; } \\
\text { etc.). Inclinations are linked to bearings, so values near horizontal for holes bearing north or } \\
\text { east would be added to zero for holes inclined above horizontal and subtracted from } 360 \text { for } \\
\text { holes below horizontal; conversely, values near horizontal for holes bearing south or west would } \\
\text { be subtracted from } 180 \text { for holes inclined above horizontal and added to } 180 \text { for holes bel ow } \\
\text { horizontal. }\end{array}$ & \\
\hline AltL ndSur29ft & $\begin{array}{l}\text { A ltitude of land } \\
\text { surface NG V D29 } \\
\text { (ft) }\end{array}$ & - & $\begin{array}{l}\text { A Ititude of land surface within a reasonable proximity of the site; in feet above mean sea level; } \\
\text { N ational G eodetic Vertical D atum of } 1929 \text { (N GV D 29). This is an average of the surrounding } \\
\text { ground-surface elevation. If the original surface has been altered, estimate the altitude based on } \\
\text { nearby unal tered terrain. }\end{array}$ & \\
\hline AltM th & Altitude method & - & M ethod used to determine altitude of land surface. & \\
\hline
\end{tabular}


Table B1. Description of Lithologic-Description Database field contents.-Continued

[A ccess field names longer than 8 characters indicated by red text because longer names may be incompatible with some database and Graphic Information System (GIS) applications. Blank field source indicates not applicable, not available online, or not accessible to the public. Abbreviations: DOD, U.S. Department of Defense; DOE, U.S. Department of Energy; NTS, N evada Test Site; NWIS, N ational Water Information System; USGS, U.S. Geological Survey; ft, foot; - , not applicable]

\begin{tabular}{|c|c|c|c|c|}
\hline Access field name & Excel field name & Field code & Field explanation & Field source \\
\hline AltM th & Altitude method & A & Altimeter. & \\
\hline AltM th & Altitude method & $\mathrm{D}$ & Differentially-corrected Global Positioning System (DGPS). & \\
\hline A ltM th & Altitude method & G & Global Positioning System (GPS). & \\
\hline AltM th & Altitude method & I & Interferometric Synthetic A perture Radar (IfSA R), airplane. & \\
\hline A ItM th & Altitude method & J & Light Detection A nd Ranging (LiDA R), airplane. & \\
\hline AltM th & Altitude method & $\mathrm{L}$ & L evel or other surveying method. & \\
\hline AltM th & Altitude method & M & $\begin{array}{l}\text { Interpolated from topographic map [report accuracy as } \pm \text { one-half the contour interval (or } \\
\text { supplementary contour interval) specified on the quadrangle]. }\end{array}$ & \\
\hline A ItM th & Altitude method & $\mathrm{N}$ & Interpolated from digital elevation model (DEM). & \\
\hline AltM th & Altitude method & $\mathrm{R}$ & Reported. & \\
\hline A ItM th & Altitude method & $\mathrm{U}$ & Unknown. & \\
\hline A ItA $c c$ & Altitude accuracy & - & A ltitude accuracy; in feet (decimal values for accuracies less than $1 \mathrm{ft}$ ). & \\
\hline A It A CC & Altitude accuracy & $\mathrm{U}$ & Unknown. & \\
\hline SitC mpDt & Site completion date & - & Date hole construction completed. & \\
\hline HleD thft & Hole depth (ft) & - & $\begin{array}{l}\text { H ole depth; in feet below land surface for boreholes and shafts; in feet from portal opening for } \\
\text { tunnels and drifts. }\end{array}$ & \\
\hline RedBkHleNo & Redbook hole number & - & $\begin{array}{l}\text { Redbook hole numbers are currently assigned to new holes completed at the NTS by National } \\
\text { Security Technologies, L LC (NSTec). Entries are listed in bold type where sites are located in } \\
\text { areas other than the hole name implies. }\end{array}$ & \\
\hline
\end{tabular}


Table B1. Description of Lithologic-Description Database field contents.-Continued

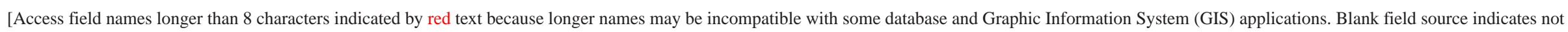

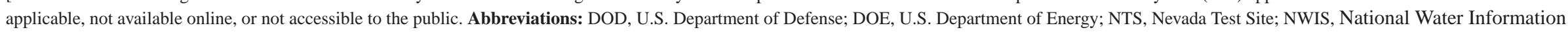
System; USGS, U.S. Geological Survey; ft, foot; -, not applicable]

\begin{tabular}{|c|c|c|c|c|}
\hline Access field name & Excel field name & Field code & Field explanation & Field source \\
\hline RedB kHleNo & Redbook hole number & - & $\begin{array}{l}\text { Redbook hole numbers listed in the Raytheon Services N evada (RSN) N evada Test Site D rilling and } \\
\text { M ining Summary (last updated 12-31-90) and previously in the F enix and Scisson of N evada NTS } \\
\text { Drilling and M ining Summary (last updated 06-30-89; formerly Fenix and Scisson, Inc.) were } \\
\text { assigned according to the type of hole drilled or mined, site location (NTS area), and sequence } \\
\text { code for the consecutive order in which the hole was drilled, mined, or recompleted. Emplacement } \\
\text { holes for nuclear weapons tests begin with the letter U, follow ed by a dash (-), NTS area number } \\
\text { (fig. 1), and sequence code (letters a-z, aa-az, ba-bz, ..., za-zz). Exploratory holes follow the } \\
\text { same naming convention as emplacement holes, but begin with the letters UE. H oles that begin } \\
\text { with the letter U but w ere drilled or mined specifically to provide data that could not be collected } \\
\text { from an emplacement hole follow the emplacement hole naming convention, but are assigned } \\
\text { incremental letters or numbers, or both following the sequence code. The suffix letters indicate: } \\
\text { [\#, satellite hole; CH, cable hole; Ex. or Expl., exploratory hole; HTH, hydrologic test hole; Inst., } \\
\text { instrument hole; ITS, integrated test system; PPS, pre-postshot hole; PS, post-shot hole; R N M, } \\
\text { radionuclide migration hole; RW M S, radioactive waste management site; and S, substitute hole]. } \\
\text { There are numerous exceptions to the standard naming convention. The prefix letters indicate: } \\
\text { [HTH, hydrologic test hole; J, Jackass Flat; and R N M, radionuclide migration]. N umbers and } \\
\text { letters following the dash in the exceptions represent sequence of site drilling or mining, not NTS } \\
\text { location. Hole type al so is commonly listed after the hole designation. For example: [Access } \\
\text { Shaft; Cable Hole; Expl. Hole; Instrument; L OS (Line Of Sight) Drift; Sidetrack; R eentry M ining; } \\
\text { Tunnel; Vent Hole; and Zero Station]. }\end{array}$ & \\
\hline RedB kH leNo & Redbook hole number & - & $\begin{array}{l}\text { USGS DOE project-related holes in Central N evada follow a similar naming convention. However } \\
\text { emplacement holes begin with the letters UC and exploratory holes begin with the letters UCE. }\end{array}$ & \\
\hline RedB kHleNo & Redbook hole number & - & $\begin{array}{l}\text { USGS Y ucca M ountain Project (Y M P) holes at the NTS follow the exploratory hole naming } \\
\text { convention. Offsite Y M P holes begin with the letters U SW to indicate underground southern } \\
\text { N evada waste. The suffix letters indicate: [G, geologic hole; GA, geologic angle hole; GU, } \\
\text { geologic unsaturated zone hole; H, hydrologic hole; M X, missile-experimental hole (drilled } \\
\text { for U.S. A ir Force [USA F] M X M issile-Siting Investigation); N, neutron hole; p, Pal eozoic or } \\
\text { pre-Tertiary hole; RF, repository facility hole; UZ, unsaturated zone hole; V, volcanic hole; V SE, } \\
\text { vertical shelter exploratory hole (drilled for USA F M X M issile-Siting Investigation); and WT, } \\
\text { water table hole]. }\end{array}$ & \\
\hline RedB kHleNo & R edbook hole number & - & $\begin{array}{l}\text { Environmental Restoration Program (ERP) holes at the NTS begin with the letters ER, followed by } \\
\text { a dash, NTS area number (fig. 1), a dash, and an incremental sequence number. The NTS area } \\
\text { number is replaced by suffix letters for ERP holes located offsite. The suffix letters indicate: [EC, } \\
\text { area at the USA F N ellis A ir Force B ase Range (NA FBR) where the holes were drilled; and OV, } \\
\text { Oasis Valley]. }\end{array}$ & \\
\hline
\end{tabular}


Table B1. Description of Lithologic-Description Database field contents.-Continued

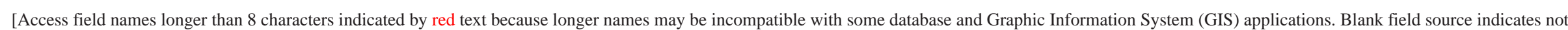

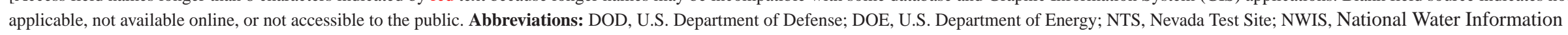
System; USGS, U.S. Geological Survey; ft, foot; -, not applicable]

\begin{tabular}{|c|c|c|c|c|}
\hline Access field name & Excel field name & Field code & Field explanation & Field source \\
\hline RedB kHleNo & Redbook hole number & - & 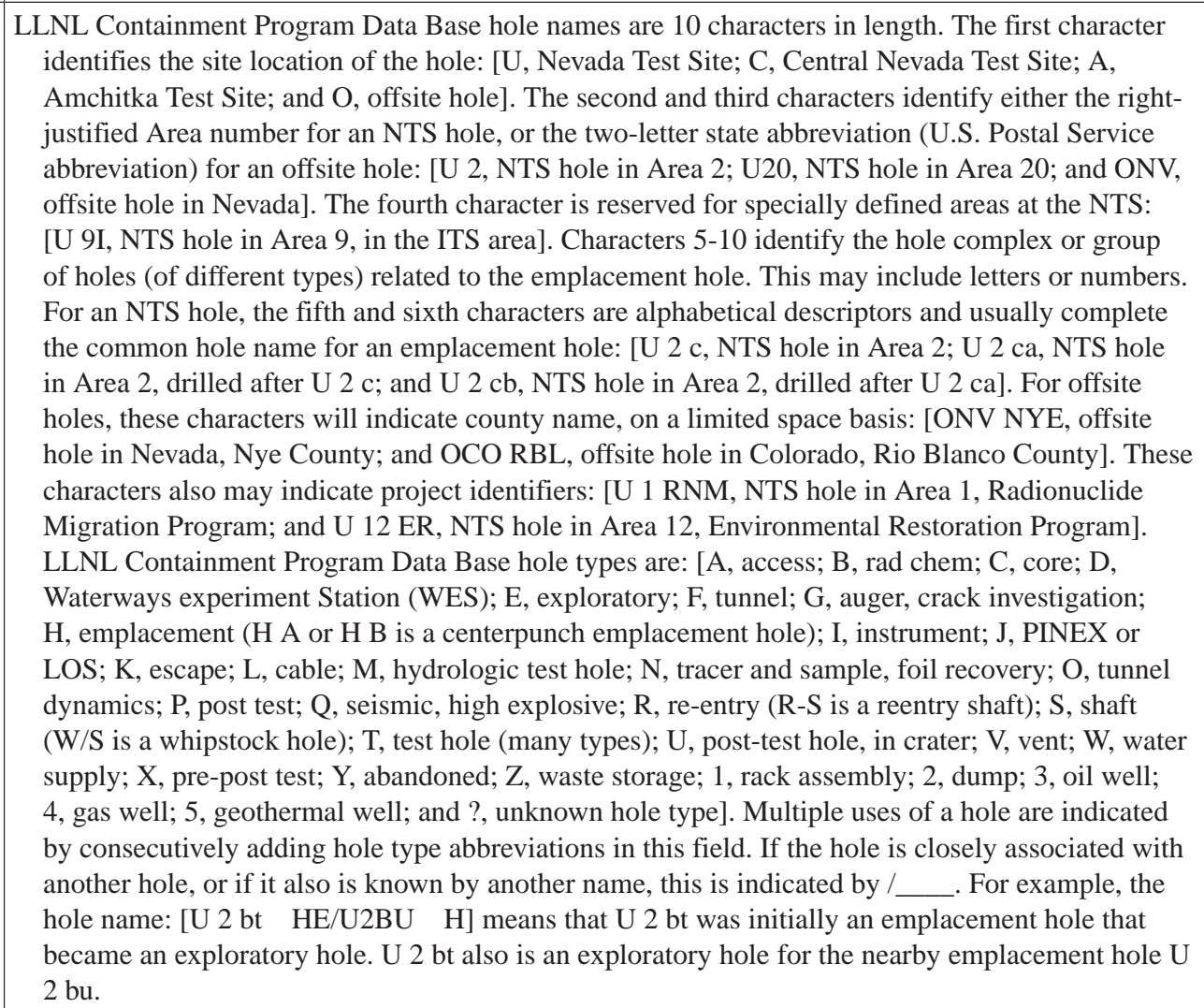 & \\
\hline FmrOthH leN me & $\begin{array}{l}\text { Former or other hole } \\
\text { name }\end{array}$ & - & Former or other names utilized for holes. & \\
\hline A gyCdU SGSNWIS & NWIS agency code & USGS & $\begin{array}{l}\text { USGS N WIS code to indicate the reporting agency. A II sites currently populated in the lithologic- } \\
\text { description database are assigned as USGS. }\end{array}$ & \\
\hline SitIDNOUSGSNWIS & $\begin{array}{c}\text { NW IS site } \\
\text { identification } \\
\text { number }\end{array}$ & - & USGS NWIS site identification number. & \\
\hline
\end{tabular}


Table B1. Description of Lithologic-Description Database field contents.-Continued

[A ccess field names longer than 8 characters indicated by red text because longer names may be incompatible with some database and Graphic Information System (GIS) applications. B lank field source indicates not applicable, not available online, or not accessible to the public. A bbreviations: DOD, U.S. Department of Defense; DOE, U.S. Department of Energy; NTS, Nevada Test Site; NWIS, National Water Information System; USGS, U.S. Geological Survey; ft, foot; -, not applicable]

\begin{tabular}{|c|c|c|c|c|}
\hline Access field name & Excel field name & Field code & Field explanation & Field source \\
\hline SitIDN oUSGSNWIS & $\begin{array}{l}\text { NW IS site } \\
\text { identification } \\
\text { number }\end{array}$ & - & $\begin{array}{l}\text { Downstream order numbers are assigned for surface-water, on-stream, sites. The first two digits of the } \\
\text { station number indicate the part or major drainage system formerly used for USGS Water-Supply } \\
\text { Papers entitled "Surface Water Supply of the United States" and the remaining digits indicate } \\
\text { the downstream order within the part. This site number is left-justified. A Ithough downstream } \\
\text { identification numbers have been converted to a variable length format, with up to } 14 \text { digits } \\
\text { available, } 8 \text { digits are normally assigned. }\end{array}$ & \\
\hline SitIDN oUSGSNWIS & $\begin{array}{l}\text { NWIS site } \\
\text { identification } \\
\text { number }\end{array}$ & - & $\begin{array}{l}\text { Numbering system for sites on open water bodies, off-channel sites, wells, springs, etc., is based } \\
\text { on the grid system of latitude and longitude. A lthough this number is initially determined from } \\
\text { the best known latitude/longitude location, plus a 2-digit sequence number for the number of } \\
\text { sites located at those coordinates, it retains no locational relevance once the site is created in the } \\
\text { database. The overall designation consists of } 15 \text { digits. The values of latitude and longitude are } \\
\text { updated as better coordinates become available, and should al ways be used for locating sites or } \\
\text { plotting locations. }\end{array}$ & \\
\hline Lat27 & Latitude NA D 27 & - & $\begin{array}{l}\text { L atitude; in degrees, minutes, and seconds [two digits are available for decimal seconds]; N orth } \\
\text { A merican Datum of } 1927 \text { (NA D 27). }\end{array}$ & \\
\hline Lng27 & Longitude NAD 27 & - & $\begin{array}{l}\text { Longitude; in degrees, minutes, and seconds [two digits are available for decimal seconds]; North } \\
\text { A merican D atum of } 1927 \text { (NAD 27). }\end{array}$ & \\
\hline LoCM th & Location method & - & M ethod used to determine latitude and Iongitude coordinates. & \\
\hline LocM th & Location method & $\mathrm{C}$ & Calculated from land net. & \\
\hline LocM th & Location method & $\mathrm{D}$ & Differentially-corrected Global Positioning System (DGPS). & \\
\hline LocM th & Location method & G & $\begin{array}{l}\text { Global positioning system (GPS), uncorrected [Standard Positioning Service (SPS) and Precise } \\
\text { Positioning Service (PPS)]. }\end{array}$ & \\
\hline LocM th & Location method & $\mathrm{L}$ & L ong-range navigation (L oran) system. & \\
\hline LocM th & Location method & M & Interpolated from map. & \\
\hline LocM th & Location method & $\mathrm{N}$ & Interpolated from digital map. & \\
\hline LoCM th & Location method & $\mathrm{R}$ & Reported. & \\
\hline LOCM th & Location method & $\mathrm{S}$ & Transit, theodolite, or other surveying method. & \\
\hline
\end{tabular}


Table B1. Description of Lithologic-Description Database field contents.-Continued

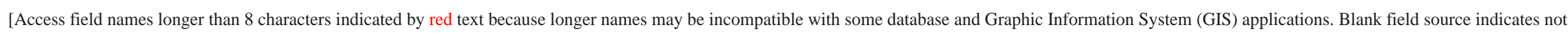

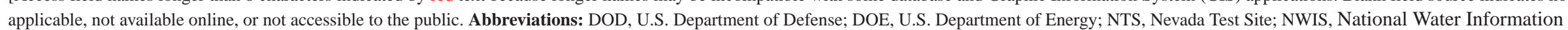
System; USGS, U.S. Geological Survey; ft, foot; - , not applicable]

\begin{tabular}{|c|c|c|c|c|}
\hline Access field name & Excel field name & Field code & Field explanation & Field source \\
\hline LocM th & Location method & U & Unknown. & \\
\hline LOCACC & Location accuracy & -- & A ccuracy of latitude and longitude coordinates. & \\
\hline LOCACC & Location accuracy & $\mathrm{H}$ & H undredth second. & \\
\hline LOCACC & Location accuracy & 1 & Tenth second. & \\
\hline LOCACC & Location accuracy & 5 & Half second. & \\
\hline LOCACC & Location accuracy & $\mathrm{S}$ & Second. & \\
\hline LOCACC & Location accuracy & $\mathrm{R}$ & Three seconds. & \\
\hline LOCACC & Location accuracy & $\mathrm{F}$ & Five seconds. & \\
\hline LOCACC & Location accuracy & $\mathrm{T}$ & Ten seconds. & \\
\hline LOCACC & Location accuracy & M & M inute. & \\
\hline LOCACC & Location accuracy & U & Unknown. & \\
\hline DecL at83 & $\begin{array}{l}\text { Decimal latitude } \\
\text { NAD83 }\end{array}$ & - & $\begin{array}{l}\text { L atitude, in decimal degrees [automatically generated by the NWIS system software]; N orth } \\
\text { A merican Datum of } 1983 \text { (NAD 83). }\end{array}$ & \\
\hline DecLng83 & $\begin{array}{l}\text { Decimal longitude } \\
\text { NAD83 }\end{array}$ & - & $\begin{array}{l}\text { L ongitude, in decimal degrees [automatically generated by NWIS system software]; N orth A merican } \\
\text { Datum of } 1983 \text { (NAD 83). }\end{array}$ & \\
\hline UTME $27 m$ & $\begin{array}{l}\text { UTM Easting NAD } 27 \\
\text { (meters) }\end{array}$ & - & $\begin{array}{l}\text { U niversal Transverse M ercator coordinates, Easting, zone 11, in meters; N orth A merican Datum of } \\
1927 \text { (NA D 27). }\end{array}$ & \\
\hline UTMN27m & $\begin{array}{l}\text { UTM Northing } \\
\text { NAD27 (meters) }\end{array}$ & - & $\begin{array}{l}\text { U niversal Transverse M ercator coordinates, N orthing, zone 11, in meters; N orth A merican Datum of } \\
1927 \text { (NAD 27). }\end{array}$ & \\
\hline UTMErr & UTM error & - & UTM error, in meters. Blank if unknown. & \\
\hline Rmk & Remarks & - & Pertinent remarks pertaining to the lithologic description. & \\
\hline DtRcdL stUpd & $\begin{array}{l}\text { Date record last } \\
\text { updated }\end{array}$ & - & $\begin{array}{l}\text { Date of data entry (compiled into electronic format) is listed if a row of record has not been modified. } \\
\text { The date of last (most recent) update is listed if a row of record has been modified. This date does } \\
\text { not indicate which columns of data have been modified; only that records have been updated within } \\
\text { a particular row. Dates are listed as yyyymmdd (4-digit year; 2-digit month; 2-digit day). }\end{array}$ & \\
\hline URLAdr & URL address & - & L ink to online w ebsite and database. & \\
\hline
\end{tabular}


Digitally Available Interval-Specific Rock-Sample Data Compiled from Historical Records, Nevada Test Site, Nevada

This page left intentionally blank 


\section{Appendix C. Rock-Property Database, Nevada Test Site and Vicinity, Nye County, Nevada}

R ock-property data were compiled for both underground and surface sites located on and around the NTS. A ppendix C data are available at URL: http://pubs.usgs.gov/ ds/2007/2971.

Table C1. Description of Rock-Property Database field contents.

[A ccess field names longer than 8 characters indicated by red text because longer names may be incompatible with some database and Graphic Information System (GIS) applications. Blank field source indicates not applicable, not available online, or not accessible to the public. Abbreviations: DOD, U.S. Department of Defense; DOE, U.S. Department of Energy; NTS, N evada Test Site; NWIS, N ational Water Information System; USGS, U.S. Geological Survey; ft, foot; - , not applicable]

\begin{tabular}{|c|c|c|c|c|}
\hline Access field name & Excel field name & Field code & Field explanation & Field source \\
\hline SrtOrdUSGS & USGS NTS sort order & - & $\begin{array}{l}\text { E mplacement and exploratory holes typically are displayed together. M any sites also have multiple } \\
\text { completion intervals within the same hole. Therefore, a sort order number is assigned to all } \\
\text { USGS sites associated with DOE and/or DOD projects in N evada. This field is modified as new } \\
\text { sites are added. }\end{array}$ & \\
\hline UnqNoUSGS & $\begin{array}{l}\text { USGS NTS unique } \\
\text { number }\end{array}$ & - & $\begin{array}{l}\text { Spatial }(X-Y) \text { coordinates are unavailable at some locations. Therefore, USGS site identification } \\
\text { numbers cannot be established in the USGS NW IS database Sitefile for these sites. Because } \\
\text { NWIS site identification numbers cannot be assigned to all sites, it is necessary to assign a } \\
\text { unique site number to all USGS sites associated with USGS D OE/D OD projects in N evada. } \\
\text { A Ithough the unique numbers were initially assigned in the same order as the USGS NTS sort } \\
\text { order, new sites are assigned the next available sequential number. }\end{array}$ & \\
\hline NTSA rea & NTS area & - & $\begin{array}{l}\text { NTS A dministrative A rea number (see fig. 1). Entries are listed in bold type where sites are } \\
\text { located in areas other than the hole name implies. For example, USGS hole name } \mathbf{U}-\mathbf{4 t} \text { is } \\
\text { actually located in NTS area } \mathbf{0 7 .}\end{array}$ & \\
\hline HleN meUSGS & USGS hole name & - & $\begin{array}{l}\text { USGS hole name designation. Entries are listed in bold type where sites are located in areas other } \\
\text { than the hole name implies. }\end{array}$ & \\
\hline SmplntNo & Sample interval number & - & Sequence of sample interval. & \\
\hline SmplntSeq & $\begin{array}{l}\text { Sample sequence } \\
\text { number }\end{array}$ & - & Sequence of samples, when multiple analyses are reported within a sample interval. & \\
\hline SmplntTop & Sample interval top & - & $\begin{array}{l}\text { D epth to top of sample interval; below land surface for boreholes and shafts; from portal opening } \\
\text { for tunnels and drifts. }\end{array}$ & \\
\hline SmplntB tm & Sample interval bottom & - & $\begin{array}{l}\text { D epth to bottom of sample interval; below land surface for boreholes and shafts; from portal } \\
\text { opening for tunnels and drifts. }\end{array}$ & \\
\hline Unt01 & Units & - & Sample depth reporting units. & \\
\hline Date & Date & - & Date sample analyses reported (or analyzed; if known). & \\
\hline SpecGrav & Specific gravity & - & Specific gravity (sample density/water density). & \\
\hline GrnDen & Grain density & - & Grain density (dry weight/grain volume). & \\
\hline
\end{tabular}


Table C1. Description of Rock-Property Database field contents.-Continued

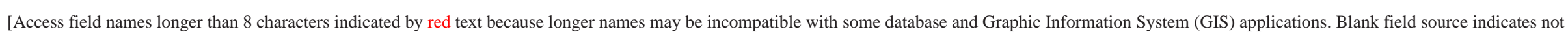

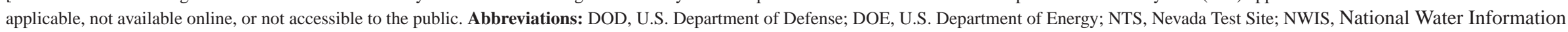
System; USGS, U.S. Geological Survey; ft, foot; -, not applicable]

\begin{tabular}{|c|c|c|c|c|}
\hline Access field name & Excel field name & Field code & Field explanation & Field source \\
\hline Unt02 & Units & - & Grain density reporting units. & \\
\hline DryBlkDen & Dry bulk density & - & Dry bulk density. Bulk density is defined as dry bulk density. & \\
\hline Unt03 & Units & - & Bulk density reporting units. & \\
\hline WetB IkD en & $\begin{array}{l}\text { Wet (natural-state) bulk } \\
\text { density }\end{array}$ & - & Wet bulk density. A Iso reported as natural- or sample-state bulk density. & \\
\hline Unt04 & Units & - & Bulk density reporting units. & \\
\hline WetH2OW tPer & $\begin{array}{l}\text { Wet } \mathrm{H}_{2} \mathrm{O} \text { content by } \\
\text { weight (percent) }\end{array}$ & - & $\begin{array}{l}\text { Wet } \mathrm{H}_{2} \mathrm{O} \text { content, by weight; as percentage. Computed as: [ } \% \mathrm{H}_{2} \mathrm{O} \text { volume / natural-state bulk } \\
\text { density]. }\end{array}$ & \\
\hline DryH2OW tPer & \begin{tabular}{|c}
$\begin{array}{c}\text { Dry } \mathrm{H}_{2} \mathrm{O} \text { content by } \\
\text { weight (percent) }\end{array}$ \\
\end{tabular} & - & D ry $\mathrm{H}_{2} \mathrm{O}$ content, by weight; as percentage. & \\
\hline H2OVolPer & $\begin{array}{l}\mathrm{H}_{2} \mathrm{O} \text { content by volume } \\
\text { (percent) }\end{array}$ & - & $\begin{array}{l}\mathrm{H}_{2} \mathrm{O} \text { content, by volume; as percentage. Computed as: [(natural-state bulk density - dry bulk } \\
\text { density) } * 100] .\end{array}$ & \\
\hline DryC02W tPer & \begin{tabular}{|c|}
$\begin{array}{c}\text { Dry } \mathrm{CO}_{2} \text { content by } \\
\text { weight (percent) }\end{array}$ \\
\end{tabular} & - & D ry $\mathrm{CO}_{2}$ content, by weight; as percentage. & \\
\hline PorosityPer & Porosity (percent) & - & Porosity; as percentage. & \\
\hline EffPorPer & $\begin{array}{c}\text { Effective porosity } \\
\text { (percent) }\end{array}$ & - & Effective porosity; as percentage. & \\
\hline Rmk01 & Remarks & - & $\begin{array}{l}\text { Remarks concerning sample analyses. Note: [the Copy } \mathbf{E} \mathbf{Q} \text { (hot) button contained in this column } \\
(\mathbf{X}) \text { automatically recomputes the following five values (blue-shaded columns } Y-Z, A A-A B \text {, } \\
\text { and } A D \text { ) for the entire rck_pty worksheet utilizing the equations contained in row } 2 \text { (the hidden } \\
\text { row)]. }\end{array}$ & \\
\hline CalcPorPer & $\begin{array}{l}\text { Computed porosity } \\
\text { (percent) }\end{array}$ & - & $\begin{array}{l}\text { Computed porosity; as percentage. Computed, using dry bulk density, as: [ }\{1 \text { - (dry bulk density / } \\
\text { grain density) }\} * 100] \text {. Computed, using natural-state bulk density, as: [ }\{1 \text { - ((natural-state bulk } \\
\text { density / grain density)* (1 - \% w et } \mathrm{H}_{2} \mathrm{O} \text { weight / 100))\}* 100]. Note: [Data generated in this } \\
\text { column represent raw, interval-specific, values that have not been corrected, averaged, or } \\
\text { weighted to a proposed working point and therefore may not agree with referenced data]. }\end{array}$ & \\
\hline CalcGasFilPorPer & $\begin{array}{r}\text { Computed gas-filled } \\
\text { porosity (percent) }\end{array}$ & - & $\begin{array}{l}\text { Computed gas-filled porosity; as percentage. Computed as: [porosity - (\% wet } \mathrm{H}_{2} \mathrm{O} \text { weight } * \\
\text { natural-state bulk density)]. Note: [Data generated in this column represent raw, interval- } \\
\text { specific, values that have not been corrected, averaged, or weighted to a proposed working } \\
\text { point and therefore may not agree with referenced data]. }\end{array}$ & \\
\hline CalcSatPer & $\begin{array}{l}\text { Computed saturation } \\
\text { (percent) }\end{array}$ & - & $\begin{array}{l}\text { Computed saturation; as percentage. Computed as: [ }\{(\% \text { wet } \mathrm{H} 20 \text { weight } * \text { natural-state bulk } \\
\text { density) / porosity }\} 100] \text {. Note: [Data generated in this column represent raw, interval- } \\
\text { specific, values that have not been corrected, averaged, or weighted to a proposed working } \\
\text { point and therefore may not agree with referenced data]. }\end{array}$ & \\
\hline
\end{tabular}


Table C1. Description of Rock-Property Database field contents.-Continued

[A ccess field names longer than 8 characters indicated by red text because longer names may be incompatible with some database and Graphic Information System (GIS) applications. Blank field source indicates not applicable, not available online, or not accessible to the public. Abbreviations: DOD, U.S. Department of Defense; DOE, U.S. Department of Energy; NTS, N evada Test Site; NWIS, N ational Water Information System; USGS, U.S. Geological Survey; ft, foot; - , not applicable]

\begin{tabular}{|c|c|c|c|c|}
\hline Access field name & Excel field name & Field code & Field explanation & Field source \\
\hline CalcD ryB IkDen & $\begin{array}{l}\text { Computed dry bulk } \\
\text { density }\end{array}$ & - & $\begin{array}{l}\text { Computed dry bulk density. Computed as: [natural-state bulk density * }\{1 \text { - (\% wet } \mathrm{H} 20 \text { weight / } \\
\text { 100)\}]. Note: [Data generated in this column represent raw, interval-specific, values that } \\
\text { have not been corrected, averaged, or weighted to a proposed working point and therefore } \\
\text { may not agree with referenced data]. }\end{array}$ & \\
\hline Unt05 & Units & - & Bulk density reporting units. & \\
\hline CalcSatB IkD en & $\begin{array}{l}\text { Computed saturated } \\
\text { bulk density }\end{array}$ & - & $\begin{array}{l}\text { Computed saturated bulk density. Computed, using analyzed dry bulk density, as: [analyzed dry } \\
\text { bulk density }+(\text { porosity / 100)]. Computed, computed dry bulk density, as: [computed dry bulk } \\
\text { density }+ \text { (porosity / 100)]. Note: [Data generated in this column represent raw, interval- } \\
\text { specific, values that have not been corrected, averaged, or weighted to a proposed working } \\
\text { point and therefore may not agree with referenced data]. }\end{array}$ & \\
\hline Unt06 & Units & - & Bulk density reporting units. & \\
\hline YoungsM od & Young's modulus & - & Young's modulus (or modulus of elasticity or tensile modulus). & \\
\hline BlkM od & Bulk modulus & - & Bulk modulus (or compression modulus). & \\
\hline ShrM od & Shear modulus & - & Shear modulus (or modulus of rigidity or 2nd Lame' constant). & \\
\hline ModUnt & Moduli units & - & M oduli reporting units. & \\
\hline PoissonsR at & Poisson's ratio & - & Poisson's ratio; a dimensionless value. & \\
\hline CmpVel & Compressional velocity & - & Compressional velocity (or longitudinal velocity; P waves). & \\
\hline ShrVel & Shear velocity & - & Shear velocity (or transverse velocity; S waves). & \\
\hline VelUnt & Velocity units & - & Velocity reporting units. & \\
\hline SmpPropst & Sample properties state & - & $\begin{array}{l}\text { M oduli (Young's, bulk, and shear) and velocity (compressional and shear) properties as well as } \\
\text { Poisson's ratio are reported for both static and dynamic states. M echanical rock property states } \\
\text { are: [D - dynamic; S - static; U (or blank) - undefined]. }\end{array}$ & \\
\hline Rmk02 & Remarks & - & Remarks concerning sample analyses. & \\
\hline UncCmpStr & $\begin{array}{l}\text { U nconfined } \\
\text { compressive strength }\end{array}$ & - & Unconfined compressive strength. & \\
\hline Unt07 & Units & - & Unconfined compressive strength reporting units. & \\
\hline SecY ngsM od & $\begin{array}{c}\text { Secant Young's } \\
\text { modulus }\end{array}$ & - & Secant Young's modulus. & \\
\hline Unt08 & Units & - & Secant Young's modulus reporting units. & \\
\hline SecRng & Secant range & - & Secant range. & \\
\hline Unt09 & Units & - & Secant range reporting units. & \\
\hline
\end{tabular}


Table C1. Description of Rock-Property Database field contents.-Continued

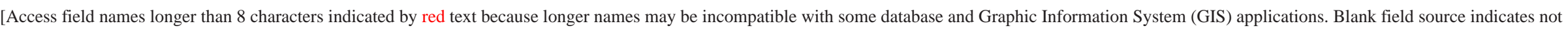

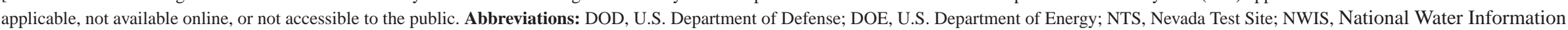
System; USGS, U.S. Geological Survey; ft, foot; -, not applicable]

\begin{tabular}{|c|c|c|c|c|}
\hline Access field name & Excel field name & Field code & Field explanation & Field source \\
\hline M agSusc & M agnetic susceptibility & - & M agnetic susceptibility. & \\
\hline Unt10 & Units & - & M agnetic susceptibility reporting units. & \\
\hline EndParCor & End parallelism of core & - & End parallelism of core. & \\
\hline Unt11 & Units & - & End parallelism of core reporting units. & \\
\hline ShrHrd & Shore hardness & - & Shore hardness. & \\
\hline Unt12 & Units & - & Shore hardness reporting units. & \\
\hline A nlyzA gy & A nalyzing agency & - & A gency that performed the sample analyses. & \\
\hline A nlyzA gy & A nalyzing agency & Birdwell & Birdwell Division of Seismograph Service Corporation (SSC). & \\
\hline A nlyzA gy & A nalyzing agency & BN & Bechtel Nevada (BN). & \\
\hline A nlyzAgy & A nalyzing agency & $\mathrm{CL}$ & Core Laboratories, Inc. (CL), B akersfield, California; Dallas, Texas. & \\
\hline A nlyzA gy & A nalyzing agency & DTRA & DOD, D efense Threat Reduction A gency (DTRA). & \\
\hline A nlyzA gy & A nalyzing agency & DRI & D esert Research Institute (DRI). & \\
\hline A nlyzA gy & A nalyzing agency & DS & Daniel B. Stephens and A ssociates, Inc. (DS), A lbuquerque, NM. & \\
\hline A nlyzA gy & A nalyzing agency & $F \& S$ & Fenix and Scisson, Inc. (F\&S). & \\
\hline A nlyzA gy & A nalyzing agency & FSN & Fenix and Scisson of N evada (FSN). & \\
\hline A nlyzAgy & A nalyzing agency & $H \& N$ & Holmes \& Narver, Inc. $(H \& N)$. & \\
\hline A nlyzA gy & A nalyzing agency & LANL & Los A lamos N ational L aboratory (LANL). & \\
\hline A nlyzA gy & A nalyzing agency & LLNL & Lawrence Livermore N ational L aboratory (LLNL). & \\
\hline A nlyzA gy & A nalyzing agency & NSTec & National Security Technologies, L LC (NSTec). & \\
\hline A nlyzAgy & A nalyzing agency & NTL & N evada Testing L aboratories, LTD. (NTL). & \\
\hline A nlyzA gy & A nalyzing agency & PTL & Pittsburgh Testing Laboratory (PTL), Salt Lake City, U tah. & \\
\hline A nlyzAgy & A nalyzing agency & REECO & Reynolds Electrical \& Engineering Company (REECo). & \\
\hline A nlyzA gy & A nalyzing agency & RSN & Raytheon Services N evada (RSN). & \\
\hline A nlyzAgy & A nalyzing agency & SNL & Sandia N ational L aboratories (SNL). & \\
\hline A nlyzA gy & A nalyzing agency & TT & $\begin{array}{l}\text { Terra Tek, Inc. (TT), Salt L ake City, U tah, a Schlumberger company; sometimes referred to as } \\
\text { TerraTek R esearch. }\end{array}$ & \\
\hline A nlyzA gy & A nalyzing agency & UI & U niversity of Illinois (UI). & \\
\hline A nlyzA gy & A nalyzing agency & USACE & U.S. A rmy Corps of Engineers (USACE). & \\
\hline A nlyzAgy & A nalyzing agency & USGS & USGS. & \\
\hline DatSrc & Data source & - & A gency that reported rock-property data. & \\
\hline DatSrc & Data source & Birdwell & Birdwell Division of Seismograph Service Corporation (SSC). & \\
\hline DatSrc & Data source & $\mathrm{BN}$ & Bechtel Nevada (BN). & \\
\hline
\end{tabular}


Table C1. Description of Rock-Property Database field contents.-Continued

[A ccess field names longer than 8 characters indicated by red text because longer names may be incompatible with some database and Graphic Information System (GIS) applications. Blank field source indicates not applicable, not available online, or not accessible to the public. Abbreviations: DOD, U.S. Department of Defense; DOE, U.S. Department of Energy; NTS, N evada Test Site; NWIS, N ational Water Information System; USGS, U.S. Geological Survey; ft, foot; -, not applicable]

\begin{tabular}{|c|c|c|c|c|}
\hline Access field name & Excel field name & Field code & Field explanation & Field source \\
\hline DatSrc & Data source & $C L$ & Core L aboratories, Inc. (CL), B akersfield, California; Dallas, Texas. & \\
\hline DatSrc & Data source & DTRA & DOD, D efense Threat R eduction A gency (DTRA). & \\
\hline DatSrc & Data source & DRI & Desert R esearch Institute (DRI). & \\
\hline DatSrc & Data source & DS & Daniel B. Stephens and A ssociates, Inc. (DS), A Ibuquerque, N M. & \\
\hline DatSrc & Data source & $F \& S$ & Fenix and Scisson, Inc. (F\&S). & \\
\hline DatSrc & Data source & FSN & Fenix and Scisson of N evada (FSN). & \\
\hline DatSrc & Data source & $H \& N$ & Holmes \& N arver, Inc. $(H \& N)$ & \\
\hline DatSrc & Data source & LANL & Los A lamos National Laboratory (LA NL). & \\
\hline DatSrc & Data source & LLNL & Law rence L ivermore N ational L aboratory (L L NL). & \\
\hline DatSrc & Data source & NSTec & N ational Security Technologies, LLC (NSTec). & \\
\hline DatSrc & Data source & NTL & N evada Testing L aboratories, LTD. (NTL). & \\
\hline DatSrc & Data source & PTL & Pittsburgh Testing L aboratory (PTL), Salt L ake City, U tah. & \\
\hline DatSrc & Data source & REECO & Reynolds Electrical \& Engineering Company (REECo). & \\
\hline DatSrc & Data source & RSN & R aytheon Services N evada (RSN). & \\
\hline DatSrc & Data source & SNL & Sandia National L aboratories (SNL). & \\
\hline DatSrc & Data source & TT & $\begin{array}{l}\text { Terra Tek, Inc. (TT), Salt Lake City, U tah, a Schlumberger company; sometimes referred to as } \\
\text { TerraTek R esearch. }\end{array}$ & \\
\hline DatSrc & Data source & UI & U niversity of Illinois (UI). & \\
\hline DatSrc & Data source & USACE & U.S. A rmy Corps of Engineers (USACE). & \\
\hline DatSrc & Data source & USGS & USGS. & \\
\hline RcdTypDsc & $\begin{array}{c}\text { Record type or } \\
\text { description }\end{array}$ & - & Record description and/or document type. & \\
\hline RcdTypDsc & $\begin{array}{c}\text { Record type or } \\
\text { description }\end{array}$ & $B N / P F$ & B echtel N evada (BN) Project Files (PF). & \\
\hline RcdTypDsc & $\begin{array}{c}\text { Record type or } \\
\text { description }\end{array}$ & DTRA/PF & DOD, D efense Threat R eduction A gency (DTRA) Project Files (PF). & \\
\hline RcdTypDsc & $\begin{array}{c}\text { Record type or } \\
\text { description }\end{array}$ & $\mathrm{DRI} / \mathrm{PF}$ & D esert R esearch Institute (DRI) Project Files (PF). & \\
\hline RcdTypDsc & $\begin{array}{c}\text { Record type or } \\
\text { description }\end{array}$ & $D S / L R$ & Daniel B. Stephens and A ssociates, Inc. (DS) L aboratory Report (L R). & \\
\hline RcdTypDsc & $\begin{array}{c}\text { Record type or } \\
\text { description }\end{array}$ & $F \& S / P F$ & Fenix and Scisson, Inc. (F\& S) Project Files (PF). & \\
\hline
\end{tabular}


Table C1. Description of Rock-Property Database field contents.-Continued

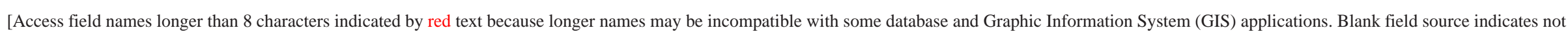

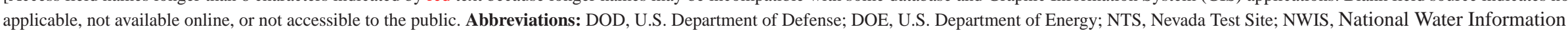
System; USGS, U.S. Geological Survey; ft, foot; -, not applicable]

\begin{tabular}{|c|c|c|c|c|}
\hline Access field name & Excel field name & Field code & Field explanation & Field source \\
\hline RcdTypDsc & $\begin{array}{c}\text { Record type or } \\
\text { description }\end{array}$ & FSN/PF & Fenix and Scisson of N evada (FSN) Project Files (PF). & \\
\hline RcdTypDsc & $\begin{array}{c}\text { Record type or } \\
\text { description }\end{array}$ & $H \& N / M T L$ & Holmes \& N arver, Inc. (H\&N) M aterials Testing Laboratory (M TL). & \\
\hline RcdTypDsc & $\begin{array}{c}\text { Record type or } \\
\text { description }\end{array}$ & LANL/PF & Los A lamos N ational L aboratory (LANL) Project Files (PF); referred to as "Blue Folders." & \\
\hline RcdTypDsc & $\begin{array}{c}\text { Record type or } \\
\text { description }\end{array}$ & LLNL/PF & L awrence Livermore N ational L aboratory (LLNL) Project Files (PF). & \\
\hline RcdTypDsc & $\begin{array}{c}\text { Record type or } \\
\text { description }\end{array}$ & NSTec/PF & N ational Security Technologies, LLC. (NSTec) Project Files (PF). & \\
\hline RcdTypDsc & $\begin{array}{c}\text { Record type or } \\
\text { description }\end{array}$ & REECo/ES & Reynolds Electrical \& Engineering Company (REECo) Environmental Sciences (ES). & \\
\hline RcdTypDsc & \begin{tabular}{|c|} 
Record type or \\
description
\end{tabular} & REECo/M L & Reynolds Electrical \& Engineering Company (REECo) M edical Laboratory (M L). & \\
\hline RcdTypDsc & $\begin{array}{c}\text { Record type or } \\
\text { description }\end{array}$ & REECo/PF & Reynolds Electrical \& Engineering Company (REECo) Project Files (PF). & \\
\hline RcdTypDsc & \begin{tabular}{|c|}
$\begin{array}{c}\text { Record type or } \\
\text { description }\end{array}$ \\
\end{tabular} & RSN/M TL & Raytheon Services N evada (RSN) M aterials Testing L aboratory (M TL). & \\
\hline RcdTypDsc & \begin{tabular}{|c|} 
Record type or \\
description
\end{tabular} & RSN/PF & Raytheon Services N evada (RSN) Project Files (PF). & \\
\hline RcdTypDsc & \begin{tabular}{|c|} 
Record type or \\
description
\end{tabular} & SNL/PF & Sandia N ational Laboratories (SNL) Project Files (PF). & \\
\hline RcdTypDsc & \begin{tabular}{|c|} 
Record type or \\
description
\end{tabular} & $\mathrm{UI} / \mathrm{TL}$ & U niversity of Illinois (UI) Talbot L aboratory (TL). & \\
\hline RcdTypDsc & $\begin{array}{c}\text { Record type or } \\
\text { description }\end{array}$ & USACE/WES & $\begin{array}{l}\text { U.S. A rmy Corps of Engineers (USACE) Waterways Experiment Station (W ES), Vicksburg, } \\
\text { M ississippi. }\end{array}$ & \\
\hline RcdTypDsc & \begin{tabular}{|c|} 
Record type or \\
description
\end{tabular} & $\begin{array}{l}\text { USGS/EGBL/ } \\
\quad \text { PPR }\end{array}$ & $\begin{array}{l}\text { U.S. Geological Survey (USGS) E ngineering G eology B ranch L aboratory (EGBL) Physical } \\
\text { Properties Results (PPR). }\end{array}$ & \\
\hline RcdTypDsc & $\begin{array}{c}\text { Record type or } \\
\text { description }\end{array}$ & USGS/PF & USGS Project Files (PF). & \\
\hline
\end{tabular}


Table C1. Description of Rock-Property Database field contents.-Continued

[A ccess field names longer than 8 characters indicated by red text because longer names may be incompatible with some database and Graphic Information System (GIS) applications. Blank field source indicates not applicable, not available online, or not accessible to the public. Abbreviations: DOD, U.S. Department of Defense; DOE, U.S. Department of Energy; NTS, Nevada Test Site; NWIS, N ational Water Information System; USGS, U.S. Geological Survey; ft, foot; - , not applicable]

\begin{tabular}{|c|c|c|c|c|}
\hline Access field name & Excel field name & Field code & Field explanation & Field source \\
\hline RptRef & Report reference & - & $\begin{array}{l}\text { Published report that contains rock-property data. A complete list of acronyms and abbreviations } \\
\text { used in U SGS and other reports is included in the usgs_rpt and nts_acr_abv worksheets in the } \\
\text { nts_rck_pty spreadsheet (appendix C). NOTE : [USG S Technical Letters are considered } \\
\text { internal correspondence and are not available for public release unless the report has been } \\
\text { assigned a USG S Open-File R eport number. Technical Letters prepared under the USG S } \\
\text { H ydrologic Resource M anagement Program (HR M P, formerly Hydrology/Radionuclide } \\
\text { M igration Program) and assigned "blanket open-file status" are designated "USG S- } \\
\text { 474-number." Technical Letters prepared under the USG S Yucca M ountain Program } \\
\text { (Y M P) and assigned "blanket open-file status" are designated "USG S-1543-number." } \\
\text { Furthermore, some reports prepared by the National L aboratories and the various } \\
\text { DOE and DO D subcontractors also may be considered internal correspondence and not } \\
\text { available for public release. Users interested in these reports must check with the source } \\
\text { agency to determine availability]. }\end{array}$ & \\
\hline Invst & Investigators & - & A uthors and/or investigators. & \\
\hline RecL OC & Record location & - & Physical location of rock-property record. & \\
\hline HleTyp & Hole type & - & Type of vertical or horizontal drilling or excavation. & \\
\hline HleTyp & Hole type & B orehole & Vertical surface location; includes wells and vertical test holes. & \\
\hline HleTyp & Hole type & Crater & Vertical surface location. & \\
\hline HleTyp & Hole type & Drift & H orizontal underground location; includes tunnels and horizontal test holes. & \\
\hline HleTyp & Hole type & M ultiple Wells & M ultiple wells. & \\
\hline HleTyp & Hole type & Outcrop & Surface location. & \\
\hline HleTyp & Hole type & Shaft & Vertical surface location. & \\
\hline HleTyp & Hole type & Spring & Spring. & \\
\hline HleTyp & Hole type & Streambed & Streambed. & \\
\hline HleTyp & Hole type & Surface & Surface location. & \\
\hline HleTyp & Hole type & Trench & Horizontal surface location. & \\
\hline HleTyp & Hole type & Unknown & Hole type not known. & \\
\hline TnlDftConSta & $\begin{array}{l}\text { Tunnel or drift } \\
\text { construction station }\end{array}$ & - & $\begin{array}{l}\text { Construction station at collar location (portal opening), for tunnels and drifts (i.e. - } 9+17 \text { is } 917 \mathrm{ft} \text {; } \\
10+72,195^{\prime} \text { is a } 195 \mathrm{ft} \text { hole at the } 1,072 \mathrm{ft} \text { station; etc.). }\end{array}$ & \\
\hline ConStaRmk & $\begin{array}{l}\text { Construction station } \\
\text { remarks }\end{array}$ & - & $\begin{array}{l}\text { Remarks concerning the portal opening (collar location), for tunnels and drifts (i.e. - In U -12e.14 } \\
\text { main drift; Alcove; Face; Invert; L ft Rib; Rt Rib; etc.). }\end{array}$ & \\
\hline NVSPE 27 & $\begin{array}{l}\text { N evada SPCS Easting } \\
\text { NAD } 27\end{array}$ & - & $\begin{array}{l}\text { N evada state plane coordinates (SPCS), Easting, central zone, in feet; N orth A merican Datum of } \\
1927 \text { (NA D 27). }\end{array}$ & \\
\hline NVSPN 27 & $\begin{array}{l}\text { N evada SPCS N orthing } \\
\text { NAD } 27\end{array}$ & - & $\begin{array}{l}\text { N evada state plane coordinates (SPCS), N orthing, central zone, in feet; N orth A merican Datum of } \\
1927 \text { (NA D 27). }\end{array}$ & \\
\hline
\end{tabular}


Table C1. Description of Rock-Property Database field contents.-Continued

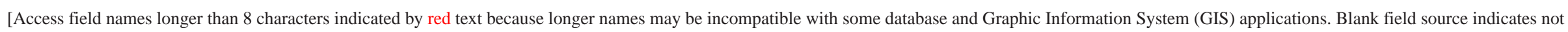

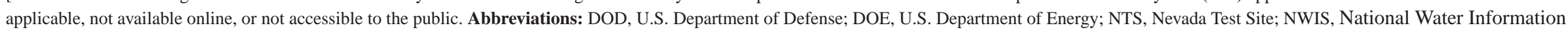
System; USGS, U.S. Geological Survey; ft, foot; -, not applicable]

\begin{tabular}{|c|c|c|c|c|}
\hline Access field name & Excel field name & Field code & Field explanation & Field source \\
\hline NVSPErr & SPCS error & -- & SPCS error, in feet. Blank if unknown. & \\
\hline AltPorOpn29ft & $\begin{array}{l}\text { A ltitude at portal } \\
\text { opening N GV D } 29 \\
\text { (ft) }\end{array}$ & - & $\begin{array}{l}\text { A ltitude at the collar location of the portal opening, for tunnels and drifts; in feet above mean sea } \\
\text { level; National G eodetic Vertical Datum of } 1929 \text { (N GV D29). }\end{array}$ & \\
\hline BngPorOpnDeg & $\begin{array}{l}\text { Bearing from portal } \\
\text { opening (degrees) }\end{array}$ & - & $\begin{array}{l}\text { B earing from the portal opening, for tunnels and drifts; in degrees, minutes, and seconds } \\
\text { or decimal degrees (i.e. - S0720958W is South, } 72 \text { degrees, } 9 \text { minutes, } 58 \text { seconds West; } \\
\text { N } 0325529 \mathrm{E} \text { is N orth, } 32 \text { degrees, } 55 \text { minutes, } 29 \text { seconds East; N 052.75W is N orth } 52 \text { and } \\
\text { three-quarter degrees West; etc.) }\end{array}$ & \\
\hline IncPorOpnD eg & $\begin{array}{l}\text { Inclination from portal } \\
\text { opening (degrees) }\end{array}$ & - & $\begin{array}{l}\text { Inclination from the portal opening, for tunnels and drifts; in degrees, minutes, and seconds or } \\
\text { decimal degrees (i.e. - } 0045825 \text { is a hole } 4 \text { degrees, } 58 \text { minutes, } 25 \text { seconds above horizontal; } \\
2700000 \text { is a vertical hole below horizontal; } 0900000 \text { is a vertical hole above horizontal; } \\
0000000 \text { and } 1800000 \text { are horizontal holes; } 0150000 \text { and } 1650000 \text { are holes } 15 \text { degrees up } \\
\text { (above horizontal); } 3150000 \text { and } 2250000 \text { are holes } 45 \text { degrees down (below horizontal); } 356.5 \\
\text { is a hole } 3 \text { and one-half degrees below horizontal; } 170.25 \text { is } 9 \text { and three-quarter degrees above } \\
\text { horizontal; etc.). Inclinations are linked to bearings, so values near horizontal for holes bearing } \\
\text { north or east would be added to zero for holes inclined above horizontal and subtracted from } \\
360 \text { for holes below horizontal; conversely, values near horizontal for holes bearing south or } \\
\text { west would be subtracted from } 180 \text { for holes inclined above horizontal and added to } 180 \text { for } \\
\text { holes below horizontal. }\end{array}$ & \\
\hline AltL ndSur29ft & $\begin{array}{l}\text { Altitude of land surface } \\
\text { NGVD29 (ft) }\end{array}$ & - & $\begin{array}{l}\text { A Ititude of land surface within a reasonable proximity of the site; in feet above mean sea level; } \\
\text { National G eodetic Vertical Datum of } 1929 \text { (N GV D 29). This is an average of the surrounding } \\
\text { ground-surface elevation. If the original surface has been altered, estimate the altitude based on } \\
\text { nearby unal tered terrain. }\end{array}$ & \\
\hline AltM th & Altitude method & - & M ethod used to determine altitude of land surface. & \\
\hline AltM th & Altitude method & $\mathrm{A}$ & A ltimeter. & \\
\hline AltM th & Altitude method & $\mathrm{D}$ & Differentially-corrected G lobal Positioning System (D GPS). & \\
\hline AltM th & Altitude method & G & Global Positioning System (GPS). & \\
\hline AltM th & Altitude method & 1 & Interferometric Synthetic A perture R adar (IfSA R), airplane. & \\
\hline AltM th & Altitude method & J & Light Detection A nd Ranging (LiDA R), airplane. & \\
\hline A ItM th & Altitude method & $\mathrm{L}$ & Level or other surveying method. & \\
\hline AltM th & Altitude method & M & $\begin{array}{l}\text { Interpolated from topographic map [report accuracy as } \pm \text { one-half the contour interval (or } \\
\text { supplementary contour interval) specified on the quadrangle]. }\end{array}$ & \\
\hline AltM th & Altitude method & $\mathrm{N}$ & Interpolated from digital el evation model (DEM). & \\
\hline A ltM th & Altitude method & $\mathrm{R}$ & Reported. & \\
\hline AltM th & Altitude method & U & Unknown. & \\
\hline
\end{tabular}


Table C1. Description of Rock-Property Database field contents.-Continued

[Access field names longer than 8 characters indicated by red text because longer names may be incompatible with some database and Graphic Information System (GIS) applications. B lank field source indicates not applicable, not available online, or not accessible to the public. Abbreviations: DOD, U.S. Department of Defense; DOE, U.S. Department of Energy; NTS, N evada Test Site; NWIS, N ational Water Information System; USGS, U.S. Geological Survey; ft, foot; - , not applicable]

\begin{tabular}{|c|c|c|c|c|}
\hline Access field name & Excel field name & Field code & Field explanation & Field source \\
\hline A ItA AcC & A ltitude accuracy & - & A ltitude accuracy; in feet (decimal values for accuracies less than $1 \mathrm{ft}$ ). & \\
\hline AltA CC & A ltitude accuracy & U & Unknown. & \\
\hline SitCmpDt & Site completion date & - & Date hole construction completed. & \\
\hline HleD thft & Hole depth (ft) & - & $\begin{array}{l}\text { Hole depth; in feet below land surface for boreholes and shafts; in feet from portal opening for } \\
\text { tunnels and drifts. }\end{array}$ & \\
\hline RedB kHleNo & Redbook hole number & - & $\begin{array}{l}\text { Redbook hole numbers are currently assigned to new holes completed at the NTS by N ational } \\
\text { Security Technologies, LLC (NSTec). Entries are listed in bold type where sites are located in } \\
\text { areas other than the hole name implies. }\end{array}$ & \\
\hline RedBkHleNo & Redbook hole number & - & $\begin{array}{l}\text { Redbook hole numbers listed in the Raytheon Services Nevada (RSN) N evada Test Site D rilling } \\
\text { and M ining Summary (last updated 12-31-90) and previously in the Fenix and Scisson of } \\
\text { N evada NTS Drilling and M ining Summary (last updated 06-30-89; formerly Fenix and Scisson, } \\
\text { Inc.) were assigned according to the type of hole drilled or mined, site location (NTS area), and } \\
\text { sequence code for the consecutive order in which the hole was drilled, mined, or recompleted. } \\
\text { Emplacement holes for nuclear weapons tests begin with the letter U, followed by a dash (-), } \\
\text { NTS area number (fig. 1), and sequence code (letters a-Z, aa-az, ba-bz, ..., za-zz). Exploratory } \\
\text { holes follow the same naming convention as emplacement holes, but begin with the letters } \\
\text { UE. H oles that begin with the letter U but were drilled or mined specifically to provide data } \\
\text { that could not be collected from an emplacement hole follow the emplacement hole naming } \\
\text { convention, but are assigned incremental letters or numbers, or both following the sequence } \\
\text { code. The suffix letters indicate: [\#, satellite hole; CH, cable hole; Ex. or Expl., exploratory } \\
\text { hole; HTH, hydrologic test hole; Inst., instrument hole; ITS, integrated test system; PPS, pre- } \\
\text { postshot hole; PS, post-shot hole; RN M , radionuclide migration hole; RW M S, radioactive waste } \\
\text { management site; and S, substitute hole]. There are numerous exceptions to the standard naming } \\
\text { convention. The prefix letters indicate: [H TH, hydrologic test hole; J, J ackass Flat; and R RM, } \\
\text { radionuclide migration]. Numbers and letters following the dash in the exceptions represent } \\
\text { sequence of site drilling or mining, not NTS location. Hole type also is commonly listed after } \\
\text { the hole designation. For example: [A ccess Shaft; Cable Hole; Expl. Hole; Instrument; L OS } \\
\text { (Line Of Sight) Drift; Sidetrack; R Reentry M ining; Tunnel; Vent Hole; and Zero Station]. }\end{array}$ & \\
\hline RedBkHleNo & Redbook hole number & - & $\begin{array}{l}\text { USGS D OE project-related holes in Central N evada follow a similar naming convention. However } \\
\text { emplacement holes begin with the letters UC and exploratory holes begin with the letters U CE. }\end{array}$ & \\
\hline RedB kHleNo & Redbook hole number & - & $\begin{array}{l}\text { U SGS Y ucca M ountain Project (Y M P) holes at the NTS follow the exploratory hole naming } \\
\text { convention. Offsite Y M P holes begin with the letters USW to indicate underground southern } \\
\text { N evada waste. The suffix letters indicate: [G, geologic hole; GA, geologic angle hole; GU, } \\
\text { geologic unsaturated zone hole; H, hydrologic hole; M X, missile-experimental hole (drilled for } \\
\text { U.S. Air Force [USA F ] M X M issile-Siting Investigation); N, neutron hole; p, Paleozoic or pre- } \\
\text { Tertiary hole; RF, repository facility hole; UZ, unsaturated zone hole; V, vol canic hole; VSE, } \\
\text { vertical shelter exploratory hole (drilled for USA F M X M issile-Siting Investigation); and WT } \\
\text { water table hole]. }\end{array}$ & \\
\hline
\end{tabular}


Table C1. Description of Rock-Property Database field contents.-Continued

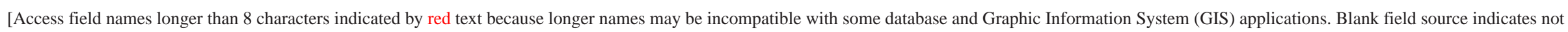

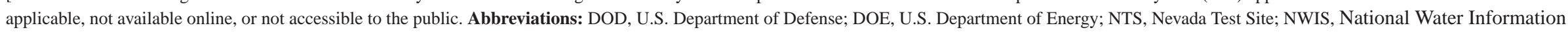
System; USGS, U.S. Geological Survey; ft, foot; -, not applicable]

\begin{tabular}{|c|c|c|c|c|}
\hline Access field name & Excel field name & Field code & Field explanation & Field source \\
\hline RedB kHleNo & Redbook hole number & - & $\begin{array}{l}\text { Environmental Restoration Program (ERP) holes at the NTS begin with the letters ER, follow ed by } \\
\text { a dash, NTS area number (fig. 1), a dash, and an incremental sequence number. The NTS area } \\
\text { number is replaced by suffix letters for ERP holes located offsite. The suffix letters indicate: } \\
\text { [EC, area at the USAF N ellis A ir Force B ase Range (NAFBR) where the holes were drilled; and } \\
\text { OV, Oasis Valley]. }\end{array}$ & \\
\hline RedB kHleNo & Redbook hole number & - & 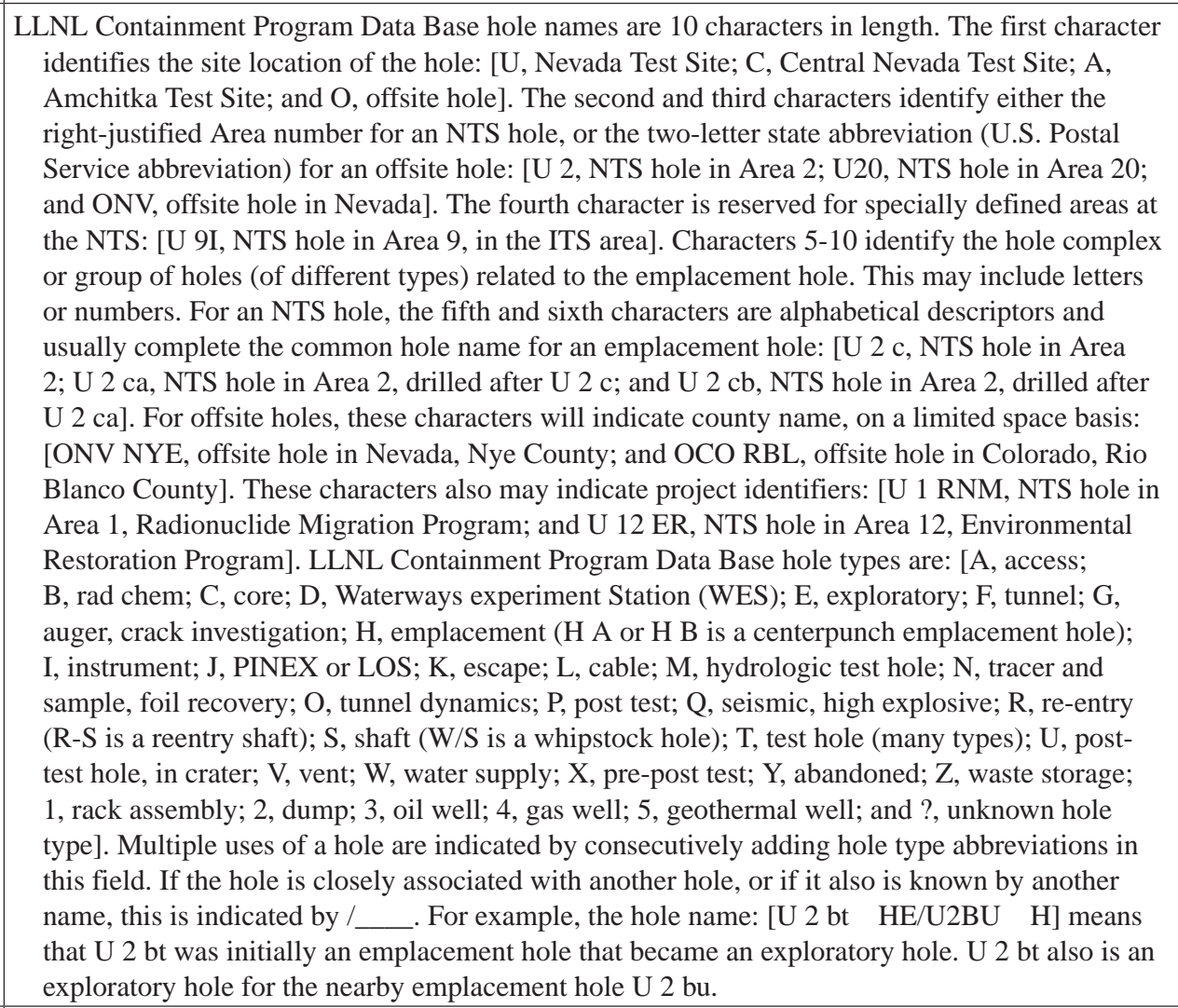 & \\
\hline FmrOthHleN me & $\begin{array}{l}\text { Former or other hole } \\
\text { name }\end{array}$ & - & Former or other names utilized for holes. & \\
\hline A gyCdUSGSNWIS & NW IS agency code & USGS & $\begin{array}{l}\text { USGS N WIS code to indicate the reporting agency. A II sites currently populated in the rock- } \\
\text { property database are assigned as USGS. }\end{array}$ & \\
\hline
\end{tabular}


Table C1. Description of Rock-Property Database field contents.-Continued

[A ccess field names longer than 8 characters indicated by red text because longer names may be incompatible with some database and Graphic Information System (GIS) applications. Blank field source indicates not applicable, not available online, or not accessible to the public. Abbreviations: DOD, U.S. Department of Defense; DOE, U.S. Department of Energy; NTS, N evada Test Site; NWIS, N ational Water Information System; USGS, U.S. Geological Survey; ft, foot; - , not applicable]

\begin{tabular}{|c|c|c|c|c|}
\hline Access field name & Excel field name & Field code & Field explanation & Field source \\
\hline SitID NoUSGSNWIS & $\begin{array}{l}\text { N WIS site } \\
\text { identification number }\end{array}$ & - & USGS NWIS site identification number. & \\
\hline SitID NoUSGSNWIS & $\begin{array}{l}\text { NWIS site } \\
\text { identification number }\end{array}$ & - & $\begin{array}{l}\text { D ownstream order numbers are assigned for surface-water, on-stream, sites. The first two digits } \\
\text { of the station number indicate the part or major drainage system formerly used for USGS } \\
\text { Water-Supply Papers entitled "Surface Water Supply of the U nited States" and the remaining } \\
\text { digits indicate the downstream order within the part. This site number is left-justified. Although } \\
\text { downstream identification numbers have been converted to a variable length format, with up to } \\
14 \text { digits available, } 8 \text { digits are normally assigned. }\end{array}$ & \\
\hline SitIDNoUSGSNWIS & $\begin{array}{l}\text { NWIS site } \\
\text { identification number }\end{array}$ & - & $\begin{array}{l}\text { Numbering system for sites on open water bodies, off-channel sites, wells, springs, etc., is based } \\
\text { on the grid system of latitude and longitude. A lthough this number is initially determined from } \\
\text { the best known latitude/longitude location, plus a 2-digit sequence number for the number of } \\
\text { sites located at those coordinates, it retains no locational relevance once the site is created in the } \\
\text { database. The overall designation consists of } 15 \text { digits. The values of latitude and longitude are } \\
\text { updated as better coordinates become available, and should always be used for locating sites or } \\
\text { plotting locations. }\end{array}$ & \\
\hline Lat27 & Latitude NA D 27 & - & $\begin{array}{l}\text { Latitude; in degrees, minutes, and seconds [two digits are available for decimal seconds]; North } \\
\text { A merican Datum of } 1927 \text { (NA D27). }\end{array}$ & \\
\hline Lng27 & Longitude NA D27 & - & $\begin{array}{l}\text { Longitude; in degrees, minutes, and seconds [two digits are available for decimal seconds]; N orth } \\
\text { A merican Datum of } 1927 \text { (NA D27). }\end{array}$ & \\
\hline LocM th & Location method & - & M ethod used to determine latitude and longitude coordinates. & \\
\hline LocM th & Location method & C & Calculated from land net. & \\
\hline LocM th & Location method & D & Differentially-corrected Global Positioning System (DGPS). & \\
\hline LocM th & L ocation method & G & $\begin{array}{l}\text { G lobal positioning system (GPS), uncorrected [Standard Positioning Service (SPS) and Precise } \\
\text { Positioning Service (PPS)]. }\end{array}$ & \\
\hline LocM th & Location method & L & L ong-range navigation (L oran) system. & \\
\hline LocM th & Location method & M & Interpolated from map. & \\
\hline LocM th & Location method & $\mathrm{N}$ & Interpolated from digital map. & \\
\hline LocM th & Location method & $\mathrm{R}$ & Reported. & \\
\hline LocM th & Location method & $\mathrm{S}$ & Transit, theodolite, or other surveying method. & \\
\hline LocM th & Location method & $\mathrm{U}$ & Unknown. & \\
\hline LOCACC & Location accuracy & - & A ccuracy of latitude and longitude coordinates. & \\
\hline LOCACC & Location accuracy & $\mathrm{H}$ & H undredth second. & \\
\hline LOCACC & Location accuracy & 1 & Tenth second. & \\
\hline LOCACC & Location accuracy & 5 & Half second. & \\
\hline
\end{tabular}


Table C1. Description of Rock-Property Database field contents.-Continued

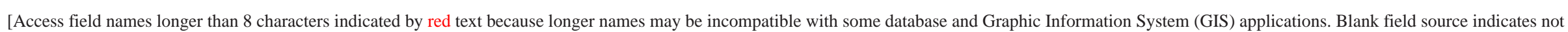

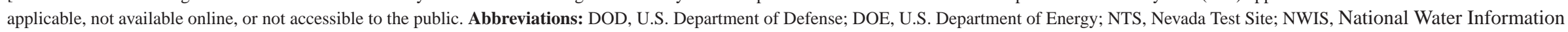
System; USGS, U.S. Geological Survey; ft, foot; -, not applicable]

\begin{tabular}{|c|c|c|c|c|}
\hline Access field name & Excel field name & Field code & Field explanation & Field source \\
\hline LoCA CC & Location accuracy & $\mathrm{S}$ & Second. & \\
\hline LoCACC & Location accuracy & $\mathrm{R}$ & Three seconds. & \\
\hline LOCACC & Location accuracy & $\mathrm{F}$ & Five seconds. & \\
\hline LOCACC & Location accuracy & $\mathrm{T}$ & Ten seconds. & \\
\hline LOCACC & Location accuracy & M & M inute. & \\
\hline LOCACC & Location accuracy & $\mathrm{U}$ & Unknown. & \\
\hline DecL at83 & $\begin{array}{l}\text { Decimal latitude } \\
\text { NAD83 }\end{array}$ & - & $\begin{array}{l}\text { Latitude, in decimal degrees [automatically generated by the N WIS system software]; North } \\
\text { A merican Datum of } 1983 \text { (NA D 83). }\end{array}$ & \\
\hline DecL ng83 & $\begin{array}{l}\text { Decimal longitude } \\
\text { NAD83 }\end{array}$ & - & $\begin{array}{l}\text { Longitude, in decimal degrees [automatically generated by NW IS system software]; N orth } \\
\text { A merican Datum of } 1983 \text { (NA D 83). }\end{array}$ & \\
\hline UTME27m & $\begin{array}{l}\text { UTM Easting NAD } 27 \\
\text { (meters) }\end{array}$ & - & $\begin{array}{l}\text { U niversal Transverse M ercator coordinates, Easting, zone 11, in meters; N orth A merican Datum of } \\
1927 \text { (NA D 27). }\end{array}$ & \\
\hline UTM N27m & $\begin{array}{l}\text { UTM Northing NAD } 27 \\
\text { (meters) }\end{array}$ & - & $\begin{array}{l}\text { U niversal Transverse M ercator coordinates, Northing, zone 11, in meters; N orth A merican Datum } \\
\text { of } 1927 \text { (NAD 27). }\end{array}$ & \\
\hline UTMErr & UTM error & - & UTM error, in meters. Blank if unknown. & \\
\hline Rmk03 & Remarks & - & Pertinent remarks pertaining to the rock properties. & \\
\hline DtRcdL stUpd & $\begin{array}{l}\text { Date record last } \\
\quad \text { updated }\end{array}$ & - & $\begin{array}{l}\text { Date of data entry (compiled into electronic format) is listed if a row of record has not been } \\
\text { modified. The date of last (most recent) update is listed if a row of record has been modified. } \\
\text { This date does not indicate which columns of data have been modified; only that records have } \\
\text { been updated within a particular row. D ates are listed as yyyymmdd (4-digit year; 2-digit month; } \\
\text { 2-digit day). }\end{array}$ & \\
\hline URLAdr & URL address & - & Link to online website and database. & \\
\hline
\end{tabular}




\section{Appendix D. Fracture-Characteristic Database, Nevada Test Site and Vicinity, Nye County, Nevada.}

Fracture-characteristic data were compiled for both underground and surface sites located on and around the NTS. A ppendix D data are available at URL: $\underline{\text { http://pubs. }}$ usgs.gov/ds/2007/297/.

Table D1. Description of Fracture-Characteristic Database field contents.

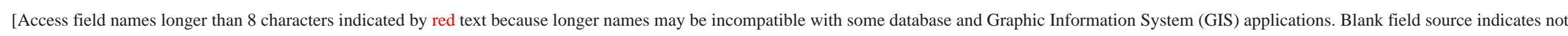

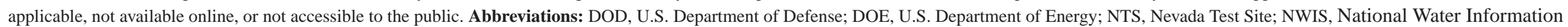
System; USGS, U.S. Geological Survey; ft, foot; -, not applicable]

\begin{tabular}{|c|c|c|c|c|}
\hline Access field name & Excel field name & Field code & Field explanation & Field source \\
\hline SrtOrdUSGS & USGS NTS sort order & - & $\begin{array}{l}\text { E mplacement and exploratory holes typically are displayed together. M any sites also have multiple } \\
\text { completion intervals within the same hole. Therefore, a sort order number is assigned to all } \\
\text { USGS sites associated with DOE and/or D OD projects in Nevada. This field is modified as new } \\
\text { sites are added. }\end{array}$ & \\
\hline UnqNoUSGS & $\begin{array}{l}\text { USGS NTS unique } \\
\text { number }\end{array}$ & - & $\begin{array}{l}\text { Spatial }(X-Y) \text { coordinates are unavailable at some locations. Therefore, USGS site identification } \\
\text { numbers cannot be established in the USGS NWIS database Sitefile for these sites. B ecause } \\
\text { NW IS site identification numbers cannot be assigned to all sites, it is necessary to assign a } \\
\text { unique site number to all USGS sites associated with USGS DOE/DOD projects in N evada. } \\
\text { A Ithough the unique numbers were initially assigned in the same order as the USGS NTS sort } \\
\text { order, new sites are assigned the next available sequential number. }\end{array}$ & \\
\hline NTSA rea & NTS area & - & $\begin{array}{l}\text { NTS A dministrative A rea number (see fig. 1). Entries are listed in bold type where sites are } \\
\text { located in areas other than the hole name implies. For example, USGS hole name UE-14b is } \\
\text { actually located in NTS area } \mathbf{0 6 .}\end{array}$ & \\
\hline HleNmeUSGS & USGS hole name & - & $\begin{array}{l}\text { USGS hole name designation. Entries are listed in bold type where sites are located in areas other } \\
\text { than the hole name implies. }\end{array}$ & \\
\hline FctlntNo & $\begin{array}{l}\text { Fracture interval } \\
\text { number }\end{array}$ & - & Sequence of fracture interval. & \\
\hline FctlntSeq & $\begin{array}{l}\text { Fracture interval } \\
\text { sequence number }\end{array}$ & - & Sequence of descriptions, when multiple descriptions are reported within a fracture interval. & \\
\hline FctlntTopft & $\begin{array}{l}\text { Fracture interval top } \\
(\mathrm{ft})\end{array}$ & - & $\begin{array}{l}\text { Top of fracture interval; in feet below land surface for boreholes and shafts; in feet from portal } \\
\text { opening for tunnels and drifts. }\end{array}$ & \\
\hline Fctl ntB tmft & $\begin{array}{l}\text { Fracture interval } \\
\text { bottom (ft) }\end{array}$ & - & $\begin{array}{l}\text { Bottom of fracture interval; in feet below land surface for boreholes and shafts; in feet from portal } \\
\text { opening for tunnels and drifts. }\end{array}$ & \\
\hline FctDsc & Fracture description & - & Description of fracture characteristics. & \\
\hline FctF reqft & $\begin{array}{l}\text { Fracture frequency } \\
\text { (fractures/ft) }\end{array}$ & - & Frequency of fractures; as fractures per foot. & \\
\hline
\end{tabular}


Table D1. Description of Fracture-Characteristic Database field contents.-Continued

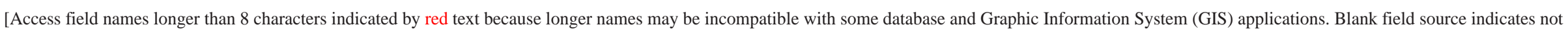

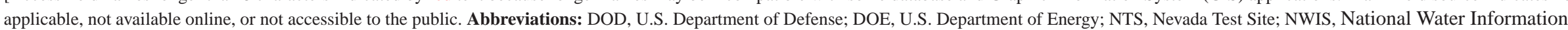
System; USGS, U.S. Geological Survey; ft, foot; -, not applicable]

\begin{tabular}{|c|c|c|c|c|}
\hline Access field name & Excel field name & Field code & Field explanation & Field source \\
\hline FctO rientD eg & $\begin{array}{l}\text { Fracture orientation } \\
\text { (degrees) }\end{array}$ & - & Orientation of fractures; as degrees from horizontal to vertical. & \\
\hline FctRmk & Fracture remarks & - & Pertinent comments concerning fracture descriptions. & \\
\hline L thlntNo & $\begin{array}{l}\text { Lithologic interval } \\
\text { number }\end{array}$ & - & Sequence of lithologic interval adjacent to fracture interval. & \\
\hline L thlntSeq & $\begin{array}{l}\text { Lithologic interval } \\
\text { sequence number }\end{array}$ & - & Sequence of descriptions, when multiple descriptions are reported within a lithologic interval. & \\
\hline L thlntTopft & $\begin{array}{l}\text { Lithologic interval top } \\
\text { (ft) }\end{array}$ & - & $\begin{array}{l}\text { Top of lithologic unit adjacent to fracture interval; in feet bel ow land surface for boreholes and } \\
\text { shafts; in feet from portal opening for tunnels and drifts. }\end{array}$ & \\
\hline L thlntB tmft & $\begin{array}{l}\text { Lithologic interval } \\
\text { bottom (ft) }\end{array}$ & - & $\begin{array}{l}\text { B ottom of lithologic unit adjacent to fracture interval; in feet below land surface for boreholes and } \\
\text { shafts; in feet from portal opening for tunnels and drifts. }\end{array}$ & \\
\hline SmpL ogTyp & Sample or log type & - & Type of sample or log that lithologic description is based upon. & \\
\hline SmpL ogTyp & Sample or log type & Basket & - & \\
\hline SmpL ogTyp & Sample or log type & $\begin{array}{l}\text { Binocular } \\
\text { microscope }\end{array}$ & - & \\
\hline SmpL ogTyp & Sample or log type & Bit & - & \\
\hline SmpL ogTyp & Sample or log type & Core & - & \\
\hline SmpL ogTyp & Sample or log type & $\begin{array}{c}\text { Core and } \\
\text { Cuttings }\end{array}$ & - & \\
\hline SmpL ogTyp & Sample or log type & $\begin{array}{l}\text { Core and } \\
\text { Geophysical } \\
\log \end{array}$ & - & \\
\hline SmpL ogTyp & Sample or log type & $\begin{array}{l}\text { Core and } \\
\text { M ovie log }\end{array}$ & - & \\
\hline SmpL ogTyp & Sample or log type & $\begin{array}{l}\text { Core and } \\
\text { Sidewall }\end{array}$ & - & \\
\hline SmpL ogTyp & Sample or log type & $\begin{array}{r}\text { Core, Sidewall, } \\
\text { and Cuttings }\end{array}$ & - & \\
\hline SmpL ogTyp & Sample or log type & Cuttings & - & \\
\hline SmpL ogTyp & Sample or log type & \begin{tabular}{|l|}
$\begin{array}{l}\text { Cuttings and } \\
\text { Geophysical } \\
\log \end{array}$ \\
\end{tabular} & - & \\
\hline SmpL ogTyp & Sample or log type & $\begin{array}{l}\text { Cuttings and } \\
\text { M ovie log }\end{array}$ & - & \\
\hline
\end{tabular}


Table D1. Description of Fracture-Characteristic Database field contents.-Continued

[A ccess field names longer than 8 characters indicated by red text because longer names may be incompatible with some database and Graphic Information System (GIS) applications. Blank field source indicates not applicable, not available online, or not accessible to the public. Abbreviations: DOD, U.S. Department of Defense; DOE, U.S. Department of Energy; NTS, Nevada Test Site; NWIS, National Water Information System; USGS, U.S. Geological Survey; ft, foot; -, not applicable]

\begin{tabular}{|c|c|c|c|c|}
\hline Access field name & Excel field name & Field code & Field explanation & Field source \\
\hline SmpL ogTyp & Sample or log type & Field notes & - & \\
\hline SmpL ogTyp & Sample or log type & $\begin{array}{l}\text { Geophysical } \\
\log \end{array}$ & - & \\
\hline SmpL ogTyp & Sample or log type & Grab & - & \\
\hline SmpL ogTyp & Sample or log type & M ovie log & - & \\
\hline SmpL ogTyp & Sample or log type & None & - & \\
\hline SmpL ogTyp & Sample or log type & Sidewall & - & \\
\hline SmpL ogTyp & Sample or log type & $\begin{array}{c}\text { Sidewall and } \\
\text { Cuttings }\end{array}$ & - & \\
\hline SmpL ogTyp & Sample or log type & $\begin{array}{l}\text { Sidewall and } \\
\text { Geophysical } \\
\text { log }\end{array}$ & - & \\
\hline SmpL ogTyp & Sample or log type & $\begin{array}{r}\text { Sidewall and } \\
\text { M ovie log }\end{array}$ & - & \\
\hline SmpL ogTyp & Sample or log type & Thin section & - & \\
\hline SmpL ogTyp & Sample or log type & Unknown & - & \\
\hline LthDsc & Lithologic description & - & $\begin{array}{l}\text { Entire lithologic description verbatim. The intent is to offer the most comprehensive (usually the } \\
\text { original) description available. Core and sidewall samples always take precedence over cuttings } \\
\text { descriptions. M ultiple descriptions exist for many holes. However, subsequent descriptions are } \\
\text { abridged and important alteration and structural inferences are lost. Although stratigraphic units } \\
\text { are frequently updated and lithologies are occasionally modified, original descriptions still take } \\
\text { precedence because cuttings samples were interpreted with the aid of binocular microscopes } \\
\text { and questionable core samples were interpreted from thin sections utilizing petrographic } \\
\text { microscopes (and occasionally spectrographic analysis). }\end{array}$ & \\
\hline GeoUntUSGSNWIS & $\begin{array}{l}\text { USGS NW IS geologic } \\
\text { unit }\end{array}$ & - & $\begin{array}{l}\text { Geologic unit or aquifer name code stored in the Ground-Water Information System (GWSI) } \\
\text { subsystem of the USGS N W IS Ingress database. For example: [110V LFL - Q Quaternary valley } \\
\text { fill; 121A M TK - Tertiary A mmonia Tanks M ember; 121R R M S - Tertiary Rainier M esa } \\
\text { M ember; 122PB RS - Tertiary Paintbrush Tuff; 327ELEN - Pennsylvanian Eleana Formation; } \\
\text { 331CN M N - M ississippian Chainman Shale; 344NEVD - D evonian Nevada Formation; } \\
\text { 361EURK - Ordovician Eureka Quartzite; and 400SRLG - Precambrian Stirling Quartzite]. A } \\
\text { complete list of codes is included in the nv_geo_unt worksheet in the nts_fct_chr spreadsheet } \\
\text { (appendix D). }\end{array}$ & \\
\hline LthUntUSGSN WIS & $\begin{array}{l}\text { USGS NWIS lithologic } \\
\text { unit }\end{array}$ & - & $\begin{array}{l}\text { Lithologic unit code stored in the GWSI database. For example: [A LVM - alluvium; CLAY - clay; } \\
\text { DLM M - dolomite; GRVL - gravel; LM SN - limestone; QRTZ - quartzite; SA ND - sand; SHLE } \\
\text { - shale; and TUFF - tuff]. A complete list of codes is included in the lith_unt worksheet in the } \\
\text { nts_fct_chr spreadsheet (appendix D). }\end{array}$ & \\
\hline
\end{tabular}


Table D1. Description of Fracture-Characteristic Database field contents.-Continued

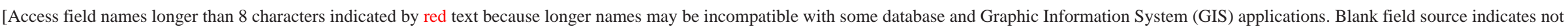

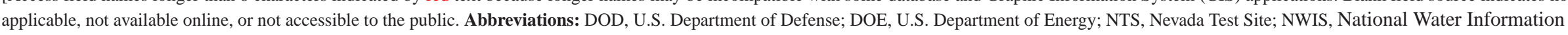
System; USGS, U.S. Geological Survey; ft, foot; -, not applicable]

\begin{tabular}{|c|c|c|c|c|}
\hline Access field name & Excel field name & Field code & Field explanation & Field source \\
\hline M apUntSym & M ap unit symbol & - & $\begin{array}{l}\text { A list of map unit symbols commonly used at the NTS and vicinity are provided. For example: } \\
\text { [QTa - middle Pleistocene to late Tertiary alluvial deposits; Tac - M iocene Calico Hills } \\
\text { Formation; Tbgr - Tertiary crystal-rich Grouse Canyon Tuff; Tcpk - Tertiary Rhyolite of } \\
\text { Kearsarge; TnABCD - Tertiary Tunnel Formation, } 4 \mathrm{M} \text { ember, beds 4A, 4B, 4C, and 4D; Oaa } \\
\text { - Ordovician A ntelope Valley Limestone, Aysees Peak M ember; and Dg - upper and middle } \\
\text { Devonian Guilmette Formation]. A complete list of codes is included in the map_unt worksheet } \\
\text { in the nts fct chr spreadsheet (appendix D). }\end{array}$ & \\
\hline LthR mk & Lithologic remarks & - & $\begin{array}{l}\text { Comments pertaining to lithologic-interval descriptions. Currently used mostly to house } \\
\text { stratigraphic/lithologic references included with written descriptions; these data are utilized as } \\
\text { an aid for populating the USGS NWIS geologic unit and USGS N WIS lithologic unit columns. }\end{array}$ & \\
\hline DatSrc & Data source & - & A gency that reported fracture-characteristic data. & \\
\hline DatSrc & Data source & AML & A nalytical M aterials L aboratory, 3463 State Street, \#349, Santa B arbara, California. & \\
\hline DatSrc & Data source & BN & Bechtel N evada (BN). & \\
\hline DatSrc & Data source & DTRA & DOD, D efense Threat R eduction A gency (DTRA). & \\
\hline DatSrc & Data source & $F \& S$ & Fenix and Scisson, Inc. (F\&S). & \\
\hline DatSrc & Data source & FSN & Fenix and Scisson of N evada (FSN). & \\
\hline DatSrc & Data source & IT Corp. & International Technology Corporation (IT Corp., purchased by Shaw Group, Inc.). & \\
\hline DatSrc & Data source & LANL & Los A lamos National Laboratory (LA NL). & \\
\hline DatSrc & Data source & LLNL & L aw rence L ivermore National Laboratory (LL NL). & \\
\hline DatSrc & Data source & NDWR & $\begin{array}{l}\text { State of N evada, Department of Conservation and } \mathrm{N} \text { atural Resources, Division of Water R esources } \\
\text { (State Engineer). }\end{array}$ & \\
\hline DatSrc & Data source & NSTec & National Security Technologies, LLC (NSTec). & \\
\hline DatSrc & Data source & RSN & Raytheon Services N evada (RSN). & \\
\hline DatSrc & Data source & SNJV & Stoller-N avarro J oint Venture (SNJV). & \\
\hline DatSrc & Data source & USGS & USGS. & \\
\hline RcdTypDsc & $\begin{array}{c}\text { Record type or } \\
\text { description }\end{array}$ & - & Record description and/or document type. & \\
\hline RcdTypDsc & $\begin{array}{l}\text { Record type or } \\
\text { description }\end{array}$ & BN/PF & B echtel N evada (BN) Project Files (PF). & \\
\hline RcdTypDsc & \begin{tabular}{|c|}
$\begin{array}{c}\text { Record type or } \\
\text { description }\end{array}$ \\
\end{tabular} & DTRA/PF & DOD, D efense Threat Reduction A gency (DTRA) Project Files (PF). & \\
\hline RcdTypDsc & $\begin{array}{l}\text { Record type or } \\
\text { description }\end{array}$ & $F \& S / P F$ & Fenix and Scisson, Inc. (F\& S) Project Files (PF). & \\
\hline
\end{tabular}


Table D1. Description of Fracture-Characteristic Database field contents.—Continued

[A ccess field names longer than 8 characters indicated by red text because longer names may be incompatible with some database and Graphic Information System (GIS) applications. Blank field source indicates not applicable, not available online, or not accessible to the public. A bbreviations: DOD, U.S. Department of Defense; DOE, U.S. Department of Energy; NTS, Nevada Test Site; NWIS, N ational Water Information System; USGS, U.S. Geological Survey; ft, foot; - , not applicable]

\begin{tabular}{|c|c|c|c|c|}
\hline Access field name & Excel field name & Field code & Field explanation & Field source \\
\hline RcdTypDsc & $\begin{array}{c}\text { Record type or } \\
\text { description }\end{array}$ & FSN/PF & Fenix and Scisson of Nevada (FSN) Project Files (PF). & \\
\hline RcdTypDsc & $\begin{array}{c}\text { Record type or } \\
\text { description }\end{array}$ & IT Corp./PF & International Technology Corporation (IT Corp.) Project Files (PF). & \\
\hline RcdTypDsc & $\begin{array}{c}\text { Record type or } \\
\text { description }\end{array}$ & LANL/PF & Los A lamos N ational Laboratory (LANL) Project Files (PF); referred to as "Blue Folders." & \\
\hline RcdTypDsc & $\begin{array}{c}\text { Record type or } \\
\text { description }\end{array}$ & LLNL/PF & L aw rence Livermore National Laboratory (LLNL) Project Files (PF). & \\
\hline RcdTypDsc & $\begin{array}{c}\text { Record type or } \\
\text { description }\end{array}$ & NDWR/WDR & State of Nevada, Division of Water Resources, Well D riller's Report (Well Log). & \\
\hline RcdTypDsc & $\begin{array}{c}\text { Record type or } \\
\text { description }\end{array}$ & NSTec/PF & National Security Technologies, LLC. (NSTec) Project Files (PF). & \\
\hline RcdTypDsc & $\begin{array}{c}\text { Record type or } \\
\text { description }\end{array}$ & RSN/PF & Raytheon Services N evada (RSN) Project Files (PF). & \\
\hline RcdTypDsc & $\begin{array}{c}\text { Record type or } \\
\text { description }\end{array}$ & SNJV/PF & Stoller-N avarro J oint Venture (SNJV) Project Files (PF). & \\
\hline RcdTypDsc & $\begin{array}{c}\text { Record type or } \\
\text { description }\end{array}$ & USGS/PF & USGS Project Files (PF). & \\
\hline RptRef & Report reference & - & $\begin{array}{l}\text { Published report that contains fracture-characteristic data. A complete list of acronyms and } \\
\text { abbreviations used in USG S and other reports is included in the usgs_rpt and nts acr abv } \\
\text { worksheets in the nts_fct_chr spreadsheet (appendix D). NOTE : [USG S Technical Letters } \\
\text { are considered internal correspondence and are not available for public release unless } \\
\text { the report has been assigned a USG S O pen-File Report number. Technical Letters } \\
\text { prepared under the USG S H ydrologic Resource M anagement Program (HR M P, formerly } \\
\text { Hydrology/R adionuclide M igration Program) and assigned "blanket open-file status" } \\
\text { are designated "USG S-474-number." Technical Letters prepared under the USG S Yucca } \\
\text { M ountain Program (YM P) and assigned "blanket open-file status" are designated "USG S- } \\
\text { 1543-number." Furthermore, some reports prepared by the National L aboratories and the } \\
\text { various DOE and DOD subcontractors also may be considered internal correspondence } \\
\text { and not available for public release. Users interested in these reports must check with the } \\
\text { source agency to determine availability]. }\end{array}$ & \\
\hline Invst & Investigators & - & A uthors and/or investigators. & \\
\hline LocIDLANL & $\begin{array}{l}\text { LANL_PGG Database } \\
\text { loc_id }\end{array}$ & - & $\begin{array}{l}\text { This unique symbol within the LA NL PGG database represents a specific, usually unique location } \\
\text { on the surface, or a specific, usually unique location within a tunnel. The dash character (-) is } \\
\text { reserved for sample ID s and therefore dashes in published locations are converted to a foreslash } \\
\text { (/). Thus } 11 / 102 / 7 A \text { is the loc id for a sample identified by its collector as 11-102-7-A. } \\
\text { Description updated from LAN L Report LA-UR-03-1503 (2003). }\end{array}$ & $\frac{\text { http://www.pggdb- }}{\text { swnvf.lanl.gov/ }}$ \\
\hline
\end{tabular}


Table D1. Description of Fracture-Characteristic Database field contents.-Continued

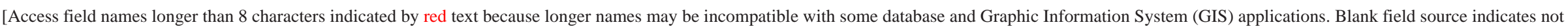

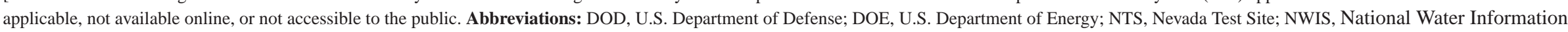
System; USGS, U.S. Geological Survey; ft, foot; - , not applicable]

\begin{tabular}{|c|c|c|c|c|}
\hline Access field name & Excel field name & Field code & Field explanation & Field source \\
\hline SamIDLANL & $\begin{array}{l}\text { LA NL PGG Database } \\
\text { sam_id }\end{array}$ & - & $\begin{array}{l}\text { This unique symbol within the LANL PG database represents up to a few kilograms of } \\
\text { contiguous material from the surface or subsurface. The dash special character (-) designates } \\
\text { multiple samples from a single location, and a left parenthesis '(' designates multiple splits from } \\
\text { a single sample. Samples from vertical drill holes will always have sam_id's represented by the } \\
\text { location, which is the drill hole name, followed by a dash (-) and the sample depth in feet, for } \\
\text { example, USW G2-770. Sample depths in meters attach "M " following the metric depth, for } \\
\text { example, USW G2-506.65M. M ultiple samples from the same location, for example a whole- } \\
\text { rock sample and several lithic and pumice separates, will always have sam_id's represented by } \\
\text { the location followed by a dash (-) and a character string, for example RW 18B 3-WR, RW 18B 3- } \\
\text { PU 1, and RW 18B 3-PU 2. D escription updated from LA NL R eport LA-UR-03-1503 (2003). }\end{array}$ & $\frac{\text { http://www.pggdb- }}{\text { swnvf.lanl.gov/ }}$ \\
\hline SpIIDLANL & $\begin{array}{l}\text { LA NL PGG Database } \\
\text { spl_id }\end{array}$ & - & $\begin{array}{l}\text { This unique symbol within the LA L PG G database represents a split of a sample for analysis. } \\
\text { A split represents analysis for one or more element or component that is performed by a single } \\
\text { laboratory. U sually, a few grams are split from the sample and specially prepared for the } \\
\text { analytical procedure, such as a glass-covered thin section for petrographic analysis or pulverized } \\
\text { rock for chemical analysis. Each thin section and each laboratory's chemical analysis represents } \\
\text { a separate split, even if the analyses are performed by different analysts on widely separated } \\
\text { dates. Each thin section represents a split, but each batch of sample pulverized for chemical } \\
\text { analysis does not. A left parenthesis '(' designates each split from a single sample, such as } \\
\text { B H86N/33(B, a polished thin section for sample B H86N/33. M ultiple chemical analyses of } \\
\text { the same sample by the same laboratory and multiple analyses of the same thin section are } \\
\text { considered to represent replicate analyses. To represent split analyses, replicate chemical } \\
\text { analyses are averaged, weighted by the inverse square of their analytical uncertainties. R eplicate } \\
\text { petrographic analyses are ranked; analyses of the same rank are averaged, weighted by the } \\
\text { number of points counted. Individual replicate analyses are not stored within the database, } \\
\text { but analysts and analytical dates and other information are provided with the analytical data. } \\
\text { Description updated from LA NL R eport LA -UR-03-1503 (2003). }\end{array}$ & $\begin{array}{l}\text { http://www.pggdb- } \\
\text { swnvf.lanl.gov/ }\end{array}$ \\
\hline RecL OC & Record location & - & Physical location of fracture-characteristic record. & \\
\hline HleTyp & Hole type & - & Type of vertical or horizontal drilling or excavation. & \\
\hline HleTyp & Hole type & B orehole & Vertical surface location; includes wells and vertical test holes. & \\
\hline HleTyp & Hole type & Crater & Vertical surface location. & \\
\hline HleTyp & Hole type & Drift & Horizontal underground location; includes tunnels and horizontal test holes. & \\
\hline HleTyp & Hole type & M ultiple Wells & M ultiple wells. & \\
\hline HleTyp & Hole type & Outcrop & Surface location. & \\
\hline HleTyp & Hole type & Shaft & Vertical surface location. & \\
\hline HleTyp & Hole type & Spring & Spring. & \\
\hline
\end{tabular}


Table D1. Description of Fracture-Characteristic Database field contents.—Continued

[A ccess field names longer than 8 characters indicated by red text because longer names may be incompatible with some database and Graphic Information System (GIS) applications. Blank field source indicates not applicable, not available online, or not accessible to the public. A bbreviations: DOD, U.S. Department of Defense; DOE, U.S. Department of Energy; NTS, Nevada Test Site; NWIS, N ational Water Information System; USGS, U.S. Geological Survey; ft, foot; - , not applicable]

\begin{tabular}{|c|c|c|c|c|}
\hline Access field name & Excel field name & Field code & Field explanation & Field source \\
\hline HleTyp & Hole type & Streambed & Streambed. & \\
\hline HleTyp & Hole type & Surface & Surface location. & \\
\hline HleTyp & Hole type & Trench & Horizontal surface location. & \\
\hline HleTyp & Hole type & Unknown & Hole type not known. & \\
\hline TnlDftConSta & $\begin{array}{l}\text { Tunnel or drift } \\
\text { construction station }\end{array}$ & - & $\begin{array}{l}\text { Construction station at collar location (portal opening), for tunnels and drifts (i.e. - } 9+17 \text { is } 917 \mathrm{ft} \text {; } \\
10+72,195^{\prime} \text { is a } 195 \mathrm{ft} \text { hole at the } 1,072 \mathrm{ft} \text { station; etc.). }\end{array}$ & \\
\hline ConStaRmk & $\begin{array}{l}\text { Construction station } \\
\text { remarks }\end{array}$ & - & $\begin{array}{l}\text { Remarks concerning the portal opening (collar location), for tunnels and drifts (i.e. - In U-12e.14 } \\
\text { main drift; A Icove; Face; Invert; Lft Rib; Rt Rib; etc.). }\end{array}$ & \\
\hline NVSPE27 & $\begin{array}{l}\text { Nevada SPCS Easting } \\
\text { NAD } 27\end{array}$ & - & $\begin{array}{l}\text { Nevada state plane coordinates (SPCS), Easting, central zone, in feet; N orth A merican D atum of } \\
1927 \text { (NA D 27). }\end{array}$ & \\
\hline NVSPN 27 & $\begin{array}{l}\text { Nevada SPCS N orthing } \\
\text { NAD 27 }\end{array}$ & - & $\begin{array}{l}\text { Nevada state plane coordinates (SPCS), N orthing, central zone, in feet; North A merican D atum of } \\
1927 \text { (NA D 27). }\end{array}$ & \\
\hline NVSPErr & SPCS error & - & SPCS error, in feet. Blank if unknown. & \\
\hline A ItPorOpn29ft & $\begin{array}{l}\text { A ltitude at portal } \\
\text { opening NGVD } 29 \\
\text { (ft) }\end{array}$ & - & $\begin{array}{l}\text { A ltitude at the collar location of the portal opening, for tunnels and drifts; in feet above mean sea } \\
\text { level; N ational G eodetic Vertical Datum of } 1929 \text { (NG V D 29). }\end{array}$ & \\
\hline BngPorOpnDeg & $\begin{array}{l}\text { Bearing from portal } \\
\text { opening (degrees) }\end{array}$ & - & $\begin{array}{l}\text { B earing from the portal opening, for tunnels and drifts; in degrees, minutes, and seconds } \\
\text { or decimal degrees (i.e. - S0720958W is South, } 72 \text { degrees, } 9 \text { minutes, } 58 \text { seconds West; } \\
\text { N } 0325529 \mathrm{E} \text { is N orth, } 32 \text { degrees, } 55 \text { minutes, } 29 \text { seconds East; N } 052.75 W \text { is North } 52 \text { and } \\
\text { three-quarter degrees West; etc.) }\end{array}$ & \\
\hline IncPorOpnD eg & $\begin{array}{c}\text { Inclination from portal } \\
\text { opening (degrees) }\end{array}$ & - & $\begin{array}{l}\text { Inclination from the portal opening, for tunnels and drifts; in degrees, minutes, and seconds or } \\
\text { decimal degrees (i.e. - } 0045825 \text { is a hole } 4 \text { degrees, } 58 \text { minutes, } 25 \text { seconds above horizontal; } \\
2700000 \text { is a vertical hole below horizontal; } 0900000 \text { is a vertical hole above horizontal; } \\
0000000 \text { and } 1800000 \text { are horizontal holes; } 0150000 \text { and } 1650000 \text { are holes } 15 \text { degrees up } \\
\text { (above horizontal); } 3150000 \text { and } 2250000 \text { are holes } 45 \text { degrees down (below horizontal); } 356.5 \\
\text { is a hole } 3 \text { and one-half degrees below horizontal; } 170.25 \text { is } 9 \text { and three-quarter degrees above } \\
\text { horizontal; etc.). Inclinations are linked to bearings, so values near horizontal for holes bearing } \\
\text { north or east would be added to zero for holes inclined above horizontal and subtracted from } \\
360 \text { for holes below horizontal; conversely, values near horizontal for holes bearing south or } \\
\text { west would be subtracted from } 180 \text { for holes inclined above horizontal and added to } 180 \text { for } \\
\text { holes below horizontal. }\end{array}$ & \\
\hline
\end{tabular}


Table D1. Description of Fracture-Characteristic Database field contents.-Continued

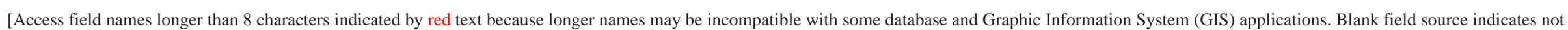

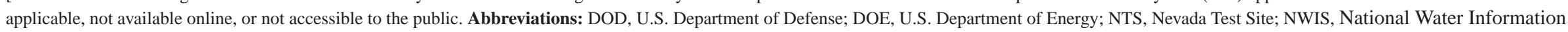
System; USGS, U.S. Geological Survey; ft, foot; - , not applicable]

\begin{tabular}{|c|c|c|c|c|}
\hline Access field name & Excel field name & Field code & Field explanation & Field source \\
\hline AltL ndSur29ft & $\begin{array}{l}\text { A Ititude of land surface } \\
\text { NGVD } 29 \text { (ft) }\end{array}$ & - & $\begin{array}{l}\text { A Ititude of land surface within a reasonable proximity of the site; in feet above mean sea level; } \\
\text { N ational Geodetic Vertical D atum of } 1929 \text { (N GV D 29). This is an average of the surrounding } \\
\text { ground-surface el evation. If the original surface has been altered, estimate the altitude based on } \\
\text { nearby unaltered terrain. }\end{array}$ & \\
\hline AltM th & Altitude method & - & M ethod used to determine altitude of land surface. & \\
\hline AltM th & Altitude method & A & A ltimeter. & \\
\hline AltM th & Altitude method & $\mathrm{D}$ & Differentially corrected Global Positioning System (DGPS). & \\
\hline AltM th & Altitude method & G & Global Positioning System (GPS). & \\
\hline AltM th & Altitude method & I & Interferometric Synthetic A perture Radar (IfSA R), airplane. & \\
\hline AltM th & Altitude method & J & Light Detection A nd R anging (LiDAR), airplane. & \\
\hline AltM th & Altitude method & $\mathrm{L}$ & Level or other surveying method. & \\
\hline AltM th & Altitude method & M & $\begin{array}{l}\text { Interpolated from topographic map [report accuracy as } \pm \text { one-half the contour interval (or } \\
\text { supplementary contour interval) specified on the quadrangle]. }\end{array}$ & \\
\hline AltM th & Altitude method & $\mathrm{N}$ & Interpolated from digital elevation model (DEM). & \\
\hline AltM th & Altitude method & $\mathrm{R}$ & Reported. & \\
\hline AltM th & Altitude method & $\mathrm{U}$ & Unknown. & \\
\hline AltAcc & Altitude accuracy & - & A ltitude accuracy; in feet (decimal values for accuracies less than $1 \mathrm{ft}$ ). & \\
\hline AltAcc & Altitude accuracy & $\mathrm{U}$ & Unknown. & \\
\hline SitCmpDt & Site completion date & - & Date hole construction completed. & \\
\hline HleD thft & Hole depth (ft) & - & $\begin{array}{l}\text { Hole depth; in feet bel ow land surface for boreholes and shafts; in feet from portal opening for } \\
\text { tunnels and drifts. }\end{array}$ & \\
\hline
\end{tabular}


Table D1. Description of Fracture-Characteristic Database field contents.—Continued

[Access field names longer than 8 characters indicated by red text because longer names may be incompatible with some database and Graphic Information System (GIS) applications. B lank field source indicates not applicable, not available online, or not accessible to the public. Abbreviations: DOD, U.S. Department of Defense; DOE, U.S. Department of Energy; NTS, N evada Test Site; NWIS, N ational Water Information System; USGS, U.S. Geological Survey; ft, foot; -, not applicable]

\begin{tabular}{|c|c|c|c|c|}
\hline Access field name & Excel field name & Field code & Field explanation & Field source \\
\hline RedBkHleNo & Redbook hole number & - & $\begin{array}{l}\text { Redbook hole numbers are currently assigned to new holes completed at the NTS by National } \\
\text { Security Technologies, LLC (NSTec). Entries are listed in bold type where sites are located in } \\
\text { areas other than the hole name implies. }\end{array}$ & \\
\hline RedBkHleNo & Redbook hole number & - & $\begin{array}{l}\text { Redbook hole numbers listed in the Raytheon Services N evada (RSN) N evada Test Site Drilling } \\
\text { and M ining Summary (last updated 12-31-90) and previously in the Fenix and Scisson of } \\
\text { Nevada N TS D rilling and M ining Summary (last updated 06-30-89; formerly Fenix and } \\
\text { Scisson, Inc.) were assigned according to the type of hole drilled or mined, site location (NTS } \\
\text { area), and sequence code for the consecutive order in which the hole was drilled, mined, or } \\
\text { recompleted. Emplacement holes for nuclear weapons tests begin with the letter U, followed } \\
\text { by a dash (-), NTS area number (fig. 1), and sequence code (letters a-z, aa-az, ba-bz, ..., za- } \\
\text { zz). Exploratory holes follow the same naming convention as emplacement holes, but begin } \\
\text { with the letters UE. Holes that begin with the letter U but were drilled or mined specifically to } \\
\text { provide data that could not be collected from an emplacement hole follow the emplacement } \\
\text { hole naming convention, but are assigned incremental letters or numbers, or both following } \\
\text { the sequence code. The suffix letters indicate: [\#, satellite hole; CH, cable hole; Ex. or Expl., } \\
\text { exploratory hole; HTH, hydrologic test hole; Inst., instrument hole; ITS, integrated test system; } \\
\text { PPS, pre-postshot hole; PS, post-shot hole; R N M, radionuclide migration hole; RW M S, } \\
\text { radioactive waste management site; and S, substitute hole]. There are numerous exceptions } \\
\text { to the standard naming convention. The prefix letters indicate: [HTH, hydrologic test hole; J, } \\
\text { Jackass Flat; and R N M, radionuclide migration]. Numbers and letters following the dash in } \\
\text { the exceptions represent sequence of site drilling or mining, not NTS location. Hole type also } \\
\text { is commonly listed after the hole designation. For example: [Access Shaft; Cable Hole; Expl. } \\
\text { Hole; Instrument; LOS (Line Of Sight) D rift; Sidetrack; Reentry M ining; Tunnel; Vent Hole; } \\
\text { and Zero Station]. }\end{array}$ & \\
\hline RedB kHleNo & Redbook hole number & - & $\begin{array}{l}\text { USGS D OE project-related holes in Central N evada follow a similar naming convention. How ever, } \\
\text { emplacement holes begin with the letters UC and exploratory holes begin with the letters U CE. }\end{array}$ & \\
\hline RedB kHleNo & Redbook hole number & - & $\begin{array}{l}\text { USG S Y ucca M ountain Project (Y M P) holes at the NTS follow the exploratory hole naming } \\
\text { convention. Offsite Y M P holes begin with the letters USW to indicate underground southern } \\
\text { Nevada waste. The suffix letters indicate: [G, geologic hole; GA, geologic angle hole; GU, } \\
\text { geologic unsaturated zone hole; H, hydrologic hole; M X, missile-experimental hole (drilled for } \\
\text { U.S. A ir Force [USA F] M X M issile-Siting Investigation); N, neutron hole; p, Paleozoic or pre- } \\
\text { Tertiary hole; RF, repository facility hole; UZ, unsaturated zone hole; V, volcanic hole; VSE, } \\
\text { vertical shelter exploratory hole (drilled for USA F M X M issile-Siting Investigation); and WT, } \\
\text { water table hole]. }\end{array}$ & \\
\hline
\end{tabular}


Table D1. Description of Fracture-Characteristic Database field contents.-Continued

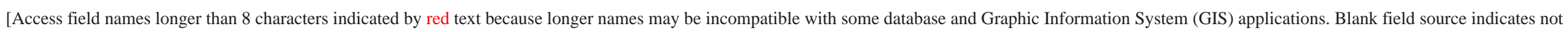

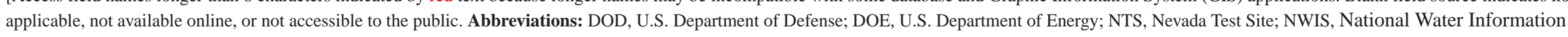
System; USGS, U.S. Geological Survey; ft, foot; -, not applicable]

\begin{tabular}{|c|c|c|c|c|}
\hline Access field name & Excel field name & Field code & Field explanation & Field source \\
\hline RedB kHleNo & Redbook hole number & - & $\begin{array}{l}\text { Environmental Restoration Program (ERP) holes at the NTS begin with the letters ER, followed } \\
\text { by a dash, NTS area number (fig. 1), a dash, and an incremental sequence number. The NTS } \\
\text { area number is replaced by suffix letters for ERP holes located offsite. The suffix letters } \\
\text { indicate: [EC, area at the USA F N ellis Air Force Base Range (NAFBR) where the holes were } \\
\text { drilled; and OV, O asis Valley]. }\end{array}$ & \\
\hline RedB kHleN o & Redbook hole number & - & 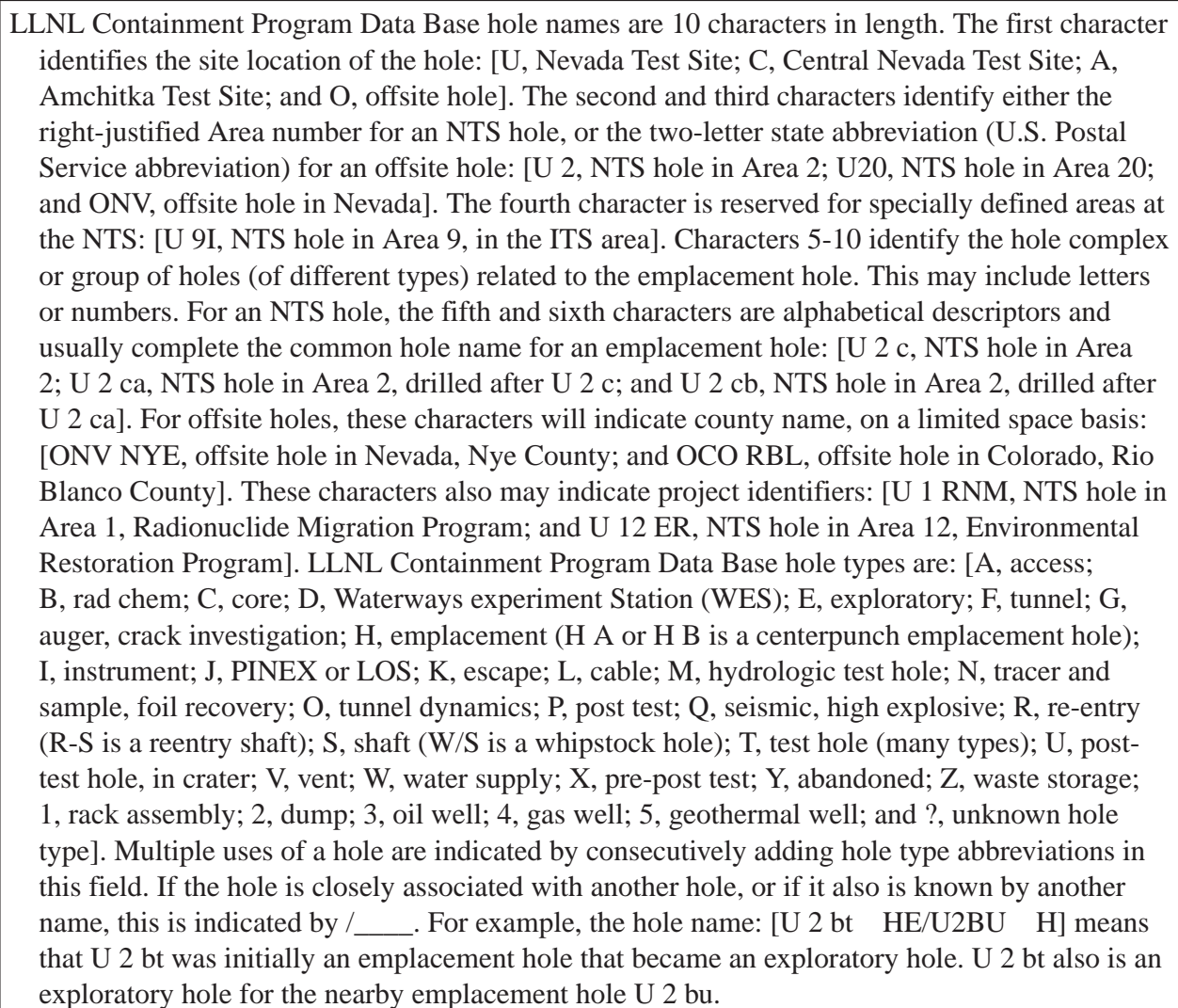 & \\
\hline
\end{tabular}


Table D1. Description of Fracture-Characteristic Database field contents.-Continued

[A ccess field names longer than 8 characters indicated by red text because longer names may be incompatible with some database and Graphic Information System (GIS) applications. B lank field source indicates not applicable, not available online, or not accessible to the public. Abbreviations: DOD, U.S. Department of Defense; DOE, U.S. Department of Energy; NTS, N evada Test Site; NWIS, N ational Water Information System; USGS, U.S. Geological Survey; ft, foot; - , not applicable]

\begin{tabular}{|c|c|c|c|c|}
\hline Access field name & Excel field name & Field code & Field explanation & Field source \\
\hline FmrOthH leN me & $\begin{array}{l}\text { Former or other hole } \\
\text { name }\end{array}$ & - & Former or other names utilized for holes. & \\
\hline A gyCdU SGSN WIS & NWIS agency code & USGS & $\begin{array}{l}\text { USGS NWIS code to indicate the reporting agency. All sites currently populated in the fracture- } \\
\text { characteristic database are assigned as USGS. }\end{array}$ & \\
\hline SitIDNoUSGSNWIS & $\begin{array}{l}\text { NW IS site } \\
\text { identification } \\
\text { number }\end{array}$ & - & USGS N WIS site identification number. & \\
\hline SitID NoU SGSNW IS & $\begin{array}{l}\text { NW IS site } \\
\text { identification } \\
\text { number }\end{array}$ & - & $\begin{array}{l}\text { Downstream order numbers are assigned for surface-water, on-stream, sites. The first two digits } \\
\text { of the station number indicate the part or major drainage system formerly used for U SG S } \\
\text { Water-Supply Papers entitled "Surface Water Supply of the United States" and the remaining } \\
\text { digits indicate the downstream order within the part. This site number is left-justified. A Ithough } \\
\text { downstream identification numbers have been converted to a variable length format, with up to } \\
14 \text { digits available, } 8 \text { digits are normally assigned. }\end{array}$ & \\
\hline SitI D NoUSGSN WIS & $\begin{array}{l}\text { NW IS site } \\
\text { identification } \\
\text { number }\end{array}$ & - & $\begin{array}{l}\text { Numbering system for sites on open water bodies, off-channel sites, wells, springs, etc., is based } \\
\text { on the grid system of latitude and longitude. Although this number is initially determined from } \\
\text { the best known latitude/longitude location, plus a } 2 \text {-digit sequence number for the number of } \\
\text { sites located at those coordinates, it retains no locational relevance once the site is created in the } \\
\text { database. The overall designation consists of } 15 \text { digits. The values of latitude and longitude are } \\
\text { updated as better coordinates become available, and should al ways be used for locating sites or } \\
\text { plotting locations. }\end{array}$ & \\
\hline Lat27 & Latitude NA D 27 & - & $\begin{array}{l}\text { Latitude; in degrees, minutes, and seconds [two digits are available for decimal seconds]; N orth } \\
\text { A merican D atum of } 1927 \text { (NAD 27). }\end{array}$ & \\
\hline Lng27 & Longitude NA D 27 & - & $\begin{array}{l}\text { L ongitude; in degrees, minutes, and seconds [two digits are available for decimal seconds]; N orth } \\
\text { A merican D atum of } 1927 \text { (NAD 27). }\end{array}$ & \\
\hline LocM th & Location method & - & M ethod used to determine latitude and longitude coordinates. & \\
\hline LocM th & Location method & C & Calculated from land net. & \\
\hline LocM th & Location method & $\mathrm{D}$ & Differentially corrected G lobal Positioning System (D GPS). & \\
\hline LocM th & Location method & G & $\begin{array}{l}\text { Global positioning system (GPS), uncorrected [Standard Positioning Service (SPS) and Precise } \\
\text { Positioning Service (PPS)]. }\end{array}$ & \\
\hline LocM th & Location method & L & L ong-range navigation (L oran) system. & \\
\hline LocM th & Location method & M & Interpolated from map. & \\
\hline LocM th & Location method & $\mathrm{N}$ & Interpolated from digital map. & \\
\hline LoCM th & Location method & $\mathrm{R}$ & Reported. & \\
\hline LocM th & Location method & $\mathrm{S}$ & Transit, theodolite, or other surveying method. & \\
\hline
\end{tabular}


Table D1. Description of Fracture-Characteristic Database field contents.-Continued

[A ccess field names longer than 8 characters indicated by red text because longer names may be incompatible with some database and Graphic Information System (GIS) applications. B lank field source indicates not applicable, not available online, or not accessible to the public. A bbreviations: DOD, U.S. Department of Defense; DOE, U.S. Department of Energy; NTS, Nevada Test Site; NWIS, National Water Information System; USGS, U.S. Geological Survey; ft, foot; -, not applicable]

\begin{tabular}{|c|c|c|c|c|}
\hline Access field name & Excel field name & Field code & Field explanation & Field source \\
\hline LocM th & Location method & U & Unknown. & \\
\hline LoCACC & Location accuracy & -- & Accuracy of latitude and longitude coordinates. & \\
\hline L OCACC & Location accuracy & $\mathrm{H}$ & Hundredth second. & \\
\hline LOCACC & Location accuracy & 1 & Tenth second. & \\
\hline LOCACC & Location accuracy & 5 & Half second. & \\
\hline LoCACC & Location accuracy & $\mathrm{S}$ & Second. & \\
\hline LOCACC & Location accuracy & $\mathrm{R}$ & Three seconds. & \\
\hline LOCACC & Location accuracy & $\mathrm{F}$ & Five seconds. & \\
\hline LOCACC & Location accuracy & $T$ & Ten seconds. & \\
\hline LOCACC & Location accuracy & M & M inute. & \\
\hline LOCACC & Location accuracy & $\mathrm{U}$ & Unknown. & \\
\hline DecLat83 & $\begin{array}{l}\text { Decimal latitude } \\
\text { NAD 83 }\end{array}$ & - & $\begin{array}{l}\text { Latitude, in decimal degrees [automatically generated by the N WIS system software]; N orth } \\
\text { A merican Datum of } 1983 \text { (NA D 83). }\end{array}$ & \\
\hline DecLng83 & $\begin{array}{l}\text { Decimal longitude } \\
\text { NA D83 }\end{array}$ & - & $\begin{array}{l}\text { L ongitude, in decimal degrees [automatically generated by NW IS system software]; North } \\
\text { A merican D atum of } 1983 \text { (NA D 83). }\end{array}$ & \\
\hline UTME $27 \mathrm{~m}$ & $\begin{array}{l}\text { UTM Easting NAD } 27 \\
\text { (meters) }\end{array}$ & - & $\begin{array}{l}\text { U niversal Transverse M ercator coordinates, Easting, zone 11, in meters; North A merican Datum } \\
\text { of } 1927 \text { (NA D 27). }\end{array}$ & \\
\hline UTM N 27m & $\begin{array}{l}\text { UTM N orthing NAD } 27 \\
\text { (meters) }\end{array}$ & - & $\begin{array}{l}\text { U niversal Transverse M ercator coordinates, Northing, zone 11, in meters; N orth A merican Datum } \\
\text { of } 1927 \text { (NA D 27). }\end{array}$ & \\
\hline UTMErr & UTM error & - & UTM error, in meters. Blank if unknown. & \\
\hline Rmk & Remarks & - & Pertinent remarks pertaining to the fracture characteristics. & \\
\hline DtRcdL stU pd & $\begin{array}{l}\text { Date record last } \\
\text { updated }\end{array}$ & - & $\begin{array}{l}\text { D ate of data entry (compiled into electronic format) is listed if a row of record has not been } \\
\text { modified. The date of last (most recent) update is listed if a row of record has been modified. } \\
\text { This date does not indicate which columns of data have been modified; only that records have } \\
\text { been updated within a particular row. Dates are listed as yyyymmdd (4-digit year; 2-digit } \\
\text { month; 2-digit day). }\end{array}$ & \\
\hline URLAdr & URL address & - & Link to online website and database. & \\
\hline
\end{tabular}




\section{Appendix E. Hydraulic-Property Database, Nevada Test Site and Vicinity, Nye County, Nevada.}

Hydraulic-property data were compiled for both underground and surface sites located on and around the NTS. A ppendix E data are available at URL: http://pubs.usgs. gov/ds/2007/297/.

Table E1. Description of Hydraulic-Property Database field contents.

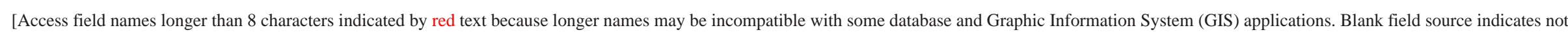

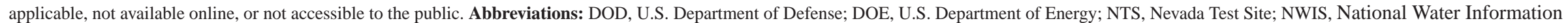
System; USGS, U.S. Geological Survey; ft, foot; - , not applicable]

\begin{tabular}{|c|c|c|c|c|}
\hline Access field name & Excel field name & Field code & Field explanation & Field source \\
\hline SrtOrdUSGS & USGS NTS sort order & - & $\begin{array}{l}\text { Emplacement and exploratory holes typically are displayed together. M any sites also have } \\
\text { multiple completion intervals within the same hole. Therefore, a sort order number is assigned } \\
\text { to all USGS sites associated with DOE and/or DOD projects in N evada. This field is modified } \\
\text { as new sites are added. }\end{array}$ & \\
\hline UnqNoUSGS & $\begin{array}{l}\text { USGS NTS unique } \\
\text { number }\end{array}$ & - & $\begin{array}{l}\text { Spatial }(X-Y) \text { coordinates are unavailable at some locations. Therefore, USGS site identification } \\
\text { numbers cannot be established in the USGS N WIS database Sitefile for these sites. B ecause } \\
\text { N WIS site identification numbers cannot be assigned to all sites, it is necessary to assign a } \\
\text { unique site number to all USGS sites associated with USGS DOE/DOD projects in N evada. } \\
\text { A Ithough the unique numbers were initially assigned in the same order as the USGS NTS sort } \\
\text { order, new sites are assigned the next available sequential number. }\end{array}$ & \\
\hline NTSA rea & NTS area & - & $\begin{array}{l}\text { NTS A dministrative A rea number (see fig. 1). Entries are listed in bold type where sites are } \\
\text { located in areas other than the hole name implies. For example, USGS hole name UE -10j is } \\
\text { actually located in NTS area } \mathbf{0 8 .}\end{array}$ & \\
\hline HleN meUSGS & USGS hole name & - & $\begin{array}{l}\text { USGS hole name designation. Entries are listed in bold type where sites are located in areas other } \\
\text { than the hole name implies. }\end{array}$ & \\
\hline HleTstSeq & $\begin{array}{l}\text { Hole test sequence } \\
\text { number }\end{array}$ & - & $\begin{array}{l}\text { Sequence of testing conducted at each specific borehole or drift, listed in ascending order by date } \\
\text { and time. }\end{array}$ & \\
\hline TstlntNo & Test interval number & - & Sequence of tested interval. & \\
\hline TstlntSeq & $\begin{array}{l}\text { Test interval sequence } \\
\text { number }\end{array}$ & - & Sequence of tests, when multiple tests are reported within a test interval. & \\
\hline TstlntTopft & Test interval top (ft) & - & $\begin{array}{l}\text { Depth to top of tested interval; in feet below land surface for boreholes and shafts; in feet from } \\
\text { portal opening for tunnels and drifts. }\end{array}$ & \\
\hline TstlntB tmft & Test interval bottom (ft) & - & $\begin{array}{l}\text { Depth to bottom of tested interval; in feet bel ow land surface for boreholes and shafts; in feet from } \\
\text { portal opening for tunnels and drifts. }\end{array}$ & \\
\hline TstN 0 & Test number & - & Number or zone of test, as recorded on field sheets. & \\
\hline TstTyp & Test type & - & Typical testing types are: bailing, injection, laboratory, pumping, and swabbing. & \\
\hline
\end{tabular}


Table E1. Description of Hydraulic-Property Database field contents.-Continued

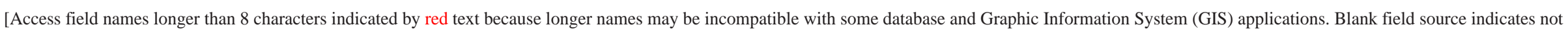

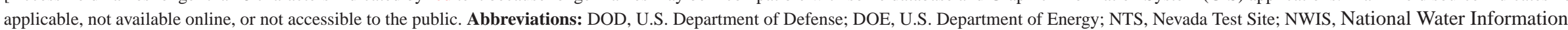
System; USGS, U.S. Geological Survey; ft, foot; -, not applicable]

\begin{tabular}{|c|c|c|c|c|}
\hline Access field name & Excel field name & Field code & Field explanation & Field source \\
\hline TstPhs & Test phase & - & Phases of testing are: initializing, injection, pumping, recovery, suspended, and swabbing. & \\
\hline TstR unN 0 & Test run number & - & Cumulative number of swabbing runs or trips in the borehole. & \\
\hline TstDur & Test duration & - & L ength of test; as hours, minutes, and seconds. & \\
\hline TstR mk & Test remarks & - & Pertinent comments concerning test data. & \\
\hline RtY IdTst & Test rate or yield & - & Y ield or rate of injection. & \\
\hline RtY IdUntTst & Test rate or yield units & - & $\begin{array}{l}\text { The conversion factor [448.83117] is used to convert between gallons per minute (gpm) and cubic } \\
\text { feet per second (cfs). }\end{array}$ & \\
\hline RtY IdRmkTst & $\begin{array}{l}\text { Test rate or yield } \\
\text { remarks }\end{array}$ & - & Pertinent comments concerning rate or yield data. & \\
\hline RdgFlwmtr & Flowmeter reading & - & Totalizing flowmeter readings. & \\
\hline UntFIwmtr & Flowmeter units & - & N ormally gallons [(325,851 gallons $=1$ acre-foot) and (gallons $* 3.78533=$ liters)]. & \\
\hline RmkFlwmtr & Flowmeter remarks & - & Pertinent comments concerning flowmeter data. & \\
\hline RdgStfGg & Staff gauge reading & - & Depth to water in storage tank used for injection of water. & \\
\hline UntStfGg & Staff gauge units & - & N ormally feet [feet $* 0.3048=$ meters]. & \\
\hline RmkStfGg & Staff gauge remarks & - & Pertinent comments concerning staff gage data. & \\
\hline QTst & Test quantity & - & Total quantity withdrawn from or injected into the borehole. & \\
\hline QUntT st & Test quantity units & - & N ormally gallons [(325,851 gallons = 1 acre-foot) and (gallons $* 3.78533=$ liters)]. & \\
\hline QRmkTst & Test quantity remarks & - & Pertinent comments concerning quantity data. & \\
\hline CalcDtTm & Calculated date/time & - & $\begin{array}{l}\text { Calculated from data contained in the following Date, Time, and Elapsed or cumulative time } \\
\text { fields. }\end{array}$ & \\
\hline Date & Date & - & Calendar date, as century, year, month, and day. & \\
\hline Time & Time & - & Clock time (24-hour-or- military), as hour and minute. & \\
\hline TmElapsCum & $\begin{array}{l}\text { Elapsed or cumulative } \\
\text { time }\end{array}$ & - & Elapsed or cumulative time, in minutes, since testing or recovery commenced. & \\
\hline WLBIWMP & $\begin{array}{l}\text { D epth to water below } \\
\text { measuring point }\end{array}$ & - & $\begin{array}{l}\text { D epth-to-water measurement, in feet or meters bel ow the measuring point ["-----" indicates time } \\
\text { listed but no water level recorded or other activity performed]. }\end{array}$ & \\
\hline WLUnt01 & Depth to water units & - & N ormally meters [meters / $0.3048=$ feet]. & \\
\hline WLRmk01 & Depth to water remarks & - & Pertinent comments concerning depth-to-water data. & \\
\hline RdgA irlnGg & A irline gauge reading & - & N ormally pounds per square inch. & \\
\hline UntA irlnGg & A irline gauge units & - & M ultiply psi * 2.31 to convert to feet of water. & \\
\hline RmkA irlnGg & A irline gauge remarks & - & Pertinent comments concerning airline data. & \\
\hline
\end{tabular}


Table E1. Description of Hydraulic-Property Database field contents.-Continued

[A ccess field names longer than 8 characters indicated by red text because longer names may be incompatible with some database and Graphic Information System (GIS) applications. Blank field source indicates not applicable, not available online, or not accessible to the public. A bbreviations: DOD, U.S. Department of Defense; DOE, U.S. Department of Energy; NTS, Nevada Test Site; NWIS, National Water Information System; USGS, U.S. Geological Survey; ft, foot; - , not applicable]

\begin{tabular}{|c|c|c|c|c|}
\hline Access field name & Excel field name & Field code & Field explanation & Field source \\
\hline StatWLB IwM P & $\begin{array}{l}\text { Static water level below } \\
\text { measuring point }\end{array}$ & - & Static (undisturbed) water level. & \\
\hline TstW L BIwM P & $\begin{array}{l}\text { Testing water level } \\
\text { below measuring } \\
\text { point }\end{array}$ & - & M aximum water level during testing. & \\
\hline WLUnt02 & Water level units & - & Normally feet [feet $* 0.3048=$ meters]. & \\
\hline WLRmk02 & Water level remarks & - & Pertinent comments concerning water-level data. & \\
\hline Drawdown & Drawdown & - & Change in depth to water during testing. & \\
\hline UntDraw down & Draw down units & - & Normally meters [meters / $0.3048=$ feet]. & \\
\hline RmkDrawdown & Draw down remarks & - & Pertinent comments concerning drawdown data. & \\
\hline TypPacker & Packer type & - & M anufacturer or model name of straddle-packer tool. & \\
\hline DiamPacker & Packer diameter & - & Uninflated diameter of packer unit. & \\
\hline SpacePacker & Packer spacing & - & Distance between bottom of upper and top of lower packer. & \\
\hline UntPacker & Packer units & - & Normally inches and feet [feet $* 0.3048=$ meters]. & \\
\hline RmkPacker & Packer remarks & - & Pertinent comments concerning straddle-packer data. & \\
\hline TypPump & Pump type & - & M anufacturer or model name of pump. & \\
\hline IntDthPump & Pump intake depth & - & Depth to pump intake. & \\
\hline UntPump & Pump units & - & Normally feet [feet $* 0.3048=$ meters]. & \\
\hline RmkPump & Pump remarks & - & Pertinent comments concerning pump data. & \\
\hline SizeStorTnk & Storage tank size & - & Dimensions of storage tank, as width $\times$ length $\times$ height. & \\
\hline SizeUntStorTnk & Storage tank size units & - & Normally feet [feet $* 0.3048=$ meters]. & \\
\hline CapStorTnk & Storage tank capacity & - & Volume of water storage tank will hold. & \\
\hline CapUntStorTnk & $\begin{array}{l}\text { Storage tank capacity } \\
\text { units }\end{array}$ & - & Normally gallons [( 325,851 gallons $=1$ acre-foot) and (gallons * $3.78533=$ liters) $].$ & \\
\hline RmkStorTnk & Storage tank remarks & - & Pertinent comments concerning storage tank data. & \\
\hline DthQL $n$ & Discharge line depth & - & Depth to bottom of discharge line. & \\
\hline DthUntQLn & $\begin{array}{l}\text { Discharge line depth } \\
\text { units }\end{array}$ & - & Normally feet [feet $* 0.3048=$ meters]. & \\
\hline SzQLn & Discharge line size & - & Inside diameter (if available) of discharge line. & \\
\hline SzUntQLn & Discharge line size units & - & Normally inches [Divide by 12 and multiply by 0.3048 to obtain meters]. & \\
\hline RefQLn & Discharge line reference & - & Note whether diameter is expressed as inside or outside dimensions. & \\
\hline CapQLn & Discharge line capacity & - & Volume of water discharge line will transmit. & \\
\hline
\end{tabular}


Table E1. Description of Hydraulic-Property Database field contents.-Continued

[A ccess field names longer than 8 characters indicated by red text because longer names may be incompatible with some database and Graphic Information System (GIS) applications. B lank field source indicates not applicable, not available online, or not accessible to the public. Abbreviations: DOD, U.S. Department of Defense; DOE, U.S. Department of Energy; NTS, Nevada Test Site; NWIS, N ational Water Information System; USGS, U.S. Geological Survey; ft, foot; -, not applicable]

\begin{tabular}{|c|c|c|c|c|}
\hline Access field name & Excel field name & Field code & Field explanation & Field source \\
\hline CapUntQLn & $\begin{array}{l}\text { Discharge line capacity } \\
\text { units }\end{array}$ & - & Normally listed as gallons per foot. & \\
\hline RmkQLn & Discharge line remarks & - & Pertinent comments concerning discharge line data. & \\
\hline SpecCap & Specific capacity & - & Y ield per unit of draw down. & \\
\hline UntSpecCap & Specific capacity units & - & Normally expressed as gallons per minute per foot of draw down. & \\
\hline RmkSpecCap & $\begin{array}{l}\text { Specific capacity } \\
\text { remarks }\end{array}$ & - & Pertinent comments concerning specific capacity data. & \\
\hline Sath ydC ond & $\begin{array}{l}\text { Saturated hydraulic } \\
\text { conductivity }\end{array}$ & - & Saturated hydraulic conductivity (water movement through saturated media). & \\
\hline HydCondUnt & $\begin{array}{l}\text { Hydraulic conductivity } \\
\text { units }\end{array}$ & - & Reporting units. & \\
\hline HydCondM th & $\begin{array}{l}\text { Hydraulic conductivity } \\
\text { method }\end{array}$ & - & M ethod used to measure hydraulic conductivity. & \\
\hline HydCondRmk & $\begin{array}{l}\text { Hydraulic conductivity } \\
\text { remarks }\end{array}$ & - & Pertinent comments concerning hydraulic conductivity data. & \\
\hline TW tr & Temperature water & - & Water temperature, as degrees. & \\
\hline TIntlWtr & $\begin{array}{l}\text { Temperature initial } \\
\text { water }\end{array}$ & - & Initial (pre-testing) water temperature, as degrees. & \\
\hline TM axW tr & $\begin{array}{l}\text { Temperature maximum } \\
\text { water }\end{array}$ & - & M aximum water temperature, as degrees. & \\
\hline TUnt & Temperature units & - & Normally Celsius [(Celsius $* 1.8)+32=$ Fahrenheit]. & \\
\hline TRmk & Temperature remarks & - & Pertinent comments concerning temperature data. & \\
\hline CondW tr & Conductivity water & - & Specific conductance (reciprocal of resistivity) of the water. & \\
\hline CondUnt & Conductivity units & - & $\begin{array}{l}\text { Reporting units are micromhos per centimeter [micromhos have been renamed to the numerically } \\
\text { equival ent microsiemens]. }\end{array}$ & \\
\hline CondRmk & Conductivity remarks & - & Pertinent comments concerning specific conductance data. & \\
\hline pHWtr & pH water & - & $\begin{array}{l}\text { Hydrogen ion activity (concentration); expressed as the negative base-10 log of the hydrogen-ion } \\
\text { activity, in moles per liter. }\end{array}$ & \\
\hline pHRmk & pH remarks & - & Pertinent comments concerning pH data. & \\
\hline M ajProdZn & $\begin{array}{l}\text { M ajor producing } \\
\text { zone(s) }\end{array}$ & - & Depth(s) to top and bottom of major a major producing zone(s). & \\
\hline LthM ajProdZn & $\begin{array}{l}\text { M ajor producing zone } \\
\text { lithology }\end{array}$ & - & Lithologic description or stratigraphic unit adjacent to major producing zone(s). & \\
\hline
\end{tabular}


Table E1. Description of Hydraulic-Property Database field contents.-Continued

[A ccess field names longer than 8 characters indicated by red text because longer names may be incompatible with some database and Graphic Information System (GIS) applications. Blank field source indicates not applicable, not available online, or not accessible to the public. Abbreviations: DOD, U.S. Department of Defense; DOE, U.S. Department of Energy; NTS, Nevada Test Site; NWIS, National Water Information System; USGS, U.S. Geological Survey; ft, foot; - , not applicable]

\begin{tabular}{|c|c|c|c|c|}
\hline Access field name & Excel field name & Field code & Field explanation & Field source \\
\hline UntM ajProdZn & $\begin{array}{l}\text { Major producing zone } \\
\text { units }\end{array}$ & - & Normally feet [feet $* 0.3048=$ meters]. & \\
\hline RmkM ajProdZn & $\begin{array}{l}\text { M ajor producing zone } \\
\text { remarks }\end{array}$ & - & Pertinent comments concerning major producing zone data. & \\
\hline ElvRP29ft & $\begin{array}{l}\text { R eference point } \\
\text { elevation NGVD } 29 \\
\text { (ft) }\end{array}$ & - & $\begin{array}{l}\text { Elevation of reference (measuring) point, in feet above mean sea level; National Geodetic Vertical } \\
\text { D atum of } 1929 \text { (N G V D 29). }\end{array}$ & \\
\hline H eightR P & Reference point height & - & Height of reference (measuring) point, in feet above land surface. & \\
\hline DscRP & $\begin{array}{l}\text { Reference point } \\
\text { description }\end{array}$ & - & Description of the reference (measuring) point. & \\
\hline UntRP & Reference point units & - & Normally feet [feet $* 0.3048=$ meters]. & \\
\hline RmkRP & $\begin{array}{l}\text { Reference point } \\
\text { remarks }\end{array}$ & - & Pertinent comments concerning measuring point data. & \\
\hline AnlyzA gy & A nalyzing agency & - & A gency that performed the sample analyses. & \\
\hline A nlyzA gy & A nalyzing agency & Birdwell & Birdwell Division of Seismograph Service Corporation (SSC). & \\
\hline A nlyzA gy & A nalyzing agency & BN & B echtel N evada (BN). & \\
\hline A nlyzA gy & A nalyzing agency & $\mathrm{CL}$ & Core Laboratories, Inc. (CL), B akersfield, California; Dallas, Texas. & \\
\hline A nlyzA gy & A nalyzing agency & DTRA & DOD, D efense Threat Reduction A gency (DTRA). & \\
\hline A nlyzA gy & A nalyzing agency & DRI & Desert Research Institute (DRI). & \\
\hline A nlyzA gy & A nalyzing agency & DS & Daniel B. Stephens and A ssociates, Inc. (DS), A lbuquerque, NM. & \\
\hline A nlyzA gy & A nalyzing agency & $F \& S$ & Fenix and Scisson, Inc. (F\&S). & \\
\hline A nlyzA gy & A nalyzing agency & FSN & Fenix and Scisson of Nevada (FSN). & \\
\hline A nlyzA gy & A nalyzing agency & $H \& N$ & Holmes and Narver, Inc. (H\&N). & \\
\hline A nlyzA gy & A nalyzing agency & LANL & Los A lamos National Laboratory (LANL). & \\
\hline A nlyzA gy & A nalyzing agency & LLNL & Law rence Livermore National Laboratory (LLNL). & \\
\hline A nlyzA gy & A nalyzing agency & NSTec & National Security Technologies, LLC (NSTec). & \\
\hline A nlyzA gy & A nalyzing agency & NTL & Nevada Testing Laboratories, LTD. (NTL). & \\
\hline A nlyzA gy & A nalyzing agency & PTL & Pittsburgh Testing Laboratory (PTL), Salt Lake City, Utah. & \\
\hline A nlyzA gy & A nalyzing agency & REECO & Reynolds Electrical and Engineering Company (REECo). & \\
\hline A nlyzA gy & A nalyzing agency & RSN & Raytheon Services N evada (RSN). & \\
\hline AnlyzA gy & A nalyzing agency & SNL & Sandia National Laboratories (SNL). & \\
\hline
\end{tabular}


Table E1. Description of Hydraulic-Property Database field contents.-Continued

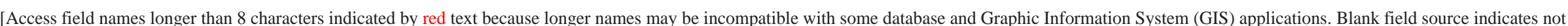

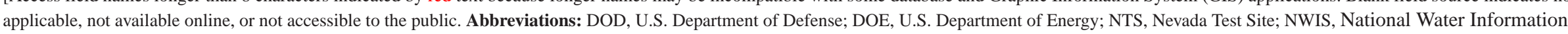
System; USGS, U.S. Geological Survey; ft, foot; -, not applicable]

\begin{tabular}{|c|c|c|c|c|}
\hline Access field name & Excel field name & Field code & Field explanation & Field source \\
\hline A nlyzA gy & A nalyzing agency & TT & $\begin{array}{l}\text { Terra Tek, Inc. (TT), Salt L ake City, U tah, a Schlumberger company; sometimes referred to as } \\
\text { TerraTek Research. }\end{array}$ & \\
\hline A nlyzA gy & A nalyzing agency & UI & U niversity of Illinois (UI). & \\
\hline A nlyzA gy & A nalyzing agency & USACE & U.S. A rmy Corps of Engineers (USACE). & \\
\hline A nlyzA gy & A nalyzing agency & USGS & USGS. & \\
\hline DatSrc & Data source & - & A gency that reported hydraulic-property data. & \\
\hline DatSrc & Data source & BN & B echtel N evada (BN). & \\
\hline DatSrc & Data source & DTRA & DOD, D efense Threat Reduction A gency (DTRA). & \\
\hline DatSrc & Data source & DRI & D esert R esearch Institute (DRI). & \\
\hline DatSrc & D ata source & DS & Daniel B. Stephens and A ssociates, Inc. (DS), A Ibuquerque, NM. & \\
\hline DatSrc & Data source & $F \& S$ & Fenix and Scisson, Inc. (F\& S). & \\
\hline DatSrc & Data source & FSN & Fenix and Scisson of N evada (FSN). & \\
\hline DatSrc & Data source & IT Corp. & International Technology Corporation (IT Corp., purchased by Shaw Group, Inc.). & \\
\hline DatSrc & Data source & LANL & Los A lamos National Laboratory (LA NL). & \\
\hline DatSrc & Data source & LLNL & Lawrence Livermore N ational Laboratory (LLNL). & \\
\hline DatSrc & Data source & NSTec & National Security Technologies, LLC (NSTec). & \\
\hline DatSrc & Data source & RSN & Raytheon Services N evada (RSN). & \\
\hline DatSrc & Data source & SNJV & Stoller-N avarro J oint Venture (SNJV). & \\
\hline DatSrc & Data source & USGS & USGS. & \\
\hline RcdTypDsc & \begin{tabular}{|c|}
$\begin{array}{c}\text { Record type or } \\
\text { description }\end{array}$ \\
\end{tabular} & - & Record description and/or document type. & \\
\hline RcdTypDsc & $\begin{array}{l}\text { Record type or } \\
\text { description }\end{array}$ & $\mathrm{BN} / \mathrm{PF}$ & B echtel N evada (BN) Project Files (PF). & \\
\hline RcdTypDsc & \begin{tabular}{|c|c} 
Record type or \\
description
\end{tabular} & DTRA/PF & DOD, D efense Threat R eduction A gency (DTRA) Project Files (PF). & \\
\hline RcdTypDsc & $\begin{array}{l}\text { Record type or } \\
\text { description }\end{array}$ & $\mathrm{DRI} / \mathrm{PF}$ & D esert R esearch Institute (DRI) Project Files (PF). & \\
\hline RcdTypDsc & \begin{tabular}{|c} 
Record type or \\
description
\end{tabular} & $\mathrm{DS} / \mathrm{LR}$ & Daniel B. Stephens and A ssociates, Inc. (DS) L aboratory Report (LR). & \\
\hline RcdTypDsc & $\begin{array}{c}\text { Record type or } \\
\text { description }\end{array}$ & $F \& S / P F$ & Fenix and Scisson, Inc. (F\& S) Project Files (PF). & \\
\hline RcdTypDsc & $\begin{array}{l}\text { Record type or } \\
\text { description }\end{array}$ & $\mathrm{FSN} / \mathrm{PF}$ & Fenix and Scisson of N evada (FSN) Project Files (PF). & \\
\hline
\end{tabular}


Table E1. Description of Hydraulic-Property Database field contents. - Continued

[A ccess field names longer than 8 characters indicated by red text because longer names may be incompatible with some database and Graphic Information System (GIS) applications. Blank field source indicates not applicable, not available online, or not accessible to the public. Abbreviations: DOD, U.S. Department of Defense; DOE, U.S. Department of Energy; NTS, Nevada Test Site; NWIS, National Water Information System; USGS, U.S. Geological Survey; ft, foot; -, not applicable]

\begin{tabular}{|c|c|c|c|c|}
\hline Access field name & Excel field name & Field code & Field explanation & Field source \\
\hline RcdTypDsc & $\begin{array}{c}\text { Record type or } \\
\text { description }\end{array}$ & IT Corp./PF & International Technology Corporation (IT Corp.) Project Files (PF). & \\
\hline RcdTypDsc & $\begin{array}{c}\text { Record type or } \\
\text { description }\end{array}$ & LANL/PF & Los A lamos N ational Laboratory (LA NL) Project Files (PF); referred to as "Blue Folders." & \\
\hline RcdTypDsc & $\begin{array}{c}\text { Record type or } \\
\text { description }\end{array}$ & LLNL/PF & L aw rence Livermore National Laboratory (LLNL) Project Files (PF). & \\
\hline RcdTypDsc & $\begin{array}{c}\text { Record type or } \\
\text { description }\end{array}$ & NSTec/PF & National Security Technologies, LLC. (NSTec) Project Files (PF). & \\
\hline RcdTypDsc & $\begin{array}{c}\text { Record type or } \\
\text { description }\end{array}$ & RSN/PF & Raytheon Services N evada (RSN) Project Files (PF). & \\
\hline RcdTypDsc & $\begin{array}{c}\text { Record type or } \\
\text { description }\end{array}$ & SNJV/PF & Stoller-Navarro J oint Venture (SNJV) Project Files (PF). & \\
\hline RcdTypDsc & $\begin{array}{c}\text { Record type or } \\
\text { description }\end{array}$ & USGS/PF & USGS Project Files (PF). & \\
\hline RptR ef & Report reference & - & $\begin{array}{l}\text { Published report that contains hydraulic-property data. A complete list of acronyms and } \\
\text { abbreviations used in USGS and other reports is included in the usgs rpt and nts acr abv } \\
\text { worksheets in the nts_hyd_pty spreadsheet (appendix E). NOTTE : [USGS Technical Letters } \\
\text { are considered internal correspondence and are not available for public release unless } \\
\text { the report has been assigned a USG S O pen-File R eport number. Technical L etters } \\
\text { prepared under the USG S Hydrologic R esource M anagement Program (H R M P, formerly } \\
\text { Hydrology/Radionuclide M igration Program) and assigned "blanket open-file status" } \\
\text { are designated "USG S-474-number." Technical Letters prepared under the USG S Yucca } \\
\text { M ountain Program (Y M P) and assigned "blanket open-file status" are designated } \\
\text { "USG S-1543-number." Furthermore, some reports prepared by the National Laboratories } \\
\text { and the various DOE and DOD subcontractors may also be considered internal } \\
\text { correspondence and not available for public release. Users interested in these reports must } \\
\text { check with the source agency to determine availability]. }\end{array}$ & \\
\hline Invst & Investigators & - & A uthors and/or investigators. & \\
\hline RecL oc & Record location & - & Physical location of hydraulic-property record. & \\
\hline HleTyp & Hole type & - & Type of vertical or horizontal drilling or excavation. & \\
\hline HleTyр & Hole type & Borehole & Vertical surface location; includes wells and vertical test holes. & \\
\hline HleTyp & Hole type & Crater & Vertical surface location. & \\
\hline HleTyp & Hole type & Drift & Horizontal underground location; includes tunnels and horizontal test holes. & \\
\hline HleTyp & Hole type & Multiple Wells & M ultiple wells. & \\
\hline HleTyp & Hole type & Outcrop & Surface location. & \\
\hline HleTyp & Hole type & Shaft & Vertical surface location. & \\
\hline
\end{tabular}


Table E1. Description of Hydraulic-Property Database field contents.-Continued

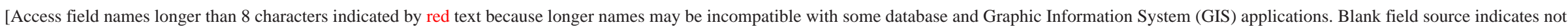

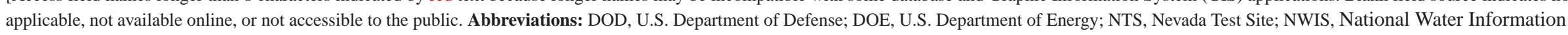
System; USGS, U.S. Geological Survey; ft, foot; -, not applicable]

\begin{tabular}{|c|c|c|c|c|}
\hline Access field name & Excel field name & Field code & Field explanation & Field source \\
\hline HleTyp & Hole type & Spring & Spring. & \\
\hline HleTyp & Hole type & Streambed & Streambed. & \\
\hline HleTyp & Hole type & Surface & Surface location. & \\
\hline HleTyp & Hole type & Trench & Horizontal surface location. & \\
\hline HleTyp & Hole type & Unknown & Hole type not known. & \\
\hline TnlDftConSta & $\begin{array}{l}\text { Tunnel or drift } \\
\text { construction station }\end{array}$ & - & $\begin{array}{l}\text { Construction station at collar location (portal opening), for tunnels and drifts (i.e. - } 9+17 \text { is } 917 \mathrm{ft} \text {; } \\
10+72,195^{\prime} \text { is a } 195 \mathrm{ft} \text { hole at the } 1,072 \mathrm{ft} \text { station; etc.). }\end{array}$ & \\
\hline ConStaRmk & $\begin{array}{l}\text { Construction station } \\
\text { remarks }\end{array}$ & - & $\begin{array}{l}\text { Remarks concerning the portal opening (collar location), for tunnels and drifts (i.e. - In U-12e.14 } \\
\text { main drift; A lcove; Face; Invert; Lft Rib; Rt Rib; etc.). }\end{array}$ & \\
\hline NVSPE 27 & $\begin{array}{l}\text { N evada SPCS E asting } \\
\text { NAD } 27\end{array}$ & - & $\begin{array}{l}\text { N evada state plane coordinates (SPCS), Easting, central zone, in feet; North A merican Datum of } \\
1927 \text { (NAD 27). }\end{array}$ & \\
\hline NVSPN 27 & $\begin{array}{l}\text { N evada SPCS N orthing } \\
\text { NAD } 27\end{array}$ & - & $\begin{array}{l}\text { N evada state plane coordinates (SPCS), N orthing, central zone, in feet; N orth A merican Datum of } \\
1927 \text { (NAD 27). }\end{array}$ & \\
\hline NV SPErr & SPCS error & - & SPCS error, in feet. Blank if unknown. & \\
\hline AltPorOpn29ft & $\begin{array}{l}\text { A ltitude at portal } \\
\text { opening NGVD } 29 \\
\text { (ft) }\end{array}$ & - & $\begin{array}{l}\text { A ltitude at the collar location of the portal opening, for tunnels and drifts; in feet above mean sea } \\
\text { level; N ational Geodetic Vertical Datum of } 1929 \text { (NGV D29). }\end{array}$ & \\
\hline BngPorOpnDeg & $\begin{array}{l}\text { B earing from portal } \\
\text { opening (degrees) }\end{array}$ & - & $\begin{array}{l}\text { B earing from the portal opening, for tunnels and drifts; in degrees, minutes, and seconds } \\
\text { or decimal degrees (i.e. - S0720958W is South, } 72 \text { degrees, } 9 \text { minutes, } 58 \text { seconds West; } \\
\text { N } 0325529 \mathrm{E} \text { is N orth, } 32 \text { degrees, } 55 \text { minutes, } 29 \text { seconds E ast; N 052.75W is N orth } 52 \text { and } \\
\text { three-quarter degrees West; etc.) }\end{array}$ & \\
\hline IncPorOpnDeg & $\begin{array}{l}\text { Inclination from portal } \\
\text { opening (degrees) }\end{array}$ & - & $\begin{array}{l}\text { Inclination from the portal opening, for tunnels and drifts; in degrees, minutes, and seconds or } \\
\text { decimal degrees (i.e. - } 0045825 \text { is a hole } 4 \text { degrees, } 58 \text { minutes, } 25 \text { seconds above horizontal; } \\
2700000 \text { is a vertical hole below horizontal; } 0900000 \text { is a vertical hole above horizontal; } \\
0000000 \text { and } 1800000 \text { are horizontal holes; } 0150000 \text { and } 1650000 \text { are holes } 15 \text { degrees up } \\
\text { (above horizontal); } 3150000 \text { and } 2250000 \text { are holes } 45 \text { degrees down (below horizontal); } 356.5 \\
\text { is a hole } 3 \text { and one-half degrees bel ow horizontal; } 170.25 \text { is } 9 \text { and three-quarter degrees above } \\
\text { horizontal; etc.). Inclinations are linked to bearings, so values near horizontal for holes bearing } \\
\text { north or east would be added to zero for holes inclined above horizontal and subtracted from } \\
360 \text { for holes below horizontal; conversely, values near horizontal for holes bearing south or } \\
\text { west would be subtracted from } 180 \text { for holes inclined above horizontal and added to } 180 \text { for } \\
\text { holes below horizontal. }\end{array}$ & \\
\hline
\end{tabular}


Table E1. Description of Hydraulic-Property Database field contents.-Continued

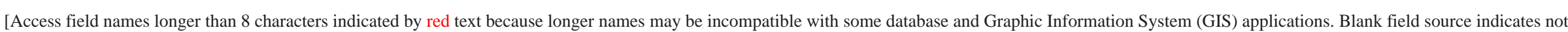

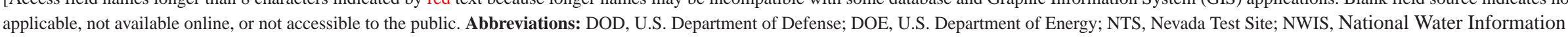
System; USGS, U.S. Geological Survey; ft, foot; -, not applicable]

\begin{tabular}{|c|c|c|c|c|}
\hline Access field name & Excel field name & Field code & Field explanation & Field source \\
\hline A ItL ndSur29ft & $\begin{array}{l}\text { Altitude of land surface } \\
\text { NGVD29 (ft) }\end{array}$ & - & $\begin{array}{l}\text { A ltitude of land surface within a reasonable proximity of the site; in feet above mean sea level; } \\
\text { National G eodetic Vertical Datum of } 1929 \text { (N GV D 29). This is an average of the surrounding } \\
\text { ground-surface elevation. If the original surface has been altered, estimate the altitude based on } \\
\text { nearby unaltered terrain. }\end{array}$ & \\
\hline AltM th & Altitude method & - & M ethod used to determine altitude of Iand surface. & \\
\hline AltM th & Altitude method & A & Altimeter. & \\
\hline AltM th & Altitude method & $\mathrm{D}$ & Differentially corrected Global Positioning System (DGPS). & \\
\hline A ItM th & Altitude method & G & Global Positioning System (GPS). & \\
\hline AltM th & Altitude method & 1 & Interferometric Synthetic A perture R adar (IfSA R), airplane. & \\
\hline AltM th & Altitude method & J & Light D etection A nd R anging (LiDA R), airplane. & \\
\hline AltM th & Altitude method & $\mathrm{L}$ & Level or other surveying method. & \\
\hline AltM th & Altitude method & M & $\begin{array}{l}\text { Interpolated from topographic map [report accuracy as } \pm \text { one-half the contour interval (or } \\
\text { supplementary contour interval) specified on the quadrangle]. }\end{array}$ & \\
\hline AltM th & Altitude method & $\mathrm{N}$ & Interpolated from digital elevation model (DEM). & \\
\hline AltM th & Altitude method & $\mathrm{R}$ & Reported. & \\
\hline AltM th & Altitude method & U & Unknown. & \\
\hline AltA $c$ C & Altitude accuracy & - & Altitude accuracy; in feet (decimal values for accuracies less than $1 \mathrm{ft}$ ). & \\
\hline AltA $c$ C & Altitude accuracy & U & Unknown. & \\
\hline SitC mpDt & Site completion date & - & Date hole construction completed. & \\
\hline HleD thft & Hole depth (ft) & - & $\begin{array}{l}\text { Hole depth; in feet below land surface for boreholes and shafts; in feet from portal opening for } \\
\text { tunnels and drifts. }\end{array}$ & \\
\hline RedB kHleNo & Redbook hole number & - & $\begin{array}{l}\text { Redbook hole numbers are currently assigned to new holes completed at the NTS by National } \\
\text { Security Technologies, LLC (N STec). Entries are listed in bold type where sites are located in } \\
\text { areas other than the hole name implies. }\end{array}$ & \\
\hline
\end{tabular}


Table E1. Description of Hydraulic-Property Database field contents.-Continued

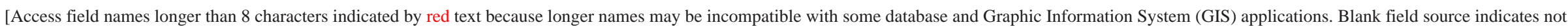

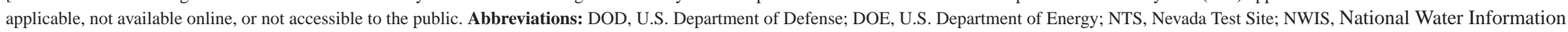
System; USGS, U.S. Geological Survey; ft, foot; - , not applicable]

\begin{tabular}{|c|c|c|c|c|}
\hline Access field name & Excel field name & Field code & Field explanation & Field source \\
\hline RedB kHleNo & Redbook hole number & - & $\begin{array}{l}\text { Redbook hole numbers listed in the R aytheon Services Nevada (RSN) Nevada Test Site D rilling } \\
\text { and M ining Summary (last updated 12-31-90) and previously in the Fenix and Scisson of } \\
\text { N evada NTS Drilling and M ining Summary (last updated 06-30-89; formerly Fenix and } \\
\text { Scisson, Inc.) were assigned according to the type of hole drilled or mined, site location (NTS } \\
\text { area), and sequence code for the consecutive order in which the hole was drilled, mined, or } \\
\text { recompleted. E mplacement holes for nuclear weapons tests begin with the letter U, followed } \\
\text { by a dash (-), N TS area number (fig. 1), and sequence code (letters a-z, aa-az, ba-bz, ..., za- } \\
\text { zz). Exploratory holes follow the same naming convention as emplacement holes, but begin } \\
\text { with the letters UE. H oles that begin with the letter U but were drilled or mined specifically to } \\
\text { provide data that could not be collected from an emplacement hole follow the emplacement } \\
\text { hole naming convention, but are assigned incremental letters or numbers, or both following } \\
\text { the sequence code. The suffix letters indicate: [\#, satellite hole; CH, cable hole; Ex. or Expl., } \\
\text { exploratory hole; HTH, hydrologic test hole; Inst., instrument hole; ITS, integrated test system; } \\
\text { PPS, pre-postshot hole; PS, post-shot hole; R N M , radionuclide migration hole; RW M S, } \\
\text { radioactive waste management site; and S, substitute hole]. There are numerous exceptions } \\
\text { to the standard naming convention. The prefix letters indicate: [HTH, hydrologic test hole; J, } \\
\text { Jackass Flat; and R NM , radionuclide migration]. N umbers and letters following the dash in } \\
\text { the exceptions represent sequence of site drilling or mining, not NTS location. Hole type al so } \\
\text { is commonly listed after the hole designation. For example: [A ccess Shaft; Cable H ole; Expl. } \\
\text { Hole; Instrument; L OS (Line Of Sight) Drift; Sidetrack; Reentry M ining; Tunnel; Vent Hole; } \\
\text { and Zero Station]. }\end{array}$ & \\
\hline RedB kHleNo & R edbook hole number & - & $\begin{array}{l}\text { USGS DOE project-related holes in Central Nevada follow a similar naming convention. However } \\
\text { emplacement holes begin with the letters UC and exploratory holes begin with the letters UCE. }\end{array}$ & \\
\hline RedB kHleNo & Redbook hole number & - & $\begin{array}{l}\text { U SGS Yucca M ountain Project (Y M P) holes at the NTS follow the exploratory hole naming } \\
\text { convention. Offsite Y M P holes begin with the letters USW to indicate underground southern } \\
\text { N evada waste. The suffix letters indicate: [G, geologic hole; GA, geologic angle hole; GU, } \\
\text { geologic unsaturated zone hole; H, hydrologic hole; M X, missile-experimental hole (drilled for } \\
\text { U.S. Air Force [USA F] M X M issile-Siting Investigation); N, neutron hole; p, Paleozoic or pre- } \\
\text { Tertiary hole; RF, repository facility hole; UZ, unsaturated zone hole; V, volcanic hole; V SE, } \\
\text { vertical shelter exploratory hole (drilled for USA F M X M issile-Siting Investigation); and WT, } \\
\text { water table hole]. }\end{array}$ & \\
\hline RedB kHleNo & Redbook hole number & - & $\begin{array}{l}\text { Environmental Restoration Program (ERP) holes at the NTS begin with the letters ER, followed } \\
\text { by a dash, NTS area number (fig. 1), a dash, and an incremental sequence number. The NTS } \\
\text { area number is replaced by suffix letters for ERP holes located offsite. The suffix letters } \\
\text { indicate: [EC, area at the USAF N ellis Air Force B ase Range (NA FBR) where the holes were } \\
\text { drilled; and OV, Oasis Valley]. }\end{array}$ & \\
\hline
\end{tabular}


Table E1. Description of Hydraulic-Property Database field contents.-Continued

[A ccess field names longer than 8 characters indicated by red text because longer names may be incompatible with some database and Graphic Information System (GIS) applications. Blank field source indicates not applicable, not available online, or not accessible to the public. Abbreviations: DOD, U.S. Department of Defense; DOE, U.S. Department of Energy; NTS, N evada Test Site; NWIS, N ational Water Information System; USGS, U.S. Geological Survey; ft, foot; - , not applicable]

\begin{tabular}{|c|c|c|c|c|}
\hline Access field name & Excel field name & Field code & Field explanation & Field source \\
\hline RedB kHleNo & Redbook hole number & - & 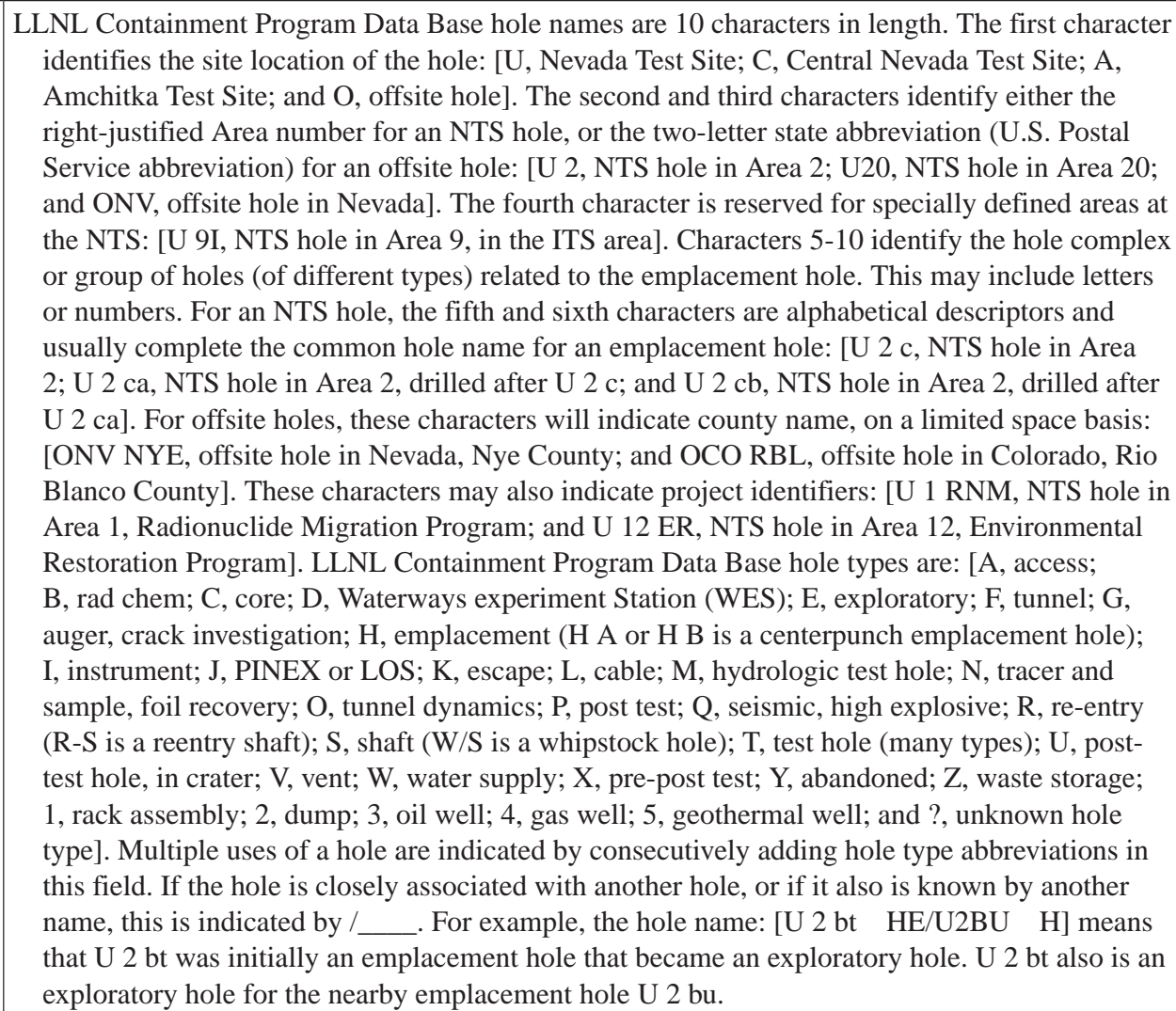 & \\
\hline FmrOthHleN me & $\begin{array}{l}\text { Former or other hole } \\
\text { name }\end{array}$ & - & Former or other names utilized for holes. & \\
\hline AgyCdUSGSNWIS & NWIS agency code & USGS & $\begin{array}{l}\text { USGS N WIS code to indicate the reporting agency. All sites currently populated in the hydraulic- } \\
\text { property database are assigned as USGS. }\end{array}$ & \\
\hline SitIDNoUSGSNWIS & $\begin{array}{c}\text { NWIS site identification } \\
\text { number }\end{array}$ & - & USGS N WIS site identification number. & \\
\hline
\end{tabular}


Table E1. Description of Hydraulic-Property Database field contents.-Continued

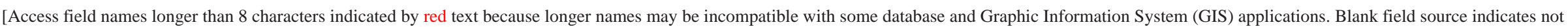

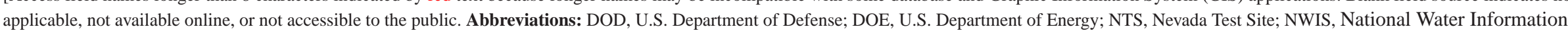
System; USGS, U.S. Geological Survey; ft, foot; -, not applicable]

\begin{tabular}{|c|c|c|c|c|}
\hline Access field name & Excel field name & Field code & Field explanation & Field source \\
\hline SitIDN oU SGSNWIS & $\begin{array}{l}\text { NWIS site identification } \\
\text { number }\end{array}$ & - & $\begin{array}{l}\text { D ownstream order numbers are assigned for surface-water, on-stream, sites. The first two digits } \\
\text { of the station number indicate the part or major drainage system formerly used for USGS } \\
\text { Water-Supply Papers entitled "Surface Water Supply of the U nited States" and the remaining } \\
\text { digits indicate the downstream order within the part. This site number is left-justified. A Ithough } \\
\text { downstream identification numbers have been converted to a variable length format, with up to } \\
14 \text { digits available, } 8 \text { digits are normally assigned. }\end{array}$ & \\
\hline SitIDN oU SGSN WIS & $\begin{array}{l}\text { NWIS site identification } \\
\text { number }\end{array}$ & - & $\begin{array}{l}\text { N umbering system for sites on open water bodies, off-channel sites, wells, springs, etc., is based } \\
\text { on the grid system of latitude and longitude. A lthough this number is initially determined from } \\
\text { the best known latitude/longitude location, plus a 2-digit sequence number for the number of } \\
\text { sites located at those coordinates, it retains no locational rel evance once the site is created in the } \\
\text { database. The overall designation consists of } 15 \text { digits. The values of latitude and longitude are } \\
\text { updated as better coordinates become available, and should always be used for locating sites or } \\
\text { plotting locations. }\end{array}$ & \\
\hline Lat27 & L atitude NA D 27 & - & $\begin{array}{l}\text { L atitude; in degrees, minutes, and seconds [two digits are available for decimal seconds]; North } \\
\text { A merican Datum of } 1927 \text { (NA D27). }\end{array}$ & \\
\hline Lng27 & Longitude NAD 27 & - & $\begin{array}{l}\text { Longitude; in degrees, minutes, and seconds [two digits are available for decimal seconds]; N orth } \\
\text { A merican Datum of } 1927 \text { (NA D 27). }\end{array}$ & \\
\hline LocM th & Location method & - & M ethod used to determine latitude and longitude coordinates. & \\
\hline LocM th & Location method & C & Calculated from land net. & \\
\hline LocM th & Location method & D & Differentially corrected Global Positioning System (DGPS). & \\
\hline LocM th & L ocation method & G & $\begin{array}{l}\text { G lobal positioning system (GPS), uncorrected [Standard Positioning Service (SPS) and Precise } \\
\text { Positioning Service (PPS)]. }\end{array}$ & \\
\hline LocM th & Location method & $\mathrm{L}$ & L ong-range navigation (L oran) system. & \\
\hline LocM th & Location method & M & Interpolated from map. & \\
\hline LocM th & Location method & $\mathrm{N}$ & Interpolated from digital map. & \\
\hline LocM th & Location method & $\mathrm{R}$ & Reported. & \\
\hline LocM th & Location method & S & Transit, theodolite, or other surveying method. & \\
\hline LocM th & L ocation method & U & Unknown. & \\
\hline LOCA CC & Location accuracy & - & A ccuracy of latitude and longitude coordinates. & \\
\hline LOCACC & Location accuracy & $\mathrm{H}$ & H undredth second. & \\
\hline LOCA CC & Location accuracy & 1 & Tenth second. & \\
\hline LOCACC & Location accuracy & 5 & Half second. & \\
\hline LOCACC & Location accuracy & $\mathrm{S}$ & Second. & \\
\hline LOCACC & Location accuracy & $\mathrm{R}$ & Three seconds. & \\
\hline
\end{tabular}


Table E1. Description of Hydraulic-Property Database field contents.-Continued

[A ccess field names longer than 8 characters indicated by red text because longer names may be incompatible with some database and Graphic Information System (GIS) applications. Blank field source indicates not applicable, not available online, or not accessible to the public. Abbreviations: DOD, U.S. Department of Defense; DOE, U.S. Department of Energy; NTS, Nevada Test Site; NWIS, N ational Water Information System; USGS, U.S. Geological Survey; ft, foot; - , not applicable]

\begin{tabular}{|c|c|c|c|c|}
\hline Access field name & Excel field name & Field code & Field explanation & Field source \\
\hline LOCACC & Location accuracy & $\mathrm{F}$ & Five seconds. & \\
\hline LoCACC & Location accuracy & $T$ & Ten seconds. & \\
\hline LOCACC & Location accuracy & M & M inute. & \\
\hline LOCACC & Location accuracy & U & Unknown. & \\
\hline DecL at83 & $\begin{array}{l}\text { Decimal latitude } \\
\text { NAD 83 }\end{array}$ & - & $\begin{array}{l}\text { Latitude, in decimal degrees [automatically generated by the NWIS system software]; N orth } \\
\text { A merican D atum of } 1983 \text { (NAD 83). }\end{array}$ & \\
\hline DecLng83 & $\begin{array}{l}\text { Decimal longitude } \\
\text { NAD } 83\end{array}$ & - & $\begin{array}{l}\text { L ongitude, in decimal degrees [automatically generated by N WIS system software]; North } \\
\text { A merican D atum of } 1983 \text { (NAD 83). }\end{array}$ & \\
\hline UTME $27 \mathrm{~m}$ & $\begin{array}{l}\text { UTM Easting NAD27 } \\
\text { (meters) }\end{array}$ & - & $\begin{array}{l}\text { Universal Transverse M ercator coordinates, Easting, zone 11, in meters; N orth A merican Datum } \\
\text { of } 1927 \text { (NA D 27). }\end{array}$ & \\
\hline UTMN $27 \mathrm{~m}$ & $\begin{array}{l}\text { UTM Northing NAD27 } \\
\text { (meters) }\end{array}$ & - & $\begin{array}{l}\text { Universal Transverse M ercator coordinates, N orthing, zone 11, in meters; N orth A merican Datum } \\
\text { of } 1927 \text { (NA D27). }\end{array}$ & \\
\hline UTMErr & UTM error & - & UTM error, in meters. Blank if unknown. & \\
\hline Rmk & Remarks & - & Pertinent remarks pertaining to the hydraulic properties. & \\
\hline DtRcdL stU pd & Date record last updated & - & $\begin{array}{l}\text { Date of data entry (compiled into electronic format) is listed if a row of record has not been } \\
\text { modified. The date of last (most recent) update is listed if a row of record has been modified. } \\
\text { This date does not indicate which columns of data have been modified; only that records have } \\
\text { been updated within a particular row. Dates are listed as yyyymmdd (4-digit year; 2-digit } \\
\text { month; 2-digit day). }\end{array}$ & \\
\hline URLAdr & URL address & - & Link to online website and database. & \\
\hline
\end{tabular}


Digitally Available Interval-Specific Rock-Sample Data Compiled from Historical Records, Nevada Test Site, Nevada

This page left intentionally blank 


\section{Appendix F. NTS USGS Databases, Nevada Test Site and Vicinity, Nye County, Nevada.}

M ost redundant data have been removed from the rock-sample, lithologic-description, rock-property, fracture-characteristic, and hydraulic-property tables and moved into a separate site-characteristic table. These data tables were developed in $\mathrm{M}$ icrosoft ${ }^{\circ} \mathrm{Excel}$ as stand-al one databases and are offered in $\mathrm{M}$ icrosoft ${ }^{\circ} \mathrm{Access}$ for quicker response time. The UnqN oUSGS field links the tables and the redundant SrtOrdUSGS field is retained in each table to maintain intended sort order. Furthermore, the redundant M apU ntSym, L ocIDLA NL, SamIDLA NL, and SpIIDLA NL fields are retained in the rock-sample, lithologic-description, and fracture-characteristic tables for both informational and linking purposes. The UnqN oUSGS field also is listed prior to the SrtOrdUSGS field in the hydraulic-property table for sorting purposes. Field contents are the same as described in tables A 1-E 1. H ow ever, the Site-Characteristic D atabase table includes additional fields described below. A ppendix F data are available at URL: http://pubs.usgs.gov/ds/2007/2971.

Table F1. Description of Site-Characteristic Database field contents.

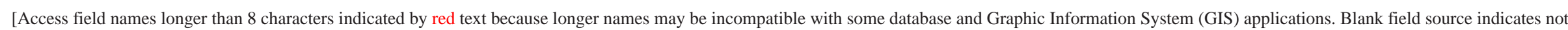

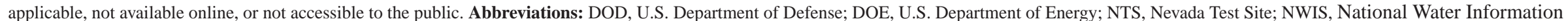
System; USGS, U.S. Geological Survey; ft, foot; -, not applicable]

\begin{tabular}{|c|c|c|c|c|}
\hline Access field name & Excel field name & Field code & Field explanation & Field source \\
\hline SrtOrdUSGS & USGS NTS sort order & - & $\begin{array}{l}\text { Emplacement and exploratory holes typically are displayed together. M any sites also have } \\
\text { multiple completion intervals within the same hole. Therefore, a sort order number is } \\
\text { assigned to all USGS sites associated with DOE and/or DOD projects in N evada. This field } \\
\text { is modified as new sites are added. }\end{array}$ & \\
\hline UnqNoUSGS & USGS NTS unique number & - & $\begin{array}{l}\text { Spatial (X-Y) coordinates are unavailable at some locations. Therefore, USGS site } \\
\text { identification numbers can not be established in the USGS NWIS database Sitefile for } \\
\text { these sites. B ecause N WIS site identification numbers can not be assigned to all sites, it is } \\
\text { necessary to assign a unique site number to all USGS sites associated with USGS DOE/DOD } \\
\text { projects in N evada. A Ithough the unique numbers were initially assigned in the same order } \\
\text { as the USGS NTS sort order, new sites are assigned the next available sequential number. }\end{array}$ & \\
\hline DtU nqN oA sgn & $\begin{array}{l}\text { Date unique number } \\
\text { assigned }\end{array}$ & - & $\begin{array}{l}\text { Date USGS NTS unique number assigned; as yyyymmdd (4-digit year; 2-digit month; 2-digit } \\
\text { day). }\end{array}$ & \\
\hline NTSA rea & NTS area & - & $\begin{array}{l}\text { NTS A dministrative A rea number (see fig. 1). Entries are listed in bold type where sites are } \\
\text { located in areas other than the hole name implies. For example, USGS hole name } \mathbf{U} \text { - } 2 \text { ao is } \\
\text { actually located in NTS area } 09 .\end{array}$ & \\
\hline HleN meUSGS & USGS hole name & - & $\begin{array}{l}\text { USGS hole name designation. Entries are listed in bold type where sites are located in areas } \\
\text { other than the hole name implies. }\end{array}$ & \\
\hline FmrOthHleN me & Former or other hole name & - & Former or other names utilized for holes. & \\
\hline HstFleSmpSitN meU SGS & $\begin{array}{l}\text { USGS historical file sample } \\
\text { site name }\end{array}$ & - & $\begin{array}{l}\text { Name listed on original site record contained in historical files located in the USGS M ercury } \\
\text { Core Library at the NTS or the USGS Office in Henderson, N evada. }\end{array}$ & \\
\hline SitSrc & Site source & - & Source of site data. & \\
\hline
\end{tabular}


Table F1. Description of Site-Characteristic Database field contents.-Continued

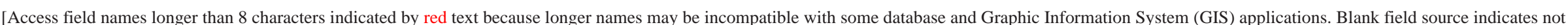

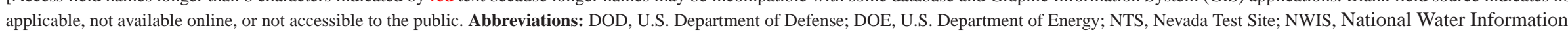
System; USGS, U.S. Geological Survey; ft, foot; -, not applicable]

\begin{tabular}{|c|c|c|c|c|}
\hline Access field name & Excel field name & Field code & Field explanation & Field source \\
\hline SitSrc & Site source & BEIDMS & $\begin{array}{l}\text { B echtel N evada Environmental I ntegrated D ata M anagement System (BEIDM S) Oracle } \\
\text { database record. }\end{array}$ & \\
\hline SitSrc & Site source & BM & Binocular M icroscope (B M) record. & \\
\hline SitSrc & Site source & fct_chr & Fracture-characteristic (fct_chr) record. & \\
\hline SitSrc & Site source & FN & Field notes (FN) record. & \\
\hline SitSrc & Site source & hyd_pty & Hydraulic-property (hyd_pty) record. & \\
\hline SitSrc & Site source & Implied & Implied by sequence or other indication of hole. & \\
\hline SitSrc & Site source & LANL & Los A lamos National Laboratory (LA NL) record. & \\
\hline SitSrc & Site source & LLNL & Lawrence L ivermore N ational L aboratory (LLNL) record. & \\
\hline SitSrc & Site source & Ith_dsc & Lithologic-description (Ith_dsc) record. & \\
\hline SitSrc & Site source & NWIS & USGS NW IS record. & \\
\hline SitSrc & Site source & RB & $\begin{array}{l}\text { Redbook (RB) sites listed in the R aytheon Services N evada (RSN) NTS D rilling and M ining } \\
\text { Summary (last updated 12-31-90) and previously in the Fenix and Scission of Nevada N TS } \\
\text { D rilling and M ining Summary (last updated 6-30-89; formerly Fenix and Scisson, Inc.). } \\
\text { B oth summaries were referred to as the Redbook. }\end{array}$ & \\
\hline SitSrc & Site source & rck_pty & Rock-property (rck_pty) record. & \\
\hline SitSrc & Site source & rck_smp & Rock-sample (rck_smp) record. & \\
\hline SitSrc & Site source & TS & Thin section (TS) record. & \\
\hline Status & Status & - & Status of site data. & \\
\hline Status & Status & $\mathrm{A}$ & U nique LANL site. & \\
\hline Status & Status & B & Included in BEIDM S Database, but not listed in printed R edbook. & \\
\hline Status & Status & C & N evada State Plane or U niversal Transverse M ercator Coordinates available. & \\
\hline Status & Status & G & General (approximate) coordinates available. & \\
\hline Status & Status & $\mathrm{H}$ & Hole name conflict. & \\
\hline Status & Status & I & Implied by sequence or other indication of hole. & \\
\hline Status & Status & $\mathrm{L}$ & Unique L L N L site. & \\
\hline Status & Status & M & M ultiple completion intervals exist for hole or duplicate site. & \\
\hline Status & Status & $\mathrm{N}$ & Site established in USGS NWIS database. & \\
\hline Status & Status & $\mathrm{R}$ & Listed in printed Redbook, but not included in BEIDM S D atabase. & \\
\hline Status & Status & $\mathrm{S}$ & Hole segment. & \\
\hline Status & Status & U & Spatial $(x-y-z)$ coordinates unavailable for hole. & \\
\hline NTSA reaN meSrt & NTS area name sort & - & N umber assigned to initially sort this data set. & \\
\hline
\end{tabular}


Table F1. Description of Site-Characteristic Database field contents.-Continued

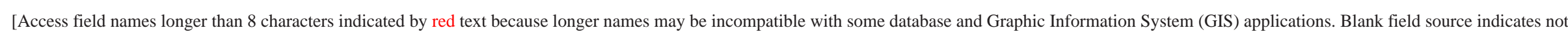

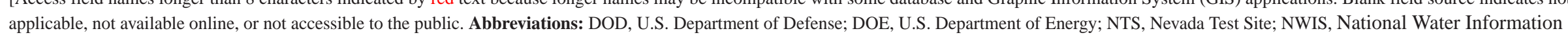
System; USGS, U.S. Geological Survey; ft, foot; - , not applicable]

\begin{tabular}{|c|c|c|c|c|}
\hline Access field name & Excel field name & Field code & Field explanation & Field source \\
\hline CmbHIN meSrt & $\begin{array}{l}\text { Combination hole name } \\
\text { sort }\end{array}$ & - & $\begin{array}{l}\text { Combined hole name field; necessary because not all sites have a USGS hole name } \\
\text { designation. Entries are listed in bold type where sites are located in areas other than the } \\
\text { hole name implies. }\end{array}$ & \\
\hline BINUGTA & UGTA BIN & - & $\begin{array}{l}\text { Underground Test A rea (UGTA) Project B orehole Index N umber (BIN) listed in the Borehole } \\
\text { Site A tlas in the Central Data R epository (CDR) currently maintained by Stoller-N avarro } \\
\text { Joint Venture (SNJV). }\end{array}$ & \\
\hline MHNLANL & LANL master hole name & - & Los A lamos N ational L aboratory (LA NL) hole name. & \\
\hline OHNLANL & LANL other hole name & - & Former or other LA NL hole names. & \\
\hline MHNLLNL & LLNL master hole name & - & Lawrence Livermore National L aboratory hole name. & \\
\hline OHNLLNL & L LNL other hole name & - & Former or other L L N L hole names. & \\
\hline RedB kA reaPg & $\begin{array}{l}\text { Printed Redbook AREA/ } \\
\text { PAGE } \\
\end{array}$ & - & $\begin{array}{l}\text { A rea and page listed in most recent available printed edition (12/31/1990) of the RSN NTS } \\
\text { Drilling and M ining Summary. }\end{array}$ & \\
\hline RedBkOrd & Printed Redbook order & - & Order site listed in RSN NTS Drilling and M ining Summary. & \\
\hline RedB kHleNo & \begin{tabular}{|c|} 
Printed Redbook [Raytheon \\
Services N evada N evada \\
Test Site Drilling $\&$ \\
M ining Summary HOLE \\
NU M BER $(12 / 31 / 1990)]$
\end{tabular} & - & $\begin{array}{l}\text { The Redbook hole number (HOLE NUM BER) exactly as listed in the RSN NTS Drilling and } \\
\text { M ining Summary. }\end{array}$ & \\
\hline CIntStal dBEIDM S & $\begin{array}{l}\text { Redbook subset [B echtel } \\
\text { N evada B EIDM S } \\
\text { database CLIENT } \\
\text { STATION ID } \\
(02 / 15 / 2006)] \\
\end{array}$ & - & $\begin{array}{l}\text { The case-sensitive hole number (Bechtel's CLIENT_STATION_ID) exactly as stored in } \\
\text { the Redbook subset of the B echtel Environmental Integrated D ata M anagement System } \\
\text { (BEIDM S) Oracle database. }\end{array}$ & \\
\hline SegN meBEIDM S & $\begin{array}{l}\text { BEIDMS SEGMENT } \\
\text { NAME }\end{array}$ & - & $\begin{array}{l}\text { The hole segment name (SEGM ENT_NAME), as stored in the Redbook subset of B echtel's } \\
\text { BEIDM S database. }\end{array}$ & \\
\hline StaldBEIDMS & BEIDM S STATION ID & - & $\begin{array}{l}\text { The upper-cased hole number (STATION_ID) as stored in the Redbook subset of B echtel's } \\
\text { BEIDM S database. }\end{array}$ & \\
\hline SrtOrdBEIDMS & BEIDM S SORT ORDER & - & $\begin{array}{c}\text { The sort order (SORT_ORDER) number stored in the Redbook subset of Bechtel's BEIDMS } \\
\text { database. This number sorts the data in the same order as the printed RSN Redbook. }\end{array}$ & \\
\hline StaSeqBEIDM S & BEIDM S STATION SEQ & - & $\begin{array}{l}\text { The unique number (STATION_SEQ) stored in the Redbook subset of Bechtel's BEIDM S } \\
\text { database. }\end{array}$ & \\
\hline RecOwnBEIDMS & $\begin{array}{l}\text { BEIDM S RECORD } \\
\text { OWNER }\end{array}$ & - & $\begin{array}{l}\text { The record owner (RECORD_OW NER) stored in the Redbook subset of Bechtel's BEIDM S } \\
\text { database. REDBOOK designates sites from the Redbook subset of BEIDM S. }\end{array}$ & \\
\hline
\end{tabular}


Table F1. Description of Site-Characteristic Database field contents.-Continued

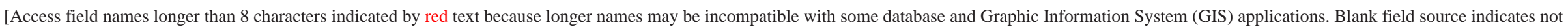

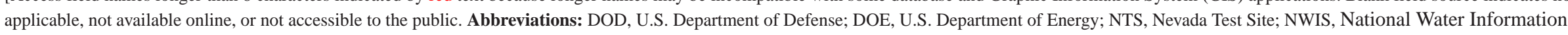
System; USGS, U.S. Geological Survey; ft, foot; -, not applicable]

\begin{tabular}{|c|c|c|c|c|}
\hline Access field name & Excel field name & Field code & Field explanation & Field source \\
\hline NVLogNo & Nevada Log number & - & $\begin{array}{l}\text { Well D riller's R eport number assigned by the Nevada Division of Water Resources (State } \\
\text { Engineer). }\end{array}$ & \\
\hline NVPmtNo & Nevada Permit number & - & Water Use Permit number issued by the N evada Division of Water R esources (State Engineer). & \\
\hline HydA rea & Hydrographic area & - & $\begin{array}{l}\text { The first three characters represent the hydrographic area and the fourth character represents } \\
\text { the hydrographic subarea. For example: [159 - Yucca Flat; } 160 \text { - Frenchman Flat; 227A } \\
\text { - Fortymile Canyon, J ackass Flats; and 227B - Fortymile Canyon, B uckboard M esa]. A } \\
\text { complete list of codes is included in the dsc_hyd_areas table in the nts_usgs_dbs database } \\
\text { (appendix F). }\end{array}$ & \\
\hline LocalNo & Local number & - & Township, range, section, section quarters, and sequence number. & \\
\hline TopoQuad & Topographic quadrangle & - & Name of topographic quadrangle. & \\
\hline $\mathrm{M}$ apScl & M ap scale & - & Scale of topographic quadrangle. & \\
\hline $\mathrm{M}$ apScl & M ap scale & 24000 & 7.5-minute quadrangles $[1: 24,000]$. & \\
\hline $\mathrm{M}$ apScl & M ap scale & 62500 & 15-minute quadrangles $[1: 62,500]$. & \\
\hline $\mathrm{M}$ apScl & M ap scale & 100000 & 30- by 60 -minute (or 1-degree) quadrangle [1:100,000]. & \\
\hline $\mathrm{M} \mathrm{apScl}$ & M ap scale & 250000 & 1- by 2-degree \{or A M S (U .S. A rmy M ap Service) \} quadrangles [1:250,000]. & \\
\hline HleTyp & Hole type & - & Type of vertical or horizontal drilling or excavation. & \\
\hline HleTyp & Hole type & B orehole & Vertical surface location; includes wells and vertical test holes. & \\
\hline HleTyp & Hole type & Crater & Vertical surface location. & \\
\hline HleTyp & Hole type & Drift & H orizontal underground location; includes tunnels and horizontal test holes. & \\
\hline HleTyp & Hole type & $\begin{array}{l}\text { Multiple } \\
\text { Wells }\end{array}$ & M ultiple wells. & \\
\hline HleTyp & Hole type & Outcrop & Surface location. & \\
\hline HleTyp & Hole type & Shaft & Vertical surface location. & \\
\hline HleTyp & Hole type & Spring & Spring. & \\
\hline HleTyp & Hole type & Streambed & Steambed. & \\
\hline HleTyp & Hole type & Surface & Surface location. & \\
\hline HleTyp & Hole type & Trench & Horizontal surface location. & \\
\hline HleTyp & Hole type & Unknown & Hole type not known. & \\
\hline TnlDftConSta & $\begin{array}{l}\text { Tunnel or drift construction } \\
\text { station }\end{array}$ & - & $\begin{array}{l}\text { Construction station at collar location (portal opening), for tunnels and drifts (i.e. - } 9+17 \text { is } 917 \\
\text { feet; } 10+72,195 \text { ' is a } 195 \text { feet hole at the } 1,072 \text { feet station; etc.). }\end{array}$ & \\
\hline ConStaRmk & $\begin{array}{l}\text { Construction station } \\
\text { remarks }\end{array}$ & - & $\begin{array}{l}\text { Remarks concerning the portal opening (collar location), for tunnels and drifts (i.e. - In } \\
\text { U-12e.14 main drift; Alcove; Face; Invert; Lft Rib; Rt Rib; etc.). }\end{array}$ & \\
\hline NVSPE27 & $\begin{array}{l}\text { Nevada SPCS Easting } \\
\text { NAD } 27\end{array}$ & - & $\begin{array}{l}\text { N evada state plane coordinates (SPCS), Easting, central zone, in feet; North A merican Datum } \\
\text { of } 1927 \text { (NA D27). }\end{array}$ & \\
\hline
\end{tabular}


Table F1. Description of Site-Characteristic Database field contents. - Continued

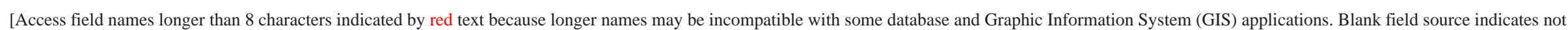

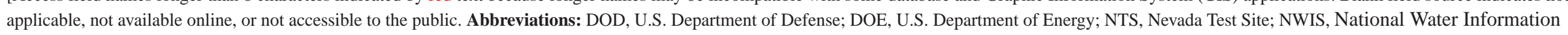
System; USGS, U.S. Geological Survey; ft, foot; -, not applicable]

\begin{tabular}{|c|c|c|c|c|}
\hline Access field name & Excel field name & Field code & Field explanation & Field source \\
\hline NV SPN 27 & $\begin{array}{l}\text { Nevada SPCS N orthing } \\
\text { NAD } 27\end{array}$ & - & $\begin{array}{l}\text { N evada state plane coordinates (SPCS), N orthing, central zone, in feet; N orth A merican Datum } \\
\text { of } 1927 \text { (NA D 27). }\end{array}$ & \\
\hline NVSPErr & SPCS error & - & SPCS error, in feet. Blank if unknown. & \\
\hline AltPorOpn29ft & $\begin{array}{l}\text { A ltitude at portal opening } \\
\text { NGVD29 (ft) }\end{array}$ & - & $\begin{array}{l}\text { A ltitude at the collar location of the portal opening, for tunnels and drifts; in feet above mean } \\
\text { sea level; N ational Geodetic Vertical Datum of } 1929 \text { (NGV D 29). }\end{array}$ & \\
\hline BngPorOpnDeg & $\begin{array}{l}\text { B earing from portal } \\
\text { opening (degrees) }\end{array}$ & - & $\begin{array}{l}\text { B earing from the portal opening, for tunnels and drifts; in degrees, minutes, and seconds } \\
\text { or decimal degrees (i.e. - S0720958W is South, } 72 \text { degrees, } 9 \text { minutes, } 58 \text { seconds West; } \\
\text { N } 0325529 \mathrm{E} \text { is North, } 32 \text { degrees, } 55 \text { minutes, } 29 \text { seconds East; N 052.75W is N orth } 52 \text { and } \\
\text { three-quarter degrees West; etc.) }\end{array}$ & \\
\hline IncPorOpnDeg & $\begin{array}{l}\text { Inclination from portal } \\
\text { opening (degrees) }\end{array}$ & - & $\begin{array}{l}\text { Inclination from the portal opening, for tunnels and drifts; in degrees, minutes, and seconds or } \\
\text { decimal degrees (i.e. - } 0045825 \text { is a hole } 4 \text { degrees, } 58 \text { minutes, } 25 \text { seconds above horizontal; } \\
2700000 \text { is a vertical hole below horizontal; } 0900000 \text { is a vertical hole above horizontal; } \\
0000000 \text { and } 1800000 \text { are horizontal holes; } 0150000 \text { and } 1650000 \text { are holes } 15 \text { degrees up } \\
\text { (above horizontal); } 3150000 \text { and } 2250000 \text { are holes } 45 \text { degrees down (below horizontal); } \\
356.5 \text { is a hole } 3 \text { and one-half degrees below horizontal; } 170.25 \text { is } 9 \text { and three-quarter } \\
\text { degrees above horizontal; etc.). Inclinations are linked to bearings, so values near horizontal } \\
\text { for holes bearing north or east would be added to zero for holes inclined above horizontal } \\
\text { and subtracted from } 360 \text { for holes bel ow horizontal; conversely, values near horizontal for } \\
\text { holes bearing south or west would be subtracted from } 180 \text { for holes inclined above horizontal } \\
\text { and added to } 180 \text { for holes bel ow horizontal. }\end{array}$ & \\
\hline AltL ndSur29ft & $\begin{array}{l}\text { A ltitude of land surface } \\
\text { NGV D29 (ft) }\end{array}$ & - & $\begin{array}{l}\text { A Ititude of land surface within a reasonable proximity of the site; in feet above mean sea level; } \\
\text { N ational Geodetic Vertical D atum of } 1929 \text { (N G V D 29). This is an average of the surrounding } \\
\text { ground-surface el evation. If the original surface has been altered, estimate the altitude based } \\
\text { on nearby unal tered terrain. }\end{array}$ & \\
\hline AltM th & Altitude method & - & M ethod used to determine altitude of land surface. & \\
\hline AltM th & Altitude method & A & A ltimeter. & \\
\hline AltM th & A ltitude method & $\mathrm{D}$ & Differentially-corrected G lobal Positioning System (DGPS). & \\
\hline AltM th & Altitude method & G & Global Positioning System (GPS). & \\
\hline AltM th & Altitude method & $\mathrm{I}$ & Interferometric Synthetic A perture Radar (IfSA R), airplane. & \\
\hline AltM th & Altitude method & 」 & Light Detection A nd Ranging (LiDA R), airplane. & \\
\hline AltM th & Altitude method & L & L evel or other surveying method. & \\
\hline AltM th & Altitude method & M & $\begin{array}{l}\text { Interpolated from topographic map [report accuracy as }+/- \text { one-half the contour interval (or } \\
\text { supplementary contour interval) specified on the quadrangle]. }\end{array}$ & \\
\hline AltM th & A ltitude method & $\mathrm{N}$ & Interpolated from digital elevation model (DEM). & \\
\hline AltM th & Altitude method & $\mathrm{R}$ & Reported. & \\
\hline
\end{tabular}


Table F1. Description of Site-Characteristic Database field contents.-Continued

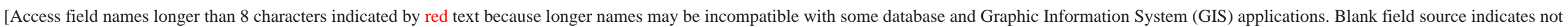

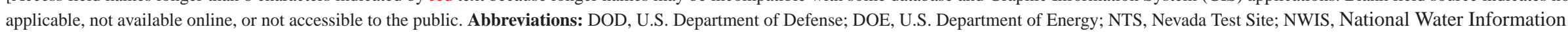
System; USGS, U.S. Geological Survey; ft, foot; -, not applicable]

\begin{tabular}{|c|c|c|c|c|}
\hline Access field name & Excel field name & Field code & Field explanation & Field source \\
\hline AltM th & Altitude method & U & Unknown. & \\
\hline AltAcc & Altitude accuracy & - & A ltitude accuracy; in feet (decimal values for accuracies less than 1 foot). & \\
\hline AltAcc & Altitude accuracy & U & Unknown. & \\
\hline SitCmpDt & Site completion date & - & Date hole construction completed. & \\
\hline HleD thft & Hole depth (ft) & - & $\begin{array}{l}\text { Hole depth; in feet below land surface for boreholes and shafts; in feet from portal opening for } \\
\text { tunnels and drifts. }\end{array}$ & \\
\hline A gyCdUSGSNWIS & NW IS agency code & USGS & $\begin{array}{l}\text { U SGS NW IS code to indicate the reporting agency. M ost sites currently populated in the site- } \\
\text { characteristic database are assigned as USGS. A complete list of codes is included in the } \\
\text { dsc_agency_codes_all_st table (appendix F). }\end{array}$ & \\
\hline SitIDN oU SGSN WIS & $\begin{array}{l}\text { NW IS site identification } \\
\text { number }\end{array}$ & - & USGS NW IS site identification number. & \\
\hline SitIDN oU SGSNWIS & $\begin{array}{l}\text { NW IS site identification } \\
\text { number }\end{array}$ & - & $\begin{array}{l}\text { D ownstream order numbers are assigned for surface-water, on-stream, sites. The first two digits } \\
\text { of the station number indicate the part or major drainage system formerly used for USGS } \\
\text { Water-Supply Papers entitled "Surface Water Supply of the U nited States" and the remaining } \\
\text { digits indicate the downstream order within the part. This site number is left-justified. } \\
\text { A Ithough downstream identification numbers have been converted to a variable length } \\
\text { format, with up to } 14 \text { digits available, } 8 \text { digits are normally assigned. }\end{array}$ & \\
\hline SitIDN oU SGSN WIS & $\begin{array}{l}\text { NW IS site identification } \\
\text { number }\end{array}$ & - & $\begin{array}{l}\text { N umbering system for sites on open water bodies, off-channel sites, wells, springs, etc., } \\
\text { is based on the grid system of latitude and longitude. A Ithough this number is initially } \\
\text { determined from the best known latitude/longitude location, plus a 2-digit sequence number } \\
\text { for the number of sites located at those coordinates, it retains no locational relevance once } \\
\text { the site is created in the database. The overall designation consists of } 15 \text { digits. The values of } \\
\text { latitude and longitude are updated as better coordinates become available, and should always } \\
\text { be used for locating sites or plotting locations. }\end{array}$ & \\
\hline CreateDtU SGSN WIS & $\begin{array}{l}\text { Date site created in USGS } \\
\text { NWIS Sitefile }\end{array}$ & - & $\begin{array}{l}\text { Date site established in the shared Sitefile of the USGS N WIS database; as yyyymmddhhmmss } \\
\text { (4-digit year; 2-digit month; 2-digit day; 2-digit hour; 2-digit minute; 2-digit second). }\end{array}$ & \\
\hline L at27 & Latitude NA D 27 & - & $\begin{array}{l}\text { Latitude; in degrees, minutes, and seconds [two digits are available for decimal seconds]; North } \\
\text { A merican D atum of } 1927 \text { (NA D27). }\end{array}$ & \\
\hline Lng27 & Longitude NAD 27 & - & $\begin{array}{l}\text { L ongitude; in degrees, minutes, and seconds [two digits are available for decimal seconds]; } \\
\text { N orth A merican Datum of } 1927 \text { (NA D 27). }\end{array}$ & \\
\hline LocM th & Location method & - & M ethod used to determine latitude and longitude coordinates. & \\
\hline LocM th & L ocation method & C & Calculated from land net. & \\
\hline LocM th & L ocation method & $\mathrm{D}$ & Differentially-corrected Global Positioning System (DGPS). & \\
\hline
\end{tabular}


Table F1. Description of Site-Characteristic Database field contents.-Continued

[A ccess field names longer than 8 characters indicated by red text because longer names may be incompatible with some database and G raphic Information System (GIS) applications. Blank field source indicates not applicable, not available online, or not accessible to the public. Abbreviations: DOD, U.S. Department of Defense; DOE, U.S. Department of Energy; NTS, N evada Test Site; NWIS, N ational Water Information System; USGS, U.S. Geological Survey; ft, foot; -, not applicable]

\begin{tabular}{|c|c|c|c|c|}
\hline Access field name & Excel field name & Field code & Field explanation & Field source \\
\hline LocM th & L ocation method & G & $\begin{array}{l}\text { Global positioning system (GPS), uncorrected [Standard Positioning Service (SPS) and Precise } \\
\text { Positioning Service (PPS)]. }\end{array}$ & \\
\hline LocM th & L ocation method & $\mathrm{L}$ & L ong-range navigation (L oran) system. & \\
\hline LocM th & Location method & M & Interpolated from map. & \\
\hline LocM th & Location method & $\mathrm{N}$ & Interpolated from digital map. & \\
\hline LocM th & L ocation method & $\mathrm{R}$ & Reported. & \\
\hline LocM th & L ocation method & $\mathrm{S}$ & Transit, theodolite, or other surveying method. & \\
\hline LocM th & Location method & U & Unknown. & \\
\hline LOCACC & L ocation accuracy & - & Accuracy of latitude and longitude coordinates. & \\
\hline LOCACC & L ocation accuracy & $\mathrm{H}$ & Hundredth second. & \\
\hline LOCACC & Location accuracy & 1 & Tenth second. & \\
\hline LOCACC & L ocation accuracy & 5 & Half second. & \\
\hline LOCACC & L ocation accuracy & $\mathrm{S}$ & Second. & \\
\hline LOCACC & L ocation accuracy & $\mathrm{R}$ & Three seconds. & \\
\hline LOCACC & L ocation accuracy & $\mathrm{F}$ & Five seconds. & \\
\hline LOCACC & L ocation accuracy & $T$ & Ten seconds. & \\
\hline LOCACC & Location accuracy & M & Minute. & \\
\hline LOCACC & L ocation accuracy & U & Unknown. & \\
\hline DecL at83 & Decimal latitude NA D83 & - & $\begin{array}{l}\text { Latitude, in decimal degrees [automatically generated by the NW IS system software]; N orth } \\
\text { A merican Datum of } 1983 \text { (NAD 83). }\end{array}$ & \\
\hline DecLng83 & Decimal longitude NAD 83 & - & $\begin{array}{l}\text { L ongitude, in decimal degrees [automatically generated by N WIS system software]; North } \\
\text { A merican D atum of } 1983 \text { (NAD 83). }\end{array}$ & \\
\hline UTME 27m & $\begin{array}{l}\text { UTM Easting NAD } 27 \\
\text { (meters) }\end{array}$ & - & $\begin{array}{l}\text { Universal Transverse M ercator coordinates, Easting, zone 11, in meters; N orth A merican } \\
\text { Datum of } 1927 \text { (NAD 27). }\end{array}$ & \\
\hline UTMN 27m & $\begin{array}{l}\text { UTM Northing NAD } 27 \\
\text { (meters) }\end{array}$ & - & $\begin{array}{l}\text { Universal Transverse M ercator coordinates, N orthing, zone 11, in meters; N orth A merican } \\
\text { Datum of } 1927 \text { (NAD 27). }\end{array}$ & \\
\hline UTMErr & UTM error & - & UTM error, in meters. Blank if unknown. & \\
\hline Rmk & Remarks & - & Pertinent remarks pertaining to the site characteristics. & \\
\hline DtRcdLstUpd & Date record last updated & - & $\begin{array}{l}\text { Date of data entry (compiled into electronic format) is listed if a row of record has not been } \\
\text { modified. The date of last (most recent) update is listed if a row of record has been modified. } \\
\text { This date does not indicate which columns of data have been modified; only that records } \\
\text { have been updated within a particular row. Dates are listed as yyyymmdd (4-digit year; } \\
\text { 2-digit month; 2-digit day). }\end{array}$ & \\
\hline URLAdr & URL address & - & Link to online website and database. & \\
\hline
\end{tabular}


Digitally Available Interval-Specific Rock-Sample Data Compiled from Historical Records, Nevada Test Site, Nevada

This page left intentionally blank 
For more information contact:

Director, Nevada Water Science Center

U.S. Geological Survey

2730 N. Deer Run Road

Carson City, Nevada 89701

http://nevada.usgs.gov 


\section{ญू}

5

를 